\title{
CRIME, SENSATION, AND EMPIRE
}

Madeleine Smith and the Tichborne Claimant in Australia, circa $1857-1900$

\author{
By \\ Thomas James Boyd
}

\author{
A thesis \\ submitted to Victoria University of Wellington \\ in fulfilment of the requirements for the degree of \\ Master of Arts \\ in History
}

Victoria University of Wellington

2021 



\begin{abstract}
The 1857 criminal trial of Madeleine Smith for the murder of Pierre Emile L'Angelier became a cause célèbre throughout the British world. Enmeshed with scandal and speculation, it involved a secret affair between a young upper middle-class Glasgow woman and her older foreign lover of lower social standing; accusations of arsenic poisoning that led to his demise; erotic love letters that were read out in court; and an inconclusive-and uniquely Scottishverdict of 'not proven'. In 1866, a butcher under the name of Thomas Castro from Wagga Wagga, New South Wales, claimed to be the heir to an ancient English baronetcy: the Tichborne estates. Similarly described as its own cause célèbre, the Tichborne baronetcy case spanned two long-running civil and criminal trials and led to a political movement in Britain that continued to take aim at political, legal, and religious institutions long after the trials had ended, in 1874.

Although the crimes at the centre of the two cases were incongruous, both Madeleine Smith and the Tichborne Claimant ignited significant public debate over criminal procedures, class, gender, and identity. Smith's case played a key role in the development of 'sensation' journalism and literature centred on the violent propensities that lurked beneath the seemingly respectable and repressive Victorian social code, while the Tichborne Claimant's case confronted Britons with anxieties around the definition of 'respectability' and the homecoming of expatriates from the colonies.
\end{abstract}

While coverage of the cases has been well-documented within Britain, less scholarly attention has been paid to their pervasive coverage in the colony of Australia. Both cases were major news items in the colonial press, as updates on the trials were sourced from British media outlets and published in local newspapers almost daily. So pervasive was the coverage that gossip and misinformation surrounding the two cases spread throughout Australia and, to a lesser extent, New Zealand, as speculation surrounded Smith's later whereabouts over the late nineteenth century and questions about the Tichborne Claimant's identity lingered.

By examining the widespread coverage of the cases in Australia, this work explores how the cases harnessed the communicative powers of the press and stirred sensation in and outside of Britain. Both cases played a role in forging British-Australian transnational identities in the colonies, as Australian newspapers lent their unique voices to associated British metropolitan discussions and weighed in on the respective trial verdicts. With Smith embodying the perceived exodus of undesirable migrants to Australia and the Tichborne Claimant representing colonial life being brought back to the British metropole, Australian newspapers also used the cases to confront the way British metropolitan newspapers wrote about the colony. Fixation on the appearances, manners, and movements of Smith and the Tichborne Claimant, and the crimes with which they were implicated, meant that the Australian newspaper press became an arena for long-standing and far-reaching debate about class, social respectability, gender, sexuality, criminality, and colonial justice. 


\section{Contents}

Abstract




\section{Acknowledgements}

I owe my greatest thanks to my supervisor, Dr. Valerie Wallace, whose guidance, expertise, and sound reassurance have made this journey a rewarding one. Thank you for imparting to me an earnest passion for the past and for always encouraging me to do my best.

Sincere thanks must go to all the staff and postgraduate students at Victoria University of Wellington's History Programme. With the impacts of COVID-19 still lingering, the past year has been a difficult one at times, but your support, feedback, and warmth have made me feel at home. I owe particular thanks to Prof. Charlotte Macdonald and Dr. Arini Loader, my honours coordinators at Victoria University of Wellington, for helping me grow as an historian.

I am very grateful to the staff at Te Pātaka Kōrero, Victoria University of Wellington's library, the National Library of Australia, the State Library of New South Wales, and the State Library of Victoria for their patience and dedication to assisting me in my research, whether in person or from afar. I am immensely thankful to Doug Moncur for his generous insights into and shared enthusiasm for the project.

I would not have been able to undertake this research without the financial support provided by the Royal Society of New Zealand Te Apārangi Marsden Fund. The Marsden Fund also provided funding which enabled me to present on aspects of this project at the Australia and New Zealand Law and History Society Conference. The experience was a thought-provoking and moving one.

Finally, I would like to thank my family for being there for me through it all. I could not have done it without your love, kindness, and support. This thesis is dedicated to my grandfather, Bill, for showing an unwavering interest in my work and for always believing in me. 


\section{List of Abbreviations}

$\begin{array}{ll}\text { NSWPD } & \text { New South Wales Parliamentary Debates } \\ \text { OMA } & \text { Ovens and Murray Advertiser } \\ \text { SMH } & \text { Sydney Morning Herald } \\ \text { VPD } & \text { Victoria Parliamentary Debates } \\ \text { WWA } & \text { Wagga Wagga Advertiser } \\ \text { WWE } & \text { Wagga Wagga Express }\end{array}$




\section{List of Figures}

Figure 1: 'The Tichborne Claimant in Wagga Wagga', Illustrated Sydney News, 17 March 1883, p.16.

Figure 2: Photograph of Tichbourne [sic] Trial oil painting by Nathan Hughes of London, 1883, Ref. No. H96.160/285, State Library of Victoria (accessed on State Library of Victoria website, http://handle.slv.vic.gov.au/10381/53218, 6 April 2021).

Figure 3: 'Faithful Portrait, from Daguerreotype, of Miss Madeline Smith', from Caroline Harper Dexter, Miss Madeline Smith: The Glasgow Poisoning Case. A Tale of "Scotch Mist"ery, Entitled Emile and Madeline; or Love and Murder (Melbourne: Melbourne Herald Office, 1857), p.2.

Figure 4: 'The Beggar's Petition', from Judy, or the London Serio-Comic Journal, 24 April 1872, in Douglas Woodruff, The Tichborne Claimant: A Victorian Mystery (London: Hollis and Carter, 1957), p.227.

Figure 5: 'The End of the Tichborne Case', Melbourne Punch, 25 December 1873, p.6.

Figure 6: 'Sir Roger Tichborne' and 'William Creswell' [sic], South Australian Chronicle, 29 December 1894, p.21. 


\section{Introduction}

On the evening of Sunday 22 March 1857, Pierre Emile L'Angelier, a shipping clerk from Jersey, left his Glasgow lodgings after an abrupt return from Bridge of Allan, visited a friend's house near Blythswood Square, and then vanished for five hours. He returned to his abode in the early hours of Monday morning, vomiting violently and in agony. By 11A.M., he was pronounced dead. ${ }^{1}$ One of his supervisors discovered amongst his belongings a myriad of letters signed by 'Mimi', revealing L'Angelier's clandestine love affair with Madeleine Smith, a 21year-old socialite hailing from a prominent dynasty of Glasgow architects. In her final letter, which L'Angelier received on 21 March, Smith had expressed her desire to meet him in Glasgow 'tomorrow night - same hour and arrangement'. ${ }^{2}$ Under the suspicion that L'Angelier's death was not a natural one, a post-mortem was carried out, which found 82 grains of arsenic in his body. ${ }^{3}$ Further suspicion fell on Smith when it was discovered that she had recently purchased large quantities of arsenic from several chemists (supposedly to kill rats at the family home), and that she had, after hearing about L'Angelier's death, mysteriously disappeared to board a ship for Helensborough. ${ }^{4}$ Not long after she confided to her fiancée, William Minnoch, that she had purchased arsenic for cosmetic purposes, Smith was arrested and charged with the murder of L'Angelier on 31 March. $^{5}$

The trial of Madeleine Smith became a public sensation in Britain. Variously described as the 'trial of the century', the case subverted notions of Victorian respectability, ignited fervent discussion in Britain over its uniquely Scottish verdict of 'not proven', and brought issues of class, gender, sexuality, and identity to the forefront of public debate. ${ }^{6}$

\footnotetext{
${ }^{1}$ Eleanor Gordon and Gwyneth Nair, Murder and Morality in Victorian Britain: The Story of Madeleine Smith (Manchester: Manchester University Press, 2010), p.120; Douglas MacGowan, The Strange Affair of Madeleine Smith: Victorian Scotland's Trial of the Century (Edinburgh: Mercat Press, 2007), p.74.

${ }^{2}$ MacGowan, Strange Affair, p.73.

${ }^{3}$ William W. J. Knox, The Lives of Scottish Women: Women and Scottish Society 1800-1980 (Edinburgh: Edinburgh University Press, 2006), p.62.

${ }^{4}$ Gordon and Nair, Murder and Morality, p.120; G. Lathom Browne and C. G. Stewart, Reports of Trials for Murder By Poisoning; by Prussic Acid, Strychnia, Antimony, Arsenic, and Aconitia. Including the Trials of Tawell, W. Palmer, Dove, Madeleine Smith, Dr. Pritchard, Smethurst, and Dr. Lamson, with chemical introduction and notes on the poisons used (London: Stevens and Sons, 1883), p.330.

${ }^{5}$ MacGowan, Strange Affair, p.79.

${ }^{6}$ Sara Murphy, 'Inadmissible Evidence: The Trials of Madeleine Smith and Collins's The Law and the Lady', Victorian Literature and Culture, Vol. 44, no. 1, 2016, p.165; see also MacGowan, Strange Affair.
} 
Nine years later, in 1866, another legal cause célèbre caught the attention of the British public: that of a butcher under the name of Thomas Castro from Wagga Wagga, New South Wales, who claimed to be Sir Roger Charles Doughty Tichborne, the heir to an ancient English baronetcy. Tichborne was believed to have drowned in a shipwreck - the Belle-off the coast of Brazil in 1854. The death of Roger Tichborne's father, James, in 1862 meant that the baronetcy, inheritable only by male heirs, was passed to Roger's 'dissipated and reckless' younger brother, Alfred. ${ }^{7}$ While Alfred sought legal help to declare his older brother formally dead, his mother, Henriette, contacted a missing persons agency and placed advertisements in newspapers across Britain and Australia, offering a reward for information about Roger's fate. ${ }^{8}$ By 1865 , it was rumoured that some passengers and crew of the Belle had been picked up by a vessel bound for Melbourne, and thus Henriette employed Arthur Cubitt of the 'Missing Friends Office' in Sydney to aid her in the search in May $1865 .{ }^{9}$ Cubbit, a specialist in tracking down former convicts, placed advertisements across the pages of Australian newspapers, including the Argus, the Sydney Morning Herald, the Sydney Mail, and the Empire, and offered a 'handsome' and 'most liberal' reward for information on Roger's whereabouts. ${ }^{10}$

As the search for Roger extended across the Tasman Sea, it was in Wagga Wagga that William Gibbes, a solicitor, corroborated the advertisements with the passing comments of one of his clients, Castro, who had mentioned being involved in a shipwreck, claimed to have properties in England, and smoked from a pipe with the initials 'R.C.T' on it. ${ }^{11}$ Henriette convinced Castro to meet her in Paris, where in January 1867, she immediately recognised him as Roger. ${ }^{12}$ However, the wider Tichborne family, who had a strained relationship with the French-born Henriette, remained doubtful, and 'unanimously' declared that 'neither in height, voice, figure, manner, or education' did Castro resemble their long lost relative, nor was he able

\footnotetext{
${ }^{7}$ Christopher Kent, 'Victorian Self-Making, or Self-Unmaking? The Tichborne Claimant Revisited', Victorian Review, Vol. 17, no. 1, 1991, p.18; Max Everest-Phillips, 'The 1871 'Tichborne Claimant' medal and the forging of Australia's identity', Journal of the Numismatic Association of Australia, Vol. 24, 2013, p.5.

${ }^{8}$ Everest-Phillips, 'The 1871 'Tichborne Claimant' medal', pp.5-6.

9 There was also some speculation that a 'Roger C. Tichborne' was stationed in the 3rd Regiment of the Waikato Militia in New Zealand during the wars of colonisation. See John Dettmer Dodds Jackson, Sir Roger Tichborne Revealed!: The Discovery of Sir Roger Charles Doughty Tichborne alias Edward Caleb Souper, secretary to Lady Ogle of Withdeane Court near Brighton, Sussex, England, and his confederates (Sydney: H. Garforth, Printer, 1885), p.26.

${ }^{10}$ SMH, 26 July 1865, p.1; 29 July 1865, p.1; 2 August 1865, p.1; 5 August 1865, p.1; Argus, 29 July 1865, p.7; 2 August 1865, p.7; 5 August 1865, p.7; 9 August 1865, p.7; Empire, 4 August 1865, p.1; Sydney Mail, 5 August 1865, p.1. For discussion on Cubitt, see Rohan McWilliam, The Tichborne Claimant: A Victorian Sensation (London: Hambledon Continuum, 2007), p.14.

${ }^{11}$ Jackson, Sir Roger Tichborne Revealed!, pp.30-32; Janet C. Myers, Antipodal England: Emigration and Portable Domesticity in the Victorian Imagination (Albany:State University of New York Press, 2009), p.97.

${ }^{12}$ Kent, 'Victorian Self-Making', p.18; Jackson, Sir Roger Tichborne Revealed!, p.33; Myers, Antipodal England, p.98.
} 
to recognise any one of them, as The Times reported. ${ }^{13}$ As such, Castro sought to prove his identity in court.

Compared to the haste of the Madeleine Smith case, the Tichborne affair was lengthy and convoluted, spanning two long-lasting (civil and criminal) trials, encompassing numerous affidavits from across the British world, and stirring a highly charged socio-political movement. Despite their differences, the Smith and Tichborne cases share some important commonalities that warrant examination. Both were highly sensationalised in the press and followed with incessant interest by the British public. They occurred at a time when criminal law had become a public spectacle, evidenced by the growth of mass gatherings in and outside of courtrooms, widespread media coverage, and novels and popular literature centred on crime and criminals. ${ }^{14}$ Both trials played a crucial role in fashioning the mid-nineteenth-century surge of public interest in the courtroom, and that fashioning rested strongly on debates about class and social respectability. Whereas Smith hailed from an upper-middle-class family, the 'Claimant' was widely branded in the newspaper press as a lowly butcher. Concerns about Victorian society's cultural worshipping of criminals were evident in the coverage of both trials, and significant public attention was paid to the appearances and sexuality of the two figures.

The British newspaper press's role in broadcasting the spectacle of shame made it a valued source of inspiration for sensation writers from the mid-nineteenth century, particularly following the removal of the stamp duty in 1855 and the consequential boom in cheap newspapers. ${ }^{15}$ 'Sensation' has been defined as 'a condition of excited feeling produced in a community by some occurrence' and, in Victorian Britain, it became synonymous with the shocking, scandalous, and taboo. ${ }^{16}$ Critics derided the British public's appetite for sensation as 'degenerate' and 'unwholesome', and widely branded sensation fiction as hasty, substandard, and mass-produced. ${ }^{17}$ Despite being criticised for their literary quality, the ubiquity of midnineteenth-century sensation novels that explored the topical themes of crime, bigamy, murder,

\footnotetext{
${ }^{13}$ David Wayne Thomas, Cultivating Victorians: Liberal Culture and the Aesthetic (Philadelphia: University of Pennsylvania Press, 2004), p.87; The Times, 4 April; 1867, p.5.

${ }^{14}$ Christopher A. Casey, 'Common Misperceptions: The Press and Victorian Views of Crime', Journal of Interdisciplinary History, Vol. 41, no. 3, 2011, p.375.

15 Matthew Rubery, The Novelty of Newspapers: Victorian Fiction after the Invention of the News (Oxford: Oxford University Press, 2009), pp.64-65.

${ }^{16}$ Michael Diamond, Victorian Sensation: Or, the Spectacular, the Shocking and the Scandalous in NineteenthCentury Britain (London: Anthem Press, 2003), pp.1-3.

${ }^{17}$ Andrew Radford, Victorian Sensation Fiction (Basingstoke: Palgrave Macmillan, 2009), pp.1-3.
} 
illegitimacy, inheritance scandals, and adultery cannot be overstated. ${ }^{18}$ Such literature could appeal to readers from all classes.

Blending reading with the increasing commodification of Victorian life, sensation novels served as objects of what Benedict Anderson calls 'print capitalism'. ${ }^{19}$ As sensation novelist Anthony Trollope wrote, they could be 'read right and left, above stairs and below, in town houses and country parsonages, by young countesses and by farmers' daughters, by old lawyers and by young students'. ${ }^{20}$ What made sensation literature so ubiquitous was that it was often difficult to confine as a genre. It entailed everything from 'penny dreadfuls', a kind of cheap serial focused on lurid crimes, criminals, and gothic horror which became widely popular among young working and lower middle-class Britons, to the more critically successful works of such authors as Trollope, Wilkie Collins, Mary Elizabeth Braddon, and Thomas Hardy. ${ }^{21}$ Through editorials, trial reports, crime reports, stories told through 'agony columns', and advertisements, newspapers - as the focus of this thesis - were the 'embryos' of sensation literature. ${ }^{22}$ Amidst the appetite for sensation, the Smith and Tichborne cases had it all: crime, ambiguity, rumour, sex, class confrontation, debates over respectability, and questions about identity.

Both the Madeleine Smith and Tichborne cases involved Australia, not least in the thematic entanglements of class and colony, but also in the way they illustrated the spread of news to the colonies and to various extents contributed to the perception of colonies as distant refuges for criminals. The Claimant's case reflected wider anxieties about the homecoming of British expatriates from the convict colony of Australia, and Smith's purported retreat to Australia and New Zealand following her trial showed how synonymous news was with the spread of gossip and misinformation.

Yet, though the Smith case and discussion surrounding it have been well-documented within Britain, less historical attention has been given to how the trial was received by Britons in the colonies, including in Australia. As Alexander Duncan Smith prefaced in a 1905

\footnotetext{
18 Ibid, p.4.

${ }^{19}$ Shu-Chuan Yan, 'Emotions, Sensations, and Victorian Working-Class Readers', The Journal of Popular Culture, Vol. 50, no. 2, p.329; Benedict Anderson, Imagined Communities: Reflections on the Origin and Spread of Nationalism (London and New York: Verso, 2006. First published in 1983), pp.34-36.

${ }^{20}$ Nicholas Shrimpton (ed.), Anthony Trollope: An Autobiography and Other Writings (Oxford: Oxford University Press, 2014), pp.137-138.

${ }^{21}$ Gavin Sutter, 'Penny Dreadfuls and Perverse Domains: Victorian and Modern Moral Panics', in Judith Rowbotham and Kim Stevenson (eds.), Behaving Badly: Social Panic and Moral Outrage - Victorian and Modern Parallels (Hampshire and Burlington: Ashgate, 2003), p.164.

${ }^{22}$ Rubery, The Novelty of Newspapers, pp.64-79.
} 
collection of evidence from the trial, "no criminal cause of modern times has more deeply absorbed the interest and attention of a whole empire' and 'formed the central if not the exclusive topic of current popular speculation'. ${ }^{23}$ Nonetheless, Duncan Smith and other early scholars of the Madeleine Smith case, including criminologist F. Tennyson Jesse, focused firmly on a Victorian British context. ${ }^{24}$ Mary Hartman analysed the case through a feminist lens in her 1973 study, suggesting that Smith was driven to murder to maintain the appearance of public respectability. ${ }^{25}$ Sheila Sullivan has also explored the entanglement of gender, criminality, and respectability surrounding the case ${ }^{26}$ Randa Helfield has paid due attention to the coverage of the case in Scotland, ${ }^{27}$ and Douglas MacGowan and Brian Jenkins have each opted for a more intricate retelling of the events as they unfolded. ${ }^{28}$ Significant for this study, Eleanor Gordon and Gwyneth Nair's comprehensive account of the case has unravelled more vivid details about Smith's life while exploring responses to her trial in the press and by contemporary observers on sex, morality, parenting, and national identity in Britain. ${ }^{29}$ Tiffany Donnelly has touched on how one Australian writer, Caroline Harper Dexter, wrote about the case, but few other accounts have assessed the trial's resonance in Australia and - to a lesser extent-New Zealand. ${ }^{30}$

Australian coverage of the Tichborne case has been afforded relatively more scholarly attention than the Smith trial, particularly in Australia, but discussion has still strongly centred on reactions within Victorian Britain. Douglas Woodruff published a seminal account of the case in 1957, which was followed by Michael Roe's 1974 examination of the 'popular feeling' that the case aroused. ${ }^{31}$ More recently, Rohan McWilliam has also explored the Tichborne case as part of a broader political and cultural movement in Britain; ${ }^{32}$ Rebecca Stern has correlated

\footnotetext{
${ }^{23}$ A. Duncan Smith (ed.), The Trial of Madeleine Smith (Sydney and Wellington: Butterworth \& Co. (Australia), Limited, 1921. First published in 1905), p.1.

${ }^{24}$ F. Tennyson Jesse (ed.), Trial of Madeleine Smith (Sydney, Wellington, and Calcutta: Butterworth \& Co. (Australia), Limited, 1927).

${ }^{25}$ Mary S. Hartman, 'Murder for Respectability: The Case of Madeleine Smith', Victorian Studies, Vol. 16, no. 4, 1973, pp.381-400. See also Gordon and Nair, pp.169-170.

${ }^{26}$ Sheila Sullivan, "'What is the Matter with Mary Jane?": Madeleine Smith, Legal Ambiguity, and the Gendered Aesthetic of Victorian Criminality', Genders, Vol. 35, 2002, pp.1-44.

${ }^{27}$ Randa Helfield, 'Poisonous Plots: Women Sensation Novelists and Murderesses of the Victorian Period', Victorian Review, Vol. 21, no. 2, 1995, pp.161-188.

${ }^{28}$ MacGowan, Strange Affair; Brian Jenkins, Madeleine Smith on Trial: A Glasgow Murder and the Young Woman Too Respectable to Convict (North Carolina: McFarland \& Company, Inc., 2019).

${ }^{29}$ Gordon and Nair, Murder and Morality.

30 Tiffany Donnelly, “Trumpery Stuff': Gender Politics in Australian Publishing, 1858', Bibliographical Society of Australia and New Zealand Bulletin, Vol. 26, no. 1, 2002, pp.29-42.

${ }^{31}$ Douglas Woodruff, The Tichborne Claimant: A Victorian Mystery (London: Hollis and Carter, 1957); Michael Roe, Kenealy and the Tichborne Cause: A Study in Mid-Victorian Populism (Melbourne: Melbourne University Press, 1974).

${ }^{32}$ McWilliam, The Tichborne Claimant.
} 
it with the British government's concerns over domestic fraud; ${ }^{33}$ David Wayne Thomas has associated the case with mid-Victorian liberal culture, ${ }^{34}$ and Robyn Annear has told the story for a mass market audience. ${ }^{35}$ Others have approached the case through literary, legal, and scientific lenses. ${ }^{36}$ Important for this thesis, Cassie Dawson and Max Everest-Phillips have connected the case to the forging of British and Australian national identities, respectively, while Roe's work has provided a strong basis for examining the extent to which a 'popular movement' occurred in Australia. ${ }^{37}$ Where this thesis departs from previous secondary literature on the case is through its examination of how Australian newspapers carried and contributed to the Tichborne sensation.

The Smith trial occurred at a time of significant demographic and social change in the colonies. The gold rushes in the Australian colonies of New South Wales and Victoria from 1851, along with the discovery of gold in New Zealand's South Island in 1852, contributed to a surge in British migration to the colonies from the late $1850 \mathrm{~s} .{ }^{38}$ Scottish migrants comprised approximately 100,000 of the 600,000 migrants that entered Australia during the 1850 s, many of whom came from Glasgow-Madeleine Smith's home — and the wider Lanarkshire county. ${ }^{39}$ In New Zealand, the influx of British migrants from 1840 was enabled by the New Zealand Company, with Scots comprising over $15 \%$ of company settlement immigrants over 1840$1852 .^{40}$ The flow of settlers broadened the trial's reach to British, and particularly Scottish, observers far from home. Much has been written on the shaping and reforming of 'Scottishness' in the colonies from the mid-nineteenth century through such means as annual festivals and

\footnotetext{
${ }^{33}$ Rebecca Stern, Home Economics: Domestic Fraud in Victorian England (Columbus: Ohio State University Press, 2008).

${ }^{34}$ Thomas, Cultivating Victorians.

${ }^{35}$ Robyn Annear, The Man Who Lost Himself: The Unbelievable Story of the Tichborne Claimant (Melbourne: The Text Publishing Company, 2002).

${ }^{36}$ See also Kent, 'Victorian Self-Making', pp.18-34; Sean Grass, The Commodification of Identity in Victorian Narrative (Cambridge: Cambridge University Press, 2019); Sara Murphy, "No Two Men Were Ever Alike Within": The Tichborne Trial, The Lord Chief Justice, and The Narration of Identity', Law, Culture and the Humanities, Vol. 13, no. 2, 2017, pp.244-260; Graham M. Davies, 'Identification of Familiar Faces after Long Intervals: The Tichborne Claimant Revisited', Applied Cognitive Psychology, Vol. 30, 2016, pp.484-489.

${ }^{37}$ Cassie Dawson, “"The Slaughterman of Wagga Wagga”, Imposture, National Identity, and the Tichborne Affair', Australian Literary Studies, Vol. 21, no. 4, 2004, pp.1-13; Everest-Phillips, 'The 1871 'Tichborne Claimant' medal', pp.1-21.

${ }^{38}$ Benjamin Wilkie, The Scots in Australia, 1788-1938 (Woolbridge: The Boydell Press, 2017), p.13; John Wilson, 'Scots - 1853-1870: a surge of Scots', Te Ara - the Encyclopedia of New Zealand, http://www.TeAra.govt.nz/en/scots/page-4, accessed 9 May 2020.

${ }^{39}$ Wilkie, The Scots in Australia, p.26.

${ }^{40}$ Rebecca Lenihan, From Alba to Aotearoa: Profiling New Zealand's Scots migrants, 1840-1920 (Dunedin: Otago University Press, 2015), pp.65-66. See also Brad Patterson, Tom Brooking, Jim McAloon, Rebecca Lenihan, and Tanja Bueltmann, Unpacking the Kists: The Scots in New Zealand (Montreal \& Kingston: McGillQueen's University Press, 2013), p.23.
} 
games, associational culture, numbered Scottish Presbyterian communities, and the erection of statues of historical figures. ${ }^{41}$ Less attention has been paid to how criminal trials might also be construed as markers of Scottish identity. It has been suggested that many Scots in Britain found a sense of 'perverse satisfaction' and national pride in how the Smith case, along with her individualism and opposition to Victorian conventionalism, had caused more sensation in London and across Britain than the trial of William Palmer, an English doctor and convicted serial poisoner, the previous year. ${ }^{42}$ Whether Australian Scots expressed a similar sense of pride and fascination in the Smith case is a key focus in Chapter Two of this thesis.

At a time when questions of a separate identity from Britain were being raised, as Elizabeth Morrison points out, the large volumes of 'home' news reproduced in colonial newspapers 're-affirmed British origins and maintained connections' over the mid-late nineteenth century. ${ }^{43}$ During the month of September 1857, the Indian uprisings against the British East India Company, debate over admitting Jews to sit in the British parliament, the growth of Italian nationalism, and the French general election were major news items of the day. But it was the trial of Madeleine Smith, as Melbourne's Herald opined, that created an 'intense interest, as you will judge by the length you will find it reported in all the papers' ${ }^{44}$

During both the Smith and Tichborne trials, newspapers served as the primary means by which information about current events was disseminated across the empire. Anderson's 'imagined communities' paradigm is one framework that scholars have applied to their understanding of the period. He argues that printed discourse helped foster national identities by creating 'imagined communities' of readers. Because of its wide dissemination yet transient lifespan, a newspaper could be simultaneously read by large numbers of readers (a 'mass ceremony') before that newspaper's obsolescence the following day. ${ }^{45}$ Accounting for delays in time and place, C. A. Bayly has similarly analysed the role of newspapers in forging networks

\footnotetext{
${ }^{41}$ For example, see Cliff Cumming, 'Scottish National Identity in an Australian Colony', The Scottish Historical Review, Vol. 72, no. 193, 1993, pp.22-38; Brad Patterson, Tom Brooking, Jim McAloon, Rebecca Lenihan, and Tanja Bueltmann, Unpacking the Kists: The Scots in New Zealand (Montreal \& Kingston: McGill-Queen's University Press, 2013); Valerie Wallace, Scottish Presbyterianism and Settler Colonial Politics: Empire of Dissent (Cham: Palgrave Macmillan, 2018); Ben Wilkie, 'Scottish Identity in Stone: Statues of Robert Burns and William Wallace in Ballarat', Victorian Historical Journal, Vol. 84, no. 2, 2013, pp.279-302.

42 Jenkins, Madeleine Smith on Trial, pp.197-198.

${ }^{43}$ Elizabeth Morrison, Engines of Influence: Newspapers of Country Victoria, 1840-1890 (Melbourne: Melbourne University Press, 2005), p.104.

${ }^{44}$ Quoted in Kyneton Observer, 8 September 1857, p.3.

45 Anderson, Imagined Communities, pp.34-35.
} 
of readers across the British Empire. ${ }^{46}$ Tony Ballantyne describes these networks as 'webs' that connect disparate sites of colonisation into imperial circuits of information exchange. He argues that 'useful knowledge' contained in newspapers helped cultivate 'moderate and stabilising social change' by uplifting settlers and colonised subjects alike. ${ }^{47}$

Dependent on the empire's elaborate systems of information exchange, metropolitan newspapers were 'keenly awaited' by local newspaper editors and readers in Australia and New Zealand; reporters competed to be the first to purchase newspapers on incoming ships from Britain and then 'cut and paste' items of foreign correspondence in their local papers. ${ }^{48}$ The spread of news from Britain to the colonies was slow during the $1850 \mathrm{~s}$, often taking three months to reach Australia and New Zealand via ship. ${ }^{49}$ As a result, word of the Smith case was not published in colonial papers until at least June 1857. Nonetheless, in Australia, 'The Glasgow Poisoning Case' was widely reported in the press, as updates on the trial were sourced from British media outlets, such as The Times, and published in local newspapers almost daily thereafter. The case of Madeleine Smith, as the New Zealander reported, 'is one which comes home to every hearth and every heart' ${ }^{50}$

While Smith's ties to Australia tended to be figurative and sometimes speculative, the Claimant had a direct, tangible connection to white colonial Australians that warrants further analysis. During the height of the Tichborne sensation from the late 1860s to the mid-1870s, major technological advancements accelerated the spread of news between metropole and colony. With the trans-Atlantic telegraph cable linking Europe and America by 1866, telegraph lines were established across Australia and, by the end of 1869, connected most of Australia's capital cities (except for Perth). ${ }^{51}$ Colonial communications were further streamlined by the

\footnotetext{
${ }^{46}$ C. A. Bayly, 'Informing Empire and Nation: Publicity, Propaganda and the Press, 1880- 1920', in Hiram Morgan (ed.), Information, Media and Power Through the Ages (Dublin: University College Dublin Press, 2001), pp.179-201.

${ }^{47}$ Tony Ballantyne, Webs of Empire: Locating New Zealand's Colonial Past (Wellington: Bridget Williams Books, 2012), p.69.

${ }^{48}$ Zoë Laidlaw, Colonial Connections, 1815-1845: Patronage, the Information Revolution and Colonial Government (Manchester; New York, NY: Manchester University Press, 2005), p.17; Ross Harvey, 'Bringing the News to New Zealand: The supply and control of overseas news in the nineteenth century', Media History, Vol. 8, no. 1, 2002, pp.24-25.

${ }^{49}$ Simon Potter, News and the British World: The Emergence of an Imperial Press System (Oxford: Oxford University Press, 2003), p.27.

${ }^{50}$ New Zealander, 7 October 1857, p.2.

${ }^{51}$ Sam Hutchinson, Settlers, War, and Empire in the Press: Unsettling News in Australia and Britain, 18631902 (Cham: Palgrave Macmillan, 2018), p.8.
} 
completion of the Overland Telegraph Line in 1872, which connected Port Augusta to Darwin and allowed information to be passed to and from Britain within the space of forty-eight hours. ${ }^{52}$

While the slower mail steamers continued to provide overseas news to the colonies, British and colonial press outlets, such the Argus and the Sydney Morning Herald, entered into arrangements with telegraphic agencies, such as Reuters, to be the first to gather supplies of cable news - the most 'important' of news - as former Victoria Premier John MacPherson declared in $1873 .{ }^{53}$ The increased immediacy in receiving the news, Sam Hutchinson argues, created a 'heightened sense of familial belonging to the empire' for British readers both at 'home' and abroad; as a product of the rise of nineteenth-century commodity culture, the Victorian-era press, Hutchinson writes, was 'tailored to meet the demands of immediacy and, to varying degrees, populism' ${ }^{54}$ 'Empire' became omnipresent. Alex Nalbach notes that just as colonial news became a more regular fixture in metropolitan newspapers, agencies could also guide public opinion in the peripheries by dominating newspaper columns with their news items and championing themselves as instruments of 'intelligent and pacific penetration'. ${ }^{55}$ But, as the Australian coverage of the Tichborne case shows, colonial newspapers were far from passive receivers of British news stories. They were also organs for voicing dissent, particularly when those stories resonated so close to home.

Australian interest in the Madeleine Smith and Tichborne cases prevailed amidst the advent of more sensational forms of journalism from the 1880s. 'New Journalism', as various scholars have called it, drew on earlier attempts to appeal to a growing mass market of readers from the mid-nineteenth century. It marked a significant shift away from primarily parliamentary and political news toward a more novelised, accessible, and sensational style of reporting across the empire. ${ }^{56}$ The growth of telegraphic news to the colonies from the $1870 \mathrm{~s}$ contributed to a demand for immediacy, and thus telegraphic agencies flashed both breaking political and military news as well as 'soft' gossip and 'human interest' stories. ${ }^{57}$ Whereas criminal trials were traditionally reported on through painstaking attention to courtroom

\footnotetext{
${ }^{52}$ Morrison, Engines of Influence, p.204.

53 'European Telegrams', VPD, Vol. 16, 1873, pp.990-1012; Morrison, Engines of Influence, pp.204-205.

${ }^{54}$ Hutchinson, Settlers, War, and Empire in the Press, p.8.

55 Alex Nalbach, “"The Software of Empire'”: Telegraphic News Agencies and Imperial Publicity, 1865-1914', in Julie F. Codell (ed.), Imperial Co-Histories: National Identities and the British and Colonial Press (Madison: Fairleigh Dickinson University Press, 2003), pp.76-78.

${ }^{56}$ Christopher A. Casey, 'Common Misperceptions: The Press and Victorian Views of Crime', Journal of Interdisciplinary History, Vol. 41, no. 3, 2011, pp.372-373; Andrew Griffiths, The New Journalism, the New Imperialism and the Fiction of Empire, 1870-1900 (Basingstoke: Palgrave Macmillan, 2015), p.7.

${ }^{57}$ Nalbach, "“The Software of Empire", p.77.
} 
proceedings albeit with sensationalised headings, it became increasingly common in the late nineteenth century to tell the story of criminals through a more subjective and digestible narrative form. ${ }^{58}$ Stories about Smith and the Claimant were often revived by continued sightings of the former and detailed affidavits about the latter.

This project has involved compiling nineteenth-century Australian newspaper articles on or referring to the Smith and Tichborne cases using the National Library of Australia's Trove database. Over two-thousand relevant articles from 1857 to 1900 were then added to a bespoke database. It is important to note that while both the database and this thesis's attempts to analyse the coverage of the cases are far-reaching, not all relevant newspapers have survived, were available at the time of writing, or have been digitised. Although the focus of this thesis centres on Australia, coverage of the cases in a New Zealand context is also analysed, particularly for the Smith case where sightings of Smith and legal debates over the case's verdict were prominent.

Many primary and some secondary sources analysed in this thesis discuss the coverage of the two trials in terms of their popularity in or 'impact' on Australia, Britain, and other parts of the British Empire. Any assessments of popularity, public opinion, and 'impact' are bound by the practice of exclusion. The colonial newspaper press - the basis for much of the primary research undertaken in this thesis-gave voice to individuals, groups, and cultures while marginalising others. As Catherine Hall has noted, 'the time of empire was the time when anatomies of difference were being elaborated, across the axes of class, race and gender'. ${ }^{59}$ Thus, it is important to note that this thesis largely examines the reception of the two trials within a developing white colonial settler culture; one that was predicated on the process of differentiation, between colonisers and colonised, men and women, and classes. The thesis does not attempt to measure the colonial 'impact' of the cases, nor does it attempt to celebrate or denigrate the role of the colonial press networks that gave the cases an audience. Rather, it aims to chart the complex ways in which the colonial press covered the cases for a predominantly British settler audience, with all its practices of division, marginalisation, and exclusion in mind.

Reflecting on the Smith case in 1928, The Bulletin in Australia noted that no trials outside the Tichborne and Smith cases had 'so stirred the British-speaking world in the

\footnotetext{
${ }^{58}$ Griffiths, The New Journalism, pp.1-7.

${ }^{59}$ Catherine Hall, Civilising Subjects: Metropole and Colony in the English Imagination, 1830-1867 (Cambridge: Polity Press, 2002), pp.16-17.
} 
nineteenth century'. ${ }^{60}$ At the height of the respective cases, colonial press outlets in Australia updated readers almost daily, lent their voices to the surrounding social debates that were occurring in the metropole, and continued to engage in speculation decades after the trials had ended. The two cases had direct but in many ways hitherto unexamined links to Australia's social and cultural history. They were not the only legal cases to become 'sensations' in the nineteenth century, but they were unique in the way the figures at the centre of the two had complex afterlives as colonial icons who aroused debate over local and national identity, sexuality, 'respectability', and crime in Australia. By charting the Australasian coverage of the two cases, alongside other contemporary trials, this thesis explores how the cases caught the attention of Britons both at 'home' and in Australia. Drawing on familiar and original research, it argues that the cases helped forge, reaffirm, and challenge concepts of identity and belonging in a colonial setting. It assesses how varied debates over femininity, masculinity, sexuality, crime, class, and respectability were ignited not just in Britain, but in Australia too.

The first chapter provides an overview of how the two cases played out and were reported on in Britain. Central to the discussion here is the role that reports of criminal trials had in the dissemination of information throughout Britain, correlations between crime and sensationalism, and how newspapers generally reacted to the respective trial verdicts. Using findings from relevant British primary and secondary sources, the chapter explains why the cases became sensations in Britain by drawing on the wider-and often overlapping - social, political, and cultural contexts in which they occurred. While Chapters Two, Three, and Four focus specifically on the cases' sensational reactions in Australia, Chapter One shows how Victorian ideas about class, respectability, gender, and national identity made Smith and the Tichborne Claimant sensations in the first place.

Combining findings from newspapers, magazines, books, pamphlets, and parliamentary debates, Chapter Two assesses how each case contributed to discussions about identity in Australia. The chapters evaluate how newspaper coverage of the trials differed from that in Britain. Discussion of the Smith case focuses on reported sightings of Smith in Australia and New Zealand, the cultural fascination that her trial aroused in a colonial context, and how her connections to Australia illuminated the hybridity of Scottish, British, and Australian identities. Discussion of the Tichborne case explores how Australians used the newspaper press to respond

60 'Society', The Bulletin, 27 June 1928, p.11. 
to representations of Australia propagated by the Tichborne phenomenon in Britain and how the case was variously characterised as a lucrative source of pride.

Drawing on further primary newspapers, magazines, books, pamphlets, and parliamentary debates, Chapters Three and Four centre on how the themes of gender and class permeated the coverage of each case. The thesis compares how both Smith's and the Claimant's character, appearance, and sexuality featured across coverage of their trials and contributed to wider intersectional debates about gender and identity, and their relationship with crime. Chapter Four assesses debate over class and criminality that the two trials aroused, what 'respectability' meant in a colonial setting, and how class debates differed between metropole and colony. 


\section{Chapter One: Coverage in the British Newspaper Press}

In 1857, amidst the 'period of anguish and suspense' stirred by the Indian uprisings, the 'thoughts of the public at home', wrote legal historian James Beresford Atlay, were 'even more closely occupied by a scene at the High Court of Justiciary of Edinburgh, where for seven long days the life of a girl of one-and-twenty [Madeleine Smith] was hanging in the balance on a charge of foul and cold-blooded murder'. ${ }^{1}$ Similarly, at the conclusion of the long-running Tichborne case in 1874, the Observer remarked that 'for the greater part of the seven years since the Claimant appeared on English soil it may be said that no subject whatever occupied so large a space of the human mind'. ${ }^{2}$ By exploring the coverage of the Madeleine Smith and Tichborne cases in British newspapers, this background chapter examines how the British media served as a vehicle for the enormous fixation that the Victorian public afforded to the two cases. Much of the Australian coverage of the cases, as analysed in Chapters Two, Three, and Four, dealt with ideas about class, respectability, gender, and national identity that were brought up by the cases in highly reactive ways. The purpose of this chapter is to show precisely what it was that Australian newspapers were reacting to: the ways in which British newspapers themselves reacted and what that said about Victorian society. The chapter provides an overview of how the cases played out and how newspapers responded in ways that ranged from outward condemnation of the two figures to passionate support. The chapter argues that both the Smith and indeed the Tichborne cases were born out of a contemporary fascination with crime and criminality; that both cases confronted Victorian notions of 'respectability'; that Smith's case reinforced anti-French stereotypes associated with Emile L'Angelier, and that the Tichborne case helped contribute to varying attitudes toward and about colonial life.

\footnotetext{
${ }^{1}$ James Beresford Atlay, Famous Trials of the Century (London: Grant Richards, 1899), p.91.

${ }^{2}$ Quoted in Douglas Woodruff, The Tichborne Claimant: A Victorian Mystery (London: Hollis and Carter, 1957), p.xiii.
} 


\section{Madeleine Smith}

The scene at the High Court of Justiciary in Edinburgh on the first day of the Madeleine Smith trial on 30 June 1857 was one of unusual excitement. Crowds gathered outside hours before the trial's commencement; the public gallery was instantly filled, many were turned away, police officers were on hand to clear the lobbies, and scores of onlookers waited in the streets throughout the day to obtain titbits on the trial's progress. ${ }^{3}$ It was not wholly unprecedented for criminal trials to stir such sensation in Britain, but it was also not often that a young woman of Smith's social standing appeared before court charged with murder let alone occasion the level of amazement, as the Caledonian Mercury reported, that 'such a character existed in a quiet Glasgow house'. ${ }^{4}$

One of the trial's most distinctive features, especially for observers outside of Scotland, was its jury. Scottish criminal law is predicated on not two verdicts but three: 'guilty', 'not guilty', and 'not proven'. Unlike its English counterpart, which until 1967 required unanimous agreement among twelve jurors, the chosen verdict is decided by a simple majority in a fifteenperson jury. ${ }^{5}$ As was customary at the time, the jury was all-male. Most of the jurors were also of middle- or working-class backgrounds. ${ }^{6}$ As the trial unfolded, Smith's erotic letters to L'Angelier were published in the press and read out in court; 'heavy betting' took place as to the result; and contemporary observers frequently commented on Smith's appearance and demeanour. ${ }^{7}$ The Ayrshire Express noted that 'every day sees hundreds at the door of the court, who would willingly expend guineas in obtaining a look at the young lady'. ${ }^{8}$ There was little to set her apart from other young middle-class Glaswegian women of the era, as Eleanor Gordon and Gwyneth Nair write. ${ }^{9}$ She was 'elegant without show', 'vivacious' and 'stylish', andabove all—calm, composed, and outwardly unmoved by the 'horror' of her situation. ${ }^{10}$

\footnotetext{
${ }^{3}$ Eleanor Gordon and Gwyneth Nair, Murder and Morality in Victorian Britain: The Story of Madeleine Smith (Manchester: Manchester University Press, 2010), p.125; Edinburgh Evening Courant, 27 June 1857, p.2; Dundee Courier, 1 July 1857, p.3; Glasgow Herald, 1 July 1857, p.4.

${ }^{4}$ Caledonian Mercury, 14 July 1857, p.4.

${ }^{5}$ Section 13 of The Criminal Justice Act 1967 removed the requirement for unanimous verdicts and permitted majority (10:2) verdicts for juries in England. See Peter Duff, 'The Scottish Criminal Jury: A Very Peculiar Institution', Law and Contemporary Problems, Vol. 62, no. 2, 1999, p.173.

${ }^{6}$ William W. J. Knox, The Lives of Scottish Women: Women and Scottish Society 1800-1980 (Edinburgh: Edinburgh University Press, 2006), p.64; Gordon and Nair, Murder and Morality, p.1; The Times, 2 July 1857, p.126.

${ }_{7}^{7}$ James C. Whorton, How Victorian Britain was Poisoned at Home, Work, and Play (Oxford: Oxford University Press, 2010), p.262.

${ }^{8}$ London Evening Standard, 7 July 1857, p.8.

${ }^{9}$ Gordon and Nair, Murder and Morality, p.1.

${ }^{10}$ Ibid, p.1; The Times, 2 July 1857, p.5.
} 
While the letters and testimonies from witnesses to Smith's affair with L'Angelier might have hinted at her moral culpability, it was the tension evident in the final months of the couple's correspondence that proved particularly critical for the prosecution. L'Angelier's threats to show the letters to her father, James; her pleas for him not to; their growing lack of trust for one another amidst L'Angelier's sudden ill health in February 1857; and his abrupt return to Glasgow to meet her just before his death gave the prosecution seemingly sound circumstantial evidence with which to charge her with his murder. ${ }^{11}$ Additionally, Smith admitted to lying to chemists Murdoch and Currie about purchasing arsenic from them to kill rats at the family homes at Gare Loch and at Blythswood Square because she did not wish them to know that she was going to use it as a cosmetic remedy for her poor complexion. ${ }^{12}$ She had learned about the cosmetic — albeit scientifically contested — benefits of arsenic-eating in Edinburgh newspapers, such as Chambers's Journal and Blackwood's Magazine, and at her Clapton boarding school. ${ }^{13}$

The defence counsel contorted the very evidence that damned Smith - the purchase of arsenic and her sexually-charged letters-by portraying L'Angelier as the 'corrupting influence' and 'seducer' of a naïve young girl, who on more than one occasion threatened to take his own life and had been 'in the habit of using arsenic himself' ${ }^{14}$ Thus, it was argued that he committed suicide as an act of revenge against Smith. On the count of attempted murder on the first occasion in February 1857, the head of Smith's defence counsel, John Inglis, outlined how L'Angelier's first bout of illness fell before the date that Smith purchased arsenic on 21 February, thereby removing her as a suspect. On the second count of attempted murder and third count of actual murder, he argued that there was insufficient evidence to prove that Smith and L'Angelier had met on the day of L'Angelier's second bout of illness or on the night of his death. ${ }^{15}$ Moreover, he pointed out the incongruity of Smith's eagerness to avoid exposing her

\footnotetext{
${ }^{11}$ F. Tennyson Jesse (ed.), Trial of Madeleine Smith (Sydney, Wellington, and Calcutta: Butterworth \& Co. (Australia), Limited, 1927), pp.371-390. L'Angelier's ill health in February 1857 was the basis on which the first two counts of attempted murder against Smith were charged.

${ }^{12}$ Alexander Forbes Irvine, Report on the Trial of Madeleine Smith: before the High Court of Justiciary at Edinburgh, June 30th to July 9th, 1857, for the alleged poisoning of Pierre Émile L'Angelier (Edinburgh: T. \& T. Clark, Law Booksellers, George Street; Glasgow: Smith and Son; Aberdeen: Wyllie and Son; London: Stevens \& Norton, \& and Sympkin \& Co., 1857), pp.52-53, 73, 78.

${ }^{13}$ John Morison, A Complete Report of the Trial of Miss Madeline Smith, for the Alleged Poisoning of Pierre Emile L'Angelier (Edinburgh: W. P. Nimmo, 1857), pp.48-50, 176. See also Blackwood's Edinburgh Magazine, Vol. 74, July-December, 1853 (Edinburgh and London: William Blackwood \& Sons; 1853), pp.687-695; Charles Boner, 'Poison-Eaters', Chambers's Journal of Popular Literature Science and Arts, Vol. 5, JanuaryJune 1856 (London and Edinburgh: W. \& R. Chambers, 1856), pp.90-92; Whorton, How Victorian Britain was Poisoned, p. 270.

${ }^{14}$ James Crabb Watt, John Inglis, Lord Justice-General of Scotland: A Memoir (Edinburgh: William Green \& Sons, 1893), pp.337, 371; Whorton, How Victorian Britain was Poisoned, pp.266-267.

${ }^{15}$ Gordon and Nair, Murder and Morality, p.138.
} 
letters with the fact that the letters were so easily found in L'Angelier's apartment after his death. 'What possible advantage could she expect from L'Angelier ceasing to live, so long as the letters remained?', he remarked. ${ }^{16}$

Inglis's closing statement on the eighth day also sought sympathy from the jury for Smith's plight. He compared the case with that of Eliza Fenning, a young domestic servant who was sentenced to death in 1815 for attempting to murder (by arsenic poisoning) family members who employed her in London. Remarking that Fenning had a similarly calm self-possession and looked 'as serene as an angel' before her execution, Inglis noted that it was only after her death that the true perpetrator confessed the crime on his death-bed, 'too late to avoid the enacting of a most bloody tragedy'. ${ }^{17}$ Thus, his plea to the jury was that they avoid making the same mistake by relying too strongly on circumstantial evidence.

The jury took just half an hour to deliberate before returning the verdicts, and the final verdict of 'not proven' on the murder charge was agreed upon by a majority of thirteen, with the remaining two voting 'guilty'. ${ }^{18}$ The 'not proven' verdict resulted in yet more widespread conjecture surrounding Smith's guilt. In Edinburgh, the verdict was received with applause by onlookers in and beyond the courthouse. ${ }^{19}$ 'I was delighted with the loud cheer the Court gave', Smith wrote. ${ }^{20}$ William Knox credits the jury's sympathetic stance toward Smith to its all-male, predominantly middle-class composition. He argues that they 'saw in her their daughters' and subscribed to the 'victim theory' of the defence counsel. ${ }^{21}$ Smith garnered the favour of the crowds with her 'courage and demeanour', bolstered by the fact that Glasgow merchants and friends of the Smith family had raised 'twice over the large sum expended' — upwards of $£ 4,000$ —on her defence. ${ }^{22}$ But she would soon discover that the public feeling in Scotland—and indeed much of the British world, as Chapter Two discusses - was far from unanimous in its support.

Historians have variously explored the public excitement stirred by criminal cases and their subsequent trials in Victorian Britain. Christopher Casey argues that the nineteenth-century

\footnotetext{
${ }^{16}$ Watt, John Inglis, Lord Justice-General of Scotland. p.366.

${ }^{17}$ Ibid, p.372.

${ }^{18}$ F. Tennyson Jesse, 'Madeleine Smith', in Harry Hodge (ed.), Famous Trials: Volume I (Middlesex and New York: Penguin Books, 1941), p.46.

${ }^{19}$ Atlay, Famous Trials of the Century, p.111; Age, 4 September 1857, p.3; Douglas MacGowan, The Strange Affair of Madeleine Smith: Victorian Scotland's Trial of the Century (Edinburgh: Mercat Press, 2007), pp.131132.

${ }^{20}$ Jesse, 'Madeleine Smith', p.47.

${ }^{21}$ Knox, The Lives of Scottish Women, p.64.

${ }^{22}$ Atlay, Famous Trials of the Century, p.111; 'The Defects in the Evidence of the Glasgow Poisoning Case', in Jacob Bell (ed.), Pharmaceutical Journal and Transactions. Volume XVII. 1857-58 (London: John Churchill, New Burlington Street; Edinburgh: Maclachlan \& Stewart; Dublin: Fannin \& Co., 1858), p.114.
} 
media created a culture 'more conversant with violent crime than any society of the previous century'. People across the 'entire reading and listening public' in Britain, Casey suggests, subscribed to the 'myth of rising crime' promulgated in the press, despite an actual decline in crimes of all kinds from the late 1840s. ${ }^{23}$ 'Allowing for the likelihood of exaggeration', Lindsay Farmer adds, the scale of interest in criminal justice in the nineteenth century, from packed courtrooms and crowded executions to daily accounts and reports of trials in broadsides and newspapers, was telling. ${ }^{24}$ Crime took many forms, and there were marked discrepancies in the way types of crimes provoked public fear. The developing field of criminology focused strongly on regular offenders, such as professional thieves, swindlers, and imposters. These 'poster criminals', as Peter Becker notes, stoked the nightmares of citizens about the 'possible breakdown of social order' because 'they appeared not just as isolated instances of men gone astray'. ${ }^{25}$ 'Poster criminals' invaded the comfort of the 'respectable' classes; while pickpockets and prostitutes were seen as moral contagions in the streets, burglars of all kinds, including those entrusted to share the domestic spaces with their employers, such as domestic servants, threatened them in their own homes. ${ }^{26}$

Crime reports in the press drew on stereotypical assumptions that linked criminality to age, gender, character, appearance, and respectability, and they were often headlined with sensationalist phraseology for the purposes of grabbing readers' attention. ${ }^{27}$ Sociological interpretations centred on identifying a certain 'type' of criminal based on factors such as class, poverty, and education. Others, like the seminal work of journalist Henry Mayhew, London Labour and the London Poor (1851), disagreed and - using urban London as a case studyconcluded that lawlessness was a choice and pervaded all areas of society. ${ }^{28}$ While the 'poster criminals' aroused fears over the upsurge of traditional crimes, it was the relatively more invisible, unsuspecting, and one-off 'respectable' criminal that aroused a lurid cultural fascination in the media hitherto unseen. Embezzlement, fraud, blackmail, and poisonings were

\footnotetext{
${ }^{23}$ Christopher A. Casey, 'Common Misperceptions: The Press and Victorian Views of Crime', Journal of Interdisciplinary History, Vol. 41, no. 3, 2011, pp.381-185.

${ }^{24}$ Lindsay Farmer, 'With all the Impressiveness and Substantial Value of Truth': Notable Trials and Criminal Justice, 1750-1930', Law and Humanities, Vol. 1, no. 1, 2007, p.58.

${ }^{25}$ Peter Becker, 'Researching Crime and Criminals in the 19th Century' in Ruth Ann Triplett (ed.), The Handbook of the History and Philosophy of Criminology (Hoboken: John Wiley \& Sons, Inc., 2018), pp.36-37.

${ }^{26}$ Lesa Scholl, 'Ubiquitous Theft: The Consumption of London in Mayhew's Underworld', in Grace Moore and Michelle J. Smith (eds.), Victorian Environments: Acclimatizing to Change in British Domestic and Colonial Culture (London: Palgrave Macmillan, 2018), pp.91-92.

${ }^{27}$ Judith Rowbotham and Kim Stevenson, 'Causing a Sensation: Media and Legal Representations of Bad Behaviour', in Judith Rowbotham and Kim Stevenson (eds.), Behaving Badly: Social Panic and Moral Outrage - Victorian and Modern Parallels (Hampshire and Burlington: Ashgate, 2003), pp.38-39.

${ }^{28}$ Scholl, 'Ubiquitous Theft', pp.89-90.
} 
among some of the more secretive crimes with which members of Britain's respectable classes became implicated. ${ }^{29}$ Murder had always figured among the most shocking of all crimes, but murders committed in the decorum of Victorian homes were those that were most widely cemented in the annals of crime. Domestic murders, and particularly murders of 'lovers, spouses, or love rivals', as Bridget Walsh discusses, received extensive coverage for the ways they contested ideas surrounding 'masculine identity, the acceptable limits of female behaviour, and the potential for secrecy and deviance afforded by the privacy of the home'. ${ }^{30}$ Such crimes presented a very different kind of criminological anxiety for respectable Britons; they were not committed by an externalised, unruly populace but were instead born within and even dependent on respectability itself. ${ }^{31}$

Domestic murderers stood out in the press because they challenged the notion that criminality stemmed from an underworld of poverty and unrespectability. They also- despite a growth in the number of domestic murder cases, or at least reports of the crimes, particularly from the $1840 \mathrm{~s}$ - remained anomalous. ${ }^{32}$ Less representative of a trend in murdering than as extreme examples of 'polite' society's perceived moral decay, domestic murderers proved shocking because of their rarity. As named, known figures, they garnered a kind of celebrity status through their omnipresence in newspapers, pamphlets, broadsides, novels, cartes de visite, and museums, as shown by the establishment of the 'Chamber of Horrors' in Madame Tussaud's wax exhibition in London in 1835. Commenting on the public's fascination with particular criminals, the satiric Punch was not altogether hyperbolic in noting, in 1849, that 'upon the apprehension of a criminal, we notoriously spare pains to furnish the nation with his complete biography', employ artists to sketch his likeness, and draw on gaolers and other authorities to 'describe every act and deed of the prisoner' from his appearance and dress to his sleeping patterns and the meals he takes. ${ }^{33}$

Public shaming traditions also went hand-in-hand with bringing criminals to justice, and served to publicise scandal, rectify bad behaviour, and warn society of the consequences of

\footnotetext{
${ }^{29}$ Martin J. Wiener, Reconstructing the criminal: culture, law, and policy in England, 1830-1914 (Cambridge: Cambridge University Press, 1990), pp.244-245.

${ }^{30}$ Bridget Walsh, Domestic Murder in Nineteenth-Century England: Literary and Cultural Representations (Surrey, UK and Burlington, US: Ashgate, 2014), p.2.

${ }^{31}$ Wiener, Reconstructing the criminal, pp.244-245.

32 Judith Knelman, Twisting the Wind: The Murderess and the English Press (Toronto, Buffalo, and London: University of Toronto Press, 1998), p.25; Casey, 'Common Misperceptions', pp.376-377.

${ }^{33}$ Knelman, Twisting the Wind, p.21-22.
} 
committing similar indiscretions. ${ }^{34}$ Executions merged public humiliation with suffering, and made use of the body to illustrate a lesson as well as to instil fear among onlookers. ${ }^{35}$ But over the course of the nineteenth century, public shaming traditions became increasingly refocused on trials over executions, as capital punishment and the more violent methods of public exhibition of criminals became less common. ${ }^{36}$ 'The age of the trial', as George Robb and Nancy Erber have called it, was at its inception at the time of Madeleine Smith's case, and thus the courtroom figured as its own arena for public shaming that merged the moral and religious censure of the church with the spectacle of the theatre. ${ }^{37}$ Examining the context of 1870s Italy, Mark Seymour suggests that the courtroom, through its often 'singularly sober emotional style' operated as a kind of 'emotional arena' where the 'experience and expression of emotions, and their staging and shaping, are likely to follow patterns distinctive to that space'. ${ }^{38}$ Following Benedict Anderson's 'imagined communities' paradigm, newspapers could also be conceived as their own emotional arenas, and the media played a paramount role in broadcasting the spectacle of shame inside the courtroom to outside constituents by drawing on the discursive, sometimes shielding, power of the written word and the diffusion of newspapers throughout the globe. The removal of newspaper taxes, such as the stamp duty in 1855 , made the British newspaper industry increasingly commercialised over the mid-century and more accessible to larger readerships. ${ }^{39}$ Trial reports, as David Barrie argues, had an authority and legitimacy among Britain's middle classes who attached significant cultural value to the printed word. ${ }^{40}$ The public shaming of Smith and the Tichborne Claimant was not limited to the courtroom but, by way of the Smith trial's inconclusive verdict and responses to the Claimant's eventual imprisonment, heavily reliant on the organ of the press in the years that followed.

While Smith escaped capital punishment, she was not free from the clouds of doubt and judgement that hung over her and the public notoriety that had tarnished the Smith family's

\footnotetext{
${ }^{34}$ David Nash and Anne-Marie Kilday, Cultures of Shame: Exploring Crime and Morality in Britain 1600-1900 (Basingstoke: Palgrave Macmillan, 2010), p.10.

${ }^{35}$ Randall McGowen, 'The Death Penalty', in Paul Knepper and Anja Johansen (eds.), The Oxford Handbook of The History of Crime and Criminal Justice (Oxford: Oxford University Press, 2016), p.617.

${ }^{36}$ Farmer, 'With all the Impressiveness', pp.58-59; Michel Foucault, Discipline and Punish: The Birth of the Prison, trans. Alan Sheridan (London: Penguin Books, 1977. First published in 1975), pp.8-10.

${ }^{37}$ George Robb and Nancy Erber, 'Introduction', in George Robb and Nancy Erber (eds.), Disorder in the Court: Trials and Sexual Conflict at the Turn of the Century (Basingstoke and London: Macmillan Press, 1999), p.4.

${ }^{38}$ Mark Seymour, Emotional Arenas: Life, Love, and Death in 1870s Italy (Oxford: Oxford University Press, 2020), pp.12-13.

${ }^{39}$ Matthew Rubery, The Novelty of Newspapers: Victorian Fiction after the Invention of the News (Oxford: Oxford University Press, 2009), pp.5-7.

${ }^{40}$ David G. Barrie, 'Naming and Shaming: Trial by Media in Nineteenth-Century Scotland', Journal of British Studies, Vol. 54, April 2015, pp.375-276.
} 
reputation, particularly in Glasgow. ${ }^{41}$ Many observers saw the letters, which were read out in court on the fifth day, as evidence of Smith's guilt. Beginning in the spring of 1855 and culminating on the day of L'Angelier's death, the letters exposed the sexually promiscuous nature of Smith's two-year relationship with L'Angelier. For the prosecution, the 'incredible evidence' of 'disgrace', 'sin', and 'degradation' shown by Smith was too 'dreadful' to ignore. ${ }^{42}$ As Smith had not kept her letters from L'Angelier, most of the more than 70 letters used as evidence and read out in court were those found in L'Angelier's drawer and written by Smith. Thus, the letters painted a strongly one-sided story of their romance. ${ }^{43}$ They showed that Smith was not merely the innocent victim of L'Angelier's seduction. For the prosecution, her conduct throughout the letters showed 'so entire an overthrow of the moral sense' that many salacious details were removed before being read aloud. ${ }^{44}$ Her lack of grief or remorse following her loss of virginity to L'Angelier in May 1856; her 'talks of the act as hers as much as his'; her continued relations with him following her engagement to Minnoch; and the 'disgusting and revolting language' of her letters exhibited a 'depraved moral state of thought and feeling', as the Annual Register professed. ${ }^{45}$

In contrast to England, which required banns of marriage to be called and that the ceremony take place in a parish church, Scotland - as governed mostly by the Church of Scotland at the time - required only one of the following for a marriage to be constituted as a lawful, albeit 'irregular one: evidence of a private exchange of vows; sexual relations between two unmarried persons following a promise of marriage; or cohabitation as man and wife, known as 'habit and repute'. ${ }^{46}$ 'Irregular' marriages were both legally and morally controversial; Smith's intercourse with L'Angelier, combined with the fact that they referred to each other as husband-and-wife, made their relationship all the more significant, and hence frowned upon, in the eyes of observers. ${ }^{47}$ Presiding judge, Lord Justice-Clerk Hope, also intimated that the correspondence was of 'much importance in ascertaining' Smith's state of mind, whether she

\footnotetext{
${ }^{41}$ MacGowan, Strange Affair, p.138; Knox, The Lives of Scottish Women, p.65.

42 Jesse (ed.), Trial of Madeleine Smith, p.180.

${ }^{43}$ Sara Murphy, 'Inadmissible Evidence: The Trials of Madeleine Smith and Collins's The Law and the Lady', Victorian Literature and Culture, Vol. 44, no. 1, 2016, p.167.

${ }^{44}$ Jesse (ed.), Trial of Madeleine Smith, pp.190-191.

${ }^{45}$ The Annual Register, or a View of the History, Politics, and Literature, for the Year 1857 (London: F. \& J. Rivington, 1857), p.587; Jesse (ed.), Trial of Madeleine Smith, p.191.

${ }^{46}$ Leah Leneman, 'Seduction in Eighteenth and Early Nineteenth-Century Scotland', The Scottish Historical Review, Vol. 78, no. 205, April 1999, p.39; Rebecca Gill, 'The Imperial Anxieties of a Nineteenth-Century Bigamy Case', History Workshop Journal, Vol. 57, 2004, p.61.

${ }^{47}$ Katie Barclay, 'Marriage, Sex, and the Church of Scotland: Exploring Non-Conformity Amongst the Lower Orders', Journal of Religious History, Vol. 43, no. 2, June 2019, p.167; Diamond, Victorian Sensation, p.171.
} 
had the mind of a 'woman driven nearly to madness', and whether she was capable of enacting revenge to avoid the disgrace of having her letters exposed to her father, as L'Angelier threatened before his death. ${ }^{48}$ As Randa Helfield has explored, many media outlets concurred with the insinuation that evidence of Smith's sexual sins were akin to her guilt as L'Angelier's poisoner. ${ }^{49}$ Others correlated the letters with her demeanour. The Glasgow Sentinel saw her 'apparent unconcern' as evidence of her guilt, while The Examiner wrote that 'after what passed between her and the deceased L'Angelier, her composure, in our view, wears the aspect of heartless callousness' ${ }^{50}$

Opinions on Smith's guilt in the press varied significantly. London's Saturday Review, the Glasgow Sentinel, and The Examiner were less than sympathetic, and The Times saw 'no reason for the cheering' that greeted the verdict. ${ }^{51}$ In contrast, the Glasgow Citizen, the Perthshire Courier, and the Spectator singled out L'Angelier as seducer. ${ }^{52}$ As the Spectator asked figuratively, 'is she a Lucretia Borgia' - alluding to the allegations of incest, poisoning, and murder against the Renaissance-era noblewoman — 'or is she only a boarding school miss, led by a designing and theatrical Frenchman into a copy of Parisian romance?'53 The Scotsman simply concluded that Smith was 'either the most fortunate of criminals, or the most unfortunate of women'. ${ }^{54}$ Views on Smith's moral guilt were particularly polarised in Glasgow, a city with a far more diverse middle-class population than Edinburgh, where support for Smith was most pronounced. ${ }^{55}$ The working-class Glasgow Sentinel and Glasgow Chronicle were loud in their critiques of Smith, whereas the Edinburgh Evening Post and Scottish Record expressed compassion for her 'age, sex, and social position' and the Edinburgh Evening Courant saw it 'only too probable that L'Angelier got this most unhappy girl into his power, ruining her, we had almost said, body and soul, prompting her to furnish him with damning evidence of her own shame, with the express and deliberate intention of extorting hush-money from her family' ${ }^{56}$

\footnotetext{
${ }^{48}$ Jesse (ed.), Trial of Madeleine Smith, p.294.

${ }^{49}$ Randa Helfield, 'Poisonous Plots: Women Sensation Novelists and Murderesses of the Victorian Period', Victorian Review, Vol. 21, no. 2, 1995, pp.165-166. The Glasgow Courier, Glasgow Free Press, and Ayrshire Express in Scotland, along with the Saturday Review, Globe, and the English Journal of Education saw Smith's correspondence as incriminating.

${ }^{50}$ Gordon and Nair, Murder and Morality, p.128; The Examiner, 11 July 1857, p.1.

${ }^{51}$ Glasgow Sentinel, 11 July 1857, p.4; The Examiner, 11 July 1857, pp.1-4; The Times, 10 July 1857, pp.8-9; MacGowan, Strange Affair, p.137.

${ }^{52}$ MacGowan, Strange Affair, p.137.

${ }^{53}$ The Spectator: A Weekly Journal of News, Politics, Literature, and Science (London: Joseph Clayton, 1857), p.729.

54 The Scotsman, 5 August 1857, p.3.

55 Eleanor Gordon and Gwyneth Nair, 'The economic role of middle-class women in Victorian Glasgow', Women's History Review, Vol. 9, no. 4, 2000, p.793; Gordon and Nair, Murder and Morality, pp.144.

${ }^{56}$ Gordon and Nair, Murder and Morality, pp.144, 147; Edinburgh Evening Courant, 11 July 1857, p.2.
} 
Indeed, those who were sympathetic toward Smith tended to concur with the prosecution's representation of L'Angelier as the malevolent and manipulative force in the relationship. Although she had transgressed the social norms of her class and gender, many felt that Smith had been led astray by foreign influences. ${ }^{57}$

L'Angelier was twelve years older than Smith, of lower station than Minnoch, and born to French parents in Jersey. Reports on the case frequently labelled him as a 'Frenchman' and many correlated their prejudicial views with disdain for his 'unmanly', 'vain', 'weak-minded', and predatory conduct. ${ }^{58}$ Mary Hartman argues that his 'dandified habits and his personal manner'-which were labelled 'French' — had been 'obstacles to acceptance in the austere Scottish community'. ${ }^{59}$ Witnesses in court spoke of his boastful, charming, and effeminate outward persona, but also of his inward sensitivity and proneness to depressive mood swings. ${ }^{60}$ Lamenting Smith and L'Angelier's relationship as having an 'un-British character', the Glasgow Herald noted that Jersey was so full of French political refugees following Napoleon III's coup of 1851 that L'Angelier was essentially 'French by birth', and suggested that 'the French people are notoriously addicted to the use of cosmetics' ${ }^{61}$ Although L'Angelier's letters had been destroyed, many newspapers filled the gaps with speculation as to his character. As the Galloway Advertiser wrote, 'the very offensiveness' of Smith's letters was 'proof that his must have been still more offensive' ${ }^{62}$

Even those that were dismissive of Smith shared a condemnation of L'Angelier's conduct. Sceptical of the suicide notion, the Medical Times and the Saturday Review nonetheless labelled him a 'scoundrel', and the Liverpool Albion placed blame on Smith for making acquaintances with an unrespectable foreigner and 'selfish profligate, to whom honour and purity were alike unknown'. ${ }^{63}$ Despite being allies in the Crimean War, animosity toward France had been mounting in Britain since Napoleon III's coup and the subsequent growth of France's Second Empire, which rivalled Britain's. Distrust of Napoleon's imperial ambitions, as Jonathan Parry points out, correlated with an urge to uphold Britain's national character and recourse to

\footnotetext{
${ }^{57}$ Helfield, 'Poisonous Plots', p.170.

${ }^{58}$ Gordon and Nair, Murder and Morality, pp.145-146.

${ }^{59}$ Mary S. Hartman, 'Murder for Respectability: The Case of Madeleine Smith', Victorian Studies, Vol. 16, no.

4, 1973, p.393.

${ }^{60}$ Knox, The Lives of Scottish Women, p.54.

${ }^{61}$ Glasgow Herald, 10 July 1857, p.4.

${ }^{62}$ Quoted in Helfield, 'Poisonous Plots', p.167.

${ }^{63}$ Quoted in Morning Post, 20 July 1857, p.2; The Saturday Review of Politics, Literature, Science and Art: Vol. IV (London: Saturday Review Office, 1857), 11 July 1857, pp.26-27; quoted in Dundee, Perth, and Cupar Advertiser, 14 July 1857, p.4.
} 
a long-standing tradition of associating French culture with 'sensuality, profligacy and effeminacy' vis-à-vis the virtues of Protestantism and individual responsibility that were seen as representative of Britain. ${ }^{64}$ Criticisms of L'Angelier as an incarnation of the negative French stereotype thus went hand-in-hand with defensive responses in the press that sought to reassure readers that the whole affair was caused by an outside force and did not reflect British values. ${ }^{65}$

Religion played a prominent role in Victorian society; it not only defined the means of femininity, as Gordon and Nair point out, but it also provided 'meaning and purpose' to women's lives across the empire. ${ }^{66}$ The Smith family were churchgoers, although not wedded to a particular church or denomination, and Smith variously worshipped at Presbyterian, Episcopal, and Roman Catholic churches. ${ }^{67}$ Some religious publications, Hartman argues, were sympathetic to Smith amidst her trial, 'either stoutly maintaining her innocence or defending her for taking righteous revenge against a depraved fortune-hunter' ${ }^{68}$ Similarly, criticisms of L'Angelier were steered by prominent religious figures, such as Reverend George Gilfillan, who later became a minister of the United Presbyterian Church of Scotland, but they too could be matched by testimonies asserting that L'Angelier was a 'well-principled, religious young man'. ${ }^{69}$ Nonetheless, concerns over Smith's - and L'Angelier's - religious faith (or lack thereof) were less significant in coverage of the case than the related question of 'respectability', as this thesis later explores.

While many newspapers shared the view that L'Angelier had a corrupting influence on Smith, not all saw the affair as an anomalous blight on an otherwise respectable and pious Victorian society. Blame for Smith's immoral behaviour was also levelled against deeper, systemic issues for allowing such behaviour to manifest. The Spectator argued that parents' lack of involvement in their children's lives was teaching the 'inexperienced to find companions amid the servants downstairs or the casual acquaintance of the street'. ${ }^{70}$ The Liverpool Albion similarly blamed British society for permitting young women to wander the streets of large towns without restraint, and suggested that Smith's downfall was a lesson to all young women to avoid making acquaintances with young men 'not known to their families or not introduced

\footnotetext{
${ }^{64}$ J. P. Parry, 'The Impact of Napoleon III on British Politics, 1851-1880', Transactions of the Royal Historical Society, Vol. 11, 2001, pp.157, 166.

${ }^{65}$ Gordon and Nair, Murder and Morality, pp.147.

${ }^{66}$ Ibid, p.79.

${ }^{67}$ Ibid, pp.78-79.

${ }^{68}$ Hartman, 'Murder for Respectability’, pp.398-399.

${ }^{69}$ Brian Jenkins, Madeleine Smith on Trial: A Glasgow Murder and the Young Woman Too Respectable to Convict (North Carolina: McFarland \& Company, Inc., 2019), p.119. See also Age, 16 October 1857, p.5.

${ }^{70}$ Quoted in Dundee, Perth, and Cupar Advertiser, 14 July 1857, p.4.
} 
to them by some party who can vouch for their respectability'. ${ }^{71}$ Indeed, the case revealed growing public anxiety over the criminal propensities of respectable, middle-class women and how these propensities were concealed in the seemingly innocent yet unregulated realm of domesticity. $^{72}$

Debate over how the state should manage private relations was growing in Victorian Britain, in part due to the 1857 Matrimonial Causes Act in England, which shifted jurisdiction over divorce from the Church to the state. Challenging the 'separate spheres' paradigm, which associated Victorian women with the private realm of home and family and men with the public realm of work and finance, both the divorce law reform and Smith's trial highlighted how women's private matters could become the subjects of intense public fascination, humiliation, and concern. ${ }^{73}$ That the courtroom and press could work in tandem as arenas for the shaming of convicted criminals meant that Smith was condemned and celebrated outwardly in the courtroom just as she was in the intimacy of newspaper readers' homes.

Following her trial, Smith was said to have moved to Devonport, where she met artist George Wardle and married him in London in 1861. Under the name of Lena Wardle, she became active in London's Socialist circles throughout the 1880s and was a prominent member of textile designer William Morris's Social Democratic League (SDL) in 1884 and later the Social Democratic Club (SDC). ${ }^{74}$ Her attempts to conceal her true identity were not always successful. Irish playwright George Bernard Shaw was also involved in the SDC and remembered hearing a rumour that Lena Wardle was indeed Madeleine Smith but noted that he knew her only to be 'an ordinary good-humored [sic] capable woman with nothing sinister about her'. ${ }^{75}$ Word that the former 'murderess' had become the 'manageress' of the SDC's bar made its way to the pages of Australian newspapers in 1893, but not before newspaper reports in Australia and New Zealand told very different stories of her later life in the colonies, as Chapter Two discusses. ${ }^{76}$

\footnotetext{
71 Ibid.

72 Sheila Sullivan, "“What is the Matter with Mary Jane?": Madeleine Smith, Legal Ambiguity, and the Gendered Aesthetic of Victorian Criminality', Genders, Vol. 35, 2002, p.19.

${ }^{73}$ Gordon and Nair, 'The economic role of middle-class women in Victorian Glasgow', p.791; Sullivan, "'What is the Matter with Mary Jane?", p.11.

${ }^{74}$ Gordon and Nair, Murder and Morality, pp.175-181; Norman Kelvin (ed.), The Collected Letters of William Morris, Volume II, Part B, 1885-1888 (Princeton: Princeton University Press, 1995), pp.704, 781; Dundee Courier, 4 January 1926, p.4.

${ }^{75}$ Quoted in Peter Hunt, The Madeleine Smith Affair (London: Carroll \& Nicholson, 1950), pp.148-149; Dorset County Chronicle, 23 April 1857, p.196.

${ }^{76}$ Argus, 21 January 1893, p.4.
} 
The Smith trial was shocking and scandalous, blending murder, mystery, youthful romance, lustful sensuality, and a 'well-to-do' Scottish setting with an ultimately inconclusive verdict of 'not proven' ${ }^{77}$ Newspapers brought the intimate details of Smith's relationship with L'Angelier into Victorian homes, simultaneously stirring fascination and fear about the criminal propensities of 'respectable' women. However, as coverage of the Tichborne case shows, the mid-nineteenth-century surge of public interest in the courtroom did not always centre around the sinister or the murderous.

\section{The Tichborne Claimant}

News that a portly outbacker from Australia of low station had laid claim to the Tichborne family estates began circulating in the media from 1866, but it was not until after Henriette Tichborne's death in March 1868 that the question of inheritance became most pressing. ${ }^{78}$ Opinions of the true identity of the Tichborne Claimant varied. Some friends of the Tichborne family took to the press to voice their outrage over 'the person calling himself Sir Roger' to 'bear the name and title he has so unwarrantably assumed'. ${ }^{79}$ But the Claimant also garnered a significant following, particularly among those who saw Henriette's willingness to share her income with him, let alone her recognition of him, as decisive. ${ }^{80}$ The Claimant's public supporters were numerous, and funds raised towards his cause allowed for his legal counsel to gather evidence from Britain, Australia, and South America (and the Claimant himself travelled to Chile in September 1868). ${ }^{81}$ However, these efforts were matched by those of the Tichborne family, who hired a private investigator, John Mackenzie of Scotland, to travel to Australia and collect evidence of their own. ${ }^{82}$ Mackenzie's prosecuting inquiries in early 1868 suggested that

\footnotetext{
${ }^{77}$ Richard D. Altick, Victorian Studies in Scarlet (London: J. M. Dent \& Sons Ltd., 1972), p.175.

${ }^{78}$ David Wayne Thomas, Cultivating Victorians: Liberal Culture and the Aesthetic (Philadelphia: University of Pennsylvania Press, 2004), p.87.

79 The Times, 24 May 1867, p.11.

${ }^{80}$ Max Everest-Phillips, 'The 1871 'Tichborne Claimant' medal and the forging of Australia's identity', Journal of the Numismatic Association of Australia, Vol. 24, 2013, p.7. See also The Times, 26 March 1868, p.5.

${ }^{81}$ Christopher Kent, 'Victorian Self-Making, or Self-Unmaking? The Tichborne Claimant Revisited', Victorian Review, Vol. 17, no. 1, 1991, p.19; Hugh Anderson (ed.). Baronet or Butcher? The Trials of the Tichborne Claimant (Victoria: Red Rooster Press, 1999), p.xii.

${ }^{82}$ The Tichborne Romance: A Full and Accurate Report of the Proceedings in the Extraordinary and Interesting Trial of Tichborne v. Lushington, in the Court of Common Pleas, Westminster, for Forty Days, from Wednesday, May 10 to Friday, July 7, 1871; Including the Whole of the Examination, Cross-Examination, and ReExamination of the Claimant 3 (Manchester: John Hayward; London: Simpkin, Marshall, \& Co., 1871), pp.44, 273.
} 
Castro was 'identical' to a man by the name of Arthur Orton, a butcher's son from Wapping, London, who had sailed to Chile as a teenager and later arrived in Hobart, Tasmania in $1853 .{ }^{83}$

After many delays caused by the Claimant's negotiations with the Tichborne family, along with his financial troubles, the eventual civil case of Tichborne $v$ Lushington began on 10 May 1871 at the Court of Common Pleas in Westminster. The Claimant initiated the case against the guardians of Alfred's young son, the other heir to the baronetcy, to recover possession of the Tichborne estates in Hampshire. ${ }^{84}$ The Claimant's counsel, led by William Ballantine and Harding Giffard, explained that his memory had been impaired by the stress of the Bella wreck, while affidavits from family servants and fellow officers who had served with Tichborne in the 6th Dragoon Guards prior to his disappearance emphasised the Claimant's ability to recall odd details from the past to support his cause. ${ }^{85}$ The defence counsel, led by John Coleridge, took twenty-six days to cross-examine the Claimant, during which the Claimant explained that he and Orton were old acquaintances and explicitly denied questions that asked whether he himself was Orton. ${ }^{86}$ The cross-examination was rigorous. As Ballantine would later recall, 'one prominent and most damaging result was in exhibiting the Claimant's utter ignorance of the French language, and Sir John [Coleridge]'s perfect familiarity with this and also with the classics enabled him to expose the witness upon these letter subjects in lights both startling and ridiculous'. 87

Adding to the drama was the Claimant's admission that he — as Tichborne — had seduced (with the intention to marry) his cousin, Katherine Doughty, before his departure for South America, and also implied that she had become pregnant as a result. ${ }^{88}$ Doughty, now Lady Radcliffe, later denied the allegations and rejected him as an imposter when the trial resumed in January 1872 following a four-month adjournment. ${ }^{89}$ Coleridge cross-examined just seventeen witnesses who testified against the Claimant in comparison to the 85 witnesses that were called on to support the Claimant's cause. Yet, for the jury, the strength of the former outweighed the

\footnotetext{
${ }^{83}$ Age, 27 February 1868, p.5; Everest-Phillips, 'The 1871 'Tichborne Claimant' medal', p.7.

${ }^{84}$ Colonel Frank Lushington was the legal tenant of the Tichborne estates, but the true defendants were the legal guardians of the Alfred's young son.

${ }^{85}$ Graham M. Davies, 'Identification of Familiar Faces after Long Intervals: The Tichborne Claimant Revisited', Applied Cognitive Psychology, Vol. 30, 2016, p.486.

${ }^{86}$ The Tichborne Romance, p.263.

${ }^{87}$ Mr. Sergeant Ballantine, Some Experiences of a Barrister's Life (New York: Henry Holt and Company, 1882), p.413.

${ }^{88}$ The Tichborne Romance, p.165; Sara Murphy, "No Two Men Were Ever Alike Within”: The Tichborne Trial, The Lord Chief Justice, and The Narration of Identity', Law, Culture and the Humanities, Vol. 13, no. 2, 2017, p. 251.

${ }^{89}$ Davies, 'Identification of Familiar Faces after Long Intervals', p.486; Everest-Phillips, 'The 1871 'Tichborne Claimant' medal', p.11.
} 
latter. On 4 March 1872, the jury declared that they had heard enough evidence, the Claimant's counsel construed this as a loss for the Claimant and withdrew his claim, and the case was declared a 'non-suit' on its $103^{\text {rd }}$ day. ${ }^{90}$ The presiding Chief Justice William Bovill accused the Claimant of 'wilful and corrupt' perjury and ordered his immediate arrest on charges of perjury and forgery. Bovill's contempt for the Claimant also stemmed from the fact that the Claimant had so publicly and dishonourably disclosed his sexual relations with his now-married cousin. ${ }^{91}$

After the civil trial, the now 'utterly penniless' Claimant placed an appeal in several newspapers, asking for bail and further subscriptions for his defence. ${ }^{92} \mathrm{He}$ raised enough funds to be released on bail and soon began a stumping tour of Britain, with support from Liberal MPs Guildford Onslow and George Whalley. Beginning in Alresford in May 1872, demonstrations in towns across Britain became mass ceremonies that gave the hundreds and in some cases thousands of people attending them the opportunity to see, hear, and judge the Claimant's cause for themselves. ${ }^{93}$ The key point of contention in the demonstrations was not only whether or not the Claimant was Tichborne; it was, Rohan McWilliam suggests, also about the issue of 'fair play', the belief that he should have the right to a fair trial, and a distrust in the legal profession and its peculiarly painstaking investment in quelling the Claimant's cause. ${ }^{94}$ Demonstrations came in the form of outdoor rallies and auditorium lectures. Most people who attended them were of working-class backgrounds, although it was not uncommon for middle-class supporters to attend the relatively more lavish and costly lectures. ${ }^{95}$ In speaking at many of the demonstrations, Onslow was especially thankful towards the Claimant's working-class supporters, as the Tichborne Gazette - a newspaper dedicated to the Tichborne cause - noted. ${ }^{96}$

Part of the support for Tichborne also stemmed from a response to how the Claimant had been unfairly treated in the British newspaper press. Just as mainstream press outlets continued to denounce the Claimant, publications such as the Tichborne Gazette and the Tichborne News and Anti-Oppression Journal: A Weekly Newspaper Advocating Fair Play for Every Man were established as a show of support for the Claimant, with copies sold for as little

\footnotetext{
90 Thomas, Cultivating Victorians, pp.90-91.

${ }^{91}$ Ibid, p.91.

${ }^{92}$ The Times, 27 March 1872, p.5.

${ }^{93}$ Kent, 'Victorian Self-Making', p.18; Rohan McWilliam, The Tichborne Claimant: A Victorian Sensation (London: Hambledon Continuum, 2007), pp.66-71.

${ }^{94}$ McWilliam, The Tichborne Claimant, p.74.

${ }^{95}$ Complaints were made by the Claimant's working-class supporters that ticket prices to the lectures were too expensive, and thus they were lowered. See also Tichborne Gazette, 30 July 1872, p.4; McWilliam, The Tichborne Claimant, pp.72-73.

${ }^{96}$ Tichborne Gazette, 30 July 1872, p.4.
} 
as one penny to target a mass market. ${ }^{97}$ Thus, the story of the 'rough outbacker' standing up to deep-set institutional powers became an endearing one. The mass demonstrations, fundraising rallies, songs, souvenirs, and broadside wars between supporters and detractors added to the colour of the Tichborne affair and gave his cause further traction as the criminal trial loomed.

The criminal trial of the Claimant, Regina v Castro, commenced on 21 April 1873 at the Court of Queen's Bench and lasted 188 days until 28 February 1874, becoming the longest trial in British legal history. ${ }^{98}$ Hostility amongst Britain's most reputable lawyers made it difficult for the Claimant to secure a strong defence counsel; Giffard's fees were too expensive and Ballantine was deemed ineffective following the failure of the civil trial. ${ }^{99}$ Instead, Irish barrister Edward Kenealy took on the case as head of the Claimant's counsel and conducted himself with a far more eccentric manner than his predecessors. The unprecedented longevity of the trial was largely due to the sheer amount of witnesses that were called-over 200 for each of the prosecution and the defence - and the contradictory yet highly detailed evidence they presented. ${ }^{100}$ While the prosecution was relatively restrained in its conduct, Kenealy staged a fiery defence, arguing that the Claimant was the victim of a conspiracy led by various forces within 'respectable' society, including the government, the legal establishment, and particularly the Catholic Church. ${ }^{101}$ The prosecution's cross-examination began on 20 May 1873 and lasted for two months. Witnesses included those who remembered Tichborne from childhood; those who knew Arthur Orton in Wapping; a large number of $6^{\text {th }}$ Dragoon Guards who served with Tichborne (to counter those who supported the Claimant during the civil trial); members of the Tichborne family; and witnesses from Australia and South America. ${ }^{102}$

Kenealy's address began on 22 July and lasted until 21 August, during which he refuted the evidence given by the prosecution's witnesses, particularly those who were Catholic and had attended church with Tichborne, and alleged that the case was an elaborate plot by the Jesuit order of the Catholic Church to retain control over the Tichborne estates and other valuable properties. ${ }^{103}$ He referenced French novelist Eugène Sue's The Wandering Jew (1844) in which 'a powerful religious confraternity under the guidance and leadership of the Jesuit'... 'entered

\footnotetext{
${ }^{97}$ McWilliam, The Tichborne Claimant, pp.64-65.

${ }^{98}$ Everest-Phillips, 'The 1871 'Tichborne Claimant' medal', p.10.

${ }^{99}$ Kent, 'Victorian Self-Making', p.21; Woodruff, The Tichborne Claimant, p.251.

${ }^{100}$ Everest-Phillips, 'The 1871 'Tichborne Claimant' medal', p.10.

${ }^{101}$ Davies, 'Identification of Familiar Faces after Long Intervals', p.486.

${ }^{102}$ McWilliam, The Tichborne Claimant, pp.94-97.

${ }^{103}$ Ibid p.95.
} 
into a conspiracy to deprive the descendants of the real owner of millions of money' ${ }^{104} \mathrm{Such}$ views were bolstered by George Whalley's earlier remarks that the prosecution's witnesses could be segregated into Roman Catholics, 'persons of known character' (such as military officers), and the more favourable 'miscellaneous' witnesses who testified without having ulterior motives. ${ }^{105}$

Kenealy also drew on forensic evidence techniques to exploit the prosecution and further Tichborne's cause. ${ }^{106}$ One of the many witnesses for the defence, who were called from 21 August to 27 October, was William Matthews, who created a device that superimposed photographs of the faces of the Claimant (from 1873) and of Tichborne (from 1853) to show that the position and dimensions of their facial features were identical, despite their differences in weight and build. He also measured the diameter of the iris of the eyes of two daguerreotypes of Tichborne and the Claimant, and concluded that they were the same person. ${ }^{107}$ These techniques added some (pseudo-)scientific credibility to the argument in favour of the Claimant, which had until that point relied on intuition and trust in Henriette's recognition of the Claimant. ${ }^{108}$ Nonetheless, the prosecution pointed to Tichborne's lack of ear lobes and thus the Claimant's plausibility sank further. ${ }^{109}$

Kenealy's eccentric courtroom etiquette, hyperbolic statements, and antagonistic stance toward presiding judge Alexander Cockburn did little to sway the Claimant's critics. ${ }^{110}$ Cockburn took one month to sum up the evidence, during which he pointed out the flaws in the defence, ardently objected to Kenealy's conduct, and—as Sara Murphy points out — exposed 'what law might prefer to occult: a reliance on sheer force of narrative to assemble and interpret evidence'. ${ }^{111}$ The jury concurred, and on 28 February, found that the Claimant was not Roger Tichborne, that he did not seduce Katherine Doughty (Lady Radcliffe) and nor did Roger Tichborne, and that he was indeed Arthur Orton. ${ }^{112}$ Now exposed, the Claimant was sentenced

\footnotetext{
${ }^{104}$ Maurice Kenealy, The Tichborne Tragedy (London: Francis Griffiths, 1913), p.249.

105 The Times, 1 July 1873, p.11.

106 Thomas, Cultivating Victorians, p.92.

${ }^{107}$ William Matthews, Identity Demonstrated Geometrically: With Phototype Illustrations (Bristol: J. Wright, 1876); Davies, 'Identification of Familiar Faces after Long Intervals', pp.486-487.

${ }^{108}$ McWilliam, The Tichborne Claimant, p.198.

${ }^{109}$ Davies, 'Identification of Familiar Faces after Long Intervals', pp.486-487.

${ }^{110}$ Michael Roe, Kenealy and the Tichborne Cause: A Study in Mid-Victorian Populism (Melbourne: Melbourne University Press, 1974), pp.60-61

${ }^{111}$ Murphy, "No Two Men Were Ever Alike Within"”, p.259.

112 The Tichborne Trial: The Summing Up of the Lord Chief Justice of England, Together with the Addresses of the Judges, the Verdict, and the Sentence, the Whole Accompanied by a History of the Case and Copious Alphabetical Index (London: Ward, Locke, and Tyler, 1874), p.286.
} 
to fourteen years of penal servitude. ${ }^{113}$ Kenealy's legal career also suffered, as his patent as a Queen's Counsel was revoked and he was disbarred from the Gray's Inn. ${ }^{114}$

The British newspaper press closely followed the Claimant's civil and criminal trials. While news and titbits relating to the Claimant, such as the birth of Alfred's heir in June 1867, Henriette's death in 1868, and the Claimant's subsequent bankruptcy, had already been circulating across newspapers, the civil case brought a 'new boom' to the Tichborne story, as Roe has noted. ${ }^{115}$ The Illustrated London News penned a weekly column detailing the trial's progress; The Times's day-to-day accounts of the trial flooded daily and weekly papers; and the Annual Register declared at the end of 1871 that 'the world was divided this year into the believers and the unbelievers'. ${ }^{116}$ David Wayne Thomas suggests that British newspapers with a mainstream, 'middle-class outlook' — such as The Times, the Daily Telegraph, the Standard, the Morning Post, and the Illustrated London News - tended to report on the Claimant in ways that suggested 'resistance to his case's merits'. ${ }^{117}$ McWilliam similarly adds that the Claimant found it 'difficult to get a fair hearing in the press'. ${ }^{118}$ Reports became increasingly dismissive of the Claimant as the trial dragged on, but its conclusion brought a wave of charged emotions, ranging from outrage that an imposter had been given so much attention by Britons to relief that the 'Tichborne condundrum' was no more. ${ }^{119}$ 'We breath [sic] again after that dreadful infliction', wrote the London Evening Standard, 'mankind are no longer racked with the question as to whether the heir of that venerable but somewhat unpleasant Hampshire family did or did not go to the bottom of the Bella'. ${ }^{120}$

The conclusion of the Claimant's criminal trial—and his resulting conviction—gave British newspapers freedom to comment on the case, unrestrained by the threat of libel. ${ }^{121}$ Although some working-class periodicals continued to voice support for the Claimant, including Reynolds's Newspaper and the Morning Advertiser, newspapers tended to agree with the verdict. ${ }^{122}$ The Annual Register reiterated John Coleridge's remarks that the Claimant was 'a

\footnotetext{
${ }^{113}$ Lindsay Farmer, 'Orton, Arthur', in Peter Cane and Joanne Conaghan (eds.), The New Oxford Companion to Law (Oxford: Oxford University Press, 2008), p.855.

${ }^{114}$ Diamond, Victorian Sensation, p.61.

${ }^{115}$ Roe, Kenealy and the Tichborne Cause, p.33.

${ }^{116}$ Ibid, pp.33-34; The Annual Register: A Review of Public Events at Home and Abroad, for the Year 1871 (London: Rivingtons, 1872), p.144.

117 Thomas, Cultivating Victorians, p.98.

118 McWilliam, The Tichborne Claimant, p.64.

${ }^{119}$ London Evening Standard, 8 March 1872, p.4.

${ }^{120}$ Ibid; Thomas, Cultivating Victorians, p.96.

${ }^{121}$ McWilliam, The Tichborne Claimant, p.108.

${ }^{122}$ Kent, 'Victorian Self-Making', p.30; McWilliam, The Tichborne Claimant, p.108; Thomas, Cultivating Victorians, p.98.
} 
conspirator, a perjurer, a forgerer, a slanderer, and a villain'; ${ }^{123}$ the Standard felt 'sorry' that the verdict was not a more severe one like 'hanging'; 124 and the Spectator lambasted the intelligence of those who still believed that the Claimant was anything but a 'Wapping butcher, assisted by a crazy Frenchwoman', and an 'enormous fraud'. ${ }^{125}$ Criticism of the Claimant was often associated with dismissals of Henriette Tichborne as hysterical. The Saturday Review called her a 'crazy old lady' who was determined to recognise the Claimant as Roger whether he was indeed her son or not. ${ }^{126}$ It also put forward speculation that Henriette did so as a way of getting back at the Tichborne family from whom she was estranged. ${ }^{127}$ Such depictions corresponded to the views of many in the Tichborne family, who did not approve of her background. ${ }^{128}$ However, anti-French sentiment directed at Henriette Tichborne was less pronounced than that which was directed at L'Angelier in the Smith case, as vehemence was more targeted toward Henriette's age. A commonly cited titbit in newspapers was the testimony of John Moore, Roger's butler, who remarked that if they had sent Henriette an Egyptian mummy and called it Roger Tichborne, she would have acknowledged it as her son. ${ }^{129}$

Despite - and in some ways because of — the trial's outcome, support for the Claimant continued to be widespread. Many objected to the sentence and the treatment of both the Claimant and Kenealy as harsh and vindictive. Interest in the trial and the Claimant still mobilised public opinion through songs, ballads, pro-Claimant music hall productions, figurines, medallions, and cartoons. ${ }^{130}$ Thus, supporters rallied behind Kenealy as the Tichborne movement leader. Kenealy continued to give lectures; spearheaded the 'Tichborne Release Association'; established the pro-Tichborne newspaper, the Englishman, which had a weekly circulation of 150,000 and engaged in a broadside war with The True Briton: The Avowed Enemy and Antidote to Dr. Kenealy's “Englishman”; and was elected into the House of Commons by a majority of three-thousand in $1875 .{ }^{131}$ The subsequent defeat of his motion for

\footnotetext{
${ }^{123}$ The Annual Register: A Review of Public Events at Home and Abroad, for the Year 1874 (London: Rivingtons, 1875), p.194.

${ }^{124}$ Standard, 2 March 1874, p.6.

${ }^{125}$ The Spectator: A Weekly Review of Politics, Literature, Theology, and Art (London: John Campbell, 1874), p.294.

${ }^{126}$ The Saturday Review of Politics, Literature, Science and Art: Vol. XXXIII (London: Saturday Review Office, 1872), 30 March 1872, p.401. See also Thomas, Cultivating Victorians, p.87.

${ }^{127}$ See also McWilliam, The Tichborne Claimant, p.23.

${ }^{128}$ Kent, 'Victorian Self-Making', p.19.

${ }^{129}$ Atlay, Famous Trials of the Century, p.280.

${ }^{130}$ Davies, 'Identification of Familiar Faces after Long Intervals', p.487.

${ }^{131}$ Robyn Annear, The Man Who Lost Himself: The Unbelievable Story of the Tichborne Claimant (Melbourne: The Text Publishing Company, 2002), pp.82, 198.
} 
a Royal Commission on the Claimant's case by $302-1$ in parliament shows, as Michael Diamond notes, how far the Tichborne story divided political parties from mass opinion. ${ }^{132}$

While historians have given brief attention to the gender, sexuality, and identity of the Claimant, histories of the Tichborne case have been inextricably tied to class. Roe argues that 'the Tichborne issue became one of class', both in its point of central dispute, and in determining the stances that those who followed the case took. ${ }^{133}$ 'The class confrontation on the case', writes Roe, 'was as sharp as the historian is ever likely to find'. ${ }^{134}$ Douglas Woodruff notes that many sympathised with how the Claimant was disowned by his family because he had 'disgraced' them by becoming and living like a 'common man'. ${ }^{135}$ Indeed, part of the working-class support for Tichborne - as discussed in Chapter Four of this thesis - also stemmed from the Claimant's attempts to raise funds to relieve himself from bankruptcy in 1870 by issuing the 'Tichborne Bonds'. Mortgage debentures were issued at $£ 100$ each, which the Claimant would repay with interest after obtaining his inheritance, thus allowing people to invest in and gamble on the Claimant's cause. ${ }^{136}$ 'Poor men could club together and buy part of a debenture and thus have a sporting interest in some adventure in litigation', Woodruff suggests. ${ }^{137}$

Support for the Claimant in Britain was not always class specific. While acknowledging that 'middle-class and respectable society generally dismissed sympathy for the Claimant as madness or idiocy', Thomas notes that support for the Claimant 'spanned the entire social spectrum' and that the notion that the majority of Britain's working classes favoured the Claimant lacks empirical evidence. ${ }^{138}$ Although the Claimant had strong support among working-class Britons, the contributors to his defence fund show that his financial backers were widespread. ${ }^{139}$ Roe also notes that 'respectability' had 'largely' decided against the Claimant following the civil trial, but that 'largely' is a necessary qualification because many of the Claimant's witnesses hailed from upper-middle-class backgrounds. ${ }^{140}$ Thus, Roe construes the 'Tichborne cause' as a kind of populist movement. In turn, and not wholly ignoring the Tichborne sensation's class interests, McWilliam describes the support for Tichborne as a

\footnotetext{
132 Diamond, Victorian Sensation, pp.61-62.

${ }^{133}$ Michael Roe, 'Foreword: Australia and the Tichborne Case', in Hugh Anderson (ed.). Baronet or Butcher?

The Trials of the Tichborne Claimant (Victoria: Red Rooster Press, 1999), p.ix.

${ }^{134}$ Roe, Kenealy and the Tichborne Cause, p.40.

${ }^{135}$ Woodruff, The Tichborne Claimant, p.219.

${ }^{136}$ McWilliam, The Tichborne Claimant, pp.32-33.

${ }^{137}$ Woodruff, The Tichborne Claimant, p.219.

138 Thomas, Cultivating Victorians, pp.104, 110.

${ }^{139}$ Ibid, p. 104.

${ }^{140}$ Roe, Kenealy and the Tichborne Cause, p.39.
} 
specific form of political expression. 'Tichbornism', as McWilliam calls it, was 'cross-class' but 'there is no getting away from the fact that it was largely working-class in composition', although 'Tichbornites', or Tichborne supporters, tended to employ the language of 'the people' rather than 'class'. 141

The Claimant's rise to public significance in Britain occurred not long after parliament passed the Reform Act of 1867 for England and Wales in June 1867, which gave the vote in the boroughs to all ratepaying adult male occupiers and lodgers who paid rent of at least $£ 10$ per year, reduced the property threshold in the counties, and gave the vote to agricultural landowners and tenants with very small amounts of land. ${ }^{142}$ Similar legislation followed in Scotland and Ireland in June 1868. ${ }^{143}$ The Act was intended by future Conservative Party leader, Benjamin Disraeli, as a means to secure a Conservative government by appealing to a larger constituency of working-class voters, but amendments by William Gladstone's Liberal Party made it more liberally-skewed. ${ }^{144}$ Thus, it did not work in Disraeli's favour, as the Conservatives were defeated by the Liberals at the 1868 general election. While enfranchising a large number of working-class voters, the Act also brought with it—or at least gave rise to - a growing disdain for party politics and 'opposition for its own sake', particularly among the Liberal Party's Radical wing. ${ }^{145}$ As Liberal MP John Stuart Mill wrote after the election, 'the Radicals do not care enough about a Bribery Bill' and placed their reliance 'wholly on the Ballot'. ${ }^{146}$

While the Tichborne movement employed elements of political protest consistent with radicalism, especially in its hostility to social inequality and the aristocratic elite, it was not necessarily tied to a particular political party. ${ }^{147}$ Pro-Claimant feeling, Thomas suggests, stemmed from various viewpoints ranging from Toryism to radicalism, unified by an opposition to the 'positivistic and utilitarian trends' that were defining the liberal establishment. ${ }^{148}$

\footnotetext{
${ }^{141}$ McWilliam, The Tichborne Claimant, p.240.

142 'Second Reform Act 1867', UK Parliament, https://www.parliament.uk/about/livingheritage/evolutionofparliament/houseofcommons/reformacts/overview/furtherreformacts/, accessed 2 February 2021.

${ }^{143}$ Catherine Hall, Keith McClelland, and Jane Rendall, 'Introduction', in Catherine Hall, Keith McClelland, and Jane Rendall (eds.), Defining the Victorian Nation: Class, Race, Gender, and the British Reform Act of 1867 (Cambridge: Cambridge University Press, 2000), p.5.

${ }^{144}$ Ibid.

145 McWilliam, The Tichborne Claimant, p.129. See also Kathryn Wix, 'The Second Reform Act and the Problem of Electoral Corruption', Parliamentary History, Vol. 36, no. 1, 2017, pp.64-81.

146 J. S. Mill to W. D. Christie Kent, 6 June 1868, in Francis E. Mineka and Dwight N. Lindley (eds.), The Later Letters of John Stuart Mill 1849-1973, Vol. XVI (Toronto: University of Toronto Press, 1972), p.1409.

${ }^{147}$ Rohan McWilliam, Popular Politics in Nineteenth-Century England (London; New York: Routledge, 1998), pp.69-70.

148 Thomas, Cultivating Victorians, p.111.
} 
McWilliam adds that 'Tichbornism' operated outside of liberalism 'partly because it was never respectable, but also because it really stood for a state of mind that was untheorized, sentimental, and composed of a yearning for a just social order in which the lifestyle and robust common sense of ordinary working-class people could find representation'. ${ }^{149}$ Max Everest-Phillips also contends that support for Tichborne was 'the strongest expression of popular protest to emerge between the collapse of Chartism in 1848 and the rise of socialism in the 1880s', and that public opinion favoured 'the butcher from Wagga Wagga' because his rags-to-riches cause challenged the 'legitimacy of rigid social class divides that had until just a few years earlier restricted electoral suffrage in Britain'. ${ }^{150}$ To that end, the creation of the 'Magna Charta Association'an outcropping of Tichbornism initiated by Kenealy following the criminal trial—challenged the bureaucratic state, ${ }^{151}$ held fast the Claimant's movement against an 'over-privileged, corrupt and aloof' Catholic aristocracy (represented by the Tichborne family), ${ }^{152}$ and included in its demands triennial parliaments, enfranchisement for women, and the abolition of duties on goods. ${ }^{153}$ As McWilliam suggests, 'Tichbornism' might also be considered as its own kind of 'pre-political' movement, born out of a demand for 'fair play' and a 'just social order', which entangled various conspiratorial beliefs about the forces that stood against those concerns. ${ }^{154}$

Whereas discourse on the Smith case depicted Australia and New Zealand as safe havens for criminals retreating to obscurity from the commotions of the metropole, as Chapter Two explores, the Tichborne case showed the reverse: colonial life being brought back to Britain. Empire penetrated the everyday lives of Britons in a multitude of ways, from its omnipresence in political discourse to its role in the economics of Britain's burgeoning commodity culture. Being 'at home with the Empire', as Catherine Hall argues, meant being comfortable with the idea of being imperial while maintaining a physical and cultural separation from the colonies themselves; it meant being impervious to its often inconspicuous yet no less ubiquitous and exploitative functions. ${ }^{155}$ John Plotz points out that while 'elements of foreignness' had a 'potent' allure when incorporated into British culture, their perpetual flow could also be associated with contempt and dread, particularly when they 'refused' to become commodities

\footnotetext{
${ }^{149}$ Rohan McWilliam, 'Liberalism Lite?', Victorian Studies, Vol. 48, no. 1, 2005, p.109.

${ }^{150}$ Everest-Phillips, 'The 1871 'Tichborne Claimant' medal', p.18.

${ }^{151}$ Kent, 'Victorian Self-Making', p.32.

${ }^{152}$ Everest-Phillips, 'The 1871 'Tichborne Claimant' medal', p.18.

${ }^{153}$ McWilliam, Popular Politics in Nineteenth-Century England, p.69.

${ }^{154}$ Ibid.

${ }^{155}$ Catherine Hall and Sonya O. Rose, 'Introduction: being at home with the Empire', in Catherine Hall and Sonya O. Rose (eds.), At Home with the Empire: Metropolitan culture and the Imperial World (New York, NY: Cambridge University Press, 2006), p.25.
} 
and instead kept their 'native' cultural essence. ${ }^{156}$ The Claimant's re-introduction into British life after years spent living in a rugged Australian setting might be seen as an embodiment of the 'reserve portability' of colonial artefacts. Concerns over British criminality perverting the colonies, as expressed in the Smith case, juxtaposed with metropolitan anxieties associated with the disruptive re-surfacing of colonial life 'at home', as shown by the Tichborne case. ${ }^{157}$

In examining national identity in an Australian context, Stuart Ward suggests that the idealised masculine 'bushman' stereotype represented the British race at its most versatile and pure, while conversely reminding British migrants that they were somehow of a 'lesser breed'. ${ }^{158}$ British coverage of the Tichborne case perpetuated these stereotypes. As EverestPhillips notes, the case told an 'outback shack to stately home' story that resonated with Australia's emerging national identity and helped to characterise how Britons saw the colony. ${ }^{159}$ Cassie Dawson similarly argues that the Tichborne trials 'underscored the instability of English and Anglo-Australian identities'; 'while the identification of the Claimant masked imperial anxieties about the degeneration of an English type', it also 'unwittingly confirmed the characterisation of the colonies as uncodified, lawless spaces that threatened the identity of the English subjects who travelled there'. ${ }^{160}$ For Tamara Wagner, the case solidified 'widely circulated sensational tales that commonly involved threatening returnees from overseas colonies', typified by the literary works of Dickens, Trollope, Braddon, Hardy, and Charlotte Yonge. ${ }^{161}$

Whether he was Arthur Orton or Roger Tichborne, the Claimant's manner and appearance symbolised to those who followed the case how British settlers could be changed by a life in the colonies. Roger Tichborne was slim, dark-haired, reserved, and educated before he disappeared in $1854 .{ }^{162}$ The Wagga Wagga butcher who came forward in 1865 was 'fat, uncouth, ill-spoken, and quintessentially vulgar', as Kent notes. ${ }^{163}$ Central to coverage of the case was the idea that the empire was a place of degeneration and abandonment of Victorian

\footnotetext{
156 John Plotz, Portable Property: Victorian Culture on the Move (Princeton: Princeton University Press, 2008), p.22.

${ }^{157}$ Plotz, Portable Property, p.22.

${ }^{158}$ Stuart Ward, 'Imperial Identities Abroad', in Sarah Stockwell (ed.), The British Empire: Themes and Perspectives (Malden, Oxford, and Calrton: Blackwell Publishing Ltd., 2008), p.233.

${ }^{159}$ Everest-Phillips, 'The 1871 'Tichborne Claimant' medal', p.7.

${ }^{160}$ Cassie Dawson, "“The Slaughterman of Wagga Wagga”, Imposture, National Identity, and the Tichborne Affair', Australian Literary Studies, Vol. 21, no. 4, 2004, p.7.

161 Tamara S. Wagner, 'The domestic novel's antipodes: false heirs and reclaimed returnees in Charlotte Yonge's My Young Alcides', Journal of Australian Studies, Vol. 35, no. 3, 2011, p.331.

${ }^{162}$ Everest-Phillips, 'The 1871 'Tichborne Claimant' medal', p.2. For discussion on the physical differences between the Claimant and Tichborne, see Nelson Examiner and New Zealand Chronicle, 2 October 1873, p.3. ${ }^{163}$ Kent, 'Victorian Self-Making', p.18.
} 
norms of 'civilised behaviour', and such a notion was made more pronounced by the representation of Australia as a convict colony. ${ }^{164}$ Not only were British newspapers that covered the case saturated with allusions to Australia as transformative yet degenerate, Kenealy, too, emphasised during the criminal trial how the Australian landscape was central to the Tichborne narrative. In his view, the Claimant's appearance was also the result of colonial life and a decade spent 'dealing with the carcases of sheep and bullocks', 'enjoying a purely animal existence', ridding oneself 'of any care about learning and knowledge', 'heeding nothing', and experiencing 'that sort of enjoyment that belongs to the savage'. ${ }^{165}$

Like Madeleine Smith, the Claimant's outward disregard for Victorian cultural definitions of respectability earned him notoriety in the British newspaper press that went beyond the crime that he was accused of committing. But the 'notoriety' label, discussed more comprehensively later in this thesis, also gave Smith and the Claimant support among groups across Britain and Australia who viewed the pair as culturally and politically significant, as well as endearing.

This chapter has provided an overview of how the Smith and Tichborne cases were reported on in Britain. It has argued that both cases, despite their differences in terms of the crime as the centre of the two cases, the gender of the two figures, and the length of the respective trials, were highly sensationalised in the press for the way they shocked and challenged Victorian cultural norms. Both cases were shrouded in mystery-whether Smith murdered L'Angelier and whether the Claimant was Roger Tichborne-and newspapers' attitudes toward the two cases were often polarising and heavily dependent on the day-to-day revelations of each trial. Whereas Smith earned some support from members of Britain's middle- and upper-class constituencies, as well as condemnation from working-class Glasgow newspapers, the Tichborne Claimant fostered a largely working-class political following, although class dynamics did not always account for attitudes toward the two figures, as this thesis later discusses. Newspapers brought the public shaming of Smith and the Claimant from

\footnotetext{
${ }^{164}$ McWilliam, The Tichborne Claimant, pp.193-194.

${ }^{165}$ Edward Kenealy (ed.), The Trial at Bar of Sir Roger C. D. Tichborne, Bart., in the Court of Queen's Bench at Westminster, before Lord Chief Justice Cockburn, Mr. Justice Mellor, and Mr. Justice Lush, for Perjury: Vol. IV (London: "Englishman” Office, 1877), p.296.
} 
the courtroom and into newspaper readers' homes. As Chapters Two, Three, and Four assess, the public shaming of the two figures played out in divisive, clamorous, and far-reaching ways in Australia. 



\section{Chapter Two: Identity}

'The suspicious death of Emile L'Angelier', the Bendigo Advertiser declared in 1858, has given rise to 'feelings of the most intensely and painfully interesting description, not only throughout the whole of Great Britain, but in every nation of the world'. The Sydney Morning Herald similarly declared it to be a 'remarkable fact' that the Tichborne case 'will be known in part by the whole civilised world before its finish'. ${ }^{2}$ Newspapers played a pivotal role in the dissemination of information across the British world, giving news items both 'at home' and across disparate sites of the empire an increasingly globalised audience. ${ }^{3}$ Identity construction is predicated on difference; it refers to the ways in which people define and distinguish themselves in relation to others. ${ }^{4}$ The issue of identity formed the heart of the Tichborne case. Not only did the case involve the question of whether the Claimant was a British aristocrat or an Australia outbacker, it also involved his own efforts to remove himself from particular aspects of his Australian past vis-à-vis the press's unwavering interest in it. Despite a dearth of scholarly analysis on the subject, identity also permeated the Madeleine Smith case. Akin to local fascination with the Claimant's life in Wagga Wagga, Glasgow permeated Smith's letters to L'Angelier; as a result, observers from afar saw the case as an item of foreign correspondence which resonated closer to home (in both geographic and literal senses) than others. ${ }^{5}$

This chapter aims to capture the immediacy of the trials in an Australian context. It draws on aspects of cultural (and, particularly in Smith's case, legal) history, as well as concepts of British imperialism and Australian nationalism, to examine how the cases became markers of identity in Australia. Smith became a cultural colonial icon and stimulated Scottish pride and nostalgia in the colonies through her numerous reported sightings, waxwork exhibitions, and the way her trial roused interest in the peculiar Scottish verdict of 'not proven', thus underpinning the hybridity of Scottish and Australian identities. The Tichborne case could also be used as a badge of identity and local pride, as some Australians heralded how the Claimant became a cultural icon and put Wagga Wagga and Australia 'on the map'.

\footnotetext{
${ }^{1}$ Bendigo Advertiser, 18 January 1858, p.2.

${ }^{2}$ SMH, 20 October 1871, p.4.

${ }^{3}$ Kirsten McKenzie, Scandal in the Colonies (Melbourne: Melbourne University Press, 2005), p.7; Laidlaw, Colonial Connections, 1815-1845, p.36.

${ }^{4}$ Benjamin Wilkie, The Scots in Australia, 1788-1938 (Woolbridge: The Boydell Press, 2017), p.5.

${ }^{5}$ Eleanor Gordon and Gwyneth Nair, Murder and Morality in Victorian Britain: The Story of Madeleine Smith (Manchester: Manchester University Press, 2010), p.6.
} 


\section{Madeleine Smith}

Initial coverage of the Madeleine Smith trial spanned across Australia but was particularly pronounced in Victoria. A hub for Scottish settlement, Victoria had exponentially become the most populous state following the discovery of gold there from the mid-nineteenth century. ${ }^{6}$ The city of Melbourne quickly became Australia's cultural and financial capital, and-with more periodicals produced there than in any other city - the centre of Australian journalism over the decades that followed. ${ }^{7}$ Melbourne and Geelong also served as key ports through which mail ships would supply overseas news stories, which were prominently placed in larger weekly newspapers, such as the Age, Herald, and Argus of Melbourne, and sent inland to towns and mining districts, such as Bendigo, Ballarat, Castlemaine, and Beechworth. ${ }^{8}$ The 'prolonged and exciting' Smith trial, as one report in the Australasian on Smith's apparent death would later note, was supposedly followed with 'as much interest in Melbourne as in Glasgow'.?

Crime reports of all kinds were widely read across Australia. ${ }^{10}$ 'Sensationalism, New Journalism's signature ingredient', as Anthony Laube calls it, was always present in the crime reports, 'probably the most popular reading matter right across Australia's colonial press'.11 However, unlike British newspapers, newspapers in Australia were generally reluctant to comment on Smith's guilt. Newspapers in both Australia and New Zealand copied reports from British papers that suggested that the public feeling sided with the 'not proven' verdict, but that few held the opinion that she was 'not guilty'. ${ }^{12}$ Quoting the Saturday Review, the Empire summed up the general response by noting that Smith's guilt is 'out of the reach of our righteous dealing'. ${ }^{13}$ The Sydney Morning Herald thought otherwise, and penned a poem that poked fun

\footnotetext{
${ }^{6}$ Malcolm Prentis, The Scots in Australia: A Study of New South Wales, Victoria, and Queensland, 1788-1900 (Sydney: Sydney University Press, 1983), p.66.

${ }^{7}$ Elizabeth Webby, 'Australia', in J. Don Vann and Rosemary VanArsdel (eds.), Periodicals of Queen Victoria's Empire: An Exploration (Toronto: University of Toronto Press, 1996), pp.26-27.

${ }^{8}$ Elizabeth Morrison, Engines of Influence: Newspapers of Country Victoria, 1840 Colonial Connections, 18151845: Patronage, the Information Revolution and Colonial Government 1890 (Melbourne: Melbourne University Press, 2005), pp.75, 104.

${ }^{9}$ Australasian, 19 May 1894, p.22.

${ }^{10}$ Anthony Laube, 'Adelaide, Sensationalism and the Development of New Journalism in the Early History of the South Australian Press', in Alberto Gabriele (ed.), Sensationalism and the Genealogy of Modernity: A Global Nineteenth-Century Perspective (New York: Palgrave Macmillan, 2017), p.75.

11 Ibid.

${ }^{12}$ For example, see Star (Ballarat), 5 September 1857, p.2; Star (Ballarat), 7 September 1857, p.3; SMH, 8 September 1857, p.2; Age, 14 October 1857, p.5; Empire, 24 October 1857, p.2; Bathurst Free Press and Mining Journal, 17 October 1857, p.4.

${ }^{13}$ Empire, 12 September 1857, p.3.
} 
at other newspapers' strange interest in Smith's appearance and sarcastically asked how she could be guiltless because she had 'the glow of pure innocence'. ${ }^{14}$

Rumours that Madeleine Smith had fled to the colonies following her trial contributed to a revival of public interest in the case over the late nineteenth century (and thereafter). Reported sightings of Smith in Australia began with a claim by the Ballarat Times that she had arrived in Melbourne in late 1857. ${ }^{15}$ Other Australian papers were quick to dismiss the claim by citing recent home newspaper reports that she was still in Glasgow. ${ }^{16}$ But it was not long before the Ballarat Times's critics also yielded to the continued speculation. In the eyes of those who believed the rumours, there was some logic to the notion that Smith would be sent to Australia immediately after her trial. Many papers turned to the Plymouth Journal's explanation that Australia could provide Smith a safe haven from the continued hearsay that she faced at home, that her name would be lost on colonists, and that she would be able to 'retrieve her position' in society. ${ }^{17}$ Ironically, the amalgamation of reports of Smith turning up in Australia or New Zealand every few years suggested the very opposite. Smith, a figure from 'home' for many Scots, represented a dissolving of distance between metropole and colony; her rumoured presence in the colonies underpinned colonists' appetite for sensation and showed how wellconnected they were to her case.

Soon after the Ballarat Times's reported sighting, the Auckland correspondent of the Empire reported that a 'very effeminate' man had arrived in Auckland on the Matoaka on 26 September 1859. Crowds of young men were said to have derogatorily referred to the passenger as 'Mary Ann', and — while the man's real name was not known - many onlookers claimed that it was Madeleine Smith in disguise. ${ }^{18}$ Another more well-received story came in November 1863 when it was reported that Smith had arrived in Brisbane on the Sunda. Despite conflicting with contemporaneous reports that Smith was now married and living near Linlithgow in Scotland, reports of her arrival in Brisbane were picked up by media outlets across Australia and New Zealand. Some papers commented on the confusion. The Age noted that the

\footnotetext{
${ }^{14}$ SMH, 23 September 1857, p.2.

${ }^{15}$ Glasgow Herald, 1 March 1858, p.6; Bendigo Advertiser, 25 November 1857, p.3

${ }^{16}$ For example, see Empire, 17 May 1858, p.3; Illawarra Mercury, 20 May 1858, p.3; Launceston Examiner, 22 May 1858, p.2; Armidale Express and New England General Advertiser, 29 May 1858, p.4.

${ }^{17}$ For example, see Mount Alexander Mail, 20 September 1861, p.2; Geelong Advertiser, 23 September 1861, p.3; Maitland Mercury and Hunter River General Advertiser, 24 September 1861, p.3; Illawarra Mercury, 27 September 1861, p.4; Bell's Life in Victoria and Sporting Chronicle, 28 September 1861, p.3; Sydney Mail, 28 September 1861, p.2; Goulburn Herald, 2 October 1861, p.4; Age, 4 October 1861, p.6; Cornwall Chronicle, 5 October 1861, p.3; North Australian, Ipswich and General Advertiser, 8 October 1861, p.4.

${ }^{18}$ Empire, 22 April 1861, p.2.
} 
'unpleasantly remembered' Smith was also heard of in California and the Cape of Good Hope, and the Queensland Times asked rhetorically, 'which of the two stories are we to believe?'. ${ }^{19}$ By 1864, it was widely rumoured that Smith was not only living in Brisbane, but that she had become an acquaintance of Frank Gardiner, an Australian bushranger from Scotland. Gardiner had arrived in the colony as a child in 1834 and, throughout the 1850s, gained a reputation for horse stealing and highway robbery across Victoria and New South Wales. After leading a gang, which included Ben Hall, to hold up a gold escort at the Eugowra goldfields in New South Wales in June 1862, Gardiner was reported to have fled to Apis Creek near Rockhampton in Brisbane where he worked as a storekeeper until he was traced by New South Wales police and captured in February $1864 .^{20}$

While remaining largely inconspicuous in Brisbane, it was speculated by the Geelong Advertiser not long before his arrest that Gardiner had formed a close bond with Smith. Smith was purportedly brought before the Bench of Magistrates in Brisbane in 1863 and charged with 'some minor' offence. ${ }^{21}$ Gardiner stationed himself behind her, leaned over the back of the dock, and whispered to Smith what to say to the bench. He was turned away by the attendant constable but was said to have later paid for Smith's bail. ${ }^{22}$ This story was circulated across Australia and, although dismissed by the Queensland Times as difficult to swallow, it received renewed interest after Gardiner was arrested soon after it was published. ${ }^{23}$ 'Whether these particulars were true or not', the Empire wrote, 'it is believed that the main fact was true, namely, that the bushranger was really in Queensland'. The newspaper considered it to be 'reliable authority' that the notorious Smith was the paramour of the 'still more notorious' Gardiner, but noted that the descriptions of Smith were very similar to those of Catherine 'Kitty' Brown, Gardiner's mistress, who lived with him under the alias, 'Christie'. ${ }^{24}$ Nonetheless, the Smith-Gardiner narrative gave credence to the notion that the colonies and their small settlements were

\footnotetext{
${ }^{19}$ Age, 20 November 1863, p.7; Queensland Times, Ipswich Herald and General Advertiser, 21 November 1863, p.4.

${ }^{20}$ Edgar F. Penzig, 'Gardiner, Francis (Frank) (1830-1903)', Australian Dictionary of Biography, National Centre of Biography, Australian National University, http://adb.anu.edu.au/biography/gardiner-francis-frank3589/text5561, published first in hardcopy 1972, accessed 11 January 2021; SMH, 21 March 1864, p.12.

${ }^{21}$ Empire, 21 March 1864, p.5.

${ }^{22}$ Geelong Advertiser, 18 January 1864, p.3.

${ }^{23}$ Queensland Times, Ipswich Herald and General Advertiser, 30 January 1864, p.3. For example, see Age, 19 January 1864, p.5; Star (Ballarat), 19 January 1864, p.2; Mount Alexander Mail, 20 January 1864, p.3; OMA, 21 January 1864, p.4; Empire, 23 January 1864, p.3; Adelaide Express, 1 February 1864, p.2.

${ }^{24}$ Empire, 21 March 1864, p.5.
} 
becoming safe havens for criminals, and, as the Empire concluded, it 'left a good opening for the future Australian writer of romance', or as further reports would suggest, the journalist. ${ }^{25}$

Smith was not the only figure connected to a notable criminal case to be reported throughout the late nineteenth century as leading an ordinary life in the colonies, but she was one of the most regularly sighted and recurring characters in the colonial newspaper press. The hearsay surrounding her presence in Australia shows how the spread of news to the colony was never one-directional. Newspapers allowed local and international crime reports like those of the Smith trial to reach and be widely read by readers across disparate sites of the colony, but they also functioned as mediums for the more complex dissemination of items of gossip and word-of-mouth communications. As Kirsten McKenzie notes, 'gossip of all kinds, running the full gamut from the apparently trivial to the dangerously significant, was an ever-present accompaniment to the movement of people, goods and correspondence across the imperial realm' ${ }^{26}$ Not all newspapers warmed to the sensation stirred by Smith's case, and what it said about how the British press saw the colonies. In 1869, the Argus and the Australasian used the widespread reportage of the Smith case to attack British media outlets for neglecting the colonies and giving more 'excitement and lasting curiosity' to Smith than the recent tragedies that occurred during Te Kooti's attack on Matawhero in 1868 (also known as the Poverty Bay 'massacre') in the 'distant dependency' of New Zealand. ${ }^{27}$ Nonetheless, the comparisons between Smith and colonial figures of notoriety, such as Frank Gardiner, Te Kooti, and Louisa Collins (discussed later in this section), along with the opening of wax museums featuring them and continued sightings of her being deemed newsworthy, show that Smith's actual or symbolic presence in Australia and New Zealand was long-lasting.

Many Australian newspapers accepted without question reports of Smith's death in Melbourne in 1894 and played down the notion that Smith had 'resided in this colony for several years' ${ }^{28}$ The New Zealand Herald agreed, noting that despite the 'many stories respecting what had become' of Smith, there was 'no doubt that the story published about her death in Melbourne, after having been twice married, is true'. ${ }^{29}$ Some British newspapers, such as St. James's Gazette and the Westminster Gazette, initially bought the rumour. ${ }^{30}$ Reinforcing the

\footnotetext{
25 Ibid.

${ }^{26}$ McKenzie, Scandal in the Colonies, p.17.

${ }^{27}$ Argus, 10 September 1869, p.5; Australasian, 11 September 1869, p.23.

${ }^{28}$ For example, see SMH, 11 May 1894, p.6; Inquirer and Commercial News, 10 August 1894, p.12; Advertiser (Adelaide), 28 September 1894, p.4.

${ }^{29}$ New Zealand Herald, 19 May 1894, p.1 (supp.).

${ }^{30}$ St James's Gazette, 20 November 1893, p.5; Edinburgh Evening News, 18 November 1893, p.3.
} 
notion of Australia as an ex-criminal safe haven, St. James's Gazette wrote 'that not much need be said of the remainder' of Smith's life because her retreat to the colony had enabled her to keep a low profile. ${ }^{31}$ However, British newspapers were generally less convinced by the reports of her death but were nonetheless stirred by the debate on her whereabouts and drew on their own evidence to contest the matter, with many suggesting that the 'Madeline Smith' who died in Australia was a different person altogether. ${ }^{32}$

New Zealand newspapers also participated in the speculation that Smith had retreated to Australasia, and they used these rumours to echo mixed sentiments about the nation's status as a retreat for former criminals from Britain and indeed Australia. Reports that Smith was in New Zealand had already circulated in the 1860s. One report suggested that she had arrived in Auckland in 1859; another suggested that she emigrated to the country with her apparent husband, 'the boy Jones', who was famous for breaking into Buckingham Palace and Windsor Castle several times between 1838 and $1841 .{ }^{33}$ But it was the Temuka Leader's claim in 1880 that Smith has been living in New Zealand 'for the last seven or eight years' and had been seen in South Canterbury and the West Coast of the South Island that garnered significant attention in the press. ${ }^{34}$ Newspapers across the country expressed displeasure with the story, dismissed it as 'highly improbable', or - in the case of the Auckland Star - gathered local intelligence from Auckland residents who apparently knew her personally and claimed that she was actually residing in London. ${ }^{35}$ A further 1886 report in the Wanganui Herald that Smith 'lives in this colony and on this coast' and an 1897 article in the New Zealand Herald claiming that an inconspicuous Smith died 'a year or two ago' in the Wanganui district suggest that the rumours had an enduring life of their own. ${ }^{36}$

While many historians agree that Smith died in poverty in Brooklyn in 1928, the unusual excitement and wild rumours surrounding her later life and apparent death in the colonies

\footnotetext{
${ }^{31}$ St James's Gazette, 20 November 1893, p.5.

${ }^{32}$ For example, see Globe, 24 November 1893, p.7; Newcastle Evening Chronicle, 25 November 1893, p.4; Aberdeen Evening Express, 25 November 1893, p.2; St James's Gazette, 25 November 1893, p.13. St James's Gazette regretted its 20 November 1893 report, asking rhetorically, 'who can put his faith in telegrams nowadays?'

${ }^{33}$ Empire, 22 April 1861, p.2; 21 December 1867, p.2.

${ }^{34}$ Evening Star, 22 January 1880, p.2.

${ }^{35}$ Auckland Star, 4 February 1880, p.2. For other examples, see Evening Star, 22 January 1880, p.2; Auckland Star, 3 February 1880, p.2; Nelson Evening Mail, 11 February 1880, p.2; Cromwell Argus, 17 February 1880, p.6; Inangahua Times, 23 February 1880, p.2.

${ }^{36}$ Wanganui Herald, 11 June 1886, p.3; New Zealand Herald, 5 June 1897, p.1 (supp.).
} 
continued well into the twentieth century. ${ }^{37}$ In 1898, Adam Melville took some pride in having seen Smith twice in his life; first, while watching her being taken to Calton Hill gaol in Edinburgh amidst her trial, and second, when she visited his Melbourne library in early 1870, accompanied by the Australian poet Adam Lindsay Gordon not long before his suicide. ${ }^{38}$ 'The woman was Madeline [sic] Smith under a different name, older, and fuller in the face, but the eye was the same, fixed and intense in its gaze. ${ }^{39}$ The rumour that Smith had escaped to Australia following her trial continued to resonate until British reports of her death in the United States in 1928 suggested otherwise. ${ }^{40}$

Waxworks were another way that Smith became a kind of folklore icon beyond Britain and allowed those hopeful to obtain a glimpse of her (or thereabouts) to satisfy their curiosities. By the mid-nineteenth century, Madame Tussaud's was not merely an exhibition but a cultural institution that attracted local, national, and overseas visitors, and helped shape perceptions of well-known contemporary and historical figures. ${ }^{41}$ Although it sought to 'adhere to the new forms of respectable leisure' and 'circulated a conservative notion of the past' with monarchy, nation, and empire, its Chamber of Horrors display_as Billie Melman notes-drew on the Victorian appetite for sensation and scandal, combined 'repulsion, apprehension, and fear' with 'attraction and delight', and brought the museum to a wider constituency of all ages and classes. ${ }^{42}$ Figures in the museum were made to look as accurate as possible, and recreations in the Chamber of Horrors often used clothing and items from the scenes of the crime to do so. ${ }^{43}$ Waxworks invited the public to invade upon the space of well-known figures and talk freely about them as if they were in their presence. ${ }^{44}$ Such displays were not without controversy; their critics, including author Charles Dickens and the satirical Punch magazine, argued that the

\footnotetext{
${ }^{37}$ For example, see Mary S. Hartman, 'Murder for Respectability: The Case of Madeleine Smith', Victorian Studies, Vol. 16, no. 4, 1973, p.400; William W. J. Knox, The Lives of Scottish Women: Women and Scottish Society 1800-1980 (Edinburgh: Edinburgh University Press, 2006), p.66; Douglas MacGowan, The Strange Affair of Madeleine Smith: Victorian Scotland's Trial of the Century (Edinburgh: Mercat Press, 2007), p.140; Brian Jenkins, Madeleine Smith on Trial: A Glasgow Murder and the Young Woman Too Respectable to Convict (North Carolina: McFarland \& Company, Inc., 2019), p.186.

${ }^{38}$ A. G. Melville, 'The book trade in Australia since 1861', in Library Association of Australasia, Proceedings of Sydney Meeting, 1898 (Sydney: Hennesey, Harper \& Company, Printers and Publishers, 1899), pp.113-114. See also Australian Star, 7 October 1898, p.7; 15 October 1898, p.5.

${ }^{39}$ Melville, 'The book trade in Australia since 1861', pp.113-114.

${ }^{40}$ For example, see Dubbo Dispatch and Wellington Independent, 16 January 1909, p.8; Argus, 31 January 1925, p.7; Australasian, 9 June 1928, p.6; Daily Telegraph (Sydney), 14 May 1929, p.6.

${ }^{41}$ Barbara Gribling, "A Visit to Madame Tussaud's": Capturing a Child Audience in Victorian and Edwardian England", Journal of the History of Childhood and Youth, Vol. 11, no. 3, 2018, p.422.

${ }^{42}$ Billie Melman, The Culture of History: English Uses of the Past 1800-1953 (Oxford: Oxford University Press, 2006), p.31.

${ }^{43}$ Gribling, "AA Visit to Madame Tussaud's", p.422.

${ }^{44}$ Pamela Pilbeam, Madame Tussaud and the History of Waxworks (London: Hambledon Continuum, 2006. First published in 2003), p.227.
} 
museum glorified crime, while its defenders argued the opposite. ${ }^{45}$ However, what was not disputed was the museum's popularity, not only because of its centrality in London but through its various colonial imitations throughout the empire. ${ }^{46}$

England's libel laws prevented Smith from featuring among Britain's most notorious murderers at Madame Tussaud's Chamber of Horrors, but Australian wax proprietors saw no issue in displaying her at their various exhibitions, beginning with 'Madame Lee's Waxwork Exhibition' on Bourke Street, Melbourne, in December $1857 .{ }^{47}$ As the colonial counterpart to Madame Tussaud's, the exhibition was owned by circus artist and ballet dancer, Madame Lee, who displayed Smith as a 'full length figure' with 'correct likeness' and wearing a facsimile dress of the one she wore at her trial. ${ }^{48}$ In 1858 , the museum was sold to wax modeller, Ellen Williams, and it later became known as 'Madame Sohier's Waxwork Exhibition' after Williams married Philemon Sohier, the owner of the 'Phrenological Museum' in Melbourne, in 1859. ${ }^{49}$ The wax exhibition included figures of both local and global prominence, and-like Madame Tussaud's - featured its own 'Chamber of Horrors' section: a 'criminals' room that appealed to spectators from across Victoria. Commenting on its popularity, the Melbourne Punch wrote sardonically yet with some veracity that the Sohier waxworks was 'a colonial industry', whereby 'the more murders, the more it thrives' and that the manufacturer 'always keeps a lot of bodies on hand, and immediately upon a malefactor being hanged pops a head upon one of them, advertises it, and in rush the public' ${ }^{50}$ Smith's figure was placed alongside a slew of Australian criminals that included Scottish-Australian bushranger, Captain Melville, and Chong Sigh and Hing Tzan (the clients and convicted murderers of Sophia Lewis, a sex worker, in the Chinese district of Melbourne in 1857). ${ }^{51}$ According to the museum's 1862 catalogue, Smith needed little introduction, for the 'immense notoriety' of her trial still reverberated an all-important lesson that a 'ton of Religion in the head is not worth a grain in the heart' ${ }^{52}$

\footnotetext{
${ }^{45}$ Melman, The Culture of History, p.63.

${ }^{46}$ Pamela Pilbeam, 'Madame Tussaud and the Business of Wax: Marketing to the Middle Classes', Business History, Vol. 45, no. 1, 2003, pp.6-22.

${ }^{47}$ Mimi Colligan, 'Waxworks shows and some of their proprietors in Australia, 1850s-1910s', Australasian Drama Studies, No. 34, April 1999, p.89.

${ }^{48}$ Argus, 28 December 1857, p.8.

${ }^{49}$ Argus, 21 April 1859, p.4; 'The Waxworks', National Portrait Gallery, https://www.portrait.gov.au/content/556, accessed 8 December 2020.

${ }^{50}$ Melbourne Punch, 6 January 1867, p.6.

${ }^{51}$ Age 20 April 1858, p.1.

${ }^{52}$ Catalogue of Madame Sohier's Australian Waxworks Exhibition, Great Bourke Street East, Melbourne (Melbourne: Clarson, Shallard, \& Co., 1862), p.14.
} 
The Sohiers opened a second branch in Sydney in 1863, sold their Melbourne museum to German anatomical modeller, Maximilian Kreitmayer, in 1869, and travelled to England to secure new belongings for their exhibitions but were lost at sea on their return voyage on the illfated City of Sydney in $1870 .{ }^{53}$ The Sydney branch continued under son Edwin Sohier until the 1890s, while the Kreitmayer family managed the Melbourne waxworks until its closure in 1911. ${ }^{54}$ The Smith figure was a mainstay at the Melbourne waxworks for the rest of the nineteenth century, and was later accompanied by the wax replica of Louisa Collins, a New South Wales native dubbed the 'Lucretia Borgia of Botany', who was found guilty of poisoning and murdering her two husbands, Charles Andrew in 1887 and then Michael Collins in $1888 .{ }^{55}$ Collins was the last person to be publicly hanged in New South Wales. ${ }^{56}$ The Sohier and Kreitmayer families were not alone in their interest in Smith. A travelling exhibition titled 'The Great Waxwork Exhibition' gave Smith top billing as one of its 'notorious criminals' in shows that spanned Adelaide, Mount Gambier, Hamilton, Wangaratta, Beechworth, Rockhampton, Ipswich, and Wollongong from 1863 to $1867 .{ }^{57}$ Disaster struck the travelling exhibition at its Beechworth leg when a fire ravaged the Lone Star Hotel on 16 October 1865, destroying $£ 600$ of wax work figures exhibited at the hotel that day. The replica of the 'notorious' Smith was the only figure that was salvaged. ${ }^{58}$ Later, Italian wax proprietor Signor Ghiloni toured Australia throughout the 1870 s with his collections of figures 'who have rendered themselves notorious in crime both at home and in the colonies', which included Smith, the Kelly brothers, and the 'Burgess gang' known for the Maungatapu murders in New Zealand in 1866. ${ }^{59}$

Australia's curious fascination with the macabre also carried over to the stage. Smith's wax replica became a principal character in a theatre play, 'The Chamber of Horrors', by George Fawcett at the Princess's Theatre in Melbourne in 1863. The play's story centred on the wax

\footnotetext{
${ }^{53}$ Empire, 21 December 1863, p.5; Catherine Bishop, Minding Her Own Business: Colonial Businesswomen in Sydney (Sydney: NewSouth Publishing, 2015), pp.197-198.

${ }^{54}$ Bishop, Minding Her Own Business, p.198; Public Opinion, 21 January 1915, p.8.

${ }^{55}$ Smith appears in Catalogue of Madame Sohier's Waxworks Exhibition, Bourke Street East, Melbourne, and Pitt Street, Sydney (Melbourne: Wilson \& Mackinnon, Printers, 1865) and Catalogue of Madame Sohier's Waxworks Exhibition, Bourke Street East, Melbourne, and Pitt Street, Sydney (Melbourne: Wilson \& Mackinnon, Printers, 1866). See also The Herald (Melbourne), 10 January 1880, p.3; Argus, 1 March 1899 , p.7. ${ }^{56}$ Susan Chenery, 'They'll never hang a woman': Louisa Collins thought she'd be spared', The Guardian, https://www.theguardian.com/books/2018/sep/25/theyll-never-hang-a-woman-louisa-collins-thought-shed-bespared, accessed 23 July 2020.

${ }^{57}$ For example, see South Australian Register, 4 February 1863, p.1; Border Watch, 17 December 1864, p.3; Hamilton Spectator and Grange District Advertiser, 11 January 1865, p.3; Hamilton Spectator and Grange District Advertiser, 14 January 1865, p.2; OMA, 25 May 1865, p.2;

Northern Argus, 8 September 1866, p.2; Queensland Times, Ipswich Herald and General Advertiser, 25 September 1866, p.2; Illawarra Mercury, 16 October 1866, p.2; OMA, 20 April 1867, p.3.

58 OMA, 19 October 1865, p.2.

${ }^{59}$ Queensland Times, Ipswich Herald and General Advertiser, 7 June 1870, p.3.
} 
figures of Smith and Marie Manning, who was executed in London for the murder of her lover in 1849, falling in love with their custodian, Philemon Sohier (played by Fawcett), who tells each of them in private that he loves only them. When they discover the truth, they plot to kill him but he instead smites both of them and then commits suicide at the horror of his crime. ${ }^{60}$ According to the Argus, the comedic production was well-received both commercially and critically, and 'appeared thoroughly to amuse the audience'. ${ }^{61}$ The English-born Fawcett née Rowe was a popular actor-writer on the Melbourne theatre scene known for dramatizing the works of Dickens and for his involvement in cheap, undemanding burlesques, comedies, and sensation dramas that drew on the current events of the day. ${ }^{62}$ Fawcett left for Otago in December and showcased the production at a 'crowded' Princess Theatre in Dunedin in January 1864. ${ }^{63}$ The Otago Daily Times called it 'one of the most amusing sketches produced' at the theatre and wrote that Marian Dunn, an actor in Fawcett's company who portrayed Smith in all the 'Chamber of Horrors' productions, won 'well-merited applause'. ${ }^{64}$ A burlesque variation of the play in which Fawcett played Madame Tussaud (instead of Sohier) was later shown at the Theatre Royal in Auckland in November 1864 to 'eminent success' ${ }^{65}$ But the play's vociferous reception was also cause for some concern because, as the Otago Daily Times reported, it represented a growing trend of dramatists procuring 'a story or a drama which will work upon the morbid sensibilities of their readers or audiences' and writing 'nothing better' than 'sensational pieces'. 66

Pierre Nora has categorised museums with monuments and statues as 'environments of memory' devoted to the idea of 'maintaining by artifice and by will a society deeply absorbed in its own transformation and renewal'. ${ }^{67}$ Whereas statues evoke feelings of nostalgia for particular groups, imposing a 'permanent memory on the very landscape within which we order our lives', colonial wax museums like those that featured Smith were less fixed in place, more entertaining than commemorative, and—as Madame Tussaud's typified—-more rooted in the

\footnotetext{
${ }^{60}$ Bell's Life in Victoria and Sporting Chronicle, 3 October 1863, p.2. See also Argus, 30 September 1863 , p.8. Manning and her husband, Frederick, were executed for the murder of her lover, Patrick O'Connor.

${ }^{61}$ Argus, 28 September 1863, p.5.

${ }^{62}$ Mimi Colligan and Veronica Kelly, 'George Fawcett', in Philip Parsons and Victoria Chance (eds.), Companion to Theatre in Australia (Sydney: Currency Press, 1995), p.222; Lisa Warrington, 'We are amused: Theatre comes to Dunedin, December 1861 - April 1862', Australasian Drama Studies, 2013, Vol. 62, p.43.

${ }^{63}$ The Herald (Melbourne), 3 December 1863, p.2; Otago Daily Times, 9 January 1864, p.4.

${ }^{64}$ Otago Daily Times, 9 January 1864, p.4. See also The Herald (Melbourne), 28 September 1863, p.3; Daily Southern Cross, 2 November 1864, p.1.

${ }^{65}$ New Zealand Herald, 3 November 1864, p.1.

${ }^{66}$ Otago Daily Times, 6 January 1864, p.4.

${ }^{67}$ Pierre Nora, 'Between Memory and History: les lieux de memoire', Representations, No. 26, 1989, p.12.
} 
'liberation of the observer from all normal rules of politeness' ${ }^{68}$ In a study of the monuments of Robert Burns and William Wallace in colonial Ballarat, Benjamin Wilkie suggests that statues reflect cultural and political identities. Colonial Scots saw the British Empire as 'a stage upon which the credibility and authenticity' of Scottish 'symbols and values could be asserted', such as 'self-help, thrift, diligence, independence, and respectability' ${ }^{69}$ While Burns and Wallace might be seen as more commemorative, permanent, and 'imperial' representatives of Scottish national identity and collective memory in Australia, the relatively more uncanny, lifelike wax reproductions of Smith served to frighten, bewilder, and warn observers about the dangers of deviating from Victorian social norms. ${ }^{70}$

The nationalities of those who visited the Madeleine Smith waxwork can only be speculated but the notion that Smith had literally earned her place alongside exhibits of colonial criminals suggests that wax museum patrons were well-acquainted with the case. Many saw no problem with combining a local criminal with a British one, thus amplifying the close connection between colony and metropole and illuminating the hybridity of Scottish, British, and Australian identities. Some patrons may have been motivated to visit by the lure of her appearance and character; for others, seeing Smith in near-lifelike form might have evoked their own reminiscence of the time and place they first heard and read about the case, whether in Australia, Scotland, or elsewhere. As one contributor to the Daily News in Perth wrote in 1924 on viewing a 'perfect' replica of Smith at the Melbourne Waxworks, 'I am a native of Edinburgh, and during my boyhood days I frequently heard my parents and their friends converse about the sensational trial of the Scottish beauty, Madeline [sic] Smith' ${ }^{71}$

Most newspapers across Australia saw the Smith case as less of a Scottish than a British one. In some instances, the entanglement of the colonies with a 'sensation' like the Smith case could also serve as a foundation for asserting or challenging concepts of national identity. 'Identity' is not a fixed paradigm, and notions of Scottishness and Britishness are not mutually exclusive. Settlers could be proudly Scottish and proudly Australian, and Australian coverage of the Smith case showed how fluid the concepts were in a colonial context. ${ }^{72}$ Indeed, Glasgow,

\footnotetext{
${ }^{68}$ Pilbeam, Madame Tussaud, p.227.

${ }^{69}$ Wilkie, The Scots in Australia, pp.77-79.

${ }^{70}$ Ben Wilkie, 'Scottish Identity in Stone: Statues of Robert Burns and William Wallace in Ballarat', Victorian Historical Journal, Vol. 84, no. 2, 2013, p.298.

${ }^{71}$ Daily News (Perth), 19 August 1924, p.5.

${ }^{72}$ Stephen Jackson, Religious Education and the Anglo-World: The Impact of Empire, Britishness, and Decolonisation in Australia, Canada, and New Zealand (Leiden; Boston: Brill, 2020), p.8. See also Cliff Cumming, 'Scottish National Identity in an Australian Colony', The Scottish Historical Review, Vol. 72, no.
} 
the 'second city' of the British Empire after London, also permeated Smith's letters and the headlines about the trial in the colonies, thus giving credence to the idea that the case resonated with observers from afar. Gordon and Nair have discussed how Smith was 'bound up in the very fabric of the city'; her father and grandfathers - prominent architects as they were-'had literally made significant parts of it' ${ }^{73}$ The case evoked memories of the city for some Scottish migrants to Australia. One letter to the editor of the Bendigo Advertiser used the lack of national stereotypes in discussions of the Smith case to decry geographical distinctions of other criminals based on country and creed. Just 'because there was a Madeline [sic] Smith' [sic] did not mean that 'modesty and chastity are graces unknown in Glasgow', the author asserted. ${ }^{74}$ Another migrant to Adelaide, J. S. O. Allen, recalled seeing a book 'with the whole account' of the trial when she arrived in South Australia. She wrote,

Glasgow, like all large cities, had its grievances and distresses in some of the dark and destitute parts... One had only to read the newspapers to learn that evil was not confined to the poor and degraded. Close to where I then lived the daughter of people in high rank was arrested for giving her lover poison. Her name was Madeleine Smith. So widespread was the interest felt that people chipped bits of the stone window-sill, where she passed the poison to him which caused his death. ${ }^{75}$

As Tanja Bueltmann notes, 'there was clearly meaning in the occasional bout of nostalgia' for Scottish migrants. ${ }^{76}$ News of the Smith case could evoke feelings of connection to 'home', while gossip surrounding her real or imagined presence in the colonies suggest that assertions of one's 'Scottishness' could be more pronounced when removed from 'home' and transplanted to the colonies. In the same way that statues of cult figures, such as Burns and Wallace, gave the Australian landscape social and cultural significance for Scottish migrants, reported sightings of Smith, testimonies of figures like Allen, and museums featuring Smith show how Scottish identity could be reimagined within a colonial setting. ${ }^{77}$

Where colonial coverage of the Smith trial centred most explicitly on its Scottish nature was through debate over the Scottish legal system and the merits of the 'not proven' verdict.

193, 1993, pp.22-38; Brad Patterson, Tom Brooking, Jim McAloon, Rebecca Lenihan, and Tanja Bueltmann, Unpacking the Kists: The Scots in New Zealand (Montreal \& Kingston: McGill-Queen's University Press, 2013); Valerie Wallace, Scottish Presbyterianism and Settler Colonial Politics: Empire of Dissent (Cham: Palgrave Macmillan, 2018); Wilkie, 'Scottish Identity in Stone', pp.279-302.

${ }^{73}$ Gordon and Nair, Murder and Morality, p.6.

${ }^{74}$ Bendigo Advertiser, 8 November 1858, p.3.

75 J. S. O. Allen, Memories of My Life: From My Early Days in Scotland Till the Present Day in Adelaide (Adelaide: J. L. Bonython \& Co., "The Advertiser" Office, 1906), p.33.

76 Tanja Bueltmann, Clubbing Together: Ethnicity, Civility and Formal Sociability in the Scottish Diaspora To 1930 (Liverpool: Liverpool University Press, 2014), p.7.

${ }^{77}$ Wilkie, The Scots in Australia, pp.47, 74. 
Because Australia and New Zealand adopted the English legal system as their official statutes, the influence of Scots law on Australia and New Zealand has traditionally been an understudied field in legal history, owing to the assumption that Scottish involvement in the law in both colonies was 'disproportionately minor' ${ }^{78}$ Nonetheless, in assessing what Brad Patterson, Tom Brooking, and Jim McAloon have called the 'subtle Scottish influences' in the shaping of colonial law in New Zealand and indeed Australia, it is clear that there was some conjecture, intrigue, and debate in the colonial press on the uniqueness of Scots law and its possible application in a colonial context. ${ }^{79}$ Although newspapers tended to be reticent in how they viewed the Smith verdict, many in Australia and New Zealand nonetheless used to it to shed light on the peculiarities of Scots law. By calling on newspaper contributors to debate, defend, and explain the intricacies of the Scottish legal system, news about the Smith case showed how Scots law could serve as a marker of Scottish identity.

Much of the initial reaction to the Smith verdict among colonial media outlets was best captured in the Bendigo Advertiser's response to a widely disseminated 1857 article in The Times. 'Those who understand what is implied by the Scotch verdict "Not Proven", the paper wrote, 'will readily agree with the Times, that 'Madeline [sic] Smith goes forth free from the penalties of the law, and that is all." 80 The Mount Alexander Mail went further in explaining exactly what was implied by the verdict, noting that because her innocence was not established, Smith 'leaves the court with a tainted name' and confronts a future that will be 'darkened' by 'recollections of a dreadful past'. ${ }^{81}$ Australian papers tended to comment on how most people following the trial concurred with its verdict, with the Sydney Morning Herald noting that there was 'universal agreement' and the South Australian Register and the Launceston Examiner calling it 'logical' ${ }^{82}$. The Star was most forthright in reporting that 'public opinion coincides with the verdict' but the 'general belief' was that Smith was guilty. ${ }^{83}$ However, it was not until later in the century that more marked, albeit retrospective, opinions on Smith's guilt were publicised in Australia and New Zealand.

\footnotetext{
${ }^{78}$ Valerie Wallace, 'Scots law and British settler colonialism: the debate on criminal procedure in nineteenthcentury New Zealand' (paper presented at the Australian and New Zealand Law and History Society Conference, University of Auckland, Auckland, 9 December 2020), unpublished paper; Prentis, The Scots in Australia, p.166. See also Patterson, Brooking, McAloon, Lenihan, and Bueltmann, Unpacking the Kists, p.268.

${ }^{79}$ Patterson, Brooking, McAloon, Lenihan, and Bueltmann, Unpacking the Kists, p.266.

${ }^{80}$ Bendigo Advertiser, 5 September 1857, p.2.

${ }^{81}$ Mount Alexander Mail, 7 September 1857, p.2.

${ }^{82}$ SMH, 8 September 1857, p.2; Launceston Examiner, 8 September 1857, p.4; South Australian Register, 10 September 1857, p.2.

${ }^{83}$ Star (Ballarat), 5 September 1857, p.2. See also Star (Ballarat), 7 September 1857, p.3.
} 
It was not uncommon for nineteenth-century reports of legal cases in Australia and New Zealand to refer to the 'not proven' verdict, often when a case resulted in a dismissal or if it appeared that the verdict should have been used instead of an acquittal or conviction. In Australia, there were scatters of local criminal and civil cases that were variously influenced by or at least contemporaneous with the Smith trial, particularly in rousing debate over the application of 'not proven'. In Waverley, Victoria in 1857, a farmer accused a local man of shooting his chickens, but it could not be proven. The case was dismissed and the farmer was fined and accused of 'fowl play', as Bell's Life in Sydney and Sporting Chronicle wrote humorously, noting the coincidental parallels between the case and the recent Smith trial. ${ }^{84}$ Similarly, after prisoners escaped from a lock-up in Talbot in Victoria in 1859, there was some consensus in the press that charging the prison staff for malpractice was unnecessary and that a 'trial by public opinion'—as Smith's 'not proven' verdict suggested-was a more fitting punishment. ${ }^{85}$ It was also noted that members of the jury during the Smith case were exempted from further services for the heavy tax upon their time and attention that the case had placed upon them. In Sydney in 1857, a long-running land dispute called the 'Newtown Ejectment Case' came to an end after a 30-day trial and the jury was rewarded with a similar exemption. ${ }^{86}$

It was not long before newspapers penned entire columns that weighed up the benefits of the unique Scottish verdict. In 1860, Ballarat's Star proposed that the verdict should be adopted by Australia's criminal jurisprudence because, although 'not proven' allowed the accused to escape conviction, it still (at least according to the Star) meant that they could be liable to a renewal of proceedings 'should facts turn up afterwards', which the English verdicts of 'guilty' and 'not guilty' were too rigid to account for. ${ }^{87}$ The newspaper continued to reiterate its support for the verdict years later. ${ }^{88}$ South Australia's Border Watch similarly wrote that 'not proven' was a modest verdict that met the difficulty of doubtful cases because 'guilty' and 'not guilty' were beyond the capability of fallible morals to declare certain. ${ }^{89}$ Such feelings were not

\footnotetext{
${ }^{84}$ Bell's Life in Sydney and Sporting Chronicle, 19 September 1857, p.3.

${ }^{85}$ Maryborough and Dunolly Advertiser, 17 June 1859, p.2; Age, 21 June 1859, p.2.

${ }^{86}$ SMH, 21 September 1857, p.6.

${ }^{87}$ Star (Ballarat), 30 July 1860, p.2. Contrary to the Star's assertion, those acquitted in Scotland under the 'not proven' verdict were protected by the principle of double jeopardy, which prohibits a person from being re-tried for the same offence. See Samuel Bray, 'Not Proven: Introducing a Third Verdict', The University of Chicago Law Review, Vol. 72, no. 4, 2005, p.1301; Peter Duff, 'The Scottish Criminal Jury: A Very Peculiar Institution', Law and Contemporary Problems, Vol. 62, no. 2, 1999, p.192.

${ }^{88}$ See Star (Ballarat), 28 October 1867, p.2.

${ }^{89}$ Border Watch, 30 October 1863, p.2.
} 
shared by the Launceston Examiner, which corrected the misconception that a person dealt a 'not proven' verdict could be retried for the same offence..$^{90}$

Later in the nineteenth century, it appears that the Smith case strongly resonated in the collective memory of some Australian legal practitioners, as one 1878 larceny case at the police court in Young, New South Wales, suggests. Finding that the case against the defendant, James Daley, lacked evidence, the police magistrate, Sergeant Cornett, allowed it to be withdrawn, rather than dismissed, and explained that the circumstances would have, in a Scottish court, called for a verdict of 'not proven'. The Burrangong Argus criticised Cornett's actions, noting that the magistrate had evidently used the 'celebrated' Smith case as a precedent in the administration of English criminal law, had resorted to the Scottish 'middle course', and had thus ignored the English rule that the accused person has to be found either guilty or not guilty. ${ }^{91}$ Another correspondent named 'Marsdens' similarly pointed out Cornett's apparent indeterminacy, telling him that 'in the colony of New South Wales he is paid to administer English law' and that if Smith had been tried in an English court, she would have 'inevitably' been found guilty. ${ }^{92}$

Smith's synonymity with 'not proven' meant that her case became a fixture in discussions on the merits of the verdict, particularly after another Scottish murder trial - that of Alfred Monson - also resulted in the 'not proven' verdict. While Madeleine Smith was 'still the frequent theme of conversation', as Perth's Inquirer \& Commercial News remarked, 'no trial has created so widespread, or so keen an interest' as the Monson trial. ${ }^{93}$ In 1893, Monson, a tutor, was accused of murdering his former pupil, Cecil Hambrough, while on a hunting trip near Ardlamont House in Argyll. The 'Ardlamont mystery', as it became known, received extensive coverage in the colonies, and it renewed interest in the Smith case. The British press tended to concur with the verdict, although Monson was less receptive and felt that he would have been found 'not guilty' had he been tried in an English court. ${ }^{94} \mathrm{He}$ would later go on to sue Madame Tussaud's museum in London, for libel in 1894, for depicting him as a waxwork holding a gun and insinuating that he was a murderer in its 'Chamber of Horrors' exhibition. ${ }^{95}$

\footnotetext{
${ }^{90}$ Launceston Examiner, 4 February 1860, p.2.

${ }^{91}$ Burrangong Argus, 20 April 1878, p.2.

92 Ibid, 1 May 1878, p.3.

${ }^{93}$ Inquirer and Commercial News, 9 February 1894, p.19.

${ }^{94}$ John Gray Wilson, Not Proven (London: Secker \& Warburg, 1960), pp.172-173.

${ }^{95}$ Harvard Law Review, Vol. VIII. 1894-95 (Cambridge, MA: The Harvard Law Review Publishing Association, 1895), pp.495-496.
} 
In Australia, the Argus wrote that the Monson trial had more interest in Scotland 'than any other celebrated case of the century, except perhaps that of Madeleine Smith' ${ }^{96}$ Unlike other Australian newspapers, the Maryborough Chronicle was swift in criticising reports of Smith's death in Australia in 1894 and insinuated that the excitement stirred by the recent Monson case might have been the reason for such rumours. The Smith trial 'made the future' of the late Lord President Inglis, and 'possibly there is in store similar honours for the advocates engaged in the Monson case'. The paper wrote, 'the forthcoming [Monson] trial will excite as widespread interest as that which attached to the charge against the lovely Madeline [sic] Smith'. ${ }^{97}$ The Maryborough Chronicle's suggestion had some veracity, as the particular interest in the Monson case among Western Australian papers, such as the Inquirer \& Commercial News, was not coincidental. Edward Scott, Monson's accomplice, was rumoured to have fled to Western Australia's goldfields following Hambrough's death. ${ }^{98}$ However, his eventual surrender to police in London quickly quashed the rumours. ${ }^{99}$

The commentary on the 'not proven' verdict ignited by the Smith case and reignited by cases like Monson's shows that debates about Scots law were not legally or geographically tied to Scotland but were transplanted elsewhere. ${ }^{100}$ Press reports and letters to newspaper editors calling for the colonies to adopt the 'non proven' verdict — or retrospectively asserting that a verdict tantamount to 'not proven' should have been applied - appeared regularly in Australian and New Zealand newspapers, particularly when a local case ended in an unsatisfying acquittal or conviction. The Smith and Monson trials raised awareness of the verdict and illustrated how the distinctiveness of Scottish criminal procedure could be used as a marker of Scottish identity, as expressed in newspaper debates. The legal debates, combined with sightings, wax productions, plays, and personal stories about Smith throughout Australian newspapers, show how well-informed readers were in the case and the distinctive aspects of Scottishness that came with it. Whereas Smith's case evoked a connection to 'home' for British settlers interested in the case, the Tichborne Claimant's case - as the later part of this chapter discusses-evoked local feelings of pride that were more rooted in Australia's nascent nationalism.

\footnotetext{
${ }^{96}$ Argus, 3 February 1894, p.9.

${ }^{97}$ Maryborough Chronicle, Wide Bay and Burnett Advertiser, 13 January 1894, p.3.

${ }^{98}$ The Inquirer and Commercial News, 9 February 1894, p.19.

${ }^{99}$ Launceston Examiner, 7 April 1894, p.5.

${ }^{100}$ Wallace, 'Scots law and British settler colonialism'.
} 


\section{The Tichborne Claimant}

In an 1876 review of the Tichborne trials, Tichborne supporter and publicist Robert Gurnell wrote that as 'complicated and voluminous as the Tichborne case is in the immensity of its details, it is simply in its essence a mere question of Identity! ${ }^{101}$ While the Claimant's case called into question his identity as Tichborne, it also highlighted societal differences associated with class, gender, race, and nationality. Whereas Smith's case in Australia dissolved distance between metropole and colony, the Tichborne case amplified space. The conceptual and physical space between metropole and colony, and between British and Australian identities, was amplified by both those who supported the Claimant's cause and those who denigrated it.

Before assessing responses to British stereotypes of Australia connected to the case, and the extent to which the Tichborne case also ignited a pre-political movement in Australia, it is valuable to explore how the story resonated in the Australian newspaper press. Michael Roe suggests that many Wagga Wagga locals expressed an interest in the Tichborne story from its outset, as shown by how the Wagga Wagga Express 'boomed the local boy's story', and excerpts were copied from the Wagga Wagga Express into publications throughout Europe. ${ }^{102}$ The newspaper was initially reluctant to heed the rumour that a 'veritable British heir' was quietly residing in the region, but it soon supported the Claimant by publishing stories recounting his life in Australia. ${ }^{103}$ Although most pronounced in Wagga Wagga, initial fascination with the case spanned across Australia. Many other New South Wales newspapers, including the Empire, the Tumut and Adelong Times, and the Illawarra Mercury, were quick to accept the Claimant as the 'rightful' heir to the Tichborne baronetcy; the Tumut and Adelong Times called him 'our colonial baronet'; and Bell's Life in Sydney and Sporting Chronicle wished him well on his journey back to the 'old country'. ${ }^{104}$ Elsewhere, newspapers across the country labelled the story as 'romantic'. ${ }^{105}$

As some newspapers remarked, New South Wales was no stranger to producing 'claimants' to English titles. In 1835, a transported convict under the fictitious name of 'John

\footnotetext{
${ }^{101}$ R. M. Gurnell, A Critical Review of the Tichborne Trial (London: W. Wilfred Head, 1876), p.14.

102 Michael Roe, Kenealy and the Tichborne Cause: A Study in Mid-Victorian Populism (Melbourne: Melbourne University Press, 1974), p.33.

${ }^{103}$ Quoted in Border Watch, 18 August 1866, p.3

${ }^{104}$ Empire, 8 August 1866, p.5; Tumut and Adelong Times, 9 August 1866, p.2; Illawarra Mercury, 10 August 1866, p.2; Tumut and Adelong Times, 21 January 1867, p.3; Bell's Life in Sydney and Sporting Chronicle, 11 August 1866, p.2.

${ }^{105}$ For example, see Argus, 31 July 1866, p.7; Border Watch, 18 August 1866, p.3; Southern Argus, 2 February 1867, p.4.
} 
Dow' was charged with forgery in Sydney for claiming to be 'Edward, Lord Viscount Lascelles, the eldest son of the Earl of Harewood, and heir apparent to that illustrious name'. ${ }^{106}$ That trial, as Kirsten McKenzie has found, took place at a time when many were 'wracked with doubts' about the definitions of status and the right to social and political power in a land where most colonists had arrived as convicted criminals. ${ }^{107}$ The notion that 'shrugging off one's life and taking up another was part of making out a new society' could also be applied to both the Tichborne case and to Madeleine Smith's case later in the nineteenth century, as BritishAustralians sought to reconcile national identity with prevailing anxieties over ex-convictism, as Chapter Four demonstrates. ${ }^{108}$

Rumours that the Claimant was an imposter began circulating almost immediately as the Tichborne story gained national and international traction, and even before the Claimant's identity as Arthur Orton was called into question. ${ }^{109}$ When the Tichborne family's solicitor, John Mackenzie, found evidence in Gippsland that suggested that the Claimant was identical to Orton in January 1867, expressions of doubt became more pronounced. The Wagga Wagga Express was quick to dismiss the Claimant following Mackenzie's discovery by declining to 'give him the title to which he is now laying claim'. ${ }^{110}$ It also voiced support for its contemporaries, the Empire and the Albury Banner, after the Claimant filed a libel lawsuit against the papers for publishing articles that allegedly attacked him personally and questioned his claims to the baronetcy. ${ }^{111}$ Like the Wagga Wagga Express, the Empire was not always dismissive of the Claimant. After Deniliquin's Pastoral Times published an article that criticised the Claimant's character and appearance, the Empire charged the newspaper with prejudice while also noting that it did not want to express 'any opinion on the merits of this remarkable case'. ${ }^{112}$ Covered by newspapers across Australia, a broadside war ensued, and the Pastoral Times defended the article by stating that the newspaper was itself a supporter of the Claimant and even gave him $£ 600$ in financial assistance, which the Claimant's Sydney solicitors denied. ${ }^{113}$

\footnotetext{
${ }^{106}$ Kirsten McKenzie, A Swindler's Progress: Nobles and Convicts in the Age of Liberty (Sydney: New South Wales Press Ltd, 2009), p.6.

107 Ibid, p.8.

108 Ibid, p. 272.

${ }^{109}$ For examples of rumours of the Claimant being an imposter, see Empire, 14 January 1867, p.8; Brisbane Courier, 23 March 1867, p.6; Hamilton Spectator and Grange District Advertiser, 15 June 1867, p.1.

${ }^{110}$ Quoted in Gippsland Times, 5 March 1868, p.2.

${ }^{111}$ See Empire, 1 May 1867, p.5; 1 January 1868, p.3. The Albury Banner's doubts of the Claimant's identity are quoted in Goulburn Herald and Chronicle, 28 August 1867, p.2; Argus, 10 October 1867, p.2.

112 Empire, 8 August 1867, p.2.

${ }^{113}$ See Empire, 12 August 1867, p.5; Herald (Melbourne), 20 August 1867, p.2.
} 
Despite the Claimant's threat of libel following the Orton scenario, the Empire's stance was more moderate compared to its contemporaries. The Pastoral Times became extremely dismissive of the Claimant and penned a strongly worded article that lambasted his attempt at aristocracy and listed the reasons why he was a fraud. ${ }^{114}$ The Albury Banner wrote cynically that the Claimant will 'lament his aristocratic aspirations for seven long years in one of her Majesty's penitentiaries' if Mackenzie is successful in his endeavours. ${ }^{115}$ Elsewhere, newspapers across Victoria reprinted Pastoral Times articles that labelled the Claimant as a 'man of deception' and variously expressed doubts as to the Claimant's identity and the authenticity of the evidence supporting him. ${ }^{116}$

Although many Australian newspapers doubted the Claimant in the lead-up to his civil trial, several concurred that Henriette Tichborne was a reliable authority and continued to back the Claimant's cause. Such support was not always confined to specific regions. By the time news that he could be Orton came to light, the Pastoral Times suggested that most people in Deniliquin and Wagga Wagga did not support him. ${ }^{117}$ In other New South Wales towns, the Tumut and Adelong Times ardently declared its support for the Claimant, as did the Queanbeyan Age, which criticised the people of Wagga Wagga for not being able to 'swallow' the idea of Castro being a Tichborne. ${ }^{118}$ Larger metropolitan newspapers, such as the Argus and the Sydney Morning Herald — while not always patriotic in their support — were far less dismissive of the Claimant as evidence against him mounted, especially when compared to their respective competitors, the Melbourne Herald and the Empire. In Tasmania, both the Launceston Examiner and the Mercury stood by the Claimant, with the former expressing regret in 1868 for having previously shunned him. ${ }^{119}$ During the civil trial, the Sydney Morning Herald expressed outrage toward the condemnation of the Claimant by the English papers while his criminal case was 'sub judice' and wrote that the New South Wales press, as a rule, abstain from 'all comments on either civil or criminal cases until a decision has been arrived at'. ${ }^{120}$ However, as the civil trial progressed, that rule was not always followed.

Local affidavits for and against the Claimant were also published in newspapers across every region of the country. The Claimant's Wagga Wagga solicitor, William Gibbes, was one

\footnotetext{
${ }^{114}$ Quoted in Toowoomba Chronicle and Queensland Advertiser, 25March 1868, p.4.

${ }^{115}$ Quoted in Goulburn Herald and Chronicle, 28 August 1867, p.2.

${ }^{116}$ For example, see Ballarat Star, 12 June 1867, p.2; Age, 27 February 1868, p.5.

${ }^{117}$ Quoted in Toowoomba Chronicle and Queensland Advertiser, 25 March 1868, p.4.

${ }_{118}$ Tumut and Adelong Times, 10 June 1867, p.2; Queanbeyan Age, 22 July 1869, p.3.

${ }_{119}^{11}$ Launceston Examiner, 16 April 1867, p.4; Mercury (Hobart), 17 March 1868 , p.2.

${ }^{120}$ SMH, 28 June 1872, p.4.
} 
of the first to use the newspaper press as an organ for voicing support for his client against detractors in $1867 .{ }^{121}$ By the end of the year, the Claimant's solicitor in Britain, John Holmes, selected the Melbourne law firm, Sedgefield \& Allport (because of his friendship with S. W. Sedgefield), to act on behalf of the Claimant, and the firm in turn employed Otto Berliner, the proprietor of the Melbourne Private Inquiry Office, to seek evidence on the Claimant's behalf. ${ }^{122}$ Berliner's investigations were regularly chronicled in the press until a highly publicised dispute with the firm over the costs of his inquiries led to his dismissal in April 1868. ${ }^{123}$ Nonetheless, he and other private investigators continued to use their involvement in the Tichborne sensation years later as a source of pride and a unique selling proposition in their advertisements. Cubbit considered himself the 'discoverer of the Claimant to the Tichborne Baronetcy' when advertising his firm during the civil trial, and Wright \& Co. —another private inquiries firmpublished testimonials from Sedgefield and Allport confirming their satisfactory involvement in the 'great' case 'so well known to the public'. ${ }^{24}$

By the time the Claimant's civil trial commenced, coverage of the case had grown exponentially. Like the Smith trial, full day-to-day accounts of both the Tichborne civil and criminal trials-extracted from British papers-occupied entire pages of Australia's metropolitan papers, including the Sydney Morning Herald, the Empire, the Age, the Argus, and the South Australian Register. Although many Australian witnesses gave evidence at the civil trial, new affidavits continued to sprout in the press, particularly after the trial collapsed. The Argus and the Sydney Morning Herald commented on the phenomenon, noting that the excitement surrounding the trial had been reproduced in Australia and was 'as fruitful a topic of conversation' in the colony as it was in London. ${ }^{125}$ Evidence came not only from New South Wales but from as far as Hobart, Geelong, Gippsland, and Ballarat. 'Ballarat seems prolific in items concerning the case', wrote the Age, as colonists continued to come forward with claims to have known either Castro or Orton. ${ }^{126}$

There were marked discrepancies between each new piece of evidence connected to the case that came to light, from a claim by a Sydney hotel landlord that Roger Tichborne stayed

\footnotetext{
${ }^{121}$ See Empire, 30 May 1867, p.5.

${ }^{122}$ Roe, Kenealy and the Tichborne Cause, p.143; Robyn Annear, The Man Who Lost Himself: The

Unbelievable Story of the Tichborne Claimant (Melbourne: The Text Publishing Company, 2002), p.137.

${ }^{123}$ For example, see Argus, 11 May 1868, p.5; 8 November 1869, p.1. The dispute was also jokingly suggested as the cause for the commotion at Henriette Tichborne's funeral in Melbourne Punch, 14 May 1868, p.1.

${ }^{124}$ SMH, 12 July 1871, p.1; Argus, 18 June 1870, p.2; Australasian, 22 July 1871, p.4.

${ }^{125}$ Quoted in Argus, 9 September 1871, p.1. See also SMH, 8 September 1871, p.5.

${ }^{126}$ Age, 8 September 1871, p.3.
} 
with him to a pocket-book from an old acquaintance of the Claimant, Charles Cox, suggesting that the Claimant identified as Tichborne and Castro from 1854. ${ }^{127}$ More wild speculation stemmed from the notion that the Claimant murdered Tichborne in the Australian bush, along with the Claimant's own suggestion in court that he and Orton were involved in a horse-stealing case in Castlemaine in 1859 , which numerous witnesses testified to during the criminal trial. ${ }^{128}$ Warning all who took an interest in the case to 'beware of counterfeits', the Age declared in September 1871 that 'there is nothing but Tichborne paragraphs all over the colony'. ${ }^{129}$ Roe suggests that pursuing the 'intricacies' of these Australian affidavits 'would render little profit' due to their lack of credibility and the contradictions they present. ${ }^{130}$ Nonetheless, their contradictory nature highlights how the Tichborne phenomenon was both far from unanimous in terms of those who supported the Claimant yet ubiquitous in the way it permeated every region of the country.

After the civil trial collapse, Australian newspapers became more assertive in weighing in on the Tichborne case, and the verdict was headline news. The Sydney Morning Herald, which covered both trials in significant detail and largely refrained from criticising the Claimant before his civil trial, began publishing articles that highlighted the flaws in the Claimant's defence. ${ }^{131}$ The Empire dismissed the Claimant for involving Australia in unnecessary scandal and considered the case to be 'unworthy of notice'. ${ }^{132}$ Wagga Wagga's newspapers similarly decried the 'horrid butcher' and lamented how the town had become implicated in the 'detestable conspiracy'. ${ }^{133}$ Elsewhere, most newspapers across the country celebrated the termination of the trial, agreeing that justice had been done but expressing remorse that the trial had grown wearisome. ${ }^{134}$ 'Australian readers 'will be neither surprised nor disappointed to learn

\footnotetext{
${ }^{127}$ Ballarat Star, 25 July 1871, p.4; Mount Alexander Mail, 14 September 1871, p.2.

${ }^{128}$ SMH, 24 October 1873, p.6; Edward Kenealy (ed.), The Trial at Bar of Sir Roger C. D. Tichborne, Bart., in the Court of Queen's Bench at Westminster, before Lord Chief Justice Cockburn, Mr. Justice Mellor, and Mr. Justice Lush, for Perjury: Vol. IV (London: “Englishman” Office, 1877), pp.240, 251; Max Everest-Phillips, 'The 1871 'Tichborne Claimant' medal and the forging of Australia's identity', Journal of the Numismatic Association of Australia, Vol. 24, 2013, p.8

${ }^{129}$ Age, 7 September 1871 , p. 2.

${ }^{130}$ Roe, Kenealy and the Tichborne Cause, p.148.

${ }^{131}$ For example, see $S M H, 10$ April 1872, p.4; 8 May 1872, p.6; 26 January 1874, p.5; 11 May 1874, p.3; 10 August 1874, p.6.

132 Empire, 22 October 1872, p.3.

${ }^{133}$ WWA and Riverine Reporter, 13 April 1872, p.2. See also WWE and Murrumbidgee District Advertiser, 10 April 1872, p.2.

${ }^{134}$ For example, see Age, 8 April 1872, p.2; Argus, 8 April 1872, p.4; Ballarat Star, 8 April 1872, p.2; South Australian Advertiser, 8 April 1872, p.2; Ballarat Courier, 9 April 1872, p.2; OMA, 10 April 1872, p.2; Newcastle Chronicle, 11 April 1872, p.2; Northern Argus, 12 April 1872, p.2;

Adelaide Observer, 13 April 1872, p.12; Australasian, 13 April 1872, p.16; Shoalhaven News, Ulladulla and
} 
that the case of the Claimant has utterly and hopelessly collapsed', the Adelaide Observer declared. ${ }^{135}$ As the Age summed up, 'it is simply disgraceful that a low-minded impostor should have been able to stand his ground for more than a hundred days', thus giving observers the impression that the Claimant had a strong case. ${ }^{136}$ Similarly, the Ballarat Star reported that the verdict took many by surprise, especially those whose attention to the particulars of the trial waned as it progressed. ${ }^{137}$ Not yet willing to conclude that the Claimant was an imposter, the Ovens and Murray Advertiser wrote that 'while there are many persons in these colonies who have from the first consistently maintained that the Claimant is an impostor... there are many others who believe that he is the real man'. ${ }^{138}$ Newspapers that continued to voice support for, or at least withhold their judgement towards, the Claimant included the Queanbeyan Age, Hobart's Mercury, and the Maitland Mercury, which sympathised with the Claimant's supporters and suggested that they deserved pity rather than censure. ${ }^{139}$

More denigration of the Claimant erupted after the criminal trial. Following his conviction, the relatively reticent Argus penned a series of columns that examined how the Claimant managed to deceive so many. 'The imposter' was 'so singularly favoured by circumstances', the paper wrote, 'that with a little more caution and industry he might probably have succeeded in baffling the law'. ${ }^{140}$ The Empire suggested that while the trial had not outlasted public interest in Britain, interest among settlers in Australia had already begun to flag, and thus the paper called the final result 'brilliant' and 'adequate' to all but 'fanatics and fools'. ${ }^{141}$ Indeed, the many Australian newspapers that concurred with the verdict shared a mutual feeling of relief that the trial had finally ended. ${ }^{142}$ The Australasian declared the Claimant's conviction as 'too good news to be true', while the Ballarat Star wrote that the

Southern Coast Districts Advertiser, 13 April 1872, p.2; Armidale Express and New England General Advertiser, 13 April 1872, p.2; Burrangong Argus, 13 April 1872, p.2; Hay Standard and Advertiser for Balranald, Wentworth, Maude, Booligal, Wilcannia, Menindie, Bourke, \&c., 17 April 1872, p.2.

${ }^{135}$ Adelaide Observer, 13 April 1872, p.12

${ }^{136}$ Age, 8 April 1872, p.2.

${ }^{137}$ Ballarat Star, 8 April 1872, p.2.

${ }^{138}$ OMA, 10 April 1872, p.2.

${ }^{139}$ Queanbeyan Age, 26 September 1872, p.2; Mercury (Hobart), 9 April 1872, p.2; Mercury (Hobart), 25 November 1873, p.2; Maitland Mercury and Hunter River General Advertiser, 13 April 1872, p.2.

${ }^{140}$ Argus, 7 March 1874, p.9. See also Argus, 3 March 1874, p.5.

${ }^{141}$ Empire, 3 March 1874, p.2; 1 May 1874, p.2; Age, 2 March 1874, p.2.

${ }^{142}$ Other newspapers that concurred with the verdict included the South Australian Register, 2 March 1874, p.5; Evening Journal (Adelaide), 2 March 1874, p.2; South Australian Advertiser, 2 March 1874, p.5; WWA and Riverine Reporter, 4 March 1874, p.2; Maryborough Chronicle, Wide Bay and Burnett Advertiser, 5 March 1874, p.2; Leader, 7 March 1874, p.17; Border Watch, 7 March 1874, p.2; Maitland Mercury and Hunter River General Advertiser, 10 March 1874, p.2; Australian Town and Country Journal, 23 May 1874, p.28; Adelaide Observer, 23 May 1874, p.18; 
verdict was almost universally endorsed by Britons. ${ }^{143}$ Papers that were earlier reluctant to dismiss the Claimant rescinded their support, including the Gundagai Times ${ }^{144}$ the Riverine Grazier, ${ }^{145}$ the Telegraph, St Kilda, Prahran and South Yarra Guardian; ${ }^{146}$ and the Mercury, which labelled the Claimant 'the cleverest scoundrel, the most ripened slanderer, and the most audacious liar that the Christian era has ever witnessed'. ${ }^{147}$ Sydney's Evening News wrote that the Claimant 'goes to his thoroughly deserved fate without pity of further human interest of any kind - except indeed to some possible future museum of monstrosities as the rarest specimen ever seen of a rascal'. ${ }^{148}$

Some newspapers did not weigh in on the verdict, and a handful were still cagey about dismissing the Claimant as explicitly and passionately as their contemporaries. Although reporting that almost all 'English-speaking' people would be satisfied with the verdict, the Kapunda Herald was still not entirely convinced that the Claimant was Orton. ${ }^{149}$ The Bendigo Advertiser shared similar doubts, although later retracted its remarks. ${ }^{150}$ The Wallaroo Times and Mining Journal was not willing to relinquish its support for the Claimant and contended that he was another 'victim of a deep laid plot and aristocratic prejudice'. ${ }^{151}$

While scholars have variously explored how British interpretations of the Claimant and of Australia played interdependent roles in shaping the other, there is a dearth of historiography that centres on what the Claimant meant to white colonial Australians. Indeed, Australian coverage of the case responded in diverse ways to the stereotypes of Australia advanced by the British press. Some heeded the views of British newspapers that the discovery of a long-lost baronet in a quiet New South Wales town had a peculiar but romantic quality. As the Mount Alexander Mail wrote, the case was charming for Australians 'by reason of the alleged rightful heir having turned up in Australia, after a lengthened secession from polite society, and after 'a cultivation of the useful arts of splitting and bullock punching'. ${ }^{152}$ The Age and Ballarat Courier

\footnotetext{
${ }^{143}$ Quoted in Armidale Express and New England General Advertiser, 14 March 1874, p.3; Ballarat Star, 4 May 1874, p.2.

144 The newspaper asserts that it stopped supporting the Claimant after the civil proceedings. See Gundagai Times and Tumut, Adelong and Murrumbidgee District Advertiser, 7 March 1874, p.2.

${ }^{145}$ Riverine Grazier, 11 March 1874, p.2.

${ }^{146}$ Quoted by the correspondent, 'Figaro', in Telegraph, St Kilda, Prahran and South Yarra Guardian, 7 March 1874, p.2.

147. Mercury (Hobart), 10 March 1874, p.2.

148 Quoted in Empire, 5 March 1874, p.4.

${ }^{149}$ Kapunda Herald and Northern Intelligencer, 3 March 1874, p.2.

${ }^{150}$ Bendigo Advertiser, 2 March 1874, p.2. The newspaper retracted its remarks and referenced The Times in implying that the Claimant was Orton. See Bendigo Advertiser, 3 March 1874, p.2.

${ }^{151}$ Wallaroo Times and Mining Journal, 4 March 1874, p.2.

${ }^{152}$ Mount Alexander Mail, 17 July 1867, p.3.
} 
both noted how the 'retrogression' in appearance, manner, and language 'between the two Rogers' was attributed to 'the demoralising influences of a life in the Australian bush'. ${ }^{153}$ Those that dismissed the Claimant after the criminal trial also advanced the 'bushman' stereotype. Regarding the Claimant as a 'low, vulgar, ignorant boor', the South Australian Advertiser and Express and Telegraph wrote that a life in the Australian bush would 'degrade some natures of a low type to begin with'. ${ }^{154}$ The Argus drew on racial stereotypes and concurred that the idea that the Claimant had 'gradually degenerated to a state of savage ignorance' during his time in Australia was a credible one, noting:

That a man, such as Roger Tichborne was described by the Claimant's Counsel - a sulky and drunken cub, whose intellect was below par, and who had learned English as a foreign language, might acquire some vulgarisms and inaccuracies during a long companionship with blackguards, would certainly seem probable. $^{155}$

An acceptance that Australia had somehow made the Claimant more 'savage' transcended the question of whether he was the genuine heir or not. Robyn Annear suggests that Australian journalists 'were less scandalised by the case than were their British counterparts'. 'It was not because colonial writers and readers were more inclined to believe the Claimant (quite the opposite)', writes Annear, but that 'few among them had difficulty in believing that a gentleman might willingly trade rank and privilege for a life in the bush'. ${ }^{156}$ Such an assertion is contested by the mounting dismissal of the Claimant in the Australian press, particularly following the criminal trial, as illustrated by the Mercury's retrospective statement that it was 'extraordinary' how people believed that a baronet would 'live for years and years a wild life in the Australian bush, suffering privation and hardship, when he might go home and enjoy the most ample luxury' ${ }^{157}$ For other detractors, as the Riverine Herald implied, it was suggested that the Claimant 'would have done much better for himself had he stuck to his butchering trade on the Murrumbidgee'. ${ }^{158}$ While the narrative was no doubt a strange one, the idea that Australia provided a retreat from what Sam Hutchinson calls 'emasculating metropolitan industrialism' could also be seen as endearing, particularly for those in Australia who supported the Claimant's cause in its early phase, which is when Annear is likely referring to. ${ }^{159}$ As the Tumut and

\footnotetext{
${ }^{153}$ Age, 4 July 1871, p.3; Ballarat Courier, 4 July 1871, p.2.

154 South Australian Advertiser, 2 March 1874, p.2; Express and Telegraph, 2 March 1874, p.2.

${ }^{155}$ Argus, 7 March 1874, p.9.

156 Annear, The Man Who Lost Himself, p.376.

${ }^{157}$ Mercury (Hobart), 10 March 1874, p.2; Illawarra Mercury, 20 March 1874, p.2.

${ }^{158}$ Riverine Herald, 16 March 1872, p.2.

${ }^{159}$ Sam Hutchinson, Settlers, War, and Empire in the Press: Unsettling News in Australia and Britain, 18631902 (Cham: Palgrave Macmillan, 2018), p.33.
} 
Adelong Times asserted in expressing its support for the Claimant, 'it was more difficult to credit that an unknown illiterate impostor should come from another hemisphere to advance such a claim than to believe that he is Sir Roger'. ${ }^{160}$

In the same way that the Smith case evoked connections to Scotland, the Tichborne phenomenon also became a source of pride for some Australians, even for those who did not wholeheartedly believe his story. To this end, the increasing dismissal of the Claimant in the press ran counter not only to the many affidavits that supported him but also to some external observers. U.S. artist and traveller, Augustus Baker Peirce recalled that 'the people of Wagga Wagga thoroughly believed in his cause and were indignant at his treatment', and that several townspeople had raised funds to enable him to return to England to claim his inheritance. ${ }^{161}$ Recounting his travels through Australia in 1871, English novelist Anthony Trollope similarly noted that:

Throughout the colonies generally I found that the opinions of men and women ran very much in favour of the Claimant; - not in any way because he was an Australian, for no colonist was fond of him, but apparently there was a pleasurable excitement in the idea that such a man should return home from the wild, reckless life of the Australian bush and turn out to be an English baronet. ${ }^{162}$

Thus, both accounts suggest that support for the Claimant among Australians stemmed less from a belief that he was the true heir and more from a fondness towards the 'romance' of his story and a reluctance to dismiss his cause without giving him the right to a fair (legal) hearing.

According to the Sydney Morning Herald, the popular Tichborne demonstrations that erupted in Britain after the civil non-suit did not carry over to Australia. Although the case was well-known in the colony, 'as well known in Sydney as it is in London', colonists were less emotionally stirred by the case, the paper implied; 'Wagga Wagga was apathetic' and 'Deniliquin made no sign'. ${ }^{163}$ While other newspapers reported on the case as 'the universal subject of debate', the Empire was quick to dismiss the idea that the civil trial had any 'deep interest' among Australians, while ironically reporting on it regularly. ${ }^{164}$ Indeed, such dismissal over whether the Tichborne case warranted excitement in Australia stemmed in part from the reaction to how the case had put the colony on the map in polarising ways.

\footnotetext{
${ }^{160}$ Tumut and Adelong Times, 10 June 1867, p.2.

${ }^{161}$ A. B. Peirce, Knocking About: Being Some Adventures of Augustus Baker Peirce in Australia (New Haven: Yale University Press, 1924), p.153.

162 Anthony Trollope, Australia and New Zealand, Volume I (Leipzig: Bernhard Tauchnitz, 1873), p.82.

${ }^{163} \mathrm{SMH}, 12$ October 1872, p.7.

${ }^{164}$ Empire, 9 August 1871, p.2. See also Argus, 1 August 1871, p.1
} 
Wagga Wagga's entanglement with the case meant that the small town became the centre stage for the Claimant's story from its outset. The town's apparent apathy toward the civil trial, as suggested by the Sydney Morning Herald, masked locals' wide-ranging attitudes toward how Wagga Wagga was being represented in the press. Despite its dismissal of the Claimant's veracity, the Wagga Wagga Advertiser remarked that there was 'nothing more fortunate' to happen to Wagga Wagga than discovering 'a Baronet in the rough' for, by 1871, the town was now a community where 'butchers suddenly blossom into baronets'. ${ }^{165}$ The paper expressed hope that the Claimant would win his civil trial if only for the sake of Wagga Wagga's newfound international reputation. ${ }^{166}$ As the Sydney Mail recalled in 1897, the Claimant made Wagga Wagga a household word in the mouths of 'the greatest celebrities' of the day 'by virtue of having once been in business in the town'. ${ }^{167}$ After the Claimant left Australia, a sketch of the shop was sent by Samuel Hawkins, proprietor of the Wagga Wagga Express, to The Graphic, and the shop became the subject of several pantomimes in London during the civil trial. ${ }^{168}$ Supporters and detractors correlated images of the shop with impressions of modesty. Scottish explorer James Coutts Crawford, formed a 'very poor opinion of Wagga Wagga' based on the sketch but, once arriving there, found the town to be "particularly pretty... well built, with nice gardens, a place of considerable importance and of civilised aspect'. ${ }^{169}$ The shop was soon 'torn to pieces for souvenirs' of the Claimant, the 'Tichborne buildings' were later erected in its place, and the site continued to be advertised as the 'former residence of the alleged Sir Roger' in lists of places to visit in Wagga Wagga. ${ }^{170}$

\footnotetext{
${ }^{165}$ WWA and Riverine Reporter, 12 July 1871, p.2.

166 Ibid.

${ }^{167}$ Sydney Mail and New South Wales Advertiser, 4 September 1897, p.493

${ }_{168}$ Australian Town and Country Journal, 6 July 1872, p.20; SMH, 18 March 1872, p.7.

169 James Coutts Crawford, Recollections of Travel in New Zealand and Australia: A Journey from New Zealand to Tasmania and Australia (London: Trübner and Co., 1880), pp.291-292.

${ }^{170}$ Peirce, Knocking About, p.153. See also Australian Town and Country Journal, 6 July 1872, p.20; Australasian, 7 September 1895, p.28; Advocate, 22 June 1912, p.18; Weekly Times, 20 October 1928, pp.5-6. In 1938, a model of the shop was displayed at Edmondson's Emporium, the later occupier of the site, to celebrate the 150th anniversary of the arrival of the first British fleet to Australia in 1788. See also WWE, 8 October 1938, p.6.
} 
This content is unavailable. Please consult the figure list for further details.

Figure 1: 'The Tichborne Claimant in Wagga Wagga', Illustrated Sydney News, 17 March 1883, p.16.

Evidence as to whether Wagga Wagga locals generally supported the Claimant is conflicting. Upon the conclusion of the civil trial, the Wagga Wagga Express noted that many knew that the Claimant was an imposter all along, evidenced by the extent of the betting against him 'from the very first moment that he put forth his claim'. ${ }^{171}$ The Wagga Wagga Advertiser expressed remorse that many locals supported and financed the Claimant's pilgrimage to Britain, but asserted that the town was not solely to blame for 'letting loose the monster to prey upon English credulity' and that the butcher-baronet narrative was more of an English creation than a Wagga Wagga or even an Australian one. 'Whether Australia is responsible for making a savage of Arthur Orton may very well be doubted', the paper wrote. ${ }^{172}$ The notion that there was a discrepancy between sharp derision of the Claimant in the press and numbered albeit less obvious support among Wagga Wagga locals is echoed by Roe's assertion that criticism directed

${ }^{171}$ WWE and Murrumbidgee District Advertiser, 10 April 1872, p.2.

${ }^{172}$ WWA and Riverine Reporter, 13 April 1872, p.2. 
at the Claimant 'might have represented a minority view'. ${ }^{173}$ Although some Wagga Wagga locals were vocal in their dismissal of the Claimant, 'there are a far larger number who hold that he is what he represents himself', the Illustrated Sydney News declared in $1883 .{ }^{174}$ Indeed, even the previously dismissive Wagga Wagga Express wrote retrospectively in 1883 that it doubted the veracity of those prejudiced against the Claimant at the criminal trial and suggested that the investigation into William Cresswell, a patient at the Parramatta Lunatic Asylum who was rumoured to be the real Arthur Orton (discussed in Chapter Four), had 'every right' to 'weaken the credit' of certain witnesses as well. ${ }^{175}$

Support for the Claimant in Wagga Wagga was often more of a response to, than an outcropping of, the Tichborne movement in Britain. Whereas detractors in Britain used the town's name to make gibes at the 'ludicrousness' of the Claimant's cause, Wagga Wagga locals too could self-referentially joke at how the British public had catapulted the town into newfound celebrity. ${ }^{176}$ Archibald Forbes, a self-proclaimed friend of the Claimant, wrote that he was 'immensely tickled by the amused contempt the good folks of that place entertained for the gullibility of the people who were taken in by the pretensions of Tom Castro, whom Wagga Wagga knows so well and so heartily despised'. ${ }^{177}$ Journalist Nancy Dexter similarly wrote in 1966 that the people of Wagga Wagga had long been proud to call the Claimant an 'adopted son' albeit a 'rogue' whose authenticity could not be validated but whose synonymity with the town could only be accepted. ${ }^{178}$ 'Wagga Wagga will henceforth be familiar to all students of legal history', the Sydney Morning Herald declared in $1874 .{ }^{179}$ It was the 'town to which the Tichborne Claimant gave celebrity', whether inhabitants liked it or not, and the Illustrated Sydney News went so far as to suggest that the Tichborne case had transformed the town from a mere name to a tangible fact. ${ }^{180}$

Like the fascination with Madeleine Smith in Melbourne, Wagga Wagga's amusement with the celebrity of the Claimant carried over to the Australian theatre scene. In 1871, Frank Hutchinson, the editor of the Wagga Wagga Advertiser, penned a burlesque entitled The Butcher-Baronet; or the Wagga Wagga Mystery which satirised the case. The play was

\footnotetext{
${ }^{173}$ Roe, Kenealy and the Tichborne Cause, p.146.

${ }^{174}$ Illustrated Sydney News, 17 March 1883, p.10.

${ }^{175}$ WWA, 7 July 1883, p.2.

176 Annear, The Man Who Lost Himself, p.377.

${ }^{177}$ Evening News (Sydney), 10 December 1884, p.5.

${ }^{178}$ Nancy Dexter, 'Wagga Wagga and the Tichborne Case', Walkabout, Vol. 32, no. 8, 1966, pp.19-21.

179 SMH, 30 March 1874, p.3.

${ }^{180}$ Ibid, 10 June 1878, p.5; Illustrated Sydney News, 17 March 1883, p.10.
} 
especially critical of Mary Ann Bryant (the Claimant's wife and a former laundress) and her aspirations to wealth and title. ${ }^{181}$ When it was staged in 1872, Bryant's character was omitted from the play at the request of her mother; nonetheless, the play was reported to have enjoyed successful runs in Goulburn's Mechanics' Institute and later at a crowded Royal Victoria Theatre in Sydney. ${ }^{182}$ Despite its favourable reception, the play's producers cited its timingcoming out at the end of the civil trial—as reason for its short run, while also expressing surprise that unlike Britain, Australia had hitherto 'no tale, burlesque or play founded upon' the case despite the Claimant's connection to the colony. ${ }^{183}$

Wagga Wagga might have been synonymous with the Claimant's local identity, but the case was also contemporaneous with Australia's embryonic national identity as distinct from Britain. Over the late nineteenth century, the movement toward Australian federation was brewing. Although it was not until the early 1880 s that strident steps to unify its six colonies were taken, questions were being raised in the 1870 s over the future survival of the British Empire and the possibility of an imperial federation. ${ }^{184}$ 'Britishness', as the Smith case showed, was an elusive term, and the Tichborne case further highlighted how British-Australian identities were underscored by 'instability' and 'undecidability' ${ }^{185}$ Australian self-interest, selfdetermination, and opposition to imperial federation juxtaposed with, yet depended on, devotion to empire and pride in the mythology of Britishness. ${ }^{186}$ Before The Bulletin cartoonist Livingston Hopkins represented Australia as the figurative, coming-of-age 'little boy from Manly' following its responses to imperial conflict in Sudan in 1885, the Claimant was also construed as a symbol of Australia's national character. ${ }^{187}$

For example, Australian newspapers regularly commented on how the case gave Australia recognition among observers in Britain. The Age wrote favourably about how many

\footnotetext{
${ }^{181}$ Roe, Kenealy and the Tichborne Cause, p.147.

182 WWA and Riverine Reporter, 15 May 1872, p.2; Goulburn Herald and Chronicle, 11 May 1872, p.4; WWA and Riverine Reporter, 19 June 1872, p.2.

${ }^{183}$ SMH, 17 June 1872, p.5; 12 June 1872, p.10.

${ }^{184}$ For example, see Luke Trainor, British Imperialism and Australian Nationalism: Manipulation, Conflict and Compromise in the Late Nineteenth Century (Cambridge: Cambridge University Press, 1994), pp.8-12; Peter Cain (ed.), Empire and Imperialism: The Debate of the 1870s (South Bend, Indiana: St. Augustine's Press, 1999).

${ }^{185}$ Cassie Dawson, “"The Slaughterman of Wagga Wagga”, Imposture, National Identity, and the Tichborne Affair', Australian Literary Studies, Vol. 21, no. 4, 2004, pp.7, 12.

186 Russell McGregor, 'The necessity of Britishness: ethno-cultural roots of Australian nationalism', Nations and Nationalism, Vol. 12, no. 3, 2006, p.496; Kate Darian-Smith, 'Images of Empire: Gender and Nationhood in Australia at the Time of Federation', in Kate Darian-Smith, Patricia Grimshaw, and Stuart Macintyre (eds.), Britishness Abroad: Transnational Movements and Imperial Cultures (Carlton: Melbourne University Press, 2007), p.157.

${ }^{187}$ Darian-Smith, 'Images of Empire', pp.157-158.
} 
parts of Victoria were becoming household words to the world through reports of the trial. One 'home correspondent' who had never heard of Melbourne prior to the case noted how the Claimant did far more to 'ventilate' and advertise Melbourne and Australia than any emigration scheme or agents-general. 'What a delightful climate you must have', they wrote, 'to make a man to work hard at manual labor [sic] for years and years, when he could have all that money could buy'. ${ }^{188}$ During the civil trial, many newspapers echoed the Sydney Morning Herald's appreciation for how the Australian colonies 'occupied a good deal of attention in English newspapers' due to the Tichborne case. 'Everything written is not wise, but then everything has a power, and in the case of colonies it is better to be misunderstood than ignored'. ${ }^{189}$ The Melbourne Punch correlated how Britons only spoke about Australia because of 'Tichborne and Trollope' with suggestions that England 'is a country great and splendid' but many think 'her mighty role is ended'. ${ }^{190}$ It went on to note, 'our land, the best-gem in her bright regalia... Is looked for on the maps by grave and gay... And all because a man, whom fate makes sport on... stole horses here-party by name of ORTON!' ${ }^{191}$ Indeed, such sentiments reflected local newspapers' frustrations over Australia's colonies receiving scant attention in metropolitan newspapers and being 'isolated from European entanglements' before the completion of the Overland Telegraph Line. ${ }^{192}$ Prior to 1872 , local newspaper agents pushed for a reduction in postal charges because, as politician James Butters argued, Britain's 'ignorance, with regard to the colony, was most remarkable' and the dissemination of 'favorable' [sic] colonial information should have 'precedence over any mere consideration of revenue'. ${ }^{193}$ That a case as absurd as the Claimant's continued to be given preferential treatment in the British press over other colonial matters reinforced both the saleability of the Tichborne story in Britain and-as the Sydney Morning Herald wrote_- 'the gullibility of the British public'. ${ }^{194}$

Roe notes that after the civil trial, the case soon became 'if not Australian folk-lore, at least material for local-colour story'. ${ }^{195}$ Newspapers, including those that disputed his claims to the baronetcy or abstained from admiration, heralded the attention that the Claimant's story gave to Australia and found amusement in how Britons subscribed to the narrative so enthusiastically. But Australians also subscribed to the fascination surrounding the case as exemplified by the

\footnotetext{
${ }^{188}$ Age, 27 September 1871, p.2.

${ }^{189} \mathrm{SMH}, 22$ January 1872, p.2.

${ }^{190}$ Melbourne Punch, 5 October 1871, p.4.

${ }^{191}$ Ibid.

${ }^{192}$ Morrison, Engines of Influence, p.208.

193 'Newspaper Postage', VPD, Vol. 9, 1869, p.2280.

${ }^{194}$ SMH, 30 March 1874, p.3.

${ }^{195}$ Roe, Kenealy and the Tichborne Cause, p.147.
} 
multitude of trial reports, figurines, portraits, daguerreotypes, waxwork replicas, songs, and other cultural material transplanted from Britain. An 1874 painting of the criminal trial by Nathan Hughes was a key feature at William Bridges's Haydon Gallery in Melbourne from 1880 (see Figure 2), and photographs of the painting were sold for 1s each amidst renewed interest in the case sparked by the William Cresswell affair during the $1880 \mathrm{~s}$. ${ }^{196}$ The painting was eventually sold at auction for $£ 25$ in 1889 and given to the Wagga Wagga Council Chambers in 1953; a print of the only known photograph to be taken at the trial was donated to the council four years later. ${ }^{197}$

This content is unavailable. Please consult the figure list for further details.

Figure 2: Photograph of Tichbourne [sic] Trial oil painting by Nathan Hughes of London, 1883, Ref. No. H96.160/285, State Library of Victoria (accessed on State Library of Victoria website, http://handle.slv.vic.gov.au/10381/53218, 6 April 2021).

${ }^{196}$ Lorgnette, 18 December 1880, p.2; Geelong Advertiser, 21 June 1883, p.2; Argus, 20 July 1889, p.

${ }^{197}$ Dexter, 'Wagga Wagga and the Tichborne Case', pp.19-21. 
Just as rumours of Smith's whereabouts filled newspapers, the media continued to publish accounts of the Claimant's time in prison following his sentence and give heed to numerous local affidavits, including that of William Cresswell (as Chapter Four discusses), that added more conjecture to the case. Fascination in the colourful nature of case amounted to sharp local and sometimes obsessive efforts to bring about 'Tichborne mania' in the colony, as the Sydney Morning Herald called it, that went beyond the Cresswell affair. ${ }^{198}$ New Zealand was also caught up in the case when a copycat Claimant from Invercargill came forward as Roger Tichborne in 1867 (but was quickly found out to be Thomas Whelan). ${ }^{199}$ Whelan's story featured alongside news of Madeleine Smith's continued offers of marriage and the news that Maria Ellen Kinder, whose former husband Henry was said to have been murdered by her lover, had married in Greymouth. The 'queer' stories, as the Brisbane Courier wrote, were disseminated across Australia. ${ }^{200}$

Gippsland, Victoria, became entangled in the Tichborne case when some locals came forward asserting that there was an Arthur Orton living there in 1856. After viewing a waxwork of the Tichborne Claimant at the Bourke Street waxworks in Melbourne in 1874, J. C. Le Sage penned a letter to the Age claiming that he knew both Orton and Castro in Gippsland and suggested that the figure is not Orton but Castro. ${ }^{201}$ Le Sage and his backers were vocal and publicly jostled with the National Tichborne Release Association through the Gippsland Times on where the real Orton might be. The National Tichborne Release Association was created in Britain in late 1875 as an attempt, parallel to the Magna Charta Association, to release the Claimant from prison. ${ }^{202}$ Le Sage and supporter Robert Shanklin held a series of lectures at Gippsland in 1875 positing that Orton and Castro were distinct individuals, but attendance dropped significantly as, mirroring Kenealy's movement in Britain, the content digressed too waywardly from the Tichborne case. ${ }^{203}$ Le Sage enraged detractors. The Gippsland Times deemed his movement to be 'artless, selfish, and deceitful' and triumphantly declared 'Le Sage baulked' when he eventually conceded that the Claimant was indeed Orton in $1877 .{ }^{204}$

\footnotetext{
${ }^{198}$ SMH, 12 December 1883, p.11.

${ }^{199}$ Evening Post, 4 July 1867, p.2.

${ }^{200}$ Brisbane Courier, 6 July 1867, p.6. See also Age, 8 July 1867, p.5; Mount Alexander Mail, 9 July 1867, p.2;

Queenslander, 13 July 1867, p.2; Leader (Melbourne), 13 July 1867, p.5.

201 Gippsland Times, 21 September 1874, p.3.

${ }^{202}$ Rohan McWilliam, The Tichborne Claimant: A Victorian Sensation (London: Hambledon Continuum, 2007), p.158.

${ }^{203}$ Gippsland Times, 19 June 1875, p.3; 22 June 1875, p.2.

${ }^{204}$ Ibid, 17 January 1877, p.3.
} 
John Dettmer Dodds Jackson was another notable figure whose interest in the Tichborne case received concentrated local attention. Jackson claimed to have met Tichborne and Orton in Launceston in 1855 and asserted that the licensee of the Royal Oak public house, Mary Ann Hedger, was Orton's sister. ${ }^{205}$ He first put forward his theory to the Sydney Morning Herald in 1874, which proprietor John Fairfax found to be marketable to local readers at a time when many were already interested in the criminal trial. ${ }^{206}$ Jackson continued to write letters to Home Secretaries, heads of police, and to the Sydney Morning Herald; he gave evidence at the Royal Commission into the release of Cresswell, and stood by his beliefs until his death in $1901 .{ }^{207}$ In 1885, he published a pamphlet entitled Sir Roger Tichborne Revealed!, which made his name synonymous with the case thereafter. The pamphlet was sold throughout the country and was particularly popular in Sydney and Tasmania, but reception was mixed. ${ }^{208}$

A more vigilant champion of the Tichborne cause was Alfred Stephen, Chief Justice of New South Wales from 1845 to 1873 . Stephen was alluded to in Trollope's writing as the reputable Australian judge found to be 'strongly in favour of the butcher' ${ }^{209}$ Following the criminal trial verdict, he issued an apology through the Sydney Morning Herald for subscribing to the 'delusion in this colony' that Orton and Castro were the same person and outlined reasons why the Claimant was an imposter. ${ }^{210}$ He also justified many others' persistent doubts that the Claimant was Orton by suggesting that the story was infatuating and the prospect of financial reward was too alluring to pass up. ${ }^{211}$ Some newspapers did not take kindly to Stephen's admission. The Wagga Wagga Advertiser called it a mere repetition of what was already known about the 'now sickening case'. ${ }^{212}$ Like many, the Leader in Melbourne saw Stephen's statement as unnecessary, noting that it, if nothing else, only further demonstrated that the Claimant 'whether he be Tichborne, Orton, or Castro, was a vulgar, ill-bred, illiterate man'. ${ }^{213}$ For

\footnotetext{
${ }^{205}$ Roe, Kenealy and the Tichborne Cause, pp.147-148. Orton's sister was revealed to be Mary Ann Tredgett. 206 John Dettmer Dodds Jackson, Sir Roger Tichborne Revealed!: The Discovery of Sir Roger Charles Doughty Tichborne alias Edward Caleb Souper, secretary to Lady Ogle of Withdeane Court near Brighton, Sussex, England, and his confederates (Sydney: H. Garforth, Printer, 1885), p.4.

${ }^{207}$ Evening News (Sydney), 7 February 1900, p.3; Examiner (Launceston), 24 April 1901, p.5.

${ }^{208}$ The Hobart Mercury and the Melbourne Leader noted that it would spark curiosity but was inconclusive; the Inquirer and Commercial News in Perth called it 'ingenious' and suggested that it might finally solve the Tichborne mystery; and the Wagga Wagga Advertiser found the pamphlet to be fatiguing, mystifying, and beneficial only to its printer 'if he charged a fair price for it'. For example, see Leader (Melbourne), 25 July 1885, p.35; Mercury (Hobart), 26 June 1885, p.2; Inquirer and Commercial News, 26 August 1885, p.5; WWA, 9 July 1885, p.3.

209 Trollope, Australia and New Zealand, p.82. See also Roe, Kenealy and the Tichborne Cause, p.147.

${ }^{210}$ SMH, 28 August 1874, p.3

${ }^{211}$ Ibid.

${ }^{212}$ WWA and Riverine Reporter, 2 September 1874, p.2.

${ }^{213}$ Leader (Melbourne), 5 September 1874, p.16.
} 
Guildford Onslow, Stephen's public withdrawal of support was a catastrophic blow to the Tichborne cause in Australia. Writing for the Englishman, Onslow challenged him to rebuke his statements, asserting 'you, a lawyer, a Chief Justice, ask yourself, how can these things be'.214 Stephen did not respond.

Both the Madeleine Smith and Tichborne trials raised questions about colonial identity in subtle and overt ways. The dissemination of news from metropole to colony allowed newspaper readers in Australia to participate in the hearsay and debates that surrounded the trials in Britain. Colonial newspapers regularly fed into the mystery that enveloped the figures at the centre of the cases. The distinctively Scottish nature of the Smith trial was not often commented on but was regularly expressed subtly by way of colonial newspapers relying on Scottish media outlets for updates on the trial's progress. Newspaper reports, wax museums, reported sightings of her in Australia and New Zealand, and stories about how the case evoked subjective memories of Glasgow brought attention to the distinctiveness of Scots law and the possibility of reworking it within a colonial context.

In contrast, the Tichborne case evoked feelings of local pride that emphasised the distinctiveness of local Australian identities. Newspapers covering the Tichborne case were far from unified in their attitudes toward the case, but some found favour in the way the case catapulted Wagga Wagga and Australia to fame. Newspapers responded variously to the stereotypes about Australia advanced by the British press, and often made fun of the British public's fixation with the case in a similar way to how coverage of the Smith trial expressed concern about a purported fascination with crime in Britain, as Chapters Three and Four discuss. Nonetheless, reported sightings of Smith and wide-ranging local affidavits related to the Tichborne case show that colonial newspapers were not immune to scandal and gossip. As Chapters Three and Four find, colonial newspapers regularly emulated the Victorian British public's appetite for sensation as the cases contributed to intersectional debates about gender and class that went hand-in-hand with the ways they figured into debates about local and national identity

\footnotetext{
${ }^{214}$ Quoted in Argus, 11 January 1875, p.9.
} 


\section{Chapter Three: Gender}

Madeleine Smith and the Tichborne Claimant were both heavily scrutinised in the press for the way they appeared in court. Significant public attention was given to how their behaviour echoed or deviated from cultural definitions of femininity and masculinity in Victorian Britain. As Angela Woollacott points out, both femininity and masculinity are directly linked to representations and practices of sexuality, and were associated with the hierarchies of difference, including 'race' and 'class', that were central to both colonial rule and metropolitan culture. ${ }^{1}$ Ideas about gender have featured prominently in histories of the Smith case, but these histories have seldom examined how those ideas featured in a context outside of Britain. Ideas about gender in the context of the Tichborne case have often been side-lined or excluded altogether in favour of class-centric discussions. This chapter focuses on how gender, inextricably linked to the concepts of identity and class, informed coverage of the two cases. It assesses how support for both Smith and Tichborne was largely male in composition, how fascination with the manner and appearance of Smith and the Claimant pervaded newspaper coverage in both Britain and Australia, and how the cases led to sharp debate surrounding femininity and criminality, and stereotypes associated with masculinity in a white settler colonial context.

\section{Madeleine Smith}

Many British and Australian reports of the Madeleine Smith trial labelled Smith as a 'heroine' who, like the martyr label used to describe the murder-accused domestic servant, Eliza Fenning, had garnered a celebrity status through her association with deviance. Criminologists and historians of crime have variously explored the perverted pleasures derived from holding up criminals as celebrities. Lizzie Seal discusses how 'respectability' for women has historically been associated with racial, classist, and gendered assumptions of white, middle-class, and heterosexual womanhood. She notes that 'respectable women who kill' were often portrayed as embodying the traits of appropriate femininity whose deviant actions were not perceived in terms of social expectations but rather explained, for example, through suggestions of mental or

\footnotetext{
${ }^{1}$ Angela Woollacott, Gender and Empire (Basingstoke: Palgrave Macmillan, 2006), pp.2-3.
} 
physical health problems, 'hysteria', or 'madness'. ${ }^{2}$ Judith Knelman points out that the Victorian 'murderess' stood out because they challenged the social stereotypes that correlated femininity with gentleness, submissiveness, passivity, self-sacrifice, and delicacy. ${ }^{3}$ Smith's heroine label can thus be seen as the result of her escaping the gallows (to significant public approval), but also the result of public fascination, and even voyeuristic concern, with her feminine appearance, manner, and composure yet ambiguous and potentially destructive inward persona that needed guidance and saving. Her numerous offers of marriage from young, middle-class men, as newspapers across Australia reported, are illustrative of Gordon and Nair's suggestion that sympathy for Smith grew in part from a 'chivalrous concern for the plight of a young woman' who had fallen from grace and needed her faith restored in someone with more 'honourable' masculinity than L'Angelier. ${ }^{4}$

Fixation on Madeleine Smith's appearance stemmed from the many reports that described her manner in vivid detail. Commentators were not only fascinated by her courtroom demeanour, but also by her short, slight stature, 'deep set' eyes, fair complexion, and prominent features, the 'rich profusion' of her hair, and her 'well-cultivated taste' in clothing. ${ }^{5}$ As the Annual Register noted, 'the simple elegance of her dress and appointments, and her undisturbed manner, appear to have attracted much admiration'. ${ }^{6}$ One of the most detailed depictions of Smith came from an article in the Ayrshire Express, reprinted across Australia, which was at pains to describe all of Smith's physical features. ${ }^{7}$ However, for many readers, words were not enough. The scores of advertisements for full reports of the trial, with portraits of Smith and the letters she wrote to L'Angelier, show that the trial and indeed Smith's appearance could be marketed to those keen to see what she looked like in the flesh.

\footnotetext{
${ }^{2}$ Lizzie Seal, Women, Murder and Femininity: Gender Representations of Women Who Kill (Basingstoke: Palgrave Macmillan, 2010), p.63.

${ }^{3}$ Judith Knelman, Twisting the Wind: The Murderess and the English Press (Toronto, Buffalo, and London: University of Toronto Press, 1998), p.20.

${ }^{4}$ Eleanor Gordon and Gwyneth Nair, Murder and Morality in Victorian Britain: The Story of Madeleine Smith (Manchester: Manchester University Press, 2010), pp.144. For example, see SMH, 8 September 1857, p.2; Illawarra Mercury, 30 November 1857, p.1.

${ }^{5}$ Goulburn Herald and County of Argyle Advertiser, 19 September 1857, p.3; The Times, 2 July 1857, p.5.

${ }^{6}$ The Annual Register, or a View of the History, Politics, and Literature, for the Year 1857 (London: F. \& J. Rivington, 1857), p.530.

${ }^{7}$ Argus, 4 September 1857, p.6; SMH, 8 September 1857, p.3 Star (Ballarat), 9 September 1857, p.3; Northern Times, 12 September 1857, p.4; Tasmanian Daily News, 12 September 1857, p.3; South Australian Register, 14 September 1857, p.3; Hobart Town Mercury, 18 September 1857, p.3; Goulburn Herald and County of Argyle Advertiser, 19 September 1857, 3; Adelaide Observer, 19 September 1857, p.2.
} 
As Dani Cavallaro and Alexandra Warwick point out, 'bodies are always historically situated, and hence sites of ideological contestation'. ${ }^{8}$ Preoccupation with Smith's appearance highlighted how the media could operate in conjunction with more physical forms of punishment, such as public executions, to-following Michel Foucault's words-'deprive an individual of a liberty that is regarded as a right and as property'. ${ }^{9}$ Whereas Foucault suggests that 'physical' forms of punishment have a direct effect on the body, the 'trial by media' punishment that Smith received could also expose the body in a way that invited the public to shame, critique, or admire, as Chapter Two's discussion of waxwork exhibitions demonstrated.

The fascination aroused by Smith's image was both far-reaching and long-lasting, with portraits of Smith sold at booksellers in Melbourne and Sydney and advertised in smaller towns like Bendigo and Wollongong. ${ }^{10}$ A daguerreotype of Smith was also produced by Melbourne engraver, Samuel Calvert, which was used for a portrait on the cover of a controversial pamphlet by Australian writer, Caroline Harper Dexter (see Figure 3), which is discussed below. ${ }^{11}$ Smith's portrait resonated at other outposts of the empire. Dr. Alexander Christison, the son of Edinburgh toxicologist Robert Christison who gave evidence for the prosecution in the Smith case, decorated his dwellings in Fort Agra with Smith's portrait during the 1857 Indian uprisings. ${ }^{12}$ Author Henry James was a boy of 14 at the time of Smith's trial, and was not alone in remembering that Smith was 'almost of the pre-photographic age' and that he would 'give so much for a veracious portrait of her then face'. ${ }^{13}$

\footnotetext{
${ }^{8}$ Dani Cavallaro and Alexandra Warwick, Fashioning the Frame: Boundaries, Dress and the Body (Oxford and New York: Berg, 1998), p.6.

${ }^{9}$ Michel Foucault, Discipline and Punish: The Birth of the Prison, trans. Alan Sheridan (London: Penguin Books, 1977. First published in 1975), p.11.

${ }^{10}$ For example, see Empire, 19 September 1857, p.5; Argus, 10 October 1857, p.6; Illawarra Mercury, 26 October 1857, p.1; Bendigo Advertiser, 8 September 1857, p.3.

11 'Budgery', Miss Madeline Smith: The Glasgow Poisoning Case. A Tale of "Scotch Mist"-ery, Entitled Emile and Madeline; or Love and Murder (Melbourne: Melbourne Herald Office, 1857); Mimi Colligan, 'Waxworks shows and some of their proprietors in Australia, 1850s-1910s', Australasian Drama Studies, No. 34, April 1999, p.89.

12 R. M. Coopland, A Lady's Escape from Gawlior, and Life in the Fort of Agra during the Mutinies of 1857 (London: Smith, Elder, and Co., 1859), p.210. See also Jesse (ed.), Trial of Madeleine Smith, p.85.

${ }^{13}$ Michael Diamond, Victorian Sensation: Or, the Spectacular, the Shocking and the Scandalous in NineteenthCentury Britain (London: Anthem Press, 2003), p.176. See also Richard D. Altick, Victorian Studies in Scarlet (London: J. M. Dent \& Sons Ltd., 1972), p.189.
} 
This content is unavailable. Please consult the figure list for further details.

Figure 3: 'Faithful Portrait, from Daguerreotype, of Miss Madeline Smith', from Caroline Harper Dexter, Miss Madeline Smith: The Glasgow Poisoning Case. A Tale of "Scotch Mist"-ery, Entitled Emile and Madeline; or Love and Murder (Melbourne: Melbourne Herald Office, 1857), p.2. 
While colonial newspapers were generally reluctant to comment on Smith's guilt in the immediate aftermath of her trial, they did not hesitate to comment on her immorality. Like British papers, much of the criticism directed toward Smith in Australia and New Zealand was couched in gendered rhetoric. Australian feminist writer Caroline Harper Dexter was one of Smith's fiercest critics. Already known for lecturing about the benefits of bloomers in Britain, Dexter arrived in Australia from England in 1855 to settle with her husband, William, in Sydney, where she continued to be a key figure in the country's rational dress movement. The couple moved to Gippsland in 1856, where she began writing Ladies Almanack: The Southern Cross or Australian Album and New Years Gift, but they soon separated, and Dexter moved to Melbourne in August 1857. ${ }^{14}$ Writing under the pseudonym, 'Budgery', Dexter published a pamphlet with The Herald entitled Emile and Madeline; or Love and Murder amidst news of the Smith trial's outcome in October $1857 .{ }^{15}$ The pamphlet contained a highly sought-after daguerreotype, as mentioned, along with previously unpublished letters by Smith and Dexter's own commentary of the case.

Dexter was not sympathetic to Smith and — in contrast to Smith's admirers — emphasised the unattractive aspects of her appearance to incriminate her. ${ }^{16}$ She lamented how Smith 'had a wicked heart that repudiated all moral or religious training', criticised her features as 'larger than is pleasant for a woman', and likened her 'unnatural, unwomanly' conduct in her letters to a demon and the biblical figure of Cain. ${ }^{17}$ The article was well-advertised across Melbourne's newspaper press, and the Age called it 'one of the most interesting and thrilling publications of the day'. ${ }^{18}$ However, it appears that the pamphlet did not sit well with Smith's supporters. The Bendigo Advertiser wrote that it was 'evidently the production of a lady, who, if she had been on the jury, would certainly not have returned a verdict of "not proven", but the pamphlet would sell well because it contained a 'well-executed portrait' of Smith. ${ }^{19}$ The Bendigo Advertiser was not the only newspaper to suggest that support for Smith was influenced by gender. The Sydney

\footnotetext{
${ }^{14}$ J. S. Ryan, 'Dexter, Caroline (1819-1884)', Australian Dictionary of Biography, National Centre of Biography, Australian National University, http://adb.anu.edu.au/biography/dexter-caroline-3407/text5173, published first in hardcopy 1972, accessed 21 December 2020.

${ }_{15}$ Patrick Morgan, Folie a Deux: William and Caroline Dexter in Colonial Australia (Quakers Hill: Quakers Hill Press, 1999), pp.84-90.

16 Tiffany Donnelly, “Trumpery Stuff': Gender Politics in Australian Publishing, 1858', Bibliographical Society of Australia and New Zealand Bulletin, Vol. 26, no. 1, 2002, pp.31-32.

17 'Budgery', Miss Madeline Smith, pp.7-11; Morgan, Folie a Deux, p.92.

${ }^{18}$ Age, 22 October 1857, p.5. See also Argus, 10 October 1857, p.6.

${ }^{19}$ Bendigo Advertiser, 2 October 1857, p.2.
} 
Morning Herald reported that 'there are a thousand surmises and various different opinionsthe women generally taking part against her and the men being in her favour' ${ }^{20}$

New Zealand writer and women's rights activist, Ellen Elizabeth Ellis, was another colonial figure who took an interest in the Smith case. Ellis emigrated to Auckland from England with her husband, Oliver, in July 1859. She became involved in the temperance movement and in welfare work for the wives and children of drunkards. In 1882, she penned an autobiographical novel titled Everything is Possible to Will, which told the story of a spirited and intelligent young woman who is limited by the poor education offered to women at the time, marries a man who turns out to be an alcoholic, and travels with him to New Zealand. ${ }^{21}$ Despite being marketed in the New Zealand Herald as a temperance novel, it also-as Kirstine Moffat has noted - served as a 'plea for female education, a demand for economic independence and legal protection for women, an insistence that women take control over their own bodies, practice birth control and ban the corset, and a claim that separation is an option if a marriage proves to be unhappy'.22 The book reveals that the Smith trial had a direct bearing on Ellis's life. The death of their infant son in July 1857 drove her into a 'poison delirium' in which she became 'possessed by the desire' to poison either herself ('Zee' in the novel) or Oliver ('Wrax' in the novel) in the same vein as Smith was alleged to have poisoned L'Angelier. ${ }^{23}$ The novel was published in London, and copies of it were alleged to have been presented to Queen Victoria, former British Prime Minister William Gladstone, and former New Zealand Premier George Grey. However, Ellis's son, John William, the future mayor of Hamilton, in New Zealand's North Island, was not pleased with the characterisation of his father and burned as many copies as possible, thus limiting its readership. ${ }^{24}$

In Sydney's Empire, there was some concern that young colonial women might imitate the follies and vices of those in the 'mother' country like Smith, provoking an urge to reform the 'evils' of modern female education. ${ }^{25}$ Siding with the Inverness Advertiser, one contributor noted how young women were 'taught only the genteel arts of dancing and music and other

\footnotetext{
${ }^{20} \mathrm{SMH}, 8$ September 1857, p.2.

${ }^{21}$ Aorewa McLeod, 'Ellen Ellis, 1829-1895', in Charlotte Macdonald, Merimeri Penfold, and Bridget Williams (eds.), The Book of New Zealand Women / Ko Kui Ma Te Kaupapa (Wellington: Bridget Williams Books, 1991), pp.208-210.

22 Kirstine Moffat, 'The Demon Drink: Prohibition Novels 1882-1924', Journal of New Zealand Literature, Vol. 23, no. 1, 2005, p.156.

${ }^{23}$ Ellen E. Ellis, Everything is Possible to Will [annotated by Rosalie Elliffe] (London: 63 Fleet Street, 1882), pp.87-88, retrieved from http://nzetc.victoria.ac.nz/tm/scholarly/tei-RosEver.html.

${ }^{24}$ McLeod, 'Ellen Ellis', p.208; New Zealand Herald, 22 March 1883, p.5.

${ }^{25}$ Empire, 21 December 1857, p.3.
} 
superficial qualifications', 'frittering away their precious time in reading novels and romances' and 'converting their husbands' homes into scenes of discord and recrimination' ${ }^{26}$ Whereas the Spectator levelled blame at parents' lack of involvement in their children's lives, the blame here was directed at Smith's family's strict adherence to genteel customs and dismissal of L'Angelier on the basis of his lower social position as the cause for her corruption. As the Bathurst Free Press and Mining Journal echoed, it was precisely because Smith was raised by a 'respectable' father, 'kept in' by her parents very tightly, and knew evil only through her Bible and Catechism that she could so easily be swayed by L'Angelier's corrupting influence once removed from the 'nursery' and subjected to the real world. ${ }^{27}$

The argument that Smith's corruption was partly caused by her overprotective father also made its way across the Tasman. One letter to the editor of the Nelson Examiner and New Zealand Chronicle suggested that parents ought to restrain their daughters from dangerous company and reading novels like those Smith had, and lambasted the newly established Colonist newspaper for inferring otherwise. ${ }^{28}$ Another father wrote to the Colonist and asked that parents engage with their children's interests, participate in their pleasures, sympathise in their misfortunes, speak gently of their failings, and rule the home by love rather than (as James Smith had done) by fear. Just because Smith had an expensive education did not mean she had a sound one, the father declared. ${ }^{29}$ It was with contempt toward Smith's family that newspapers like the Argus noted that the poor and working classes in Britain only cheered for Smith because they had bet on the trial's outcome. ${ }^{30}$

Colonial debate about Smith's social and sexual transgression corresponded with debates in Britain about women's proclivities to transgress markers of identity ascribed to them by their parents. Smith was at odds in attempting to relinquish her name as Madeleine Smith and as the spouse of William Minnoch. Addressing L'Angelier as her 'dearest' husband, she also referred to herself as Minie (or Mimi) L'Angelier in her letters to Emilie. ${ }^{31}$ Sara Murphy suggests that 'appearances and civil identity', such as Smith's name, were insufficient or

\footnotetext{
26 Ibid.

${ }^{27}$ Bathurst Free Press and Mining Journal, 28 October 1857, p.4.

${ }^{28}$ Nelson Examiner and New Zealand Chronicle, 11 November 1857, p.3.

${ }^{29}$ Colonist, 17 November 1857, p.2.

${ }^{30}$ Argus, 7 October 1857, p.6.

${ }^{31}$ Brian Jenkins, Madeleine Smith on Trial: A Glasgow Murder and the Young Woman Too Respectable to Convict (North Carolina: McFarland \& Company, Inc., 2019), p.18. See also The Story of Minie L'Angelier or Madeleine Hamilton Smith (Edinburgh: Myles Macphail; Glasgow: T. Murray \& Son; London: Simpkin, Marshall \& Co., 1857).
} 
inconclusive markers' of Smith's identity, despite the press's fervent interest in them. ${ }^{32}$ However, Smith's attempts to retreat from her identity both before and after the trial were not successful, as the evangelical Edinburgh Witness remarked. 'The mellifluous named Madeline [sic] came to be almost thrown back again to that from which it came - the name of Magdalene. Sweet innocent little Mimi of the nursery was no more. ${ }^{33}$

Australian newspapers correlated Smith's apparent loss of innocence by way of her affair with L'Angelier with debate surrounding the Longworth $v$ Yelverton marriage case, where in 1857 Theresa Longworth, an English Catholic, became the wife of William Charles Yelverton, a Protestant member of the Anglo-Irish ascendancy, through a Scottish 'irregular' marriage (by exchanging marital vows). ${ }^{34}$ When Yelverton later became engaged to another woman, both the Irish Court of Common Pleas and Scottish Court of Session declared his marriage to Longworth valid in 1861 and 1862, respectively, but when he appealed his case in 1864, England's House of Lords declared otherwise. ${ }^{35}$ The case closely resonated with Smith's: both Longworth and L'Angelier could claim irregular marriage under the Scottish system, both cases dealt with the topic of bigamy and became causes célèbres throughout Britain, and both ignited correlations between Longworth's and Smith's apparent criminality in the Australian press.

Like Smith, Longworth drew polarised responses in Britain. Many Irish nationalists celebrated her legal victory as a triumph of the Catholic Church over English patriarchy and adopted her as a kind of 'honorary' Irishwoman. ${ }^{36}$ In Scotland, reception was relatively less enthusiastic given that Longworth's case was initially declined but - after later ruling in her favour - the case was used to defend the informalities of the Scottish legal system. ${ }^{37}$ The English press was most vehement in its criticisms, and used the Smith and Yelverton cases to decry the 'shame' of how Scots law 'threatened the morality of the whole empire', as the British Quarterly Review asserted. ${ }^{38}$

\footnotetext{
${ }^{32}$ Sara Murphy, 'Inadmissible Evidence: The Trials of Madeleine Smith and Collins's The Law and the Lady', Victorian Literature and Culture, Vol. 44, no. 1, 2016, p.168.

${ }^{33}$ Bathurst Free Press and Mining Journal, 28 October 1857, p.4.

${ }^{34}$ Ian Ward, Sex, Crime and Literature in Victorian England (London: Hart Publishing Ltd., 2014), p.69.

${ }^{35}$ Douglas B. MacEachen, 'Wilkie Collins and British Law', Nineteenth-Century Fiction, Vol. 5, no.2, 1950, pp.131-132.

${ }^{36}$ Rebecca Gill, 'The Imperial Anxieties of a Nineteenth-Century Bigamy Case', History Workshop Journal, Vol. 57, 2004, pp.69-70; Arvel B. Erickson and Fr. John R. McCarthy, 'The Yelverton Case: Civil Legislation and Marriage', Victorian Studies, Vol. 14, no. 3, March 1971, p.281.

${ }^{37}$ Gill, 'Imperial Anxieties', p.66; Ward, Sex, Crime and Literature in Victorian England, pp.71-72.

${ }^{38}$ British Quarterly Review, Vol. 34, 1861, p.140. See also The Saturday Review of Politics, Literature, Science and Art: Vol. XVIII (London: Saturday Review Office, 1864), 30 July 1864, pp.134-135; The Times, 22 December 1862, p.8.
} 
Newspapers across Australia used comparisons between Smith and Longworth to question the public's fascination with criminal trials involving women. Some newspapers weighed in on the debate about Scottish marriage laws. The Age suggested that it was 'high time that the decision on such a subject of any competent court, in any of the three kingdoms, be binding throughout the Empire'. ${ }^{39}$ The Sydney Morning Herald was the loudest in its dismissal of Longworth, Smith, and the Scottish system, writing that the Scottish marriage law was a 'disgrace to that country' and 'ruinous to Scottish morality'. The paper likened the crowds who cheered Longworth to those who cheered Smith 'when, poor thing, under tremendous temptation, she poisoned, as seemed almost certain, the unhappy and poor spirited L'Angelier'. 40

Other newspapers were more scandalised by the gender component of the two cases. The Goulburn Herald wrote that 'the passionate indulgence of warm imaginings, and the study of poisonous French sentiment, may lead a good woman to become a Therese [Longworth], or a bad one to become a Lola Montes, a Madeline Smith, a Lucretia Borgia [sic]'. ${ }^{41}$ The Herald similarly noted how the Yelverton and Smith cases, and other criminal trials 'of a romantic cast in which the principal character is a lady', were of more interest to the reading population than other European news items. ${ }^{42}$ In its 1864 condemnation of Henrietta Molesworth - the adulterous wife of Supreme Court of Victoria judge Robert Molesworth - the South Australian Register wrote that it was Smith and Yelverton who had set the precedent for such 'bad, shameless' women. ${ }^{43}$ Indeed, newspapers throughout the empire regularly castigated Britons for their glorification of sensational crimes while paradoxically playing a role in its dissemination. As one of the most widely read 'serious' and 'respectable' daily newspapers in Britain, The Times was known for criticising 'sensation verdicts' and 'sensation judgements' based on 'popular frenzy', but it too, as Lauren Harmsen Kiehna writes, had to exercise care in crafting news coverage that allowed its readers to "vicariously enjoy scandalous stories while still maintaining a respectable moral distance'. ${ }^{44}$

Pointing out the peculiarities of Smith's offers of marriage from various young men was one way that the colonial press could indulge in sensation vis-à-vis asserting a sense of

\footnotetext{
${ }^{39}$ Age, 23 September 1864, p.5.

${ }^{40}$ SMH, 23 September 1864, p.5.

${ }^{41}$ Goulburn Herald, 22 May 1861, p.2.

${ }^{42}$ Herald (Melbourne), 14 May 1861, p.5.

${ }^{43}$ South Australian Advertiser, 29 November 1864, p.2.

${ }^{44}$ Lauren Harmsen Kiehna, 'Sensation and the Fourth Estate: "The Times" and the Yelverton Bigamy Trials', Victorian Periodicals Review, Vol. 7, no. 1, 2014, p.101; Glasgow Herald, 23 December 1862, p.2.
} 
cultivation and moral superiority. Following her trial, it was reported that Smith had found refuge in the south of England after receiving many 'frivolous' letters asking for her autograph and 'no less than ten' offers of marriage. ${ }^{45}$ Thereafter, whenever a 'murderess' was met with suitors, newspapers throughout Australia and New Zealand often harkened back to Smith as a chief instigator of such moral depravity among men.

Cases that revived Australian interest in the Smith story included the 1865 case of Constance Kent, who confessed to murdering her half-brother in 1860 when she was sixteen years old; the 1886 'Pimlico Poisoning Mystery' in London, where Adelaide Bartlett was accused but found not guilty of poisoning her husband; and the 1889 trial of Florence Maybrick, a young American woman found guilty of murdering her husband by arsenic poison in Liverpool. The women at the centre of each case were each met with a lurid fascination by men not only because of their youth and gender, but also because they escaped the gallows. In covering the Kent case, the Empire, Age, and the Mercury all drew on what the Saturday Review called 'whitewashing', or the pitying of criminals and the glossing over of their defects because of their eminence, charm, and beauty. ${ }^{46}$

Bewilderment over the phenomenon coincided with alarm over the celebration of criminality in that people carrying away 'relics of murderers' and offering marriage to Smith revealed the 'hideous symptoms of popular feeling' ${ }^{47}$ Smith was the object of 'loving pity' from young men who 'longed to be the recipients of that sweet tenderness with which she had shown she could love'. ${ }^{48}$ When Kent was released from prison in 1885, the West Australian wrote that she, like Smith, was 'certain to get offers of marriage' because 'abnormal female criminals always do'. ${ }^{49}$ The Brisbane Courier also remarked in 1887 that Smith and Kent lingered long in the memories of 'middle aged men'. ${ }^{50}$ Australian papers also published the Pall Mall Gazette's sardonic take on the 'seventeen' offers of marriage received by Bartlett. ${ }^{51}$ Portraying Smith and Bartlett as kinds of marketable commodities available to men-free for observers to

\footnotetext{
${ }^{45}$ Mount Alexander Mail, 27 November 1857, p.3.

${ }^{46}$ Empire, 29 August 1865, p.2; Age, 30 August 1865, p.7; Mercury, 29 September 1865, p.3. The Saturday Review of Politics, Literature, Science and Art: Vol. XIX (London: Saturday Review Office, 1865), 17 June 1865, pp.721-722.

47 Quoted in Empire, 29 May 1867, p.2.

${ }^{48}$ Empire, 29 August 1865, p.2; Age, 30 August 1865, p.7; The Saturday Review of Politics, Literature, Science and Art: Vol. XIX (London: Saturday Review Office, 1865), 17 June 1865, pp.721-722.

${ }^{49}$ West Australian, 18 September 1885, p.3.

${ }^{50}$ Brisbane Courier, 24 March 1887, p.2.

${ }^{51}$ For example, see Port Augusta Dispatch, Newcastle and Flinders Chronicle, 31 May 1886, p.2; Daily Telegraph (Sydney), 5 June 1886, p.9; West Australian, 8 June 1886, p.3; Goulburn Herald, 12 June 1886, p.6; Burrowa News, 18 June 1886, p.4; Weekly Times (Melbourne), 19 June 1886, p.7; Glen Innes Examiner and General Advertiser, 29 June 1886, p.6; Geelong Advertiser, 17 July 1886, p.2.
} 
cast judgement on and fixate upon sexually - the paper wrote that Bartlett had 'the matrimonial advantage of some thousands of pounds and a most bewitching pair of eyes'. 'She is also an attentive and experienced sick nurse', it wrote, 'whose experiences of the dangers of using chloroform are sufficiently painful to deter her from practising with that drug upon a second husband'. 52

Maybrick's case ignited significant public debate in Britain over the severity of her death sentence (which was later reduced to life imprisonment) ${ }^{53}$ Reports of an 'increase of husband poisoning' and accounts of 'female poisoners' across metropolitan and colonial newspapers following the Maybrick trial revived a 'languid curiosity' in Smith's story and drew attention to Maybrick's infidelity. ${ }^{54}$ For Maybrick's sympathisers though, proof of adultery or sexual misconduct was not tantamount to proof of murder, but it did little to deter media outlets from capitalising on the public hearsay that eventuated. ${ }^{55}$ Many Australian newspapers compared Maybrick to Smith in that both claimed to have used arsenic for their complexion and both cases were heavily reliant on circumstantial evidence. Some, like the Age and the West Australian, felt that the Maybrick case would have resulted in a 'not proven' verdict if tried in Scotland and suggested that the English criminal system lacked an 'intermediate' stage between guilt and innocence. ${ }^{56}$ Adelaide newspapers were notably more certain of Maybrick's guilt, copying reports from British papers and reporting that the Smith and Maybrick trials highlighted how 'female poisoners' were exempt from judicial punishment, and that Smith was guilty of murdering L'Angelier but 'got off' because 'the man had treated her scandalously, and the general feeling was that he richly deserved his fate'. ${ }^{57}$ Questioning the public's sympathy for women criminals, one letter to the editor of the South Australian Register argued that 'all lies' were manufactured on Maybrick's behalf. 'My opinion in both cases is like an old Scotch Judge's when asked his private opinion on the famous Madeline Smith case [sic]. His reply was- "It is a case that you could hang her first and try her afterwards"., 58

\footnotetext{
${ }^{52}$ Pall Mall Gazette, 20 April 1886, p.3.

${ }^{53}$ Bridget Walsh, Domestic Murder in Nineteenth-Century England: Literary and Cultural Representations (Surrey, UK and Burlington, US: Ashgate, 2014), p.128.

54 James Beresford Atlay, Famous Trials of the Century (London: Grant Richards, 1899), pp.111-112. For reports on the 'increase in husband poisoning', see Argus, 14 September 1889, p.4; Brisbane Courier, 19 September 1889, p.7. For 'female poisoners', see Port Melbourne Standard, 21 September 1889, p.3; The Telegraph (Brisbane), 20 September 1889, p.2; Geelong Advertiser, 21 September 1889, p.2.

${ }_{55}$ Walsh, Domestic Murder in Nineteenth-Century England, pp.128-129.

${ }^{56}$ Age, 28 August 1889, p.4; West Australian, 16 September 1889, p.2.

${ }^{57}$ Advertiser (Adelaide), 8 October 1889, p.5; Express and Telegraph, 8 October 1889, p.3; South Australian Chronicle, 12 October 1889, p.7. See also Evening Journal (Adelaide), 25 October 1889, p.2; Adelaide Observer, 9 November 1889, p.40.

${ }^{58}$ South Australian Register, 6 January 1890, p.6.
} 
Many colonial newspapers extracted the Argus's 'increase in husband poisoning' narrative. The Argus wrote that recourse to using 'fly papers' and 'white powder' (to murder one's spouse) was not uncommon among upper classes in Britain when marriage became 'intolerable'. ${ }^{59}$ The conservative newspaper's foray into sensationalist journalism was reflective of the growing trend of 'New Journalism' in the 1880s. While 'New Journalism' was widely employed, not all journalists took kindly to the blurring of the boundaries between the news and the novel. The Press in Christchurch was particularly incensed by the Argus's attempts to stir a moral panic, writing:

We have no hesitation in saying that all this is either sensational "fudge" — written merely to keep up to its normal standard of "spiciness" a column which has already made a name for itself in that respector else it is the product of a very morbid and mistaken way of looking at things... There is absolutely no evidence... that such cases are otherwise than very rare, comparatively speaking. The extraordinary excitement which such a case always produces, as, for instance, the trial of Mrs Maybrick, or Mrs Bravo, or Madeleine Smith... is in itself sufficient proof of the rarity of the offence. ${ }^{60}$

While suggestions of increases in 'husband poisoning' might have represented Australasian coverage of the Smith case at its most extreme, the scores of reports centred on Smith's later whereabouts also intrigued colonial readers and reflected the growing trend of reporting on 'human interest' stories. ${ }^{61}$

The Smith trial also aroused some dispute over capital punishment. After Louisa Collins, a mother of ten, was sentenced to death in Darlinghurst, New South Wales, in 1889 for the murder of her two husbands, many lent their voices to the debate over capital punishment for women in Australia. It was noted that Collins's calm courtroom demeanour was very similar to Smith's, and one letter to the editor of the Sydney Morning Herald called for an amendment of the law to include the Scottish verdict of 'not proven' after three of the four trials of Collins had failed to reach a verdict. ${ }^{62}$ Reactions to Collins's eventual death sentence were polarised, and comparisons between her, Smith, and Maybrick-whose trial occurred only months after Collins's sentence - made reference to the sympathetic treatment toward women facing the gallows. Arguments against Collins's sentence ranged from appeals for a reprieve on the grounds of insanity to suggestions that her guilt could not be surmised by the abundance of

\footnotetext{
${ }^{59}$ Argus, 14 September 1889, p.4.

${ }^{60}$ The Press, 26 September 1889, p.4.

${ }^{61}$ Matthew Rubery, The Novelty of Newspapers: Victorian Fiction after the Invention of the News (Oxford: Oxford University Press, 2009), p.84.

${ }^{62}$ SMH, 5 January 1889, p.8.
} 
circumstantial evidence. ${ }^{63}$ The issue of her gender, like Smith's and Maybrick's, transcended both sides of the debate. Whereas some of her supporters thought that her life should be spared because she was a mother and a woman, detractors also emphasised her 'silenced stoicism' in court and her failure to adhere to concepts of womanhood that 'expected a wife to take care of her husband and children', as Wendy Kukulies-Smith and Susan Priest note, to denounce her as 'unwomanly'. ${ }^{4}$

Much has been written about the role of gender bias in the application of the law in nineteenth-century Britain. Carol Smart has argued that women offenders were 'doubly damned' because crimes committed by women were far less frequent than those committed by men, thus making them relatively more noteworthy and sensational. ${ }^{65}$ In a study of nineteenthcentury female poisoners, Randa Helfield argues that, because their fate was driven by the 'cultural stereotypes of the men' who applied the law, the presumption of innocence was stronger with respect to women than men, and thus, 'even in cases where women were convicted, the notion that they were somehow not fully responsible for their actions diminished their culpability and helped save their lives ${ }^{66}$ More recently, historians have assessed gender bias as part of a myriad of factors that influenced courtroom decisions, such as the degree of violence or the relationship between the victim and the assailant. ${ }^{67}$ With relation to the Collins case, it appeared that some colonial observers saw through the supposed biases that condemned Collins and spared Smith and Maybrick. 'If Mrs. Collins, terrible, unpicturesque, plain Mrs. Collins, perished justly', the Brisbane Courier wrote, 'then Mrs. Maybrick, good-looking, welldressed, pathetic Mrs. Maybrick, would perish justly'. ${ }^{68}$ Outraged by the sympathy afforded to women by legal men, the Age asked derisively, 'what man... would find it in his heart to put a rope round a swan-like neck of Lucretia [sic] Borgia'... 'did not a jury of Scotchmen recommend the cold blooded Madeleine Smith to mercy' ${ }^{69}$ In New Zealand, the Evening Star

\footnotetext{
${ }^{63}$ Wendy Kukulies-Smith and Susan Priest, "No Hope of Mercy” for the Borgia of Botany Bay: Louisa May Collins, The Last Woman Executed in NSW, 1889', Canberra Law Review, Vol. 10, no. 2, 2011, p.155.

${ }^{64}$ Kukulies-Smith and Priest, "No Hope of Mercy", pp.148, 157.

${ }^{65}$ Carol Smart, Women, Crime and Criminology: A Feminist Critique (London: Routledge \& Kegan Paul, 1977), p.34. See also Randa Helfield, 'Female Poisoners of the Nineteenth Century: A Study of Gender Bias in the Application of the Law', Osgoode Hall Law Journal, Vol. 28, no. 1, 1990, p.55.

${ }^{66}$ Helfield, 'Female Poisoners', p.101.

${ }^{67}$ Barry Godfrey, Stephen Farrall, and Susanne Karstedt, 'Explaining Gendered Sentencing Patterns for Violent Men and Women in the Late-Victorian and Edwardian Period', British Journal of Criminology, Vol. 45, no. 5, 2005, p.717; Marion Pluskota, 'Petty Criminality, Gender Bias, and Judicial Practice in Nineteenth-Century Europe', Journal of Social History, Vol. 51, no. 4, 2018, p.718.

${ }^{68}$ Brisbane Courier, 17 August 1889, p.4.

${ }^{69}$ Age, 15 April 1893, p.8. The newspaper's remarks came as a reaction to news that baby farmer John Makin was sentenced to death for the murder of an infant in Sydney in 1893, while his wife and accomplice, Sarah, was spared.
} 
similarly called for equal punishment for men and women, and felt that Smith merely escaped capital punishment because of her beauty. ${ }^{70}$ When the issue was brought up at the National Council of Women in New Zealand in 1898, one delegate thought that the fact that Smith lived a good life after the trial (and supposedly one in the colonies) was a great argument in favour of capital punishment. ${ }^{71}$

The Madeleine Smith case provoked wide-ranging debates in Australian newspapers about what femininity meant in a colonial context. Newspapers combined a peculiar interest in Smith's appearance and manner with a need to maintain distance from the cult of sensationalism and the worshipping of female criminals that was said to be pervading Britain. Concerns about the corrupting influences of female criminality in Britain — and the need to safeguard the colony from them-informed debates about Scottish marriage laws, Smith's education, and capital punishment, and were materialised through the works of Caroline Harper Dexter and Ellen Elizabeth Ellis. As the next section of this chapter finds, fascination with the appearance, manner, and sexuality of criminals could also be tied to concepts of white Australian masculinity.

\section{The Tichborne Claimant}

Unlike the Madeleine Smith case, histories of the Tichborne case have been largely indifferent to the role of gender in analysing both how case was represented in the media and how people responded to it. ${ }^{72}$ Arguments surrounding the stereotypes of Australia as degenerative went hand-in-hand with gendered discussion on the Claimant's character and appearance. In assessing coverage of the case in Australia, it is thus important to acknowledge how colonial gender constructions were informed by, yet differed from, those in Victorian Britain. Many scholars have examined how the concepts of empire and gender were inextricably linked; they ensured, enhanced, and projected one another. John Tosh writes that empire 'was a man's business' both through its acquisition and control and through its place in the popular imagination whereby 'men who chose colonial careers or set off in search of adventures

\footnotetext{
${ }^{70}$ Evening Star, 12 October 1889, p.2.

${ }^{71}$ Press (Christchurch), 30 April 1898, p.6.

${ }^{72}$ A notable exception is chapter one of Rebecca Stern, Home Economics: Domestic Fraud in Victorian England (Columbus: Ohio State University Press, 2008).
} 
overseas were making a statement about their masculinity'. ${ }^{73}$ Ann Laura Stoler similarly notes that empire 'provided the fertile terrain on which bourgeois notions of manliness and virility could be honed and put to patriotic test' ${ }^{74}$ In the media, representations of Australians as the figurative sons of a paternal Britain were synonymous with images of the Australian landscape as a place of exile, belonging, opportunity, and threat, 'animated by man's desire' - in Kay Schaffer's view- to tame it. ${ }^{75}$

Such conceptions of a hypermasculine Australia pervaded coverage of the Tichborne case in Britain and were typified by the Claimant himself. Although life in the colony was far from easy, the Claimant noted, he was proud of his Australian background and spoke fondly of his time there. 'These were the happiest years of my life', he declared, 'it is very different to what it is in England... there you can go and hunt or shoot when you like'. ${ }^{76}$ He advertised the colony during his stumping tour as a place for the bold, brave, and hardworking. ${ }^{77}$ Hunting and butchering, already imbrued as cultural symbols of British manliness, were central to colonisation. They represented in a settler colonial context the idea of 'improving' the land by introducing exotic game animals, as well as the conquering of the land and its resources as a show of masculinity in relation to colonised men. ${ }^{78}$ For supporters, the Claimant's sporting flair both affirmed and challenged traditional Victorian ideals of what an aristocratic gentleman should be. ${ }^{79}$ The Claimant won favour among the Hampshire gentry, Kent argues, by his 'gentlemanly' expertise in hunting, fishing, butchering, and horse-riding; his 'eating, drinking, and sporting tastes made him the sort of gentleman they could warm to' ${ }^{80}$

Depictions of the Claimant in the British newspaper press also correlated gender with national stereotypes to show how the masculine lust for adventure could be taken too far while living in the Australian bush. The Spectator described him as an 'uncultivated, fat, hard drinking butcher', 'slow of impulse', and habituated during his time in Australia to 'apathetic, lethargic' and 'lazy enjoyment'. He was 'incomplete of mind' and 'uneducated' yet, akin to Madeleine

\footnotetext{
${ }^{73}$ John Tosh, Manliness and Masculinities in Nineteenth-Century Britain (Harlow: Pearson Education Limited, 2005), p.193.

${ }^{74}$ Ann Laura Stoler, 'Cultivating bourgeois bodies and racial selves', in Catherine Hall (ed.), Cultures of Empire (New York: Routledge, 2000), p.107.

${ }^{75}$ Kay Schaffer, 'Women and the Bush: Australian National Identity and Representations of the Feminine' Antipodes, 1989, Vol. 3, no. 1, 1989, p.8.

${ }^{76}$ SMH, 12 May 1873, p.4.

${ }^{77}$ Ibid.

${ }^{78}$ Kate Hunter, Hunting: A New Zealand History (Auckland: Random House New Zealand, 2009), pp.31, 46; Woollacott, Gender and Empire, pp.71-72.

${ }^{79}$ Christopher Kent, 'Victorian Self-Making, or Self-Unmaking? The Tichborne Claimant Revisited', Victorian Review, Vol. 17, no. 1, 1991, p.31.

${ }^{80}$ Ibid, pp. 25, 30 .
} 
Smith's manner at the dock, 'as cool and impassive as the Emperor Napoleon'. ${ }^{81}$ Edward Kenealy also did not shy away from discussing the Claimant's 'hoarseness', 'roughness', 'gruffness', and 'grossness' in the civil court, describing him as 'about as unpresentable and unlikeable a person as you can well imagine'. ${ }^{82}$ Some Australian newspapers concurred, including the Northern Miner in Queensland, which felt that the Claimant and his supporters showed how men can lose the 'power of speaking or writing the English language' and gradually fall into the habit of using a 'bastard species of cockney dialect' after a few years in the Australian colonies. 'The majority of colonists are strange hybrids, a compound of bushranger, digger, and cattle-duffer', the paper wrote. ${ }^{83}$

As Penny Russell notes, 'savagery' in the European imagination was understood not just in racial terms to identify disposed Aboriginal Australians but also 'glimpsed in the foulmouthed convict' or in the 'uncouth gold-digger' ${ }^{84}$ For British newspapers covering the case, the claimant's vulgar and gluttonous manner was synonymous with a seemingly adventurous and unruly life in Australia, placing him quite literally on the fringes of Victorian respectability. As Roe points out, for British supporters, the Claimant's life in Australia explained how a 'slim young Roger had transformed into a man-mountain, with all his strangeness of behaviour and memory'; 'it vested him with an aura of appealing delight'. 85 'Tichbornites' in Britain heralded the case as a kind of socio-political underdog story; for detractors, his return to England amplified wider anxieties about those men who spent time in the colonies and tried to return home to live as 'gentlemen' again. ${ }^{86}$ But for white Australian supporters, it also had a nationalistic facet that represented a sense of pride in the disparity between the misfit Australian bushman and the learned English gentleman stereotypes.

Isa Menzies argues that the 'underdog' narrative is a familiar convention in Australian popular culture rooted in the sympathetic portrayal of low-offending convict transportees in

\footnotetext{
${ }^{81}$ Quoted in $S M H, 8$ May 1872, p.3.

${ }^{82}$ Edward Kenealy (ed.), The Trial at Bar of Sir Roger C. D. Tichborne, Bart., in the Court of Queen's Bench at Westminster, before Lord Chief Justice Cockburn, Mr. Justice Mellor, and Mr. Justice Lush, for Perjury: Vol. IV (London: "Englishman" Office, 1877), pp.102, 296. See also John T. Morse, Jr., Famous Trials: The Tichborne Claimant, Troppmann, Prince Pierre Bonaparte, Mrs. Wharton, The Meteor, Mrs. Fair (Boston: Little, Brown, and Company, 1874), pp.102, 237, 296.

${ }^{83}$ Quoted in Mackay Mercury and South Kennedy Advertiser, 14 March 1874, p.2.

${ }^{84}$ Penny Russell, Savage or Civilised? Manners in Colonial Australia (Sydney: NewSouth, 2010), p.5.

${ }^{85}$ Michael Roe, 'Foreword: Australia and the Tichborne Case', in Hugh Anderson (ed.). Baronet or Butcher? The Trials of the Tichborne Claimant (Victoria: Red Rooster Press, 1999), p.ix.

${ }^{86}$ Lisa Eutsey, 'The Rhetoric of Empire and the Fiction of Anthony Trollope', PhD Thesis, Pennsylvania State University, 2009, p.164.
} 
literary discourse and in which 'masculinity, whiteness and the rural' are positioned as central. ${ }^{87}$ Like the 'little boy from Manly' stereotype, as analysed in Chapter Two, the Claimant embodied the schematic of 'success against the odds'. Everest-Phillips notes that Australians generally 'admired a local boy battling social pretensions in the 'mother country', and respected the Claimant's nerve and fighting spirit' ${ }^{88}$ While newspaper coverage suggests that many Australians grew weary of the case as the trials dragged on, the unlikeliness of the Claimant's story and success made his supporters all the more fervent toward the cause. That many sympathisers in both Britain and Australia identified with the Claimant's rugged, masculine image propagated in the press is demonstrative of Menzies's argument that the underdog schematic does not necessarily 'preclude the type of rugged masculinity that is central to constructions of Australian identity' but rather serves to 'reinforce' it. ${ }^{89}$

Although discrepancies in manner between the learned Roger Tichborne and the illiterate Claimant were universally commented on, a number of Australian newspapers suggested that such retrogression in Victorian 'gentlemanly' conduct was not entirely undesirable. Writing for the Pastoral Times, one supporter and old acquaintance of the Claimant's noted that he did not believe that his friend was the genuine heir because he was 'too Australian'. ${ }^{90}$ The Claimant allegedly seized and drank an entire bottle of port at a restaurant in England 'which no gentleman would do'. ${ }^{91}$ 'Gentlemen in the Australian colonies are so accustomed to help themselves that it is no wonder when they get home 'midst the conventionalities of society there, they forget they are not in Australia', the paper wrote. ${ }^{92}$ Although conceding that 'there are no doubt many cases of degraded gentlemen in Australia', the Argus often wrote favourably about the Claimant and the popularity the case generated. ${ }^{93}$ Early in the case, the paper suggested:

The new baronet is in the prime of life, a portly gentleman weighing 250lb., but of an active, athletic frame, a great lover of horses and field sports generally; and, notwithstanding his eighteen stone weight, he is withal a splendid rider, having apparently spent more of his life in the saddle than on foot. He is exceedingly kind and amiable, and possessed of that great requisite-common sense. Although not

\footnotetext{
${ }^{87}$ Isa Menzies, 'Horses Down Under: The Underdog Schematic Narrative Template and Australian Nationalism', Journal of Australian Studies, Vol. 45, no. 1, 2021, pp.18-19, 32.

${ }^{88}$ Max Everest-Phillips, 'The 1871 'Tichborne Claimant' medal and the forging of Australia's identity', Journal of the Numismatic Association of Australia, Vol. 24, 2013, p.3.

${ }^{89}$ Menzies, 'Horses Down Under', p.23.

${ }^{90}$ Quoted in Wallaroo Times and Mining Journal, 13 April 1872, p.2.

${ }^{91}$ Ibid.

92 Ibid.

${ }^{93}$ Argus, 7 March 1874, p.9.
} 
endowed with a large share of aristocratic polish, he will, we are sure, make a far better citizen and more pleasant neighbour than many a more elegant gentleman. ${ }^{94}$

Others chose not to associate the Claimant's ungentlemanly manner with Australia. Reporting to the Kilmore Free Press, Patrick McManus, a former employer of the Claimant at a Reedy Creek butchery who gave evidence against him, noted that the Claimant was the 'reverse of gentlemanly in his conversation' and suggested that his coarseness and vulgarity were innate. ${ }^{95}$ Conversely, another contributor to the Daylesford Mercury claimed to have known the Claimant in Hobart Town as a gentleman and took issue with how men who worked in the butcher's trade more generally had become unfairly characterised by 'low, vulgar' stereotypes. ${ }^{96}$

Just as many of Madeleine Smith's supporters were men, it has been said that the Tichborne movement in Britain was largely male in composition. The most active Tichbornites, as McWilliam has examined, were all men, and enfranchisement for women, despite being one of the aims of Kenealy's Magna Charta Association, was not strongly pushed. ${ }^{97}$ Such an assertion is consistent with the view that popular politics became increasingly masculinised over the nineteenth century, as expressed in movements like Radicalism which largely concerned itself with 'working men'. ${ }^{98}$ Similarly, Roe suggests that the 'female element' of the Tichborne movement was not always obvious. ${ }^{99}$ One explanation for the Claimant's lack of support among women was forwarded during the criminal trial by Kenealy, who suggested that the Claimant did not have 'any personal favours likely to recommend him to either the female or to the generous of his own sex'. 'Women, as we know, stick together', he argued, and the Claimant's public and almost boastful admission to sexual relations with Lady Radcliffe was 'enough to excite all female influences against him'. ${ }^{100}$ Rebecca Stern points out that the seduction story exposed 'a gentlewoman to the scrutiny and derision of the public', giving 'common mouths' and 'bawdier' members of the population access to Lady Radcliffe's name and providing them with salacious fantasies about her body. ${ }^{101}$ Like the reading of Madeleine Smith's letters in court

\footnotetext{
${ }^{94}$ Argus, 8 January 1867, p.5.

${ }^{95}$ Quoted in Argus, 10 July 1868, p.5.

${ }^{96}$ Quoted in Advocate, 20 June 1874, p.15.

${ }^{97}$ Rohan McWilliam, The Tichborne Claimant: A Victorian Sensation (London: Hambledon Continuum, 2007), pp.250-251.

${ }_{98}$ See Keith McClelland, 'Rational and Respectable Men: Gender, the Working Class, and Citizenship in Britain, 1850-1867', in Laura L. Frader and Sonya O. Rose (eds.), Gender and Class in Modern Europe (Ithaca and London: Cornell University Press, 1996), p.291; Rohan McWilliam, Popular Politics in Nineteenth-Century England (London; New York: Routledge, 1998), p.75.

${ }^{99}$ Michael Roe, Kenealy and the Tichborne Cause: A Study in Mid-Victorian Populism (Melbourne: Melbourne University Press, 1974), p.66.

${ }^{100}$ Kenealy (ed.), The Trial at Bar of Sir Roger C. D. Tichborne: Vol. III, p. 259.

${ }^{101}$ Stern, Home Economics, pp.37, 40, 43.
} 
(and their later publication), it served to publicise the private and reinforced how both the courtroom and the press could operate as arenas for humiliation.

The Claimant's perjurious seduction allegations lost him sympathy in Britain, and Australian newspapers that denigrated his cause also cited his 'ungentlemanly' treatment of Lady Radcliffe in court as damning, whether the allegations were true or not. The Ovens and Murray Advertiser lost all respect for the Claimant upon learning about the admission, and the Armidale Express wrote that the admission was the 'worst feature of his conduct' and 'if that is proved to be false no one will pity him, however severe his sentence may be'. ${ }^{102}$ Celebrating his conviction, the Weekly Times simply called him an imposter, perjurer, and 'vilifier of women'. ${ }^{103}$ Some, including the (initially) pro-Claimant Mercury, defended the Claimant's seduction story, noting that it was 'forced out of him' in court under 'extreme pressure'. ${ }^{104}$ But the general reaction in Australia to the salacious facets of the case was less pronounced than in Britain. Most newspapers chose not to weigh in on the matter and instead copied entire trial reports.

Australian newspapers seldom commented on gender discrepancies among those who supported the Claimant; affidavits submitted to newspapers came principally from men or used pseudonyms to avoid name recognition. That supporters of the Tichborne movement in both Britain and Australia were predominantly men is also consistent with Schaffer's argument that national identity and Australian character were masculine constructions which excluded women and were defined in relation to men. ${ }^{105}$ Identifying with the Claimant's underdog narrative meant identifying with the masculine bushman stereotype that he and the press perpetuated. Still, support for the Claimant in Australia was not exclusively male. Among the Australian supporters was Mary (née Christina) McMillan, the widow of Angus McMillan, a Scottish explorer responsible for the dispossession and massacre of indigenous Gunai people in Gippsland in the early 1840s. ${ }^{106}$ Mary McMillan recognised the Claimant as Orton, a "well-bred man' and a friend of her husband's during their time at Bushy Park station in Victoria in the

\footnotetext{
102 OMA, 10 April 1872, p.2; Armidale Express and New England General Advertiser, 13 April 1872, p.2.

${ }^{103}$ Weekly Times, 7 March 1874, p.8.

${ }^{104}$ Mercury (Hobart), 8 September 1871, p.2.

${ }^{105}$ Kay Schaffer, Women and the Bush: Forces of Desire in the Australian Cultural Tradition (Cambridge: Cambridge University Press, 1988), p.4.

${ }^{106}$ Cheryl Glowrey, 'McMillan, Angus (1810-1865)', Australian Dictionary of Biography, National Centre of Biography, Australian National University, https://adb.anu.edu.au/biography/mcmillan-angus-2416, published online 2017, accessed 13 April 2021.
} 
early 1860 s. ${ }^{107}$ The testimony of the 'honoured old lady' was enthusiastically welcomed by Le Sage and his Gippsland supporters. ${ }^{108}$

Despite the largely masculine make-up of Tichbornism in Britain, affidavits from 'respectable' Australian women were published alongside McMillan's by the Claimant's publicist, Robert Gurnell, in an effort to release the Claimant from prison. ${ }^{109}$ Indeed, Australian women's voices gave the Tichborne movement veracity in Britain. Kenealy emphasised that women were more apt at identifying faces and recollecting events than men. 'Their memories being less loaded with business, are usually more tenacious', he declared. ${ }^{110}$ A common sentiment shared by the Australian women highlighted in Gurnell's publication, as William Cresswell supporter Eliza Walsh typified, was the desire for 'fair play' and the needs to meet the ends of justice irrespective of the ill characterisations that were promulgated about the Claimant in the press. ${ }^{111}$ Like those women in Britain who concurred with Henriette Tichborne's recognition of the Claimant as her son as decisive and who shouted 'poor thing' at his rallies, women's voices gave the movement much-needed and increasingly rare support among a constituency that the Claimant had alienated and the press had excluded. ${ }^{112}$

Mary Ann Bryant, the Claimant's wife, was also excluded in much of the coverage of the case, and histories of the case continue to give her scant attention. Bryant was a young, illiterate Roman Catholic from Ireland when she married the Claimant in Wagga Wagga in January $1865 .{ }^{113}$ A daughter, Theresa, was born in 1866, and they accompanied the Claimant on his journey from Australia. Bryant subscribed to the Tichborne cause from its outset. Shipping records listed her as 'Lady Tichborne', and Theresa was often named 'Little Miss Tichborne' during their stay with Henriette. ${ }^{114}$ Save for being the subject of Frank Hutchinson's theatre production and despite being a staunch advocate for her husband until their divorce in 1880, Bryant remained on the periphery in the media. ${ }^{115}$ Whereas some British detractors, including the criminal trial's judge, Alexander Cockburn, found it incongruous that a man of Roger Tichborne's position would marry an illiterate domestic servant of low rank and attempt

\footnotetext{
${ }^{107}$ R. M. Gurnell, A Critical Review of the Tichborne Trial (London: W. Wilfred Head, 1876), pp.88-89.

108 Gippsland Times, 1 September 1874, p.4.

${ }^{109}$ Gurnell, A Critical Review of the Tichborne Trial, pp.87-88; Age, 10 May 1884, p.37.

${ }^{110}$ Kenealy (ed.), The Trial at Bar of Sir Roger C. D. Tichborne: Vol. IV, pp.225-226.

111 Southern Argus, 26 June 1884, p.2.

${ }^{112}$ McWilliam, The Tichborne Claimant, p.263.

${ }^{113}$ Evening News (Sydney), 16 August 1871, p.3; South Australian Register, 13 July 1878, p.6; McWilliam, The Tichborne Claimant, p.15.

${ }^{114}$ SMH, 1 September 1866, p.6; Argus, 8 November 1924, p.8.

${ }^{115}$ For evidence of Bryant's advocacy on behalf of the Claimant, see SMH, 15 May 1877, p.5. For news of their divorce, see $S M H, 5$ April 1880, p.5.
} 
to return to his 'native country' and resume his station, Australian newspapers appeared less scandalised by the concept. ${ }^{116}$ When the Claimant confessed to being Arthur Orton in 1895, most Australian newspapers reported on his earlier marriage to Bryant as if they had not already known she existed. They were more bewildered by Bryant's background later that year when it was alleged by Jean Luie that she had been courted by William Cresswell before the Claimant married her 'to preserve her knowledge to himself' instead. ${ }^{117}$ Although not the subject of this study, Theresa continued to insist on her family's rights to the Tichborne funds into the twentieth century, albeit through more extreme measures. These measures included an attempt to assassinate the Tichborne heir on his wedding day in 1912; a 12-month prison sentence in 1924 for writing threatening letters to the Tichborne family; and claims in gaol that her father admitted in 1885 to shooting the real Arthur Orton dead in Wagga Wagga in $1866 .^{118}$

Like Madeleine Smith, the Claimant's body was the focal point of the Tichborne case and central to debate over his identity. While discrepancies between his and Roger Tichborne's ears, birthmarks, and tattoos were contested pieces of evidence in court, the Claimant's sizewhich almost doubled between his leaving Australia in 1866 and the beginning of his civil trial in 1872 - became the subject of widespread popular discourse across Britain. ${ }^{119}$ Newspapers often conflated his bulging appearance and excessive consumption habits with the notion of an uncouth and vulgar bushman returning to a life of luxury. In addition to calling into question his identity as Tichborne, his figure variously symbolised liberty and freewill in the colonies, as well as Victorian wealth (particularly as he became larger during his time at the Tichborne estates). ${ }^{120}$ Above all, as McWilliam points out, 'the fat person was a figure of fun' and a source of gags across the press; his ballooning size made him readily identifiable to observers. ${ }^{121}$

Denigrators used the Claimant's weight to criticise the Tichborne movement. The comic magazine, Punch; or, the London Charivari, was one of the Claimant's fiercest critics. Incorporating cartoons, parodies, pastiches, travesties, and satires, the London magazine was born out of satiric journalism and running social commentary. As a public figure, the Claimant

\footnotetext{
${ }^{116}$ The Tichborne Trial: The Summing Up of the Lord Chief Justice of England, Together with the Addresses of the Judges, the Verdict, and the Sentence, the Whole Accompanied by a History of the Case and Copious Alphabetical Index (London: Ward, Locke, and Tyler, 1874), pp.86-87.

${ }^{117}$ For example, see Daily Telegraph (Sydney), 20 May 1895, p.5.

${ }^{118}$ Adelong and Tumut Express and Tumbarumba Post, 3 October 1924, p.3. See also McWilliam, The

Tichborne Claimant, p.274; Roe, Kenealy and the Tichborne Cause, p.141.

${ }^{119}$ David Wayne Thomas, Cultivating Victorians: Liberal Culture and the Aesthetic (Philadelphia: University of Pennsylvania Press, 2004), p.88.

${ }^{120}$ McWilliam, The Tichborne Claimant, p.200.

121 Ibid.
} 
was derided in the paper as an immoral, a drunkard, and a 'Waggawock' (a play on words combining his Australian background with the titular monster in Lewis Carroll's 'Jabberwocky'), while his supporters were likened to animals and 'gentlemen of the pavement'. ${ }^{122}$ Punch's commercial rival, Fun, similarly depicted him as a giant jack-in-the(witness) box. ${ }^{123}$ Another rival, Judy, satirised the Claimant's efforts to raise funds after being made bankrupt by showing the overweight figure begging on the streets (see Figure 4). A sign on his chest reads, 'I am starving'. ${ }^{124}$

${ }^{122}$ McWilliam, The Tichborne Claimant, pp.207-208.

${ }^{123}$ Sean Grass, The Commodification of Identity in Victorian Narrative (Cambridge: Cambridge University Press, 2019), p.217.

${ }^{124}$ Judy, or the London Serio-Comic Journal, 24 April 1872, in Douglas Woodruff, The Tichborne Claimant: A Victorian Mystery (London: Hollis and Carter, 1957), p.227. 
This content is unavailable. Please consult the figure list for further details.

Figure 4: 'The Beggar's Petition', from Judy, or the London Serio-Comic Journal, 24 April 1872, in Douglas Woodruff, The Tichborne Claimant: A Victorian Mystery (London: Hollis and Carter, 1957), p.227.

British newspaper coverage of the case is saturated with language describing the Claimant as 'ugly' and 'fat'. Following his conviction, the Saturday Review questioned why many people often sympathised with a 'repulsive' criminal, let alone a 'grossly fat and utterly uneducated butcher'. ${ }^{125}$ Echoing the views of the Spectator, Frank Leslie's Popular Monthly in

${ }^{125}$ The Saturday Review of Politics, Literature, Science and Art: Vol. XXXVII (London: Saturday Review Office, 1874), 14 March 1874, p.330. 
the United States wrote that 'the fools who took a fat, living snob' for a 'lean, dead aristocrat' have only 'to thank their long ears for it' because 'no downright delusive appearance ever met their eyes'. ${ }^{126}$

For supporters in Britain, the Claimant's weight represented a 'jolly disregard' for thrift, self-discipline, and industriousness, Thomas argues. ${ }^{127}$ Kenealy acknowledged such stereotypes, describing the Claimant as a 'bullocky, fatty, hulking sort of a brute', and even attributed the Claimant's memory impairment and 'dulness [sic]' to his 'excessive fatness'. ${ }^{128}$ Supporters also pointed out that middle-aged stoutness was a Tichborne family peculiarity. ${ }^{129}$ Pro-Claimant songs and ballads made fun of the Claimant's appearance as an endearing feature in the Tichborne movement's strive for 'fair play'. ${ }^{130}$ For McWilliam, his size represented a form of resistance, a representation of the 'other' in Victorian culture, and a carnivalesque 'inversion of respectability'. ${ }^{131}$ Discipline over one's body was, as Joanne Ella Parsons argues, perceived as vital in 'fulfilling the strict boundaries of prescribed manliness'; failing to adhere to dietary and bodily restrictions, as the Claimant did, represented a rejection of Victorian notions of social acceptability. ${ }^{132}$ Such assumptions differed from how the Claimant wished to be seen: as a 'country gentleman' ${ }^{133}$ For all the ways the Claimant advertised colonial life as 'hard' and not for the fainthearted, his return to England showed how a bulky colonial 'bushman' might in turn infringe upon respectability's resources and lead a (well-earned, in his view) life of gluttony, laziness, and excess of which he had previously been deprived in the colony. ${ }^{134}$

Australian newspapers were less receptive to the notion that life in the 'bush' had turned the Claimant into a large brute, and they tended to place responsibility for his altered appearance on him alone. As the Queenslander reported, 'instead of being slim and good-looking, he is now fat and ugly... this is partly accounted for by the fact that he was never very attentive to these

\footnotetext{
${ }^{126}$ Frank Leslie's Popular Monthly: Vol. X-July to December, 1880 (New York: Frank Leslie's Publishing House, 1880), p.475.

127 Thomas, Cultivating Victorians, p.88.

${ }^{128}$ Kenealy (ed.), The Trial at Bar of Sir Roger C. D. Tichborne: Vol. IV, pp.102, 296. See also Morse, Jr., Famous Trials, pp.87, 154, 237.

${ }^{129}$ Gurnell, A Critical Review of the Tichborne Trial, p.91.

${ }^{130}$ For examples of ballads, see Hugh Anderson (ed.), Baronet or Butcher?

${ }^{131}$ McWilliam, The Tichborne Claimant, p.227.

132 Joanne Ella Parsons, 'Fosco's Fat: Transgressive Consumption and Bodily Control in Wilkie Collins' The Woman in White', in Joanne Ella Parsons and Ruth Heholt (eds.), The Victorian Male Body (Edinburgh: Edinburgh University Press, 2018), p.216.

${ }^{133}$ McWilliam, The Tichborne Claimant, p.202.

${ }^{134}$ SMH, 12 May 1873, p.4.
} 
things, but lived a wildish and vagabond life'. ${ }^{135}$ Most newspapers placed more attention on the Claimant's increasing weight after his return to England than on changes in his appearance that occurred during his time in Australia. The Ballarat Courier remarked that it would not be 'any real punishment to such a grossly fat man to exchange champagne and turtle for "skilly and burgoo", and the Maryborough Chronicle called him a 'mountain of flesh' recognisable in 'every part of the globe'. ${ }^{136}$ Despite supporting the Claimant, the Wallaroo Times noted that he did not help himself through his 'fat and bloated appearance'. ${ }^{137}$

The numerous colonial imitations of the London Punch that sprouted throughout the mid-late nineteenth century are demonstrative of how migrants to Australia brought British press traditions with them and applied them to local contexts. ${ }^{138}$ Born out of the networks of periodical publishing between metropole and colony, the Melbourne Punch (1855-1925), the first and most enduring of these colonial imitations, and the Sydney Punch (1864-1888) drew on the humour of the London Punch while lending their own unique voices to the Tichborne case. ${ }^{139}$ Anonymity was a key component in periodical journalism in the nineteenth century; it gave writers power to express their views freely without risking damage to their reputations or exposing them to charges of personal bias. ${ }^{140}$ Punch was no different. While editorial sections of newspapers reaffirmed a newspaper's stance (or lack thereof) on particular news items, cartoons, songs, poems, puns, caricatures, and other items of satire present in the Punch imitations allowed the periodicals to weigh in on the case in a far more vociferous, exaggerated, and provocative way than the more serious coverage of traditional newspapers. As such, the Claimant's appearance provided ample fodder for denigrations. Portraits of the Claimant first appeared in the Illustrated Australian News for Home Readers in $1867 .{ }^{141}$ Thereafter, the Sydney Punch made consistent gibes at the Claimant's speech, manner, and appearance through a weekly serial titled 'The true confession of Arthur Orton, commonly called Sir Roger Tichborne' from July-December 1872. The series told the story from Orton's perspective,

\footnotetext{
${ }^{135}$ Queenslander, 15 July 1871, p.8.

${ }^{136}$ Ballarat Courier, 9 April 1972, p.2; Maryborough Chronicle, Wide Bay and Burnett Advertiser, 5 March 1874, p. 2

${ }^{137}$ Wallaroo Times and Mining Journal, 4 April 1874, p.2.

${ }^{138}$ Simon Potter, News and the British World: The Emergence of an Imperial Press System (Oxford: Oxford University Press, 2003), pp.13-14.

${ }^{139}$ Mary L. Shannon, 'Colonial Networks and the Periodical Marketplace', in Joanne Shattock (ed.), Journalism and the Periodical Press in Nineteenth-Century Britain (Cambridge: Cambridge University Press, 2017), p.223.

140 James A. Secord, Victorian Sensation: The Extraordinary Publication, Reception, and Secret Authorship of Vestiges of the Natural History of Creation (Chicago and London: University of Chicago Press, 2000), pp.1819.

${ }^{141}$ Illustrated Australian News for Home Readers, 20 August 1867, p.8.
} 
emphasised his gluttony, characterised him as an incompetent political puppet from Wapping, and suggested that the Claimant was tutored to impersonate Tichborne by the Tichborne family's former servant, Andrew Bogle. ${ }^{142}$

Criticisms aimed at the Claimant's appearance stood alongside racist derisions of Bogle, a former slave from Jamaica. ${ }^{143}$ Bogle retired to Sydney after Roger Tichborne's disappearance, where he was informed about the Claimant, met him at the Metropolitan Hotel in Sydney, and after some initial doubt, agreed that he was indeed Roger Tichborne. He returned to England with the Claimant and became an important supporter of and key witness for the Claimant until his death in 1877. ${ }^{144}$ The Tichborne family quickly stopped Bogle's pension upon hearing of his support for the Claimant and refused to restore it until he changed his stance. ${ }^{145}$ Aside from supposition that he had tutored the Claimant into an impersonator to exact revenge on his former aristocratic employers, Bogle was widely perceived as a mistaken old man who had been duped, and British media outlets often alluded to his race to belittle the Tichborne cause. ${ }^{146}$ A comic alphabet wrote that 'B stands for Bogle, a darkly what of that, he swears he knew Sir Roger before he got so fat'. ${ }^{147}$ The Sydney Punch made similar remarks about Bogle by ridiculing his accent and denigrating his intellect on the basis of his skin colour. ${ }^{148}$ The Claimant 'has only one servant whom he can thoroughly trust', the paper wrote, 'a black man of the name of Bogle, who, being a most ferocious individual, and pugilistically [sic] inclined, is a constant source of terror to his master's enemies'. ${ }^{149}$

While the Sydney Punch castigated the Claimant through songs, poems, and jokes, the Melbourne Punch employed visual humour to belittle his cause and echo frustrations over how many were becoming fatigued by the case. The paper poked fun at the potential collapse of the Claimant's case in an April 1872 cartoon titled 'revenons à nos moutons' (meaning, 'back on topic') by depicting the Claimant as a now thin, emaciated figure cowering in a prison cell. ${ }^{150}$ A later cartoon shows that the Claimant 'has found Arthur Orton at last' by depicting the figure

\footnotetext{
${ }^{142}$ For example, see Sydney Punch, 25 July 1872, p.7.

143 Joy Lumsden, 'The True and Remarkable History of Andrew Bogle', Jamaican Historical Society Bulletin, Vol. 11, no 4, pp.34-43.

${ }^{144}$ McWilliam, The Tichborne Claimant, pp.17, 51, 101.

${ }^{145}$ Lumsden, 'The True and Remarkable History of Andrew Bogle', pp.34-43.

${ }^{146}$ Ibid. See also Everest-Phillips, 'The 1871 'Tichborne Claimant' medal', p.9.

${ }^{147}$ McWilliam, The Tichborne Claimant, pp.206-207.

148 Sydney Punch, 5 September 1872, p.2; 3 October 1872, p.2; 28 November 1872, p.2; 12 December 1872, p.2;

19 December 1872, p.1.

149 Sydney Punch, 23 May 1868, p.7.

${ }^{150}$ Melbourne Punch, 11 April 1872, p.1.
} 
gazing at his own reflection in a mirror. ${ }^{151}$ For both versions of the Punch, the Claimant's everexpanding size reflected the longevity of the case and the ridiculousness of his continued nourishment (and the unending preoccupation with his trial) in British society. Before the conclusion of the criminal trial, the Melbourne Punch jokingly predicted that those attending would be dead by the time it ended by depicting a courtroom full of skeletons (see Figure 5). An old and round Claimant is the only living figure that remains. ${ }^{152}$

This content is unavailable. Please consult the figure list for further details.

Figure 5: 'The End of the Tichborne Case', Melbourne Punch, 25 December 1873, p.6.

Like Madeleine Smith, the Claimant's body was also a key subject at various wax exhibitions across Australia. A life-size portrait of 'Arthur Orton alias Sir Roger Tichborne' was featured as part of Signor Ghiloni's exhibition, which toured across Australia during the

${ }^{151}$ Ibid, 11 July 1872, p.9.

${ }^{152}$ Ibid, 25 December 1873, p.6. 
1870s. ${ }^{153}$ At the travelling exhibition's New South Wales leg in 1874, the Claimant was declared the 'most conspicuous' among the waxworks due to his 'great size'. ${ }^{154}$ A replica of the Claimant was later shown at Sohier and Kreitmayer's exhibition in Sydney in $1885 .{ }^{155}$ At all of these shows, the Claimant was presented as a kind of outcast; a 'notorious' criminal who stood alongside figures such as Maria Ellen Kinder and the Kelly gang whose actions ought to be condemned but whose appearance ought to be made fun of or, like Madeleine Smith, enjoyed for one's untroubled amusement ${ }^{156}$ Similarly, 'porcine monstrosities of fat' at the cattle show in Sydney's Agricultural Hall in 1871 were affectionately likened to the Tichborne Claimant, as one Sydney Morning Herald correspondent reported, highlighting the Claimant's synonymity with burliness, as well as the public's fascination with his size. ${ }^{157}$

The Claimant's sexuality was also a prominent feature in discussions of the case. A medical examination showed that he suffered from a malformation of the genitals, which was made public during the criminal trial. ${ }^{158}$ The Claimant's supporters suggested that Roger Tichborne also possessed the malformation, and Kenealy called on one of Tichborne's fellow officers from the Dragoons to give evidence in court that Roger Tichborne was often mockingly referred to as 'small cock'. ${ }^{159}$ Despite having little bearing on the trial's outcome, the disclosure allowed denigrators of the Claimant to emasculate him through disparaging references to the size of his genitalia, akin to how denigrators of Smith debated the beauty of her physical features. Stern points out that the exposure of the Claimant's privates to the public gave the Crown the ability to reassert 'hierarchies of access' and work upon public investments in privacy. ${ }^{160}$ But the exposure also gave the public an opportunity to take gibes at the veracity of the Claimant's cause. In Britain, songs and jokes mocking how Henriette supposedly 'satisfied herself' upon recognising the Claimant on the basis of the malformation, along with the 1878 creation of a pornographic, 'adult males only' pro-Claimant pamphlet entitled The Tichborne Malformation, added a degree of voyeurism to the sensation already stirred by the Lady Radcliffe seduction story. ${ }^{161}$

\footnotetext{
${ }^{153}$ For example, see Weekly Examiner (Launceston), 10 March 1877, p.8; Express and Telegraph (Adelaide), 5 April 1879, p.2.

${ }^{154}$ Murrurundi Times and Liverpool Plains Gazette, 22 August 1874, p.4.

${ }^{155}$ SMH, 16 February 1885 , p.5.

${ }^{156}$ For example, see Bunyip, 20 August 1880, p.2

157 SMH, 14 March 1872, p.5.

${ }^{158}$ Roe, Kenealy and the Tichborne Cause, p.58.

${ }^{159}$ Kenealy (ed.), The Trial at Bar of Sir Roger C. D. Tichborne: Vol. II, p.46.

${ }^{160}$ Stern, Home Economics, p.44.

${ }^{161}$ Janet C. Myers, Antipodal England: Emigration and Portable Domesticity in the Victorian Imagination
} 
The scandal made its way into Australian newspapers through mediated trial reports, which euphemistically played down what the malformation was while commenting on the 'disgusting' way in which it was talked about in court by both sides of the argument. ${ }^{162}$ Interest in the salacious nature of the case had also been propagated by the Sydney Punch's 'true confession' series in 1872, which poked fun at the Claimant's lust for Lady Radcliffe in graphic, sensual detail. ${ }^{163}$ Writing about the matter in 1884, Melbourne's Herald suggested that Chief Justice Cockburn's denouncement of the case's imputation regarding the Claimant's malformation and Lady Radcliffe as 'being the most revolting suggestion he had ever heard in his life'... gave voice to the 'general public opinion' across the British world. ${ }^{164}$ Indeed, Australian newspapers did not take kindly to attempts to revive the salacious aspects of the case in Australia a decade later.

For example, Daniel Smith came to Australia from England in 1882 as an agent for the Tichborne Release Association, and became known in New South Wales as an advocate for the release of William Cresswell from the Parramatta Lunatic Asylum, believing Cresswell to be the real Arthur Orton. ${ }^{165}$ He gave a series of lectures in Sydney upon his arrival; the 'audience was not at all in unison' with Smith during his first lecture to 120 people at the Protestant hall in Sydney in April 1883, the Argus reported, but he continued to draw crowds throughout 1883. ${ }^{166}$ By February 1884, Smith-despite jostling with Cresswell advocate and politician Joseph Eckford on Cresswell's release-helped present a petition to the New South Wales parliament that carried 10,500 signatures supporting an inquiry into the Cresswell case. ${ }^{167}$ Part of Smith's efforts to mobilise a popular movement around Cresswell's release involved distributing The Tichborne Malformation across the colony, which was suppressed for being indecent. ${ }^{168} \mathrm{He}$ was quickly arrested and charged $£ 10$ for selling 'obscene printed matter', and women and children were warned not to buy copies of the pamphlet. ${ }^{169}$ His refusal to pay the

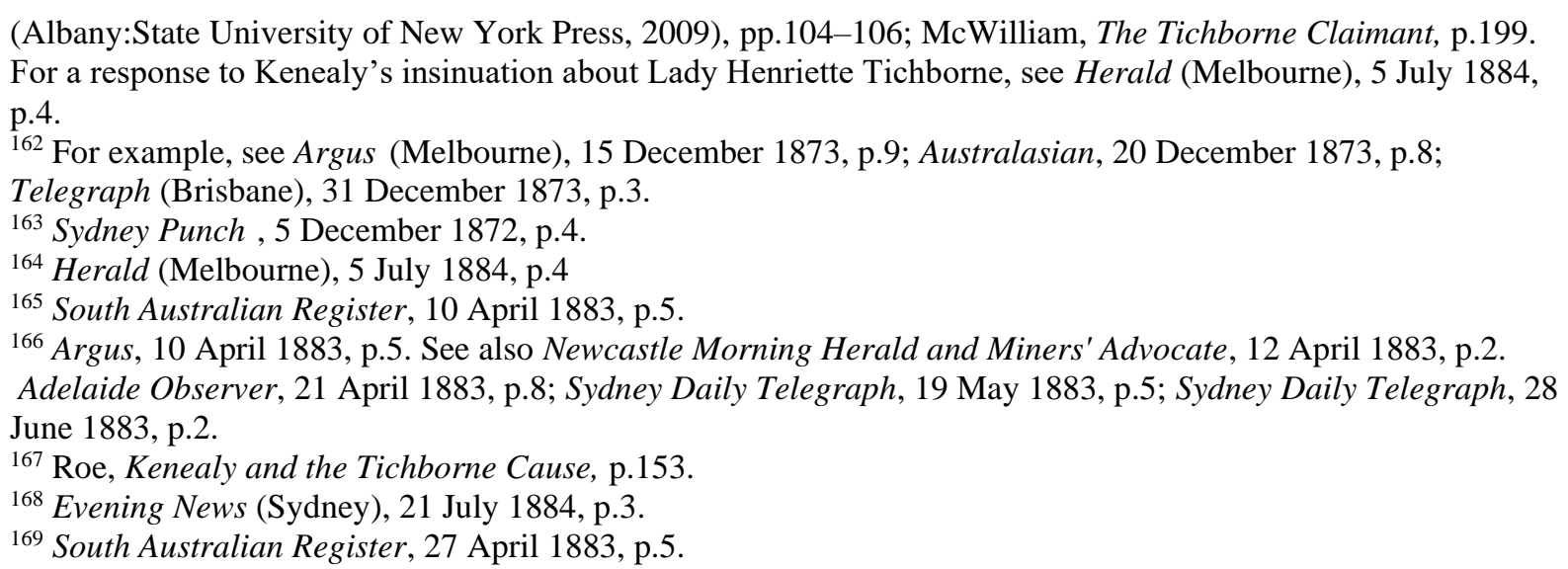


fine landed him at Darlinghurst gaol. ${ }^{170}$ Smith was scorned by the media, but, as the Sydney Morning Herald pointed out, the 'crowded state' of the courtrooms at his numerous subsequent court appearances showed that his efforts to bring about 'Tichborne mania in this colony' had succeeded, if only transiently. ${ }^{171}$

As this chapter has found, discussions about the Madeleine Smith and Tichborne Claimant cases in colonial Australian newspapers were strongly tied to ideas about femininity and masculinity. Smith's youth and elegance and the Claimant's size and manner made them readily identifiable to observers, and interest in their appearance and sexuality showed how newspapers served as mediums for shaming and objectifying purported criminals. Although hitherto unacknowledged by existing scholarship, both cases ignited gendered debates in Australia that variously resembled and deviated from those in metropolitan Britain.

As in Britain, fixation with Smith's appearance was a recurring theme in Australian newspapers, and the case instilled colonial writers, including Caroline Harper Dexter and Ellen Elizabeth Ellis, to weigh in on its details from stoutly different feminist perspectives. Fixation with the Claimant's manner and appearance in both Britain and Australia stemmed from the way he contributed to stereotypes of white Australian men as uncouth, vulgar, happy-go-lucky misfits, which some newspapers found to be endearing. Just as newspapers decried the Victorian British public's perverse fascination with crime and criminals, some also expressed fascination in the salacious nature of the two cases. As their bodies became the focal points of their respective cases, both Smith and the Claimant found favour among male groups, including Smith's numerous suitors, those who debated the corruption of women's education in Britain, and those who supported the Tichborne movement in Britain and Australia. As Chapter Four will explore, the growth of 'Tichbornism' in Australia and concerns about metropolitan criminals like Smith perverting the colonies were also strongly couched in class-conscious rhetoric.

\footnotetext{
${ }^{170}$ Evening News (Sydney), 21 July 1884, p.3.
}

${ }^{171}$ SMH, 12 December 1883, p.11. 


\section{Chapter Four: Class}

Intertwined with race, gender, and identity, the concept of class has been defined as a system for organising society according to socioeconomic status, the 'apprehension of difference and sameness', 'the ownership of capital', and divisions between 'us' and 'them'. ${ }^{1}$ Despite its centrality to studies of Victorian British history, the role of class in Australian history has been understudied, downplayed, and often abandoned in historical analysis. ${ }^{2}$ Class played an imperative role in the expansion of the British Empire. Born out of capitalist ideals, as Ann Laura Stoler notes, colonialism was not simply a 'secure bourgeois project'; 'it was not only about the 'importation of middle-class sensibilities to the colonies, but about the making of them'. ${ }^{3}$ Debate over class and 'respectability', and their associations with criminality, infused British coverage of both the Smith and Tichborne cases. This chapter analyses how those class debates were manifested in an Australian context by delving into historical attitudes toward Australia's convict past in Smith's case, as well as examining local political and populist movements connected to the Tichborne case. The chapter finds that both cases exemplified a growing class consciousness in Australia that was rooted in the growth of Australian radicalism (in the Tichborne case) and concerns about wealthy ex-criminals migrating from Britain (in Smith's case).

\section{Madeleine Smith}

Madeleine Smith's purported presence in Australia contributed to mounting debate over how the nation was developing a reputation as a retreat for unwanted Britons. British penal transportation to Australia was in its decline by the early 1860 s but the continuation of transportation to Western Australia, the nation's last remaining convict establishment, was the subject of significant contention. Whereas those who supported transportation saw it as a means of exile, rehabilitation beyond the crowded confines of Britain's metropolitan prisons, and an

\footnotetext{
${ }^{1}$ Henry Paternoster, Reimagining Class in Australia: Marxism, Populism and Social Science (Cham: Palgrave Macmillan, 2017), pp.266-267.

${ }^{2}$ See Henry Paternoster, 'Questioning the Legacy of Class Structure in Australian History: An Australian “Historical” Class Analysis?', Labour History, no. 111, 2016, pp.99-120.

${ }^{3}$ Ann Laura Stoler, 'Cultivating bourgeois bodies and racial selves', in Catherine Hall (ed.), Cultures of Empire (New York: Routledge, 2000), p.90.
} 
opportunity to begin a new life in the empire, its colonial critics deplored it as a kind of social, political, and moral contamination. ${ }^{4}$ On the issue of Western Australia, anti-transportation petitions in the early 1860s came from colonists across New South Wales, Victoria, South Australia, Tasmania, and Queensland, panning the home government for 'virtually forcing upon us, for their own protections, a class of criminals with whom they, with all the experience of modern civilization, are powerless to contend against' 5 'Many of the more respectable parts of Australian society', as Martin Wiener points out, blamed incidents of violence in the colonies on the 'scum' of the mother country, 'the criminal classes drawn to the lawlessness on the fringes of civilisation' ${ }^{6}$

Before rumours that Smith had retreated to Australia escalated, many Australian newspapers took aim at the troubling growth of crime in Britain and the Victorian public's fascination with it. The Age was among the first to report on the Smith case and echoed the Times's disbelief that 'a young lady of only 21, virtuously bred, and highly accomplished, should destroy her lover' ${ }^{7}$ It took a strong interest in the case thereafter, publishing a day-today account of the trial, advertising reports of the trial and portraits of Smith, and pasting excerpts from Scottish papers, including the Alloa Advertiser, Caledonian Mercury, Glasgow Courier, Glasgow Herald, Dundee Advertiser, Aberdeen Herald, and John O'Groat Journal throughout its coverage. The Age's owners, brothers Ebenezer and David Syme, indeed hailed from Scotland, and the latter became known for his staunch protectionism during his tenure as editor for the next fifty years. ${ }^{8}$ The paper's nationalism and working-class sympathies shone through in its coverage of the Smith case as it stridently condemned the perceived growth of crime in Britain and its depraving impact on Australia. ${ }^{9}$ Concerns about a 'morbid passion for the horrible' in England, letters to the editor worried over sensations like Smith 'contaminating'

\footnotetext{
${ }^{4}$ Philip Harling, 'The Trouble with Convicts: From Transportation to Penal Servitude, 1840-67', Journal of British Studies, Vol. 53, No. 1, 2014, p.109; Hilary M. Carey, Empire of Hell: Religion and the Campaign to End Convict Transportation in the British Empire, 1788-1875 (Cambridge: Cambridge University Press, 2019), pp.300-301.

${ }_{5}^{5}$ Carey, Empire of Hell, p.301.

${ }^{6}$ Martin J. Wiener, An Empire on Trial: Race, Murder, and Justice under British Rule, 1870-1935 (Cambridge: Cambridge University Press, 2009), p.48.

${ }^{7}$ Age, 8 June 1857, p.6. See also The Times, 4 April 1857, p.10.

${ }^{8}$ Ambrose Pratt, David Syme: The Father of Protection in Australia (London and Melbourne: Ward Lock \& Co Ltd., 1908), p.115.

${ }^{9}$ C. E. Sayers, 'Syme, Ebenezer (1825-1860)', Australian Dictionary of Biography, National Centre of Biography, Australian National University, http://adb.anu.edu.au/biography/syme-ebenezer-4680/text7743, published first in hardcopy 1976, accessed 7 December 2020.
} 
readers, and expressions of outrage over public worshipping of criminals were also shared by its companion, the Melbourne Leader. ${ }^{10}$

Fears of Britain's criminality perverting the colonies were not limited to readers of the Age and Leader. Goldfield town papers, such as the Bendigo Advertiser, the Star in Ballarat, and Castlemaine's Mount Alexander Mail similarly questioned the excitement that Smith's case had generated and expressed fear that colonial parallels of 'sensual excess', mental suffering, destitution, and 'self-murder' would escalate. ${ }^{11}$ Newspapers in Sydney also shared feelings of bewilderment over how such 'morbid taste for excitement' was 'so peculiar to Englishmen' ${ }^{12}$ For these papers, the question of Smith's guilt was not the only issue. In fact, few weighed in on the matter. Rather, it was the public's bizarre fascination and sympathy with convicted criminals like Smith that was seen as most troubling.

English-born Australian journalist, Edward Wilson, was a staunch critic of transportation to Western Australia, particularly from 1863-64 when a Royal Commission was created to seek possible sites for further convict colonies. ${ }^{13}$ Wilson accused Britain of turning Australia into a 'cesspool' for criminals, bemoaned how Victoria had become inundated with 'ruffians' (or former convicts), and proposed that, 'for every six hundred petty larceny rogues sent out from England', he would 'send in return six hundred burglars and murderers from Victoria'. ${ }^{14}$ Condemning Wilson's remarks, the Geelong Advertiser pointed out that public sympathy for criminals like the 'popular' Smith and Jessie M'Lachlan, found guilty of murdering a servant in Glasgow in 1862, suggested that not all colonists, including Wilson himself and even the 'religious, moral, and canny' Scots, saw former convicted criminals as wholly undesirable, especially when regarded as individuals as opposed to an anonymous mass. $^{15}$

The stereotyping of Australia as a nation of ex-convicts and ex-criminals had long been advanced across British media platforms throughout the century, and was tied to persistent debates in the metropole over the functions of penal transportation: whether it reformed,

\footnotetext{
${ }^{10}$ Age, 13 November 1857, p.4; 21 November 1857, p.6; 9 December 1857, p.6.

${ }^{11}$ Bendigo Advertiser, 18 January 1858, p.2. The Bendigo Advertiser refers to the murder of Sophia Lewis in Melbourne in 1857 as one example. See also Star (Ballarat), 17 July 1860, p.2; Mount Alexander Mail, 18 October 1857, p.3.

${ }^{12}$ Bell's Life in Sydney and Sporting Chronicle, 12 September 1857, p.2. See also SMH, 8 September 1857 , p.2.

${ }^{13}$ Geoffrey Serle, 'Wilson, Edward (1813-1878)', Australian Dictionary of Biography, National Centre of Biography, Australian National University, http://adb.anu.edu.au/biography/wilson-edward-4866/text8131, published first in hardcopy 1976, accessed 11 January 2021.

${ }^{14}$ Geelong Advertiser, 23 July 1864, p.2.

15 Ibid.
} 
rehabilitated, or merely rid Britain of criminals. ${ }^{16}$ Such stereotypes featured in broadsides, memoirs, travel narratives, journalism, and in literature, most notably in the work of Charles Dickens, where characters like Wilkins Micawber from David Copperfield (1850) and Abel Magwitch from Great Expectations (1861) settle in the colony and lead relatively more prosperous lives. ${ }^{17}$ As Christopher Kent suggests in an analysis on the Tichborne case, Australia was commonly perceived as a 'dumping ground' for not only convicts, but also 'unsatisfactory characters in Victorian novels'. ${ }^{18}$ Further 1864 reports positing that Smith and her husband, George Wardle, had emigrated and were 'doing well' in Australia typified the notion that Australia 'seems to be the receptacle of all sorts of people', as the Leader noted. ${ }^{19}$ Writing in 1866, the Age accepted the convict label as accurate and cited another report that Smith had recently married a wealthy sheep farmer in Australia. ${ }^{20}$ The Melbourne Punch found humour in the idea that Smith had opted for a more tranquil - if uneventful-life in the colony, and considered it a 'terrible disappointment to the sentimental' that she had not died of a broken heart but was 'alive and well somewhere in Australia'. ${ }^{21}$ Reported sightings of Smith once again cropped up throughout the 1880 s, leading to a new narrative that her family had sent her out to the colonies shortly after her trial, that she had married Tudor Hora, a doctor, and that she had lived in secrecy in Perth, Melbourne, and then again in Perth after her separation from Hora until her apparent death on 29 September $1893 .^{22}$ Other accounts suggest she returned to England after her separation from Hora and met Wardle before returning to Melbourne following his death in $1892 .^{23}$

It was not coincidental that stories of Smith in Australia resurfaced in the early 1890s after Salvation Army General William Booth proposed a scheme to build a transnational colonial network. In his 1890 book, In Darkest England and the Way Out, Booth sought to cultivate what he saw as unproductive lands in Australia, New Zealand, South Africa, Canada, and India, and create a home for the 'thieves, harlots, paupers, drunkards, prodigals', and

\footnotetext{
${ }^{16}$ Dorice Williams Elliot, Transported to Botany Bay: Class, National Identity, and the Literary Figure of the Australian Convict (Athens, OH: Ohio University Press, 2019), p.11.

${ }^{17}$ Ibid, p.30.

${ }^{18}$ Christopher Kent, 'Victorian Self-Making, or Self-Unmaking? The Tichborne Claimant Revisited', Victorian Review, Vol. 17, no. 1, 1991, p.25.

${ }^{19}$ Leader (Melbourne), 10 September 1864, p.5.

${ }^{20}$ Age, 12 April 1866, p.4.

${ }^{21}$ Melbourne Punch, 22 September 1864, p.2.

${ }^{22}$ Daily News (Perth), 16 December 1893, p.3

${ }^{23}$ Age, 30 December 1893, p.11; Australasian, 19 May 1894, p.22.
} 
'destitute multitudes' of Britain's 'great towns and cities' where they could be put to work. ${ }^{24}$ His colonial critics derided the scheme as merely a means of transplanting Britain's troublesome populations onto the colonies. ${ }^{25}$ The National Advocate, a nationalist newspaper from Bathurst, criticised Booth for proposing to 'flood' the nation 'with pauper and criminal labor [sic]', and noted that one Madeleine Smith in Australia was enough, let alone a multitude more Madeleine Smiths receiving preference and being the first in the continent. ${ }^{26}$

The notion that Britain's 'undesirable' classes and people of 'doubtful respectability' were given opportunities for a new beginning in Australia was often met with concern among other colonists. As Dorice Williams Elliot notes, much of the 'new', post-transportation Australia wanted its identity to be 'free of the taint of convictism' while also functioning as a place of redemption and more fluid class mobility for those who had 'failed to support their class position' in England. ${ }^{27}$ The continued influx of ex-criminals like Smith-whether fictional or not-reminded fearful Australians that those leading prosperous and obscure lives in the colony could also be concealing dark and storied backgrounds 'at home'. 'The problem' in colonial cities, Kirsten McKenzie suggests, was that 'people could be other than what they seemed'. ${ }^{28}$ Hearsay, gossip, and rumour were inherently tied to reputation, and reported sightings of Smith throughout the late nineteenth century showed that those heeding the rumours held her up as a figure of social significance, infamy, and disrepute despite her best attempts to transgress such labels. Her less conspicuous sightings, such as her purported criminal association with bushranger Frank Gardiner, reinforced concerned colonists' beliefs that colonial life was not always the kind of rehabilitative project that figures like Booth espoused it to be.

Some newspapers found comfort in the idea that, despite fears of colonists giving celebrated criminals unneeded attention, a case like Madeleine Smith's was still a rarity in the colonies. 'Such instances of horrible depravity', the Bendigo Advertiser wrote, 'while they are not unfrequent [sic] in the older countries, are happily but seldom heard of in the Australias' ${ }^{29}$ Indeed, upon hearing of the murder of Henry Kinder in Sydney in 1866, the Sydney Punch joked

\footnotetext{
${ }^{24}$ William Booth, In Darkest England and the Way Out (London: International Headquarters of the Salvation Army, 1890), p.93.

${ }^{25}$ Barbara Arneil, Domestic Colonies: The Turn Inward to Colony (Oxford: Oxford University Press, 2017), p.60.

${ }^{26}$ National Advocate (Bathurst), 19 February 1891, p.3.

${ }^{27}$ Elliot, Transported to Botany Bay, pp.194-195.

${ }^{28}$ Kirsten McKenzie, Scandal in the Colonies (Melbourne: Melbourne University Press, 2005), p.1.

${ }^{29}$ Bendigo Advertiser, 15 March 1858, p.2.
} 
that Australia had reached 'enlightenment' as a colony because it finally had its own 'sensation' case like that of Smith's. ${ }^{30}$ The image of Australia as being less susceptible to violent domestic crimes than Britain made anti-transportation, anti-Booth, and nationalist rhetoric all the more fervent.

'Ne'er-do-weels', a colloquial term used in late nineteenth-century Britain to describe a lazy or irresponsible person, was applied in a colonial context to describe 'dysfunctional' young male migrants who tended to hail from wealthy families, who were sent to the colonies to improve themselves, and who threatened the 'natural order' of colonists' 'ideal' societies. ${ }^{31}$ The monied 'ne'er-do-weel' challenged concepts of colonial manhood defined by hard work and determination rather than simply living off existing fortunes. ${ }^{32}$ While the gendered term was not used to describe Smith, its wide usage in Australia and New Zealand shows that many colonists were less than receptive to migrants seen as detrimental to social stability in the colonies, whether they were 'unproductive snobs' - as New Zealand settler Charles Hursthouse called them-or lowly ex-convicts. ${ }^{33}$ Smith's presence, along with her numerous suitors, only added to such feelings of resentment toward the types of British migrants coming to Australasia.

Australian newspapers used the Smith case to express concern about crime being committed by the wealthy classes in Britain, and not just the urban poor. 'No longer are the culprits found secreting on a lonely highway', the Northern Times wrote, the 'ranks of villainy' were now occupied by those as respectable as Smith. ${ }^{34}$ Newspaper reports across Australia and New Zealand noted that Smith hailed from a 'respectable' background to add to their sensationalised headings. Whether it was out of agreement with the working-class Glasgow Sentinel's argument that the law favoured Smith because of her respectable social position —or out of an attempt to emphasise how prominent the case had become in Glasgow-colonial newspapers also pointed out that Smith's family had hired one of Scotland's most esteemed

\footnotetext{
${ }^{30}$ Sydney Punch, 6 January 1866, p.2.

${ }^{31}$ Jennifer Kain, 'The Ne'er-do-well: Representing the Dysfunctional Migrant Mind, New Zealand 1850-1910', Studies in the Literary Imagination, Vol. 48, no. 1, 2015, pp.75-92. See also Miles Fairburn, The Ideal Society and its Enemies: The Foundations of Modern New Zealand Society 1850-1900 (Auckland: Auckland University Press, 1989), p.73.

${ }^{32}$ Catherine Hall, Civilising Subjects: Metropole and Colony in the English Imagination, 1830-1867

(Cambridge: Polity Press, 2002), p.27.

${ }^{33}$ Quoted in Kain, 'The Ne'er-do-well', pp.80-81.

${ }^{34}$ Northern Times, 12 September 1857, p.2.
} 
legal minds in John Inglis. Some also published the names of the many Glasgow merchants and friends of the family that assisted in paying for Smith's defence. ${ }^{35}$

Reference to the social position of alleged criminals was common practice in the colonial newspaper press. As well as the severity of the crime and whether the accused offender's life was at stake, the 'newsworthiness' of a local criminal case was also determined by the 'status' of the victim and the alleged offender. ${ }^{36}$ As McKenzie points out, scandals threatened the social positions of men and women in starkly different ways and, in doing so, highlighted the complexities of class and respectability in colonial settings. Whereas 'good name, fair fame, and credit' were closely tied to white male definitions of class, and often expressed in a commercial or political context, class position for white women was 'inseparable from sexuality'. ${ }^{37}$ Smith's case not only challenged the concepts of marital legitimacy and chastity that often defined class position for colonial women, it also threatened to disrupt the supposed sanctity of the colonial home. $^{38}$

Some commentators sympathised with Smith and villainised L'Angelier based on the pair's distinct social positions. Despite the Age's comments on the public's unnecessary fascination with Smith, the Melbourne Leader was vocal about its predispositions toward her innocence. The newspaper concurred with Smith's defence attorney, John Inglis, and deemed it unlikely that Smith murdered L'Angelier because she lacked a motive, and more likely that L'Angelier committed suicide based on his history of arsenic use. 'The more the evidence is scrutinised', it wrote, 'the stronger becomes the probability of innocence'. ${ }^{39}$ Such sentiments were shared by David Field Rennie, the Surgeon to the convict establishment in Western Australia and Assistant Surgeon in the Ordinance Medical Department at the Licentiate Royal College of Surgeons of Edinburgh. Rennie, who originally hailed from Scotland, analysed the circumstances of the Smith case in a series of articles for the Perth Gazette and Independent Journal of Politics and News over November and December 1857. He concluded that L'Angelier was 'a man of very impaired constitution' and suffered from chronic arsenic poisoning as a result of his addiction to the substance prior to meeting Smith in 1855 . The

\footnotetext{
${ }^{35}$ For example, see Northern Times, 12 September 1857, p.4; Age, 19 September 1857, p.3. For more on the Glasgow Sentinel, see Eleanor Gordon and Gwyneth Nair, Murder and Morality in Victorian Britain: The Story of Madeleine Smith (Manchester: Manchester University Press, 2010), p.143.

${ }^{36}$ Michael Sturma, 'Crime News in Colonial New South Wales', Media Information Australia, Vol. 32, no. 1, 1984, p.8.

${ }^{37}$ McKenzie, Scandal in the Colonies. p.183.

${ }^{38}$ Ibid, pp.183-184.

${ }^{39}$ Quoted in Age, 9 December 1857, p.6.
} 
delayed onset of L'Angelier's symptoms, along with the lack of evidence to implicate Smith with his death, rendered the case a matter of either suicide or poisoning by someone other than Smith, in Rennie's view. ${ }^{40}$ Although regarding his medical analysis as unbiased, Rennie overtly contrasted Smith as a 'handsome', 'accomplished', 'fashionable', and 'respectable' young woman with L'Angelier as a 'worthless' man 'of inferior station' ${ }^{41}$

The derogatory 'ne'er-do-weel' label was occasionally applied to L'Angelier, but the discrepancy between his class position and that of Smith's was generally less commented onor more subtly discussed - in the Australian press than in Britain. ${ }^{42}$ Nonetheless, just as readers of colonial newspapers weighed up the benefits of James Smith's system of seclusion to 'preserve his flower Madeline [sic] from contamination' (as discussed in Chapter Three), disdain for L'Angelier's conduct also became a prominent feature in coverage of the case, as it had been in Britain. ${ }^{43}$ Amidst news of the trial's proceedings, Australian newspapers-despite lacking strong convictions toward the verdict-similarly chastised L'Angelier through pejorative characterisations of him as a 'little flighty Frenchman';4 'the little guppy from Jersey'; ${ }^{45}$ a 'very vain worthless young man'; ${ }^{46}$ and an 'unmanly creature' ${ }^{47}$ Commenting on the trial more than thirty years later, New Zealand's Daily Telegraph even went so far as to suggest that 'nobody doubted' Smith's guilt, 'but the general feeling was one of relief when she was acquitted, especially as it came out in the trial that the love of her lover was mere French lust'. ${ }^{48}$ Not all remarks about L'Angelier's character were as scathing, but that he was 'of French extraction' and a 'native of the French-inhabited island of Jersey' appeared to be a given. ${ }^{49}$ Derision of his conduct did not necessarily lend itself to the view that Smith was innocent, but it did add further complications to a case already rife with scandal, speculation, and polarising opinions.

\footnotetext{
${ }^{40}$ Perth Gazette and Independent Journal of Politics and News, 27 November 1857, pp.4, 5; 4 December 1857 , p.4; 11 December 1857 , p.4.

${ }^{41}$ Ibid, 11 December 1857, p.4.

${ }^{42}$ For example, see John Rowland, A Century of Murder (London: Home and Van Thal, 1950), p.37.

${ }^{43}$ Quoted in Argus, 7 October 1857, p.6; Colonist, 27 October 1857, p.3.

${ }^{44}$ Star (Ballarat), 7 September 1857, p.3. See also OMA, 8 September 1857, p.3;

Bendigo Advertiser, 8 September 1857, p.3.

${ }^{45}$ Ibid.

${ }^{46}$ South Australian Register, 10 September 1857, p.2. See also Portland Guardian and Normanby General Advertiser, 7 September 1857, p.2.

${ }^{47}$ Perth Gazette and Independent Journal of Politics and News, 27 November 1857, p.4. See also Star (Ballarat), 7 September 1857, p.3; OMA, 8 September 1857, p.3; Bendigo Advertiser, 8 September 1857, p.3.

${ }^{48}$ Daily Telegraph (Napier), 27 December 1893, p.2.

${ }^{49}$ Age, 9 December 1857, p.6.
} 
Occasionally, some larger newspapers, such as the Argus, Age, and the Sydney Morning Herald, copied articles from British papers that treated L'Angelier with sympathy, including accounts in the Liverpool Albion, the Glasgow Herald, and the Dundee Advertiser. Those who defended L'Angelier tended not to use stereotypes and in some cases called them out for their inaccuracy. The Liverpool Albion pointed out that Smith's letters showed that L'Angelier was capable of remorse whereas Smith was not; ${ }^{50}$ the Glasgow Herald cited L'Angelier's 'exemplary, amiable, and studious course of life' and favourable opinion among those who knew him ${ }^{51}$ and the Dundee Advertiser gave voice to an article written by William Laird, L'Angelier's employer in Dundee, which described him as being void of a 'single stain' on his character 'unless poverty be a crime'. ${ }^{52}$ Although New Zealand's Colonist also published the Liverpool Albion's account, the Otago Witness remained the only newspaper directly to challenge generalisations of L'Angelier by subtly pointing out that he 'did not belong to France, but was a native of Jersey, and consequently a British subject', at least until news of the trial and Smith's letters were published. ${ }^{53}$

Smith's purported presence in the colonies figured into contemporary concerns about the influx of ex-criminals and 'unproductive' migrants at a time when Australia was at odds in shifting away from its convict identity. The class consciousness of Australian newspapers was less obvious in their coverage of the Smith case when compared to their British counterparts. However, references to Smith's social status and respectability; newspapers' wider concerns about the growth of crime among Britain's wealthy classes; and occasional expressions of sympathy toward L'Angelier's lower social position show that class consciousness still played a significant role in coverage of the case, even if it was more tied to extrinsic denouncements of rigid class dynamics in Britain than self-reflective discussions about class in Australia. Those self-reflective discussions were more visible-and more politicised-in coverage of the Tichborne case, as the following section finds.

\footnotetext{
${ }^{50}$ Quoted in Argus, 7 October 1857, p.6; SMH, 12 October 1857, p.5; South Australian Register, 10 November 1857, p.3.

${ }^{51}$ Quoted in Age, 21 October 1857, p.6.

${ }^{52}$ Ibid, 16 October 1857, p.5.

${ }^{53}$ Otago Witness, 1 August 1857, p.6. See also Colonist, 27 October 1857, p.3.
} 


\section{The Tichborne Claimant}

Max Everest-Phillips argues that the Claimant's actions 'strengthened Australia's emerging sense of national distinctiveness around equal opportunity, in contrast to entrenched inequalities at the centre of the British Empire', and 'reinforced a self-image of classless 'happy go lucky' pioneers seizing any opportunity offered'. ${ }^{54}$ Indeed, at least during the Tichborne trials and the height of the Tichborne movement in Britain, 'Tichbornism' in an Australian context was less of a mass mobilisation of working-class communities than an investment in the 'underdog' idea of one colonial man pitted against English respectability. Although the issue of class was less pronounced in Australian coverage of the Tichborne case when compared to Britain, it nonetheless influenced aspects of 'Tichbornism' in significant albeit often subtle and political ways.

As in Britain, and much like the Madeleine Smith case, Australian coverage of the Tichborne case regularly referred to the social positions of the Claimant's supporters and detractors. Many newspapers appeared class-conscious in detailing the case, even if supporters in Australia were not always concerned with dismantling underlying class structures as 'Tichbornites' in Britain were. Newspapers that were critical of the Claimant were also critical of the populist movement that he helped generate. The Age was dismissive of the radicalism aroused by the Tichborne movement in England and Edward Kenealy's election to the House of Commons, writing 'the sympathy shown for the Claimant was not prompted by any strong belief in the justice of his cause, but sprang from a chivalrous disposition to help the weak against the powerful' ${ }^{55}$ The paper also blamed the Claimant's long association with Australia's lower classes for obscuring his early mental training. ${ }^{56}$ The Herald cited the longevity of the case when it took gibes at England's aristocracy and the Crown for not quelling the movement sooner. It wrote at the end of the civil trial that 'in the first place, he (the Claimant) has had all the prejudices and power of the aristocracy of England arrayed against him; and then the Crown, with its unlimited resources, has not spared money nor exertions to "pot" him as a criminal'.57 Increasingly dismissive of the Claimant following the civil trial, the Sydney Morning Herald often made references to the class composition of Tichbornites and the breaking out of 'Orton

\footnotetext{
${ }^{54}$ Max Everest-Phillips, 'The 1871 'Tichborne Claimant' medal and the forging of Australia's identity', Journal of the Numismatic Association of Australia, Vol. 24, 2013, p.3.

${ }^{55}$ Age, 10 April 1875, p.4.

${ }^{56}$ Age, 1 August 1871, p.2.

${ }^{57}$ Herald (Melbourne), 13 April 1872, p.2.
} 
fever' confined to England's 'lower classes'. ${ }^{58}$ The newspaper asked, 'could the sympathies of the labouring classes really go with a man who, if one of themselves, was a perjured impostor, and, if not an impostor, a disgrace not merely to the rank he wished to assume, but to any rank and any parentage?'59

The answer to the Sydney Morning Herald's question in part-or at least tangibly-lay in the sale of the 'Tichborne Bonds' in Britain and Australia. During the civil trial, each $£ 100$ bond was typically sold at a discounted rate of $£ 65$ or less, allowing pundits to bet on the probability of the Claimant's identity (and the trial's outcome); the odds of the Claimant's genuineness were thus reflected in the bond's price. ${ }^{60}$ Australian newspapers keenly tracked the value of the bonds throughout the civil trial. By January 1872, the Evening News and Empire reported the value of a Tichborne bond to have to dropped to $£ 25 .{ }^{61}$ Following the trial, bonds were reportedly sold in Melbourne for as little as $8 \mathrm{~s}, 4 \mathrm{~d}$. 'This rate must surely be more as a curiosity speculation than a market investment', the Age wrote. $^{62}$ In the same way that newspapers commented on how the poor and working classes in Britain only cheered for Madeleine Smith because they had bet on the trial's outcome, the Leader noted that the bond's market value was 'measured more by the faculty of faith in the glorious uncertainty of the law than by any judgment... on the Claimant's right to a verdict'. ${ }^{63}$ According to Woodruff, only $£ 40,000$ of the targeted $£ 100,000$ were raised. ${ }^{64}$

Betting on the Claimant's case also took place outside of the dubious Tichborne bond scheme. Following the civil trial, the Wagga Wagga Express emphasised the vast extent to which locals had bet against the Claimant 'from the very first moment that he put forth his claim'. ${ }^{65}$ In Melbourne, the Argus regretted knowing that the 'pretensions of the impostor were supported, betted upon, and backed with pecuniary subsidies by men of substance and position', and wrote that its estimate of the 'average intelligence of society' had been lowered as a result. ${ }^{66}$ Opting for neutrality, the Sydney Morning Herald wrote that betting on the cause had been

\footnotetext{
${ }^{58}$ For example, see $S M H, 2$ June 1875, p.3.

${ }^{59} \mathrm{SMH}, 12$ October 1872 , p.7.

${ }^{60}$ Kent, 'Victorian Self-Making', p.31.

${ }^{61}$ Evening News (Sydney), 26 January 1872, p.3; Empire, 27 January 1872, p.4. Other newspapers incorrectly heeded the Wagga Wagga Advertiser's report that the bonds had changed from £15 (instead of £65) to £25. See WWA and Riverine Reporter, 31 January 1872, p.3.

${ }^{62}$ Quoted in Empire, 13 May 1872, p.2.

${ }^{63}$ Leader (Melbourne), 27 January 1872, p.17.

${ }^{64}$ Douglas Woodruff, The Tichborne Claimant: A Victorian Mystery (London: Hollis and Carter, 1957), p.165.

${ }^{65}$ WWE and Murrumbidgee District Advertiser, 10 April 1872, p.2.

${ }^{66}$ Argus, 8 April 1872, p.4
} 
'carried out to a great degree' and 'ought indeed to be punishable'. ${ }^{67}$ The newspaper expressed particular concern at how betting on the trial was 'an auxiliary against which no guard can be set up' and how it highlighted the wider societal problem of gambling more generally. ${ }^{68}$ Gambling transcended classes in mid-late nineteenth-century Britain, but mass betting-more grounded in knowledge and judgement, and less risky than irrational forms of gambling — was especially popular among the working classes. ${ }^{69}$ Similar trends occurred in Australia. ${ }^{70}$ Australian newspapers' negative responses to the betting in the Claimant's favour were also consistent with responses in Britain, where many newspapers were so alarmed by the widespread betting that some sporting journals, including Bell's Life in London, cancelled all bets on a victory for either side of the Tichborne conundrum. ${ }^{71}$

Australian literary figures also capitalised on the Tichborne case and associated it with Australia's ex-convict identity, as newspapers did with Madeleine Smith's case. Writer Marcus Clarke drew on the contradictory reactions to the case in the metropole when he penned the novel, His Natural Life, in serialised form from 1870 to 1872 in The Australian Journal (where he also served as editor). Later novelised as For the Term of His Natural Life in 1874, the story centres on Rufus Dawes, a British convict transported to Van Diemen's Land for a murder he did not commit, who is defrauded of his identity as the inheritor to an estate in England by a fellow convict. ${ }^{72}$ The novel's examination of convict life in Australia is buttressed by its foray into themes of identity, illegitimacy, and anxieties about the disruptive homecoming of exconvicts that were contemporaneous with the ongoing Tichborne trials. It proved to be lucrative in Britain, and echoed expressions of amusement seen in the Australian newspaper press over how Britons were quick to rally behind the Tichborne cause. As Wagner notes, 'the imperialist centre is indicted [in the novel] for an almost absurd gullibility as well as an incompetent judicial system' ${ }^{73}$

\footnotetext{
${ }^{67}$ SMH, 23 August 1871, p.4.

${ }^{68}$ Ibid.

${ }^{69}$ Ross McKibbin, 'Working-Class Gambling in Britain 1880-1939', Past \& Present, no. 82, 1979, pp.172-178; Geoffrey Russell Searle, Morality and the Market in Victorian Britain (Oxford: Clarendon Press, 1998), p.232.

${ }^{70}$ See John O'Hara, A Mug's Game: A History of Gaming and Betting in Australia (Kensington: New South Wales University Press, 1988).

${ }^{71}$ Michael Roe, Kenealy and the Tichborne Cause: A Study in Mid-Victorian Populism (Melbourne: Melbourne University Press, 1974), p.53

${ }^{72}$ Marcus Clarke, For the Term of His Natural Life (London: Oxford University Press, 1957. First published in 1874).

${ }^{73}$ Tamara S. Wagner, 'The domestic novel's antipodes: false heirs and reclaimed returnees in Charlotte Yonge's My Young Alcides', Journal of Australian Studies, Vol. 35, no. 3, 2011, pp.324-325.
} 
Australian newspapers praised Clarke's novel for exposing the harsh conditions and brutal punishments that convicts faced during penal servitude under 'ferocious' British administration. ${ }^{74}$ The novel's success in Australia, Dawson suggests, stemmed from the way it addressed Australian readers' 'anxieties about the relationship between their status as colonials and their English reception as illegitimate' that had been exacerbated by the Tichborne trials. ${ }^{75}$ Sympathetic in its portrayal of the innocent Dawes and critical of his impersonator, who (akin to the Claimant) degenerates into a 'sodden, massive figure', its narrative, as many of the Australian Tichborne affidavits attempted to do, told the gritty story of a 'real', Australian 'Simon Pure' against Victorian sensationalism. ${ }^{76}$ Clarke was no stranger to the cultural allure of sensational criminal trials; his wife was none other than Marian Dunn, the actor who played Madeleine Smith in George Fawcett's 'Chamber of Horrors'. ${ }^{77}$

Further exemplifying how Australians took an interest in 'Tichbornism' from afar, copies of the Tichborne Gazette and the Englishman were advertised in various regions of the country during and following the civil and criminal trials. ${ }^{78}$ Colonial newspapers continued to publish articles about the Tichborne movement in Britain long after the criminal trial, and they closely covered Kenealy's eventual falling out with the movement in 1876. The Tichborne Gazette resumed publication after the criminal trial because the Englishman had become 'a staging point for Kenealy's own messianic program', as Thomas notes, and its critics, including the Wagga Wagga Advertiser, felt that too much attention was placed on its author, Kenealy, and not enough on the Claimant's cause. ${ }^{79}$ Some Australian papers, such as the Daily Northern Argus and Sydney's Freeman's Journal, voiced their outrage at how Kenealy had profited from the Tichborne cause yet 'could not give the crumbs from his table to poor Tichborne's wife and children' ${ }^{80}$

The Tichborne case and its association with British radicalism were contemporaneous with Australia's own form of nascent radicalism. As a challenge to both liberalism and

\footnotetext{
${ }^{74}$ Australasian, 16 May 1874, p.7. See also Ballarat Star, 20 May 1874, p.3; SMH, 21 May 1874, p.6; Bendigo Advertiser, 30 May 1874, p.2.

${ }^{75}$ Cassie Dawson, "“The Slaughterman of Wagga Wagga”, Imposture, National Identity, and the Tichborne Affair', Australian Literary Studies, Vol. 21, no. 4, 2004, p.8.

76 Wagner, 'The domestic novel's antipodes', p.325.

${ }^{77}$ Maggie Blackburn, 'Entertaining Prospects: Garrison and Gold Field Theatre in 19th-Century New Zealand circa 1850-1870', MA Thesis, Victoria University of Wellington, 2021, p.44.

${ }^{78}$ For example, see Ballarat Courier, 29 July 1872, p.4; Evening Journal (Adelaide), 28 November 1872, p.3; South Australian Register, 28 November 1872, pp.4-5; Weekly Examiner (Launceston), 8 August 1874, p.11.

${ }^{79}$ David Wayne Thomas, Cultivating Victorians: Liberal Culture and the Aesthetic (Philadelphia: University of Pennsylvania Press, 2004), p.93; WWA and Riverine Reporter, 8 July 1874, p.4.

${ }^{80}$ Daily Northern Argus, 9 November 1875, p.2; Freeman's Journal, 11 December 1875, p.5.
} 
conservatism - and a response to the bourgeoise's access to political power-radicalism emerged as a populist movement in Australia between the $1840 \mathrm{~s}$ and $1860 \mathrm{~s} .{ }^{81} \mathrm{R}$. W. Connell and T. H. Irving, the authors of the seminal text on class formation in Australia (Class Structure in Australian History, first published in 1980), point out that 'although radicals were aware of the formation of the working class in Britain, they refused to discuss colonial politics in class terms' and 'they discriminated between 'the people', whose interests were reconcilable by good government, and 'the classes', who selfishly oppressed the people through their control of the state ('class legislation')' ${ }^{82}$ Unlike British newspapers, Australian newspapers' attitudes toward the Tichborne case during the trials did not always reflect their social or political positions.

While most newspapers resorted to strident opposition toward the Claimant's cause, as British newspapers did, those that supported the Claimant tended to stem from wide-ranging social backgrounds, and many carried liberal views. For example, the Wallaroo Times and the Tumut and Adelong Times were liberal, politically non-partisan mining journals, ${ }^{83}$ the Gundagai Times was dismissive of 'petty rivalries and injurious class distinctions'; 84 the Riverine Grazier was liberal-conservative and targeted toward pastoral and agricultural matters, ${ }^{85}$ the Telegraph, St Kilda, Prahran and South Yarra Guardian had its origins in British Liberal politics; ${ }^{86}$ and the Hobart Mercury's editor during the height of the case, James Simpson, was known for his broad, independent, and liberal opinions. ${ }^{87}$ In the view of the Illustrated Sydney News, up-country journals like the Wangaratta Star were to blame for heeding questionable affidavits that supported the Claimant. ${ }^{88}$ But while newspapers from towns said to be connected to the Claimant's past regularly reported on the case, partisanship toward (or against) the case was not always geographically or politically divided.

Although not ardent supporters, the Argus, the Sydney Morning Herald, and the Geelong Advertiser were occasional sympathisers with the Claimant. ${ }^{89}$ As Victoria's first newspaper, the Geelong Advertiser was progressive in its ideals and borrowed rhetoric from radical reformist

\footnotetext{
${ }^{81}$ R. W. Connell and T. H. Irving, Class Structure in Australian History: Documents, Narrative and Argument (Melbourne: Longman Cheshire, 1986. First published in 1980), pp.119-120.

${ }^{82}$ Connell and Irving, Class Structure in Australian History, p.121.

${ }^{83}$ Wallaroo Times and Mining Journal, 1 February 1865, p.2; Rod Kirkpatrick, Country Conscience: A History of the New South Wales Provincial Press, 1841-1995 (Canberra City: Infinite Harvest Publishing Pty Ltd, 2000), p.28.

${ }^{84}$ Gundagai Times and Tumut, Adelong and Murrumbidgee District Advertiser, 18 January 1868, p.2.

${ }^{85}$ Riverine Grazier, 29 October 1873, p.2.

86 The paper was founded by British Liberal politician, Howard Spensley.

${ }^{87}$ James Fenton, A History of Tasmania (Hobart: J. Walch and Sons; Launceston: Walch Brothers and Birchall, 1884), p.433.

${ }^{88}$ Illustrated Sydney News and New South Wales Agriculturalist and Grazier, 29 August 1873, p.2.

${ }^{89}$ Roe, Kenealy and the Tichborne Cause, p.146.
} 
newspapers in Britain when employing language of 'the people' and 'the public' and espousing the press to be 'the mighty engine for the promulgation of Truth'. ${ }^{90}$ The newspaper often abstained from giving its own opinions on the case, but its fondness for the Claimant's cause was more implicitly signalled in the way it gave voice to evidence and other newspaper articles that favoured the Claimant. Affidavits did not always generate support for the Claimant, but they did amount to a vested interest in the case. For example, the question as to whether the imprisonment of the Claimant was justifiable was a hot topic of debate for the Geelong Young Men's Association toward the end of the criminal trial, who largely concurred. ${ }^{91}$

The Argus and the Sydney Morning Herald were both large, metropolitan conservative newspapers whose proprietors at the height of the Tichborne case were the first to enter into negotiations to form an Associated Press and an agreement with Reuters to transmit telegraphic news items to Australia. ${ }^{92}$ The Sydney Morning Herald was known for its scepticism of radicalism and its unsympathetic attitudes toward working-class political candidates in the region, especially in comparison to the more liberal Empire. ${ }^{93}$ Its initial partisanship toward the Claimant (and continued interest in the Tichborne movement) might have instead stemmed in part from its Protestant leanings, despite the paper's general avoidance of anti-Catholic sentiment. $^{94}$

As with the Madeleine Smith case, religious debate did not often feature in Australian coverage of the Tichborne case, but some newspapers did react to its anti-Catholic undertones. Freeman's Journal in Sydney condemned Kenealy's bigotry toward the Catholic Church during the criminal trial and recoiled at his remarks that if the Claimant was a liar, it was because he was taught by Jesuits. ${ }^{95}$ In contrast, the Protestant Standard was more shocked by how the Roman Catholic gentry had supposedly taught the Claimant to pray (incorrectly) to the Virgin Mary. ${ }^{96}$ The Protestant Standard was among those that heeded news of evidence in the Claimant's favour until the civil trial before it eventually denounced the Claimant on the grounds that 'all perjurers should be punished'. ${ }^{97}$

\footnotetext{
${ }^{90}$ Elizabeth Morrison, Engines of Influence: Newspapers of Country Victoria, 1840-1890 (Melbourne: Melbourne University Press, 2005), pp.18-19.

${ }^{91}$ Geelong Advertiser, 24 March 1874, p.2.

${ }^{92}$ Morrison, Engines of Influence, p.206.

${ }^{93}$ R. B. Walker, The Newspaper Press in New South Wales, 1803-1920 (Sydney: Sydney University Press, 1976), pp.58-59.

${ }^{94}$ Ibid, pp.81-82.

${ }^{95}$ Freeman's Journal, 21 March 1874, p.8.

${ }^{96}$ Protestant Standard, 3 August 1872, p.3.

${ }^{97}$ Ibid, 26 August 1871, p.6; 11 May 1872, p.4.
} 
Newspapers' positions on the Tichborne case also reflected the personal sensibilities of their editors. Simon Potter and Elizabeth Morrison have compared Australian newspaper proprietors and contributors to 'roving actors' who performed before any audience that could 'understand the language and respond to the play'. ${ }^{98}$ The Empire's readers, R. B. Walker asserts, were slightly lower in the social scale than those of the Sydney Morning Herald.${ }^{99}$ But while the newspaper's working-class sympathies and distrust of British aristocracy might not have shone through in support for the Claimant, they did through its persistent and almost unparalleled denouncement of the case's longevity and the upper echelons of the English legal system; it called barristers 'briefless' time-wasters. ${ }^{100}$ The Argus's interest in the case occurred during the editorship of Frederick Haddon, who was a long-time friend of Marcus Clarke and travelled with him to Tasmania in 1870, where Clarke gathered information on the colony's convict history for His Natural Life. ${ }^{101}$ Clarke also wrote columns for the Argus.

It was during the 1880s that the class composition of Tichborne followers in Australia became more concentrated, or at least more obvious, at a time when Tichbornism in Britain was beginning to wane. One of most enduring affidavits related to the case came from Parramatta, where it was alleged by the Claimant's Melbourne solicitors that the 'real' Arthur Orton had been traced to the Parramatta Lunatic Asylum. ${ }^{102}$ However, it was not until after the Claimant's criminal trial that his supporters made significant attempts to prove that the patient at the asylum was Orton. In 1877, Guildford Onslow appealed to the British public for funds to send the sister of Arthur Orton, Mina Jury, from Wapping to Parramatta to identify the patient and, if proved, bring him to London to be identified by the rest of the Orton family. ${ }^{103}$ On her arrival in Parramatta later that year, Jury was said to have recognised the patient (called 'William Cresswell') as her brother, and W. H. Lock, an agent for the National Tichborne Release Association in Victoria, petitioned the New South Wales government to release him. ${ }^{104}$ The petition to free Cresswell drew support from politician Joseph Eckford, who moved the motion

\footnotetext{
${ }^{98}$ Simon Potter, News and the British World: The Emergence of an Imperial Press System (Oxford: Oxford University Press, 2003), p.17; Elizabeth Morrison, 'Grub Street Inventor: James Harrison's Journalism, Old and New, in Geelong, Melbourne and London', in Denis Cryle (ed.), Disreputable Profession: Journalists and Journalism in Colonial Australia (Rockhampton: Central Queensland University Press, 1997), p.74.

${ }^{99}$ Walker, The Newspaper Press in New South Wales, pp.58-59.

${ }^{100}$ For example, see Empire, 11 September 1871, p.2.

${ }^{101}$ Argus, 16 December 1944, p.7; Carole Woods, 'Haddon, Frederick William (1839-1906)', Australian Dictionary of Biography, National Centre of Biography, Australian National University, https://adb.anu.edu.au/biography/haddon-frederick-william-3686/text5763, published first in hardcopy 1972, accessed 13 April 2021.

102 Age, 27 September 1871, p.3.

${ }^{103}$ SMH, 7 March 1877, p.7.

${ }^{104}$ SMH, 27 September 1877, p.5; Evening News (Sydney), 17 October 1877, p.5.
} 
in the New South Wales Legislative Assembly to release Cresswell and hand him over to Lock. ${ }^{105}$ Eckford's motion drew laughter from the assembly and was defeated by a vote of 294, with MP Michael Fitzpatrick declaring that the suggestion that Cresswell was Orton was 'the dying kick of the society in England pledged to get the Claimant out of prison'. ${ }^{106}$

Eckford's petition was merely the beginning of the Cresswell affair. Orton's brothers, Charles and Edward, also travelled from Britain to Australia, allegedly to identify the patient against evidence from the Cresswell family who claimed him as their own. ${ }^{107}$ The Tichborne Release Association held lectures across Sydney, and Jean Luie, a sailor and witness supporting the Claimant at the criminal trial who was found to be an imposter himself, also assisted the investigation into Cresswell's identity. ${ }^{108}$

Affidavits and failed petitions to release Cresswell continued to feature regularly in the newspaper press for years after the Claimant was released from prison in 1884. By 1889, 'fresh efforts' were being made to establish Cresswell as more than merely Arthur Orton but as the long-lost Roger Tichborne. ${ }^{109}$ Throughout the 1890 s, the rumour had gained extensive traction, and it was widely reported that 'many prominent citizens' supported the new Claimant's cause, including New South Wales Governor Robert Duff. ${ }^{110}$ Duff's backing led the Queanbeyan Observer triumphantly to declare that Cresswell had been positively identified as Tichborne. ${ }^{111}$ Others were less convinced, with the Evening News writing that 'it is astonishing how long a popular delusion lasts' and the Sydney Mail was startled not only by the fact that many people 'believe that the heir to the Tichborne Estates is not dead' but also by how many believe that Cresswell is the rightful heir. ${ }^{12}$ Portraits of Cresswell appeared in numerous newspapers (see Figure 6), a select committee was appointed by the New South Wales General Assembly in 1899 to conduct a detailed physical examination of Cresswell, and a Royal Commission was set up at the turn of the century, which ultimately found that Cresswell was neither Orton nor

\footnotetext{
${ }^{105}$ SMH, 1 May 1878, p.3.

${ }^{106}$ Ibid; $S M H, 27$ November 1878, p.3.

${ }^{107} \mathrm{SMH}, 31$ December 1884, p.6.

${ }^{108}$ Evening News (Sydney), 10 April 1883, p.3; 20 November 1883, p.3; South Australian Chronicle, 29 December 1894, p.21.

${ }^{109}$ Clarence and Richmond Examiner and New England Advertiser, 3 December 1889, p.4.

${ }^{110}$ For example, see Age, 20 December 1894, p.5; Daily Telegraph (Sydney), 25 December 1894, p.2;

Launceston Examiner, 25 December 1894, p.7.

${ }^{111}$ Queanbeyan Observer, 19 April 1895, p.3.

${ }^{112}$ Evening News (Sydney), 24 December 1894, p.5; Sydney Mail and New South Wales Advertiser, 8 May 1897, p.1003.
} 
Tichborne. ${ }^{113}$ By then, the Tichborne movement had run its course, the Clarence and Richmond Examiner declared exhaustedly, 'so far as the law is concerned, Sir Roger Tichborne is dead, and no human power can ever bring him to life again'. ${ }^{114}$

This content is unavailable. Please consult the figure list for further details.

Figure 6: 'Sir Roger Tichborne' and 'William Creswell' [sic], South Australian Chronicle, 29 December 1894, p.21.

The Cresswell affair became highly politicised and was strongly tied to the mobilisation of Australia's working classes. Droughts across Australia brought large numbers of newly unemployed workers and recent immigrants to metropolitan areas like Sydney, which preceded

${ }^{113}$ Evening News (Sydney), 23 November 1899, p.4; Janet C. Myers, Antipodal England: Emigration and Portable Domesticity in the Victorian Imagination (Albany:State University of New York Press, 2009), p.111; Roe, Kenealy and the Tichborne Cause, p.160.

${ }^{114}$ Clarence and Richmond Examiner, 24 February 1900, p.5. 
the mobilisation of metropolitan and suburban working-class communities from the late 1880 s. ${ }^{115}$ By the 1880 s, the populist ideologies of Australian radicalism found a 'sympathetic audience' among nationalistic 'working men' strongly opposed to the notion of a 'new imperialism', and thus the movement became an important basis for Australian national identity, as Robin Gollan and Henry Paternoster have argued. ${ }^{116}$ Populism in Australia was-and continues to be - often associated with nationalist and anti-immigrant politics and divisions between the 'people' and the 'elite'. ${ }^{117}$ In his advocacy for Cresswell's release, Daniel Smith mirrored these populist tendencies through his hostility to government-assisted immigration and squatting monopolists and his sympathy for Australia's working classes. ${ }^{118}$ Throughout his time in Australia, he 'mixed very little with any other class' because 'the so-called rich think more of themselves in Sydney than the aristocracy do in England'. ${ }^{119}$ Smith was reported to have regularly appealed to the working classes for funds to release Cresswell; when he did mix with a 'respectable' crowd at an 1883 lecture the Belfast Hotel in Sydney, he was met with a 'deafening roar' from hecklers telling him to 'dry up'. ${ }^{120}$

Other Australian 'Tichbornites' with populist ideologies included the politicians who supported Cresswell's release. Adolphus Taylor, who presented Daniel Smith's petition to release Cresswell to the New South Wales Legislative Assembly in 1884, later became the editor of Truth, a radical Sydney newspaper that variously promoted itself as an organ for the emerging labour movement and condemned other newspapers as the 'handmaidens of capitalism and corruption' before it became a scandal rag centred on 'crime, sex, sensualities, and personalities'. ${ }^{121}$ Later political supporters of the inquiry into Cresswell's release (and fellow radical journalists) included William Crick, a proprietor of Truth, and John Norton, Taylor's replacement as Truth's editor. ${ }^{122}$ Other journalistic ties included New South Wales MP and member of Henry Parkes's Free Trade Party, John Fitzpatrick, who was appointed chairman of a select committee (which later became a Royal Commission) to inquire into the Cresswell case

\footnotetext{
${ }^{115}$ Roe, Kenealy and the Tichborne Cause, p.153; Connell and Irving, Class Structure in Australian History, pp.188-189.

${ }^{116}$ Robin Gollan, Radical and Working Class Politics: A Study of Eastern Australia, 1850-1910 (Parkville: Melbourne University Press, 1960), p.112; Paternoster, Reimagining Class in Australia, p.33.

${ }^{117}$ Paternoster, Reimagining Class in Australia, pp.4, 13.

${ }^{118}$ Daniel Smith, Australia: A Warning to Intending Emigrants (London: Daniel Smith, 1885). See also Connell and Irving, Class Structure in Australian History, p.121.

119 Smith, Australia, p.5.

${ }^{120}$ Evening News (Sydney), 23 December 1882 p.3; Sydney Daily Telegraph, 28 June 1883, p.2.

${ }^{121}$ Walker, The Newspaper Press in New South Wales, pp.117-119.

${ }^{122}$ Ibid, p.118; Roe, Kenealy and the Tichborne Cause, p.160.
} 
in 1899. ${ }^{123}$ Fitzpatrick established and edited the Windsor and Richmond Gazette, which published articles sympathetic to his view that Cresswell be released. ${ }^{124}$

Fitzpatrick's earlier 1898 motion to the Legislative Assembly for an inquiry into the Cresswell case drew support from many members of the emerging Labor Party (then called the Labor Electoral League of New South Wales), but it was defeated by 30 votes to $29 .{ }^{125}$ Support for Cresswell's release was not always politically partisan. For many, proving that Cresswell was the true heir was - like Tichbornism in Britain — only part of a broader effort to ensure that he was given fair treatment, irrespective of political party. As Free Trade Party MP Edward Clark contested, 'whether he is Tichborne or Creswell [sic], he has been detained thirty years in a lunatic asylum, and he has no right to be detained there any longer'. ${ }^{126}$ For others, like Protectionist MP, Robert Levien, establishment conspiracy and other influences were also at work 'which some day will cause certain public individuals in this country to regret the opposition they have shown in regard to this matter'. ${ }^{27}$

In all these efforts, the concept of the 'people' pitted against officials, parliamentarians, and the English legal establishment transcended the concept of class. Such an ideology became an important theme in Australian history, R. W. Connell points out; "the idea of the people being threatened by a conspiratorial clique seizing power through the state apparatus is a schema that repeatedly surfaces in country politics as well as urban conservatism and fiscal radicalism'. ${ }^{28}$ While the populist undertones of Tichbornites in Australia might not have amounted to a widespread movement as in Britain, the individuals concerned were nonetheless highly vocal and wielded enough political power for newspapers to give them a platform.

Roe has associated political figures like Taylor, Crick, Norton, Fitzpatrick, and others with the recurring stereotype of the political leader in Australia as a 'larrikin'. ${ }^{129}$ During the nineteenth century, 'larrikin' was a negative term synonymous with 'hoodlum' or 'young scoundrel', often applied to unskilled labour and working-class groups. ${ }^{130}$ Populism and

\footnotetext{
${ }^{123}$ Votes and Proceedings of the Legislative Assembly of New South Wales, 9 August 1900, p.201.

${ }^{124}$ For example, see Windsor and Richmond Gazette, 1 August 1896, p.5; 5 September 1896, p.6; 28 October 1899 , p.9.

125 'Case of William Cresswell', NSWPD, 4 October 1898, pp.1054-1057. See also Roe, Kenealy and the Tichborne Cause, p.161.

126 'William Cresswell', NSWPD, 9 August 1900, p.1819.

${ }^{127}$ Ibid, p. 1817.

${ }^{128}$ R. W. Connell, ‘Wagga’s Butcher, Tichborne’s Claimant, Kenealy’s Cause', Meanjin Quarterly, Vol. 34, no. 1,1975, p.102.

${ }^{129}$ Roe, Kenealy and the Tichborne Cause, pp.196-197.

${ }^{130}$ Melissa Bellanta, Larrikins: A History (St Lucia: University of Queensland Press, 2012), pp.xiv, 10.
} 
larrikinism in Australia, Roe argues, had close ties to liquor, sport, scandal, and sensational journalism, all of which Taylor, Crick, Norton, Fitzpatrick-and indeed the Claimantpersonified. ${ }^{131}$ Their spearheading of the Cresswell release movement represented how politicised, provocative, and localised a metropolitan scandal could become. In the same way that the Madeleine Smith case was transplanted into, while also igniting, colonial debates over ex-convicts and criminality, the Tichborne case was harnessed as a political tool by various party constituents.

This chapter has demonstrated that debates about class and respectability in Australian coverage of the Tichborne and Madeleine Smith cases became highly politicised and closely associated with Australia's convict history and mounting antipathy toward the metropole. Fears of 'undesirable' and often monied 'unproductive' Britons settling in the colony, evoked by the Smith case, were contemporaneous with anxieties about how Britons 'at home' saw colonists as lowly and illegitimate, as the Tichborne case and the work of Marcus Clarke evoked. Questions about the true identities of the Claimant and William Cresswell, combined with Smith's purported retreat from Britain, show how both cases reinforced the notions that identity could be concealed in the colony and that Australia was thus a place with more fluid class mobility than Britain. Nonetheless, newspapers were highly class consciousness in the way they reported on the cases, as references to 'respectability' (or Smith's and the Claimant's lack thereof) saturated coverage of both cases, even if newspapers' own class positions and political leanings did not always inform their attitudes. Both cases were to various extents used as political tools, whether in the anti-transportation arguments of Edward Wilson and by critics of William Booth's transnational colonial network scheme in Smith's case, or in the radical movement of Australian politicians supporting the Tichborne case.

\footnotetext{
${ }^{131}$ Roe, Kenealy and the Tichborne Cause, pp.196-197.
} 



\section{Conclusion}

Wild speculation surrounding Madeleine Smith's whereabouts extended well into the twentieth century. In 1927, it was rumoured that a Hollywood film production company approached Smith, now ill, impoverished, and living in New York, requesting her to star in an upcoming film based on her life. Averse to public attention, she purportedly declined, and was threatened with deportation to Britain unless she consented. ${ }^{1}$ The resulting publicity reinvigorated interest in the case and corresponded with the release of criminologist F. Tennyson Jesse's seminal account of the trial. Despite being considered an 'undesirable alien' by newspapers in the United States, Smith stayed in the country until her death the following year. ${ }^{2}$ Hearsay surrounding Smith's life prevailed, and at a time when serial fiction centred on crime and criminals across colonial newspapers continued to grow, newspapers continued to heed the narrative that she escaped to Australia. ${ }^{3}$ Denying rumours that Smith met with film executives, Gordon and Nair assert that she 'put unpleasantness behind her', never broke her silence about L'Angelier, and kept to circles where her notorious past could be accepted. ${ }^{4}$ Nonetheless, the stories about her have depicted her in many ways: 'an independent free spirit born before her time, the sexually alluring vamp, the victim of an ideological straitjacket, the prisoner of powerful discourses, the epitome of female duplicity, and the hero of her own life' ${ }^{5}$ By examining how and why the Australian colonial press reported on Smith and contributed to her case becoming an item of cultural, social, and legal significance in the colony, this thesis has added another analysis to that scholarship.

Smith's place as a cultural colonial phenomenon prevailed at various times and across new mediums in the twentieth century, from historical accounts and inclusions in voluminous books devoted to famous British criminal trials to radio plays and a 1950 film directed by David

\footnotetext{
1 'Revelations of a Non-Proven Murder Case After Seventy Years', Australian Women's Mirror, Vol. 29, no. 8, 14 January 1953, pp.3, 13.

${ }^{2}$ Australasian, 9 June 1928, p.6; Eleanor Gordon and Gwyneth Nair, Murder and Morality in Victorian Britain: The Story of Madeleine Smith (Manchester: Manchester University Press, 2010), p.188.

${ }^{3}$ Elizabeth Morrison, 'Serial fiction in Australian colonial newspapers', in John O. Jordan and Robert L. Patten (eds.), Literature in the Marketplace: Nineteenth-century British publishing and reading practices (Cambridge: Cambridge University Press, 1995), p.309. For examples of newspapers heeding the hearsay, see Telegraph (Brisbane), 5 April 1924, p.15; Morning Bulletin (Rockhampton), 11 August 1924, p.7; Argus, 31 January 1925, p.7; Daily Standard (Brisbane), 2 February 1935, p.7; World's News (Sydney), 22 September 1937, p.10; The Mail (Adelaide), 3 July 1954, p.2; Western Mail, 6 January 1955, pp.10-11.

${ }^{4}$ Gordon and Nair, Murder and Morality, pp.188-189.

5 Ibid, p. 171.
} 
Lean. Australia's cultural entanglement with the case also continued. In 1935, an account of the trial was retold by Australian entertainers Harry Borrodale and Frank Haining and broadcasted by radio across the country as part of a 'famous crimes in retrospect' series. ${ }^{6} \mathrm{~A}$ Scottish theatre play entitled 'The Story of Madeline [sic] Smith' was reproduced in Australia and performed by the 'Kurung-gai Theatre Guild' in Sydney in 1949.7 A 1958 live television play based on the trial was one of the Australian Broadcasting Commission's earliest productions and was the final feature of George Kerr's four-part anthology series, 'Killer in Close-Up', which centred on notable British murder trials. ${ }^{8}$ Additionally, English celebrity biographer, Charles Higham, penned a poem about Smith in 1966 while he was living in Australia and writing for the Bulletin. ${ }^{9}$

Just as many British stories of the Smith case were born out of feelings of 'reactionary nostalgia' centred on the Victorian era, as Gordon and Nair note, so memories of both Smith and the Claimant in Australia were products of their own contemporary cultural, social, and emotional landscapes. ${ }^{10}$ National identity, recollections of the nineteenth-century gold rush, and representations of Australia as a distant refuge for ex-criminals pervaded twentieth-century coverage of both cases and retrospective stories of their associations with Australia. As the Australasian wrote upon hearing of Smith's death in 1928:

[Smith's death is] an occurrence which revives the memory of a famous trial of nearly 71 years ago, a trial which excited widespread attention not only in the old country but also in Australia, for the gold era (then at its height) had attracted many thousands of persons hitherward, and "news from home" was read with supreme interest by recent arrivals. Moreover, after the trial was over, Madeleine Smith was supposed to have come to Australia, as many others had done, to be forgotten, and to begin life anew. ${ }^{11}$

The question of Smith's guilt- 'wherever newspapers in the English language were read, or for that matter newspapers in any language', as the Evening News opined in 1911-lingered on, and was reinvigorated by new discourse, new evidence, and changing social contexts. ${ }^{12}$

The Claimant's story followed a similar trajectory to Smith's. Following his release from prison in 1884, after serving ten years of his fourteen-year sentence, the Claimant emerged much thinner; Kenealy's death in 1880, the Claimant's lack of interest in the

\footnotetext{
${ }^{6}$ For example, see Sun (Sydney), 9 June 1935, p.25; Weekly Times (Melbourne), 12 October 1935, p.2; Telegraph (Brisbane), 14 October 1935, p.24.

${ }^{7}$ Sun (Sydney), 9 September 1949, p.17.

${ }^{8}$ SMH, 11 August 1958, p.11.

${ }^{9}$ Charles Higham, 'The Saga of Madeleine Smith', Bulletin, 9 July 1966, p.39.

${ }^{10}$ Gordon and Nair, Murder and Morality, pp.168-169.

${ }^{11}$ Australasian, 9 June 1928, p.6.

${ }^{12}$ Evening News (Sydney), 12 December 1911, p.14.
} 
Tichborne movement and its outcropping, the Magna Charta Association, the removal of his waxwork at Madame Tussaud's in London in 1891, and the demise of the Englishman publication in 1886 contributed to the Claimant's descent into relative obscurity in Britain, despite Australian interest in the case burgeoning around the Cresswell affair. ${ }^{13}$ In 1895 , the Claimant confessed to the British tabloid newspaper, The People, that he was indeed Arthur Orton, shocking old Tichbornites, including Maurice Kenealy (Edward's son), William Alfred Frost, and H. B. Harding, who insisted on prosecuting the Claimant for perjury. ${ }^{14}$

The Claimant's confession was covered by newspapers across Australia and excited 'more than the usual amount of interest' in Wagga Wagga, as the Wagga Wagga Express reported. ${ }^{15}$ It added more complications to the efforts to release Cresswell, although many newspapers continued to report on the Cresswell movement as if the confession had little effect, particularly in the minds of the conspirators spearheading it. As the Age wrote, 'it is satisfactory that Orton has at last confessed, since his doing so will remove the lingering doubt in many minds that injustice was meted out to the Claimant, and afford proof that in this case at least an English court of law arrived at a righteous decision'. ${ }^{16}$ Despite the Claimant's loss of wealth and support, writer and humourist Mark Twain recalled during his visit to Australia in 1896 that Wagga Wagga's name still resonated across the world as a result of the case. 'It was out of the midst of his humble collection of sausages and tripe', Twain wrote, 'that he soared up into the zenith of notoriety and hung there in the wastes of space a time, with the telescopes of all nations'. ${ }^{17}$ By 1897, the Claimant rescinded his confession to being Orton, was evicted from his lodging in London, and-like Smith-died in poverty, in $1898 .{ }^{18}$ While newspapers obituarised him as Arthur Orton, he was buried under the name of 'Sir Roger Charles Doughty Tichborne', with the Tichborne family's permission. ${ }^{19}$

Cultural fascination with the Claimant in the twentieth century resonated in novels inspired by the case, accounts of notable nineteenth-century criminal trials, and in the British

\footnotetext{
${ }^{13}$ Rohan McWilliam, The Tichborne Claimant: A Victorian Sensation (London: Hambledon Continuum, 2007), pp.183-185, 276.

${ }^{14}$ Ibid, pp.271-273, 276.

${ }^{15}$ WWE, 2 July 1895, p. 2 .

${ }^{16}$ Age, 20 May 1895, p.4.

${ }^{17}$ Mark Twain, Following the Equator: A Journey around the World, Vol. I (New York; London: Harper and Brothers Publishers, 1899), p.155.

${ }^{18}$ McWilliam, The Tichborne Claimant, pp.272-273. See also L. C. Collins (ed.), Life and Memoirs of John Churton Collins (London: The Bodley Head, 1912), pp.191-198.

${ }^{19}$ Max Everest-Phillips, 'The 1871 'Tichborne Claimant' medal', p.12; Robyn Annear, The Man Who Lost Himself: The Unbelievable Story of the Tichborne Claimant (Melbourne: The Text Publishing Company, 2002), p. 273 .
} 
film, The Tichborne Claimant, told through the eyes of Tichborne family servant, Andrew Bogle, and released on the anniversary of the Claimant's death, in $1998 .{ }^{20}$ Histories of the case sprouted variously in Australian newspapers, sometimes purporting to have new evidence pertaining to his life and death, and often reminding readers of how a lowly local butcher had duped many across the empire. In 1949, some newspapers gave voice to the discovery of a statement by Catholic priest, Patrick Dunne, in 1895, which suggested that Roger Tichborne had died as a pauper in Geelong. ${ }^{21}$ Interest in the case was again renewed in 1951 as part of George Blaikie's 'Our Strange Past' series in The Mail, which supported the idea that Bogle tutored the Claimant in an elaborate attempt to seek justice for the way the Tichborne family had treated him. ${ }^{22}$ The Claimant 'played his part magnificently', the paper wrote, 'he offended nobody, and took particular care to accommodate every tradesman who sought his patronage'. ${ }^{23}$ Once adorning the mantelpieces of Victorian homes, paintings, medallions, cartes de visite, figurines, glassware, pamphlets, and other forms of Tichborne memorabilia continue to survive as material manifestations of the cultural excitement that the case stirred, whether displayed patriotically at the Wagga Wagga Council Chambers, housed in the Museum of the Riverina's permanent collections, or hidden in the archives. $^{24}$

By examining coverage of the Smith case alongside that of the Tichborne Claimant's, this thesis has explored how newspapers not only brought news from metropole to colony, but also served as vehicles for debate, operating variously as windows into how other societies worked as well as mirrors that provoked self-reflection and enabled readers to make sense of their lives. In colonial Australian society, newspapers were a 'necessity of life' and a material signifier of imperial progress. ${ }^{25}$ The vast, detailed coverage of both the Smith and Tichborne cases in Australia shows how enthusiastic and well-informed British settlers in Australia were in absorbing overseas news from 'home'.

\footnotetext{
${ }^{20}$ McWilliam, The Tichborne Claimant, p.276.

${ }^{21}$ For example, see Advocate, 13 October 1949, p.11.

22 The Mail (Adelaide), 11 August 1951, pp.4-5.

${ }^{23}$ Ibid, p.4.

24 'The Greatest Impostor in History: Souvenir figurines of the Tichborne Trials', Museum of the Riverina, https://museumriverina.com.au/collections/highlights/the-greatest-impostor-in-history\#.YK2cDqgzaUk, accessed 26 May 2021; 'Tichborne carte de visite', Museum of the Riverina, https://museumriverina.com.au/collections/highlights/tichborne-carte-de-visite\#.YK2cDagzaUk, accessed 26 May 2021; McWilliam, The Tichborne Claimant, p.278.

${ }^{25}$ Sam Hutchinson, Settlers, War, and Empire in the Press: Unsettling News in Australia and Britain, 18631902 (Cham: Palgrave Macmillan, 2018), p.6.
} 
Questions of nationhood and identity underscored coverage of the Smith and Tichborne cases. 'Colonial identity cannot be understood in isolation', as Kirsten McKenzie points out, 'it was connected under the constantly imagined gaze of the metropole' ${ }^{26}$ Both cases could evoke feelings of nostalgia and connection to the metropole at a time when a distinct Australian identity was being cultivated. Cultural fascination with the Smith case corresponded with an emerging Scottish diaspora in parts of Australia. Despite existing scholarship on the colonial attachment to Scottish cult figures, such as Robert Burns and William Wallace, there is a dearth of scholarship that has assessed the significance of criminals or associated persons as icons of nationhood that might have triggered nostalgia or sparked pride. Reported sightings of Smith, her place in colonial wax museums, subjective recollections of the trial by contributors to newspapers, and associated debates over Scots law showed how Smith could also be viewed as an icon of hybrid Scottish, Australian, and British nationhood; her case raised awareness of the 'not proven' verdict and, to varying degrees, showed how Scottish distinctiveness could be consolidated in a colonial context.

Australian newspaper coverage of the cases was as much of a reaction to the cases themselves as it was a response to the ways in which British newspapers reported on them. Cultural fascination with the Tichborne case similarly contributed to British and colonial Australian stereotypes of Australia, which local newspapers both heeded and scorned. In their ability to enrapture, enlighten, and inform readers across disparate sites of the empire, newspapers were also susceptible to the often-uncontrollable side effects of gossip and misinformation. They allowed readers to 'write back' to editors and other contributors, thus becoming forums for public debate. Smith's reported presence in Australia and numerous detailed but often implausible affidavits supporting the Claimant show how the spread of news was never one-directional and 'cut and paste' colonial newspaper networks were not always unified. The notion that colonial media outlets resembled and deviated from their British counterparts, and each other, in their coverage of the cases is significant in that it reveals the fluidity of local and national identity formation.

Diversity of thought and feeling was particularly prominent in discussions surrounding the appearance, demeanour, and sexuality of Smith and the Tichborne Claimant, which have not previously been discussed in a colonial context. Observers in both Britain and Australia associated Smith's guilt and the Claimant's insincerity (or lack thereof) with their gender.

\footnotetext{
${ }^{26}$ Kirsten McKenzie, Scandal in the Colonies (Melbourne: Melbourne University Press, 2005), p.12.
} 
Concern over sensational crimes corrupting the minds of young men and women in Australia grew out of men's fixations with Smith and other 'murderesses', paralleling contemporary debates over capital punishment and gender bias in English law. Similarly, the Claimant's appearance and sexuality became fodder for his detractors. Australian newspapers variously associated the Claimant with Australian masculinity, expressed most vociferously in cartoons, songs, poems, puns, caricatures, and other items of biting satire.

Both cases bring attention to the often overlooked and understudied concept of class in colonial Australia. Although class debates were not as prominent in coverage of the cases in Australia as they were in Britain, debate about 'respectability' was central to discourse on both cases and took on a different meaning for white colonial Australians. In the Smith case, her social position stood at the fore in Australian newspapers. Many newspapers associated the issue of celebrity worshipping with concerns over crime being committed by the wealthy classes in Britain, grievances over Australia's ex-convict label, and the migration of unwanted Britons amidst the nation's growing nationalism. Like the Smith case, class consciousness pervaded much of the coverage of the Tichborne case, even if it did not always inform attitudes toward his cause. Attitudes toward the Claimant in Australia were often far more complicated than those in Britain, as class, social, and political positions of newspapers did not always inform their partisanship. The Tichborne movement in Australia unfolded in a more individualised, rather than collective, manner. ${ }^{27}$ Just as the Smith case became associated with discussion on colonial law, so the Tichborne case became stoutly political (and the class consciousness of its followers more obvious), as petitions to release Cresswell became enmeshed with the broader populist ideologies and working-class sympathies of the politicians that led them.

The Smith and Tichborne cases are only two of many British criminal trials that became sensations in the mid-late nineteenth century. But they were, as this thesis has found, significant in the way they were harnessed to the communicative powers of the newspaper press, transfixed readers at different sites of the empire, and prompted reassessments of identity. By way of the 'not proven' verdict, the 'jury is still out' in Smith's case, and the verdicts and debates over the Tichborne Claimant's identity were likewise far from the decisive end-points that past trial accounts often purported them to be. Thus, this thesis has purposefully avoided weighing in on the veracity of the cases. Questions as to whether Smith murdered L'Angelier or whether the

\footnotetext{
${ }^{27}$ Michael Roe, Kenealy and the Tichborne Cause: A Study in Mid-Victorian Populism (Melbourne: Melbourne University Press, 1974), p.195.
} 
Claimant was indeed Roger Tichborne were in many ways merely the provocateurs of the farreaching and wide-ranging social debate that ensued both in Britain and in Australia. 



\section{Bibliography}

\section{Primary Sources}

\section{Official Published Material}

British Parliamentary Debates

New South Wales Parliamentary Debates

New Zealand Parliamentary Debates

Victoria Parliamentary Debates

Votes and Proceedings of the Legislative Assembly of New South Wales

\section{Newspapers, Gazettes, Magazines, and Journals}

Britain:

Aberdeen Evening Express

Aberdeen Press and Journal

Ayrshire Express

Blackwood's Edinburgh Magazine

British Quarterly Review

Caledonian Mercury

Chambers's Journal of Popular Literature Science and Arts

Dorset County Chronicle

Dundee Courier

Dundee, Perth, and Cupar Advertiser

Edinburgh Evening Courant

Edinburgh Evening News

Edinburgh Evening Post and Scottish Record

The Englishman

The Examiner

Glasgow Courier

Glasgow Free Press 
Glasgow Herald

Glasgow Sentinel

Globe (London)

The Graphic

Judy; or, the London Serio-Comic Journal

Leeds Mercury

London Evening Standard

Morning Advertiser

Morning Post

Newcastle Evening Chronicle

Observer

Pall Mall Gazette

Perthshire Courier

Punch; or, The London Charivari

The Saturday Review of Politics, Literature, Science and Art

The Scotsman

Southampton Times

The Spectator: A Weekly Journal of News, Politics, Literature, and Science

St James's Gazette

Standard

Star (London)

Tichborne Gazette

Tichborne News and Anti-Oppression Journal: A Weekly Newspaper Advocating Fair Play for Every Man

The Times

Witness (Edinburgh)

Australia:

Adelaide Express

Adelaide Observer

Adelong and Tumut Express and Tumbarumba Post

Advertiser (Adelaide) 
Advocate

Age

Albury Banner and Wodonga Express

Argus

Armidale Express and New England General Advertiser

Australasian

Australian Star

Australian Town and Country Journal

Avoca Mail

Ballarat Courier

Ballarat Star

Bathurst Free Press and Mining Journal

Bell's Life in Sydney and Sporting Chronicle

Bell's Life in Victoria and Sporting Chronicle

Bendigo Advertiser

Border Watch

Brisbane Courier

Bunyip

Burrangong Argus

Burrowa News

Clarence and Richmond Examiner

Clarence and Richmond Examiner and New England Advertiser

Cornwall Advertiser

Cornwall Chronicle

Daily News (Perth)

Daily Northern Argus

Daily Standard (Brisbane)

Daily Telegraph (Launceston)

Daily Telegraph (Sydney)

Darling Downs Gazette and General Advertiser

Dubbo Dispatch and Wellington Independent

Empire (Sydney) 
Evening Journal (Adelaide)

Evening News

Examiner (Launceston)

Express and Telegraph

Freeman's Journal

Geelong Advertiser

Gippsland Times

Glen Innes Examiner and General Advertiser

Goulburn Herald

Goulburn Herald and County of Argyle Advertiser

Goulburn Herald and Chronicle

Gundagai Times and Tumut, Adelong and Murrumbidgee District Advertiser

Hamilton Spectator and Grange District Advertiser

Hay Standard and Advertiser for Balranald, Wentworth, Maude, Booligal, Wilcannia, Menindie, Bourke, \&c.

Herald (Melbourne)

Hobart Town Mercury

Illawarra Mercury

Illustrated Australian News for Home Readers

Illustrated Sydney News

Illustrated Sydney News and New South Wales Agriculturalist and Grazier

Inquirer and Commercial News

Kapunda Herald and Northern Intelligencer

Kilmore Free Press

Kyneton Observer

Launceston Examiner

Leader (Melbourne)

Lorgnette

Mackay Mercury and South Kennedy Advertiser

The Mail (Adelaide)

Maitland Mercury

Maitland Mercury and Hunter River General Advertiser 
Maryborough and Dunolly Advertiser

Maryborough Chronicle, Wide Bay and Burnett Advertiser

Melbourne Punch

Mercury

Morning Bulletin (Rockhampton)

Mount Alexander Mail

Murrurundi Times and Liverpool Plains Gazette

National Advocate (Bathurst)

Newcastle Chronicle

Newcastle Morning Herald and Miners' Advocate

North Australian, Ipswich and General Advertiser

Northern Argus

Northern Times

Ovens and Murray Advertiser

Perth Gazette and Independent Journal of Politics and News

Port Augusta Dispatch, Newcastle and Flinders Chronicle

Port Melbourne Standard

Portland Guardian and Normanby General Advertiser

Protestant Standard

Public Opinion

Queanbeyan Age

Queensland Times, Ipswich Herald and General Advertiser

Queenslander

Riverine Grazier

Riverine Herald

Shoalhaven News, Ulladulla and Southern Coast Districts Advertiser

South Australian Advertiser

South Australian Chronicle

South Australian Chronicle and Weekly Advertiser

South Australian Chronicle and Weekly Mail

South Australian Register

Southern Argus 
Star (Ballarat)

Sun (Sydney)

Sydney Daily Telegraph

Sydney Mail

Sydney Mail and New South Wales Advertiser

Sydney Morning Herald

Sydney Punch

Tasmanian Daily News

Tasmanian Tribune

Telegraph (Brisbane)

The Telegraph, St Kilda, Prahran and South Yarra Guardian

Toowoomba Chronicle and Queensland Advertiser

Truth (Sydney)

Tumut and Adelong Times

Wagga Wagga Advertiser

Wagga Wagga Advertiser and New South Wales Chronicle

Wagga Wagga Advertiser and Riverine Reporter

Wagga Wagga Express

Wagga Wagga Express and Murrumbidgee District Advertiser

Wallaroo Times and Mining Journal

Warwick Argus and Tenterfield Chronicle

Weekly Examiner

Weekly Times (Melbourne)

West Australian

Western Mail

Windsor and Richmond Gazette

World's News (Sydney)

New Zealand:

Auckland Star

Clutha Leader

Colonist 
Cromwell Argus

Daily Southern Cross

Daily Telegraph (Napier)

Evening Post

Evening Star

Inangahua Times

Lyttelton Times

Nelson Evening Mail

Nelson Examiner and New Zealand Chronicle

New Zealander

New Zealand Herald

New Zealand Mail

Otago Daily Times

Otago Witness

Press (Christchurch)

Southland Times

Star (Christchurch)

Temuka Leader

Wanganui Herald

\section{Books}

Allen, J. S. O. Memories of My Life: From My Early Days in Scotland Till the Present Day in Adelaide (Adelaide: J. L. Bonython \& Co., "The Advertiser" Office, 1906).

Atlay, James Beresford. Famous Trials of the Century (London: Grant Richards, 1899).

Ballantine, Mr. Sergeant. Some Experiences of a Barrister's Life (New York: Henry Holt and Company, 1882).

Booth, William. In Darkest England and the Way Out (London: International Headquarters of the Salvation Army, 1890).

Clarke, Marcus. For the Term of His Natural Life (London: Oxford University Press, 1957. First published in 1874).

Collins, L. C. (ed.). Life and Memoirs of John Churton Collins (London: The Bodley Head, 1912).

Coopland, R. M. A Lady's Escape from Gawlior, and Life in the Fort of Agra during the Mutinies of 1857 (London: Smith, Elder, and Co., 1859). 
Crawford, James Coutts. Recollections of Travel in New Zealand and Australia: A Journey from New Zealand to Tasmania and Australia (London: Trübner and Co., 1880).

Ellis, Ellen E. Everything is Possible to Will [annotated by Rosalie Elliffe] (London: 63 Fleet Street, 1882), retrieved from http://nzetc.victoria.ac.nz/tm/scholarly/teiRosEver.html.

Fenton, James. A History of Tasmania (Hobart: J. Walch and Sons; Launceston: Walch Brothers and Birchall, 1884).

Gurnell, R. M. A Critical Review of the Tichborne Trial (London: W. Wilfred Head, 1876).

Kenealy, Maurice. The Tichborne Tragedy (London: Francis Griffiths, 1913).

Kelvin, Norman (ed.). The Collected Letters of William Morris, Volume II, Part B, 18851888 (Princeton: Princeton University Press, 1995).

Matthews, William. Identity Demonstrated Geometrically: With Phototype Illustrations (Bristol: J. Wright, 1876).

Melville, A. G. 'The book trade in Australia since 1861', in Library Association of Australasia, Proceedings of Sydney Meeting, 1898 (Sydney: Hennesey, Harper \& Company, Printers and Publishers, 1899), pp.107-115.

Mineka, Francis E. and Dwight N. Lindley (eds.). The Later Letters of John Stuart Mill 1849-1973, Vol. XVI (Toronto: University of Toronto Press, 1972).

Morse, Jr., John T. Famous Trials: The Tichborne Claimant, Troppmann, Prince Pierre Bonaparte, Mrs. Wharton, The Meteor, Mrs. Fair (Boston: Little, Brown, and Company, 1874).

Peirce, A. B. Knocking About: Being Some Adventures of Augustus Baker Peirce in Australia (New Haven: Yale University Press, 1924).

Pratt, Ambrose. David Syme: The Father of Protection in Australia (London and Melbourne: Ward Lock \& Co Ltd., 1908).

The Story of Minie L'Angelier or Madeleine Hamilton Smith (Edinburgh: Myles Macphail; Glasgow: T. Murray \& Son; London: Simpkin, Marshall \& Co., 1857).

Trollope, Anthony. Australia and New Zealand, Volume I (Leipzig: Bernhard Tauchnitz, 1873).

Twain, Mark. Following the Equator: A Journey around the World, Vol. I (New York; London: Harper and Brothers Publishers, 1899).

Watt, James Crabb. John Inglis, Lord Justice-General of Scotland: A Memoir (Edinburgh: William Green \& Sons, 1893).

\section{Trial Reports}

Browne, G. Lathom and C. G. Stewart. Reports of Trials for Murder By Poisoning; by Prussic Acid, Strychnia, Antimony, Arsenic, and Aconitia. Including the Trials of Tawell, W. Palmer, Dove, Madeleine Smith, Dr. Pritchard, Smethurst, and Dr. Lamson, with chemical introduction and notes on the poisons used (London: Stevens and Sons, 1883). 
Irvine, Alexander Forbes. Report on the Trial of Madeleine Smith: before the High Court of Justiciary at Edinburgh, June 30th to July 9th, 1857, for the alleged poisoning of Pierre Émile L'Angelier (Edinburgh: T. \& T. Clark, Law Booksellers, George Street; Glasgow: Smith and Son; Aberdeen: Wyllie and Son; London: Stevens \& Norton, \& and Sympkin \& Co., 1857).

Kenealy, Edward (ed.), The Trial at Bar of Sir Roger C. D. Tichborne, Bart., in the Court of Queen's Bench at Westminster, before Lord Chief Justice Cockburn, Mr. Justice Mellor, and Mr. Justice Lush, for Perjury: Volumes I-IV (London: "Englishman" Office, 1877).

Morison, John. A Complete Report of the Trial of Miss Madeline Smith, for the Alleged Poisoning of Pierre Emile L'Angelier (Edinburgh: W. P. Nimmo, 1857).

The Tichborne Romance: A Full and Accurate Report of the Proceedings in the Extraordinary and Interesting Trial of Tichborne v. Lushington, in the Court of Common Pleas, Westminster, for Forty Days, from Wednesday, May 10 to Friday, July 7, 1871; Including the Whole of the Examination, Cross-Examination, and ReExamination of the Claimant 3 (Manchester: John Hayward; London: Simpkin, Marshall, \& Co., 1871).

The Tichborne Trial: The Summing Up of the Lord Chief Justice of England, Together with the Addresses of the Judges, the Verdict, and the Sentence, the Whole Accompanied by a History of the Case and Copious Alphabetical Index (London: Ward, Locke, and Tyler, 1874).

\section{Pamphlets and Other Published Material}

The Annual Register, or a View of the History, Politics, and Literature, for the Year 1857 (London: F. \& J. Rivington, 1857).

The Annual Register: A Review of Public Events at Home and Abroad, for the Year 1871 (London: Rivingtons, 1872).

The Annual Register: A Review of Public Events at Home and Abroad, for the Year 1874 (London: Rivingtons, 1875).

'Budgery'. Miss Madeline Smith: The Glasgow Poisoning Case. A Tale of "Scotch Mist"ery, Entitled Emile and Madeline; or Love and Murder (Melbourne: Melbourne Herald Office, 1857).

Catalogue of Madame Sohier's Australian Waxworks Exhibition, Great Bourke Street East, Melbourne (Melbourne: Clarson, Shallard, \& Co., 1862).

Catalogue of Madame Sohier's Waxworks Exhibition, Bourke Street East, Melbourne, and Pitt Street, Sydney (Melbourne: Wilson \& Mackinnon, Printers, 1865).

Catalogue of Madame Sohier's Waxworks Exhibition, Bourke Street East, Melbourne, and Pitt Street, Sydney (Melbourne: Wilson \& Mackinnon, Printers, 1866).

'The Defects in the Evidence of the Glasgow Poisoning Case', in Jacob Bell (ed.), Pharmaceutical Journal and Transactions. Volume XVII. 1857-58 (London: John Churchill, New Burlington Street; Edinburgh: Maclachlan \& Stewart; Dublin: Fannin \& Co., 1858), pp.114-115. 
Frank Leslie's Popular Monthly: Vol. X-July to December, 1880 (New York: Frank Leslie's Publishing House, 1880).

Harvard Law Review, Vol. VIII. 1894-95 (Cambridge, MA: The Harvard Law Review Publishing Association, 1895).

Jackson, John Dettmer Dodds. Sir Roger Tichborne Revealed!: The Discovery of Sir Roger Charles Doughty Tichborne alias Edward Caleb Souper, secretary to Lady Ogle of Withdeane Court near Brighton, Sussex, England, and his confederates (Sydney: H. Garforth, Printer, 1885).

Smith, Daniel. Australia: A Warning to Intending Emigrants (London: Daniel Smith, 1885). 


\section{Secondary Sources}

\section{Books}

Altick, Richard D. Victorian Studies in Scarlet (London: J. M. Dent \& Sons Ltd., 1972).

Anderson, Benedict. Imagined Communities: Reflections on the Origin and Spread of Nationalism (London and New York: Verso, 2006. First published in 1983).

Anderson, Hugh (ed.). Baronet or Butcher? The Trials of the Tichborne Claimant (Victoria: Red Rooster Press, 1999).

Annear, Robyn. The Man Who Lost Himself: The Unbelievable Story of the Tichborne Claimant (Melbourne: The Text Publishing Company, 2002).

Arneil, Barbara. Domestic Colonies: The Turn Inward to Colony (Oxford: Oxford University Press, 2017).

Ballantyne, Tony. Webs of Empire: Locating New Zealand's Colonial Past (Wellington: Bridget Williams Books, 2012).

Bellanta, Melissa. Larrikins: A History (St Lucia: University of Queensland Press, 2012).

Bishop, Catherine. Minding Her Own Business: Colonial Businesswomen in Sydney (Sydney: NewSouth Publishing, 2015).

Bueltmann, Tanja. Clubbing Together: Ethnicity, Civility and Formal Sociability in the Scottish Diaspora To 1930 (Liverpool: Liverpool University Press, 2014).

Cain, Peter (ed.). Empire and Imperialism: The Debate of the 1870s (South Bend, Indiana: St. Augustine's Press, 1999).

Carey, Hilary M. Empire of Hell: Religion and the Campaign to End Convict Transportation in the British Empire, 1788-1875 (Cambridge: Cambridge University Press, 2019).

Cavallaro, Dani and Alexandra Warwick. Fashioning the Frame: Boundaries, Dress and the Body (Oxford and New York: Berg, 1998).

Connell, R. W. and T. H. Irving. Class Structure in Australian History: Documents, Narrative and Argument (Melbourne: Longman Cheshire, 1986. First published in 1980).

Diamond, Michael. Victorian Sensation: Or, the Spectacular, the Shocking and the Scandalous in Nineteenth-Century Britain (London: Anthem Press, 2003).

Elliot, Dorice Williams. Transported to Botany Bay: Class, National Identity, and the Literary Figure of the Australian Convict (Athens, OH: Ohio University Press, 2019).

Fairburn, Miles. The Ideal Society and its Enemies: The Foundations of Modern New Zealand Society 1850-1900 (Auckland: Auckland University Press, 1989).

Foucault, Michel. Discipline and Punish: The Birth of the Prison, trans. Alan Sheridan (London: Penguin Books, 1977. First published in 1975). 
Gollan, Robin. Radical and Working Class Politics: A Study of Eastern Australia, 1850-1910 (Parkville: Melbourne University Press, 1960).

Gordon, Eleanor and Gwyneth Nair. Murder and Morality in Victorian Britain: The Story of Madeleine Smith (Manchester: Manchester University Press, 2010).

Grass, Sean. The Commodification of Identity in Victorian Narrative (Cambridge: Cambridge University Press, 2019).

Griffiths, Andrew. The New Journalism, the New Imperialism and the Fiction of Empire, 1870-1900 (Basingstoke: Palgrave Macmillan, 2015).

Hall, Catherine. Civilising Subjects: Metropole and Colony in the English Imagination, 1830-1867 (Cambridge: Polity Press, 2002).

Hunt, Peter. The Madeleine Smith Affair (London: Carroll \& Nicholson, 1950).

Hunter, Kate. Hunting: A New Zealand History (Auckland: Random House New Zealand, 2009).

Hutchinson, Sam, Settlers, War, and Empire in the Press: Unsettling News in Australia and Britain, 1863-1902 (Cham: Palgrave Macmillan, 2018).

Jackson, Stephen. Religious Education and the Anglo-World: The Impact of Empire, Britishness, and Decolonisation in Australia, Canada, and New Zealand (Leiden; Boston: Brill, 2020).

Jenkins, Brian. Madeleine Smith on Trial: A Glasgow Murder and the Young Woman Too Respectable to Convict (North Carolina: McFarland \& Company, Inc., 2019).

Jesse, F. Tennyson, (ed.). Trial of Madeleine Smith (Sydney, Wellington, and Calcutta: Butterworth \& Co. (Australia), Limited, 1927).

Kirkpatrick, Rod. Country Conscience: A History of the New South Wales Provincial Press, 1841-1995 (Canberra City: Infinite Harvest Publishing Pty Ltd, 2000).

Knelman, Judith. Twisting the Wind: The Murderess and the English Press (Toronto, Buffalo, and London: University of Toronto Press, 1998).

Knox, William W. J. The Lives of Scottish Women: Women and Scottish Society 1800-1980 (Edinburgh: Edinburgh University Press, 2006).

Laidlaw, Zoë. Colonial Connections, 1815-1845: Patronage, the Information Revolution and Colonial Government (Manchester; New York, NY: Manchester University Press, 2005).

Lenihan, Rebecca. From Alba to Aotearoa: Profiling New Zealand's Scots migrants, 1840 1920 (Dunedin: Otago University Press, 2015),

MacGowan, Douglas. The Strange Affair of Madeleine Smith: Victorian Scotland's Trial of the Century (Edinburgh: Mercat Press, 2007).

McKenzie, Kirsten. Scandal in the Colonies (Melbourne: Melbourne University Press, 2005).

McKenzie, Kirsten. A Swindler's Progress: Nobles and Convicts in the Age of Liberty (Sydney: New South Wales Press Ltd, 2009). 
McWilliam, Rohan. Popular Politics in Nineteenth-Century England (London; New York: Routledge, 1998).

McWilliam, Rohan. The Tichborne Claimant: A Victorian Sensation (London: Hambledon Continuum, 2007).

Melman, Billie. The Culture of History: English Uses of the Past 1800-1953 (Oxford: Oxford University Press, 2006).

Morgan, Patrick. Folie a Deux: William and Caroline Dexter in Colonial Australia (Quakers Hill: Quakers Hill Press, 1999).

Morrison, Elizabeth. Engines of Influence: Newspapers of Country Victoria, 1840-1890 (Melbourne: Melbourne University Press, 2005).

Myers, Janet C. Antipodal England: Emigration and Portable Domesticity in the Victorian Imagination (Albany: State University of New York Press, 2009).

O’Hara, John. A Mug's Game: A History of Gaming and Betting in Australia (Kensington: New South Wales University Press, 1988).

Paternoster, Henry. Reimagining Class in Australia: Marxism, Populism and Social Science (Cham: Palgrave Macmillan, 2017).

Patterson, Brad, Tom Brooking, Jim McAloon, Rebecca Lenihan, and Tanja Bueltmann. Unpacking the Kists: The Scots in New Zealand (Montreal \& Kingston: McGillQueen's University Press, 2013).

Pilbeam, Pamela. Madame Tussaud and the History of Waxworks (London: Hambledon Continuum, 2006. First published in 2003).

Plotz, John. Portable Property: Victorian Culture on the Move (Princeton: Princeton University Press, 2008).

Potter, Simon. News and the British World: The Emergence of an Imperial Press System (Oxford: Oxford University Press, 2003).

Prentis, Malcolm. The Scots in Australia: A Study of New South Wales, Victoria, and Queensland, 1788-1900 (Sydney: Sydney University Press, 1983).

Radford, Andrew. Victorian Sensation Fiction (Basingstoke: Palgrave Macmillan, 2009).

Roe, Michael. Kenealy and the Tichborne Cause: A Study in Mid-Victorian Populism (Melbourne: Melbourne University Press, 1974).

Rowland, John. A Century of Murder (London: Home and Van Thal, 1950).

Rubery, Matthew. The Novelty of Newspapers: Victorian Fiction after the Invention of the News (Oxford: Oxford University Press, 2009).

Russell, Penny. Savage or Civilised? Manners in Colonial Australia (Sydney: NewSouth, 2010).

Schaffer, Kay. Women and the Bush: Forces of Desire in the Australian Cultural Tradition (Cambridge: Cambridge University Press, 1988).

Seal, Lizzie. Women, Murder and Femininity: Gender Representations of Women Who Kill (Basingstoke: Palgrave Macmillan, 2010). 
Searle, Geoffrey Russell. Morality and the Market in Victorian Britain (Oxford: Clarendon Press, 1998).

Secord, James A. Victorian Sensation: The Extraordinary Publication, Reception, and Secret Authorship of Vestiges of the Natural History of Creation (Chicago and London: University of Chicago Press, 2000).

Seymour, Mark. Emotional Arenas: Life, Love, and Death in 1870s Italy (Oxford: Oxford University Press, 2020).

Shrimpton, Nicholas (ed.). Anthony Trollope: An Autobiography and Other Writings (Oxford: Oxford University Press, 2014).

Smart, Carol. Women, Crime and Criminology: A Feminist Critique (London: Routledge \& Kegan Paul, 1977).

Smith, A. Duncan (ed.). The Trial of Madeleine Smith (Sydney and Wellington: Butterworth \& Co. (Australia), Limited, 1921. First published in 1905).

Stern, Rebecca. Home Economics: Domestic Fraud in Victorian England (Columbus: Ohio State University Press, 2008).

Thomas, David Wayne. Cultivating Victorians: Liberal Culture and the Aesthetic (Philadelphia: University of Pennsylvania Press, 2004).

Tosh, John. Manliness and Masculinities in Nineteenth-Century Britain (Harlow: Pearson Education Limited, 2005).

Trainor, Luke. British Imperialism and Australian Nationalism: Manipulation, Conflict and Compromise in the Late Nineteenth Century (Cambridge: Cambridge University Press, 1994).

Wallace, Valerie. Scottish Presbyterianism and Settler Colonial Politics: Empire of Dissent (Cham: Palgrave Macmillan, 2018).

Walsh, Bridget. Domestic Murder in Nineteenth-Century England: Literary and Cultural Representations (Surrey, UK and Burlington, US: Ashgate, 2014).

Ward, Ian. Sex, Crime and Literature in Victorian England (London: Hart Publishing Ltd., 2014).

Whorton, James C. How Victorian Britain was Poisoned at Home, Work, and Play (Oxford: Oxford University Press, 2010).

Wiener, Martin J. Reconstructing the criminal: culture, law, and policy in England, 1830 1914 (Cambridge: Cambridge University Press, 1990).

Wiener, Martin J. An Empire on Trial: Race, Murder, and Justice under British Rule, 1870 1935 (Cambridge: Cambridge University Press, 2009).

Wilkie, Benjamin. The Scots in Australia, 1788-1938 (Woolbridge: Boydell Press, 2017).

Wilson, John Gray. Not Proven (London: Secker \& Warburg, 1960).

Woodruff, Douglas. The Tichborne Claimant: A Victorian Mystery (London: Hollis and Carter, 1957).

Woollacott, Angela. Gender and Empire (Basingstoke: Palgrave Macmillan, 2006). 


\section{Chapters from Edited Collections}

Bayly, C. A. 'Informing Empire and Nation: Publicity, Propaganda and the Press, 18801920', in Hiram Morgan (ed.), Information, Media and Power Through the Ages (Dublin: University College Dublin Press, 2001), pp.179-201.

Becker, Peter. 'Researching Crime and Criminals in the 19th Century' in Ruth Ann Triplett (ed.), The Handbook of the History and Philosophy of Criminology (Hoboken: John Wiley \& Sons, Inc., 2018), pp.32-47.

Colligan, Mimi, and Veronica Kelly, 'George Fawcett', in Philip Parsons and Victoria Chance (eds.), Companion to Theatre in Australia (Sydney: Currency Press, 1995), p.222.

Darian-Smith, Kate. 'Images of Empire: Gender and Nationhood in Australia at the Time of Federation', in Kate Darian-Smith, Patricia Grimshaw, and Stuart Macintyre (eds.), Britishness Abroad: Transnational Movements and Imperial Cultures (Carlton: Melbourne University Press, 2007), pp.153-168.

Farmer, Lindsay. 'Orton, Arthur', in Peter Cane and Joanne Conaghan (eds.), The New Oxford Companion to Law (Oxford: Oxford University Press, 2008), p.855.

Hall, Catherine, Keith McClelland, and Jane Rendall. 'Introduction', in Catherine Hall, Keith McClelland, and Jane Rendall (eds.), Defining the Victorian Nation: Class, Race, Gender, and the British Reform Act of 1867 (Cambridge: Cambridge University Press, 2000), pp.1-70.

Hall, Catherine, and Sonya O. Rose. 'Introduction: being at home with the Empire', in Catherine Hall and Sonya O. Rose (eds.), At Home with the Empire: Metropolitan culture and the Imperial World (New York, NY: Cambridge University Press, 2006), pp.1-31.

Jesse, F. Tennyson. 'Madeleine Smith', in Harry Hodge (ed.), Famous Trials: Volume I (Middlesex and New York: Penguin Books, 1941), pp.9-48.

Laube, Anthony. 'Adelaide, Sensationalism and the Development of New Journalism in the Early History of the South Australian Press', in Alberto Gabriele (ed.), Sensationalism and the Genealogy of Modernity: A Global Nineteenth-Century Perspective (New York: Palgrave Macmillan, 2017), pp.69-94.

McLeod, Aorewa. 'Ellen Ellis, 1829-1895', in Charlotte Macdonald, Merimeri Penfold, and Bridget Williams (eds.), The Book of New Zealand Women / Ko Kui Ma Te Kaupapa (Wellington: Bridget Williams Books, 1991), pp.208-210.

McClelland, Keith. 'Rational and Respectable Men: Gender, the Working Class, and Citizenship in Britain, 1850-1867', in Laura L. Frader and Sonya O. Rose (eds.), Gender and Class in Modern Europe (Ithaca and London: Cornell University Press, 1996), pp.280-293.

McGowen, Randall. 'The Death Penalty', in Paul Knepper and Anja Johansen (eds.), The Oxford Handbook of The History of Crime and Criminal Justice (Oxford: Oxford University Press, 2016), pp.615-634. 
Morrison, Elizabeth. 'Serial fiction in Australian colonial newspapers', in John O. Jordan and Robert L. Patten (eds.), Literature in the Marketplace: Nineteenth-century British publishing and reading practices (Cambridge: Cambridge University Press, 1995), pp.306-324.

Morrison, Elizabeth. 'Grub Street Inventor: James Harrison's Journalism, Old and New, in Geelong, Melbourne and London', in Denis Cryle (ed.), Disreputable Profession: Journalists and Journalism in Colonial Australia (Rockhampton: Central Queensland University Press, 1997), pp.55-77.

Nalbach, Alex. "“The Software of Empire": Telegraphic News Agencies and Imperial Publicity, 1865-1914', in Julie F. Codell (ed.), Imperial Co-Histories: National Identities and the British and Colonial Press (Madison: Fairleigh Dickinson University Press, 2003), pp.68-94.

Parsons, Joanne Ella. 'Fosco's Fat: Transgressive Consumption and Bodily Control in Wilkie Collins' The Woman in White', in Joanne Ella Parsons and Ruth Heholt (eds.), The Victorian Male Body (Edinburgh: Edinburgh University Press, 2018), pp.215-233.

Robb, George and Nancy Erber. 'Introduction', in George Robb and Nancy Erber (eds.), Disorder in the Court: Trials and Sexual Conflict at the Turn of the Century (Basingstoke and London: Macmillan Press, 1999), pp.1-12.

Roe, Michael. 'Foreword: Australia and the Tichborne Case', in Hugh Anderson (ed.). Baronet or Butcher? The Trials of the Tichborne Claimant (Victoria: Red Rooster Press, 1999), pp.vii-xi.

Rowbotham, Judith and Kim Stevenson. 'Causing a Sensation: Media and Legal Representations of Bad Behaviour', in Judith Rowbatham and Kim Stevenson (eds.), Behaving Badly: Social Panic and Moral Outrage - Victorian and Modern Parallels (Hampshire and Burlington: Ashgate, 2003), pp.31-46.

Scholl, Lesa. 'Ubiquitous Theft: The Consumption of London in Mayhew's Underworld', in Grace Moore and Michelle J. Smith (eds.), Victorian Environments: Acclimatizing to Change in British Domestic and Colonial Culture (London: Palgrave Macmillan, 2018), pp.79-96.

Shannon, Mary L. 'Colonial Networks and the Periodical Marketplace', in Joanne Shattock (ed.), Journalism and the Periodical Press in Nineteenth-Century Britain (Cambridge: Cambridge University Press, 2017), pp.203-223.

Stoler, Ann Laura. 'Cultivating bourgeois bodies and racial selves', in Catherine Hall (ed.), Cultures of Empire (New York: Routledge, 2000), pp.87-119.

Sutter, Gavin. 'Penny Dreadfuls and Perverse Domains: Victorian and Modern Moral Panics', in Judith Rowbotham and Kim Stevenson (eds.), Behaving Badly: Social Panic and Moral Outrage - Victorian and Modern Parallels (Hampshire and Burlington: Ashgate, 2003), pp.159-175.

Ward, Stuart. 'Imperial Identities Abroad', in Sarah Stockwell (ed.), The British Empire: Themes and Perspectives (Malden, Oxford, and Calrton: Blackwell Publishing Ltd., 2008), pp.219-243. 
Webby, Elizabeth. 'Australia', in J. Don Vann and Rosemary VanArsdel (eds.), Periodicals of Queen Victoria's Empire: An Exploration (Toronto: University of Toronto Press, 1996), pp.19-58.

\section{Journal Articles}

Barclay, Katie. 'Marriage, Sex, and the Church of Scotland: Exploring Non-Conformity Amongst the Lower Orders', Journal of Religious History, Vol. 43, no. 2, June 2019, pp.163-179.

Barrie, David G. 'Naming and Shaming: Trial by Media in Nineteenth-Century Scotland', Journal of British Studies, Vol. 54, April 2015, pp.349-376.

Bray, Samuel. 'Not Proven: Introducing a Third Verdict', The University of Chicago Law Review, Vol. 72, no. 4, 2005, pp.1299-1329.

Casey, Christopher A. 'Common Misperceptions: The Press and Victorian Views of Crime', Journal of Interdisciplinary History, Vol. 41, no. 3, 2011, pp.367-391.

Colligan, Mimi. 'Waxworks shows and some of their proprietors in Australia, 1850s-1910s', Australasian Drama Studies, No. 34, April 1999, pp.86-107.

Connell, R. W. 'Wagga's Butcher, Tichborne's Claimant, Kenealy's Cause', Meanjin Quarterly, Vol. 34, no. 1, 1975, pp.100-103.

Cumming, Cliff. 'Scottish National Identity in an Australian Colony', The Scottish Historical Review, Vol. 72, no. 193, 1993, pp.22-38.

Davies, Graham M. 'Identification of Familiar Faces after Long Intervals: The Tichborne Claimant Revisited', Applied Cognitive Psychology, Vol. 30, 2016, pp.484-489.

Dawson, Cassie. “"The Slaughterman of Wagga Wagga”, Imposture, National Identity, and the Tichborne Affair', Australian Literary Studies, Vol. 21, no. 4, 2004, pp.1-13.

Donnelly, Tiffany. 'Trumpery Stuff': Gender Politics in Australian Publishing, 1858', Bibliographical Society of Australia and New Zealand Bulletin, Vol. 26, no. 1, 2002, pp.29-42.

Duff, Peter. 'The Scottish Criminal Jury: A Very Peculiar Institution', Law and Contemporary Problems, Vol. 62, no. 2, 1999, pp.173-201.

Erickson, Arvel B., and Fr. John R. McCarthy, 'The Yelverton Case: Civil Legislation and Marriage', Victorian Studies, Vol. 14, no. 3, March 1971, pp.275-291.

Everest-Phillips, Max. 'The 1871 'Tichborne Claimant' medal and the forging of Australia's identity', Journal of the Numismatic Association of Australia, Vol. 24, 2013, pp.121.

Farmer, Lindsay. 'With all the Impressiveness and Substantial Value of Truth': Notable Trials and Criminal Justice, 1750-1930', Law and Humanities, Vol. 1, no. 1, 2007, pp.57-78.

Gill, Rebecca. 'The Imperial Anxieties of a Nineteenth-Century Bigamy Case', History Workshop Journal, Vol. 57, 2004, pp.58-78. 
Godfrey, Barry, Stephen Farrall, and Susanne Karstedt, 'Explaining Gendered Sentencing Patterns for Violent Men and Women in the Late-Victorian and Edwardian Period', British Journal of Criminology, Vol. 45, no. 5, 2005, pp.696-720.

Gordon, Eleanor, and Gwyneth Nair, 'The economic role of middle-class women in Victorian Glasgow', Women's History Review, Vol. 9, no. 4, 2000, pp.791-814.

Gribling, Barbara. "A Visit to Madame Tussaud's": Capturing a Child Audience in Victorian and Edwardian England", Journal of the History of Childhood and Youth, Vol. 11, no. 3,2018 , pp.421-438.

Harling, Philip. 'The Trouble with Convicts: From Transportation to Penal Servitude, 184067', Journal of British Studies, Vol. 53, No. 1, 2014, pp.80-110.

Hartman, Mary S. 'Murder for Respectability: The Case of Madeleine Smith', Victorian Studies, Vol. 16, no. 4, 1973, pp.381-400.

Harvey, Ross. 'Bringing the News to New Zealand: The supply and control of overseas news in the nineteenth century', Media History, Vol. 8, no. 1, 2002, pp.21-34.

Helfield, Randa. 'Female Poisoners of the Nineteenth Century: A Study of Gender Bias in the Application of the Law', Osgoode Hall Law Journal, Vol. 28, no. 1, 1990, pp.53101.

Helfield, Randa. 'Poisonous Plots: Women Sensation Novelists and Murderesses of the Victorian Period', Victorian Review, Vol. 21, no. 2, 1995, pp.161-188.

Kain, Jennifer. 'The Ne'er-do-well: Representing the Dysfunctional Migrant Mind, New Zealand 1850-1910', Studies in the Literary Imagination, Vol. 48, no. 1, 2015, pp.75-92.

Kent, Christopher. 'Victorian Self-Making, or Self-Unmaking? The Tichborne Claimant Revisited', Victorian Review, Vol. 17, no. 1, 1991, pp.18-34.

Kiehna, Lauren Harmsen. 'Sensation and the Fourth Estate: "The Times" and the Yelverton Bigamy Trials', Victorian Periodicals Review, Vol. 7, no. 1, 2014, pp.87-104.

Kukulies-Smith, Wendy, and Susan Priest. "No Hope of Mercy" for the Borgia of Botany Bay: Louisa May Collins, The Last Woman Executed in NSW, 1889', Canberra Law Review, Vol. 10, no. 2, 2011, pp.144-158.

Leneman, Leah. 'Seduction in Eighteenth and Early Nineteenth-Century Scotland', The Scottish Historical Review, Vol. 78, no. 205, April 1999, pp.39-59.

Lumsden, Joy. 'The True and Remarkable History of Andrew Bogle', Jamaican Historical Society Bulletin, Vol. 11, no 4, pp.34-43.

MacEachen, Douglas B. 'Wilkie Collins and British Law', Nineteenth-Century Fiction, Vol. 5, no.2, 1950, pp.121-139.

McGregor, Russell. 'The necessity of Britishness: ethno-cultural roots of Australian nationalism', Nations and Nationalism, Vol. 12, no. 3, 2006, pp.493-511.

McKibbin, Ross. 'Working-Class Gambling in Britain 1880-1939', Past \& Present, no. 82, 1979, pp.147-178.

McWilliam, Rohan. 'Liberalism Lite?', Victorian Studies, Vol. 48, no. 1, 2005, pp. 103-111. 
Menzies, Isa. 'Horses Down Under: The Underdog Schematic Narrative Template and Australian Nationalism', Journal of Australian Studies, Vol. 45, no. 1, 2021, pp.1832.

Moffat, Kirstine. 'The Demon Drink: Prohibition Novels 1882-1924', Journal of New Zealand Literature, Vol. 23, no. 1, 2005, pp.139-161.

Murphy, Sara. 'Inadmissible Evidence: The Trials of Madeleine Smith and Collins's The Law and the Lady', Victorian Literature and Culture, Vol. 44, no. 1, 2016, pp.163-188.

Murphy, Sara. "No Two Men Were Ever Alike Within": The Tichborne Trial, The Lord Chief Justice, and The Narration of Identity', Law, Culture and the Humanities, Vol. 13, no. 2, 2017, pp.244-260.

Nora, Pierre. 'Between Memory and History: les lieux de memoire', Representations, No. 26, 1989, pp.7-24.

Parry, J. P. 'The Impact of Napoleon III on British Politics, 1851-1880', Transactions of the Royal Historical Society, Vol. 11, 2001, pp.147-175.

Paternoster, Henry. 'Questioning the Legacy of Class Structure in Australian History: An Australian "Historical” Class Analysis?', Labour History, no. 111, 2016, pp.99-120.

Pilbeam, Pamela. 'Madame Tussaud and the business of Wax: Marketing to the Middle Classes', Business History, Vol. 45, no. 1, 2003, pp.6-22.

Pluskota, Marion. 'Petty Criminality, Gender Bias, and Judicial Practice in NineteenthCentury Europe', Journal of Social History, Vol. 51, no. 4, 2018, pp.717-735.

Schaffer, Kay. 'Women and the Bush: Australian National Identity and Representations of the Feminine', Antipodes, 1989, Vol. 3, no. 1, 1989, pp.7-13.

Sturma, Michael. 'Crime News in Colonial New South Wales', Media Information Australia, Vol. 32, no. 1, 1984, pp.7-13.

Sullivan, Sheila. “"What is the Matter with Mary Jane?”: Madeleine Smith, Legal Ambiguity, and the Gendered Aesthetic of Victorian Criminality', Genders, Vol. 35, 2002, pp.144.

Wagner, Tamara S. 'The domestic novel's antipodes: false heirs and reclaimed returnees in Charlotte Yonge's My Young Alcides', Journal of Australian Studies, Vol. 35, no. 3, 2011, pp.317-334.

Warrington, Lisa. 'We are amused: Theatre comes to Dunedin, December 1861 - April 1862', Australasian Drama Studies, 2013, Vol. 62, pp.41-54.

Wilkie, Ben. 'Scottish Identity in Stone: Statues of Robert Burns and William Wallace in Ballarat', Victorian Historical Journal, Vol. 84, no. 2, 2013, pp.279-302.

Wix, Kathryn. 'The Second Reform Act and the Problem of Electoral Corruption', Parliamentary History, Vol. 36, no. 1, 2017, pp.64-81.

Yan, Shu-Chuan. 'Emotions, Sensations, and Victorian Working-Class Readers', The Journal of Popular Culture, Vol. 50, no. 2, pp.317-340. 


\section{Magazine Articles}

Dexter, Nancy. 'Wagga Wagga and the Tichborne Case', Walkabout, Vol. 32, no. 8, 1966, pp.19-21.

Higham, Charles. 'The Saga of Madeleine Smith', Bulletin, 9 July 1966, p.39.

'Revelations of a Non-Proven Murder Case After Seventy Years', Australian Women's Mirror, Vol. 29, no. 8, 14 January 1953, pp.3, 13.

'Society', The Bulletin, 27 June 1928, p.11.

\section{Conference Papers}

Wallace, Valerie. 'Scots law and British settler colonialism: the debate on criminal procedure in nineteenth-century New Zealand' (paper presented at the Australian and New Zealand Law and History Society Conference, University of Auckland, Auckland, 9 December 2020), unpublished paper.

\section{Theses}

Blackburn, Maggie. 'Entertaining Prospects: Garrison and Gold Field Theatre in 19thCentury New Zealand circa 1850-1870', MA Thesis, Victoria University of Wellington, 2021.

Eutsey, Lisa. 'The Rhetoric of Empire and the Fiction of Anthony Trollope', PhD Thesis, Pennsylvania State University, 2009.

\section{Internet Sources}

Chenery, Susan. 'They'll never hang a woman': Louisa Collins thought she'd be spared', The Guardian, https://www.theguardian.com/books/2018/sep/25/theyll-never-hang-awoman-louisa-collins-thought-shed-be-spared, accessed 23 July 2020.

Glowrey, Cheryl. 'McMillan, Angus (1810-1865)', Australian Dictionary of Biography, National Centre of Biography, Australian National University, https://adb.anu.edu.au/biography/mcmillan-angus-2416, published online 2017, accessed 13 April 2021.

'Immigration History from Scotland to Victoria', Museums Victoria, https://origins.museumsvictoria.com.au/countries/scotland/, accessed 4 December 2020.

Moncur, Doug. 'Madeleine Smith as a worldwide phenomenon', stuff 'n other stuff (blog), 6 May 2017, https://moncurdg.com/2017/05/06/madeleine-smith-as-a-worldwidephenomenon/.

Moncur, Doug. 'Melbourne gets the news first', stuff ' $n$ other stuff (blog), 14 June 2017, https://moncurdg.com/2017/06/14/melbourne-gets-the-news-first/.

Moncur, Doug. 'Madeleine Smith in Australia (not)', stuff ' $n$ other stuff (blog), 8 August 2020, https://moncurdg.com/2020/08/08/madeleine-smith-in-australia-not/. 
Penzig, Edgar F. 'Gardiner, Francis (Frank) (1830-1903)', Australian Dictionary of Biography, National Centre of Biography, Australian National University, http://adb.anu.edu.au/biography/gardiner-francis-frank-3589/text5561, published first in hardcopy 1972, accessed 11 January 2021.

Ryan, J. S. 'Dexter, Caroline (1819-1884)', Australian Dictionary of Biography, National Centre of Biography, Australian National University, http://adb.anu.edu.au/biography/dexter-caroline-3407/text5173, published first in hardcopy 1972, accessed 21 December 2020.

Sayers, C. E. 'Syme, Ebenezer (1825-1860)', Australian Dictionary of Biography, National Centre of Biography, Australian National University, http://adb.anu.edu.au/biography/syme-ebenezer-4680/text7743, published first in hardcopy 1976, accessed 7 December 2020.

'Second Reform Act 1867', UK Parliament, https://www.parliament.uk/about/livingheritage/evolutionofparliament/houseofcommons/reformacts/overview/furtherreform acts/, accessed 2 February 2021.

Serle, Geoffrey. 'Wilson, Edward (1813-1878)', Australian Dictionary of Biography, National Centre of Biography, Australian National University, http://adb.anu.edu.au/biography/wilson-edward-4866/text8131, published first in hardcopy 1976, accessed 11 January 2021.

'The Greatest Impostor in History: Souvenir figurines of the Tichborne Trials', Museum of the Riverina, https://museumriverina.com.au/collections/highlights/the-greatestimpostor-in-history\#.YK2cDqgzaUk, accessed 26 May 2021.

'The Waxworks', National Portrait Gallery, https://www.portrait.gov.au/content/-556, accessed 8 December 2020.

'Tichborne carte de visite', Museum of the Riverina, https://museumriverina.com.au/collections/highlights/tichborne-carte-devisite\#.YK2cDagzaUk, accessed 26 May 2021.

Wilson, John. 'Scots - 1853-1870: a surge of Scots', Te Ara - the Encyclopedia of New Zealand, http://www.TeAra.govt.nz/en/scots/page-4, accessed 9 May 2020.

Woods, Carole. 'Haddon, Frederick William (1839-1906)', Australian Dictionary of Biography, National Centre of Biography, Australian National University, https://adb.anu.edu.au/biography/haddon-frederick-william-3686/text5763, published first in hardcopy 1972, accessed 13 April 2021. 